US Arn iy Corps

-ngıneers

LIBRARY ;rways Experiment

USE ONLY on

\title{
Statistical Analysis and Variability of Pavement Materials
}

\author{
by Reed B. Freeman, William P. Grogan
}

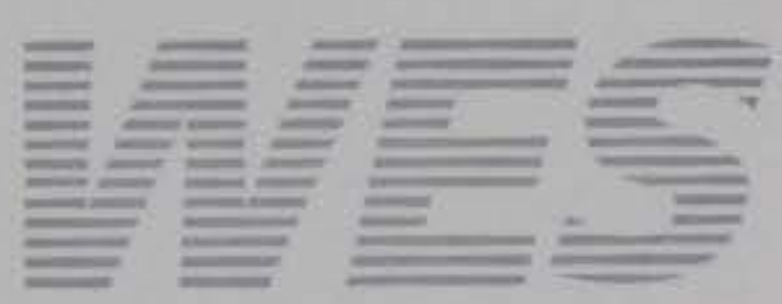

Approved For Public Release; Distribution Is Unlimited

Research Library

US Army Encino.." "aterways

Experiment siation

"sburg. Mississippi 


\section{Statistical Analysis and Variability of Pavement Materials}

by Reed B. Freeman, William P. Grogan

U.S. Army Corps of Engineers

Waterways Experiment Station

3909 Halls Ferry Road

Vicksburg, MS 39180-6199

Final report

Approved for public release; distribution is unlimited 


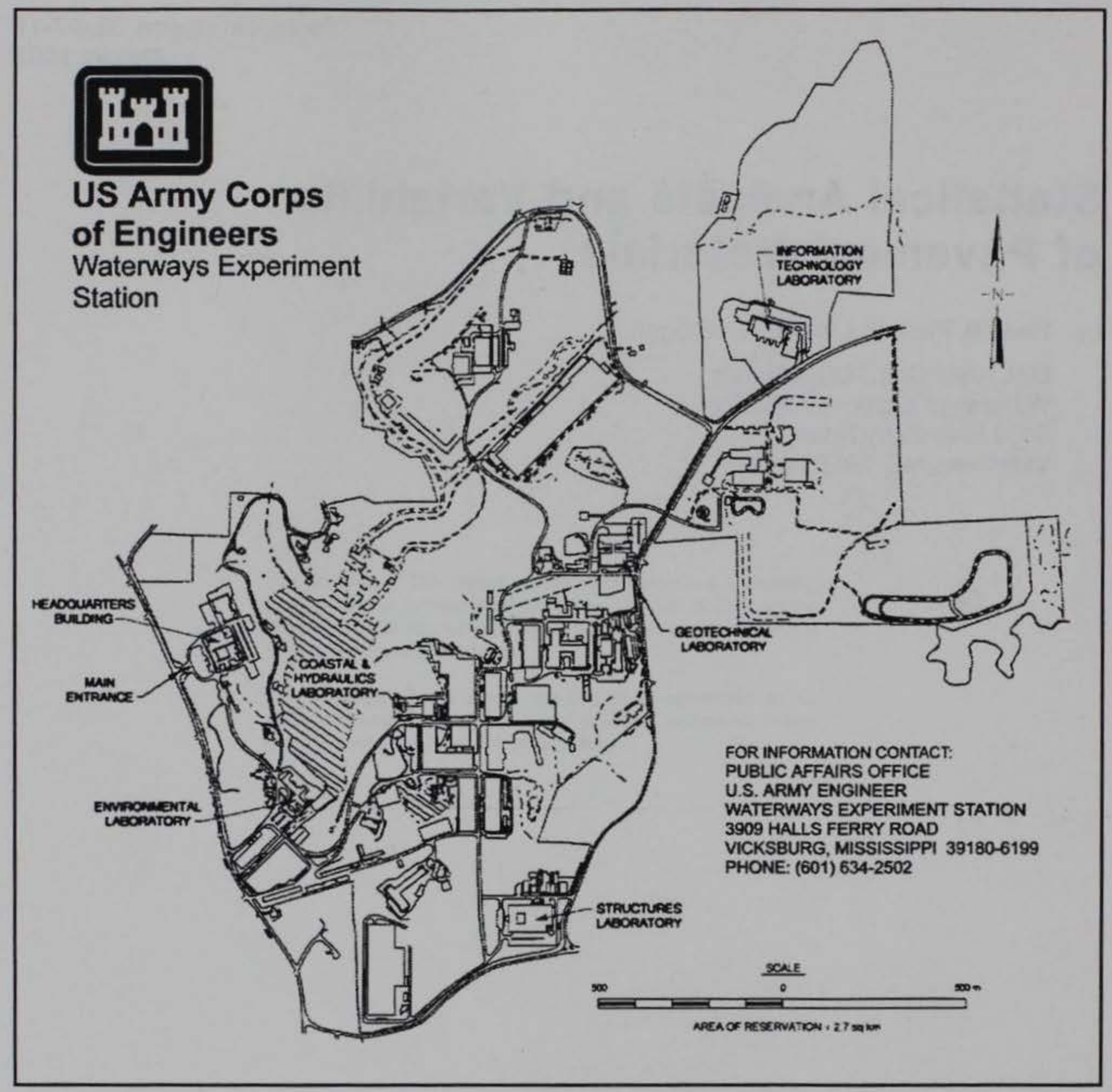

Waterways Experiment Station Cataloging-in-Publication Data

Freeman, Reed B.

Statistical analysis and variability of pavement materials / by Reed B. Freeman, William P. Grogan ; prepared for U.S. Army Corps of Engineers.

170 p. : ill. ; $28 \mathrm{~cm}$. - (Technical report ; GL-97-12)

Includes bibliographic references.

1. Road materials - Analysis - Statistical methods. 2. Pavements - Analysis. 3. Analysis of variance. I. Grogan, William P. II. United States. Army. Corps of Engineers. III. U.S. Army Engineer Waterways Experiment Station. IV. Geotechnical Laboratory (U.S. Army Engineer Waterways Experiment Station) V. Title. VI. Series: Technical report (U.S. Army Engineer Waterways Experiment Station) ; GL-97-12.

TA7 W34 no.GL-97-12 


\section{Contents}

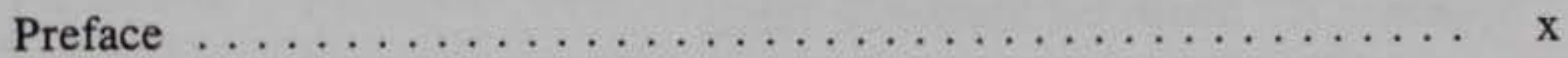

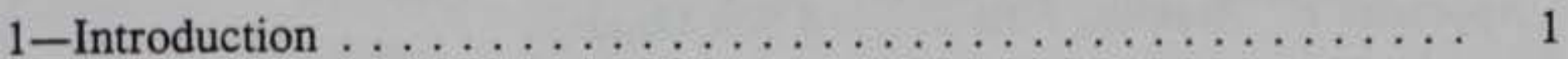

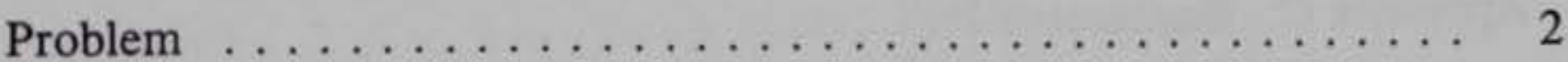

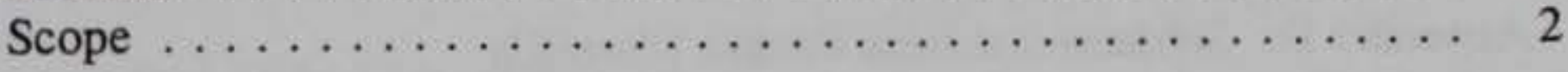

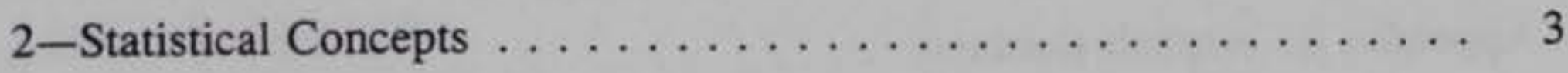

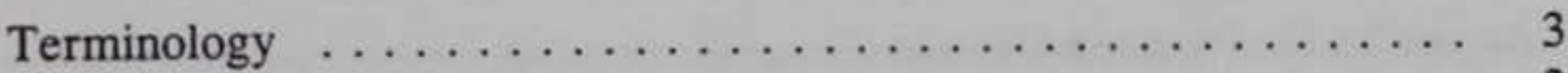

Population versus sample $\ldots \ldots \ldots \ldots \ldots \ldots \ldots \ldots \ldots, 3$

Unit, observation, and variable $\ldots \ldots \ldots \ldots \ldots \ldots \ldots \ldots$

Types of variables ..................... 4

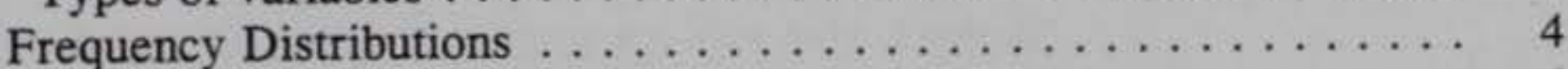

Numerical Descriptive Statistics . . . . . . . . . . . . . . 6

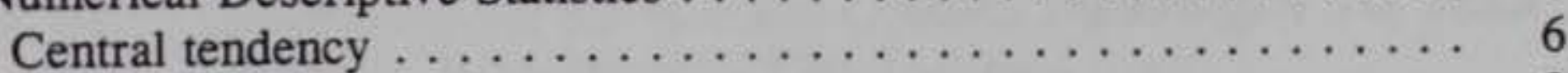

Dispersion . . . . . . . . . . . . . . . . 8

Shape $\ldots \ldots \ldots \ldots \ldots \ldots \ldots \ldots \ldots \ldots \ldots \ldots \ldots \ldots \ldots \ldots \ldots \ldots$

Discrete Probability Distributions $\ldots \ldots \ldots \ldots \ldots \ldots \ldots \ldots .11$

Binomial distribution $\ldots \ldots \ldots \ldots \ldots \ldots \ldots \ldots \ldots \ldots \ldots \ldots$

Continuous Probability Distributions . . . . . . . . . . . 14

Normal distribution $\ldots \ldots \ldots \ldots \ldots \ldots \ldots \ldots \ldots \ldots$

Standard normal distribution $\ldots \ldots \ldots \ldots \ldots \ldots \ldots \ldots \ldots$

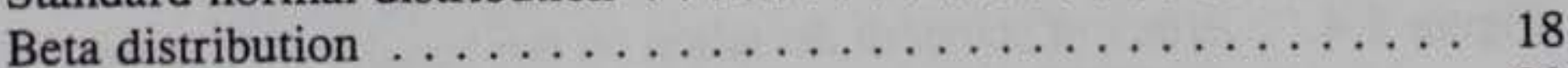

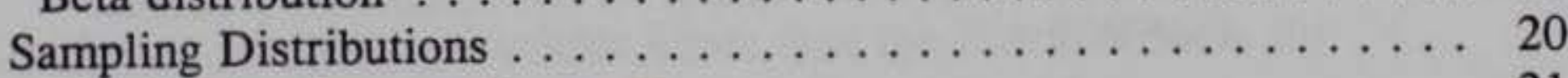

Distribution for sample means $\ldots \ldots \ldots \ldots \ldots \ldots \ldots \ldots, 21$

Distribution for sample variances . . . . . . . . . . . 23

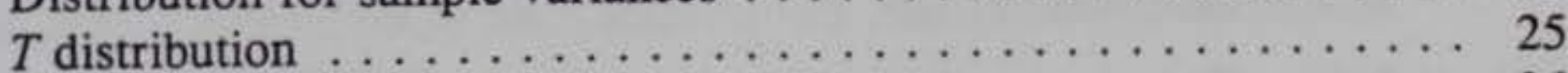

Chi-squared $\left(\mathrm{X}^{2}\right)$ distribution $\ldots \ldots \ldots \ldots \ldots \ldots \ldots \ldots \ldots \ldots \ldots \ldots \ldots$

$F$ distribution . . . . . . . . . . . . . . . 29

3-Analyzing Pavement Materials Data $\ldots \ldots \ldots \ldots \ldots \ldots \ldots, 33$

Distribution Shapes . . . . . . . . . . . . . . 33

Departures from Normality $\ldots \ldots \ldots \ldots \ldots \ldots \ldots \ldots \ldots \ldots$

Tests for Normality $\ldots \ldots \ldots \ldots \ldots \ldots \ldots \ldots \ldots \ldots \ldots \ldots \ldots$

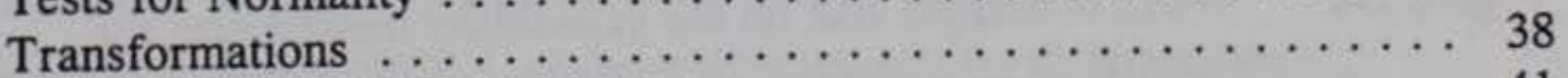

Handling Potential Outliers $\ldots \ldots \ldots \ldots \ldots \ldots \ldots \ldots \ldots \ldots$

Components of Variability $\ldots \ldots \ldots \ldots \ldots \ldots \ldots \ldots \ldots$

Round robin studies $\ldots \ldots \ldots \ldots \ldots \ldots \ldots \ldots \ldots \ldots \ldots$

Construction site studies $\ldots \ldots \ldots \ldots \ldots \ldots \ldots \ldots \ldots \ldots$ 
4-Historical Variability Data $\ldots \ldots \ldots \ldots \ldots \ldots . \ldots \ldots$

Residual Fine-Grained Soil Deposits . . . . . . . . . . . . . . . 65

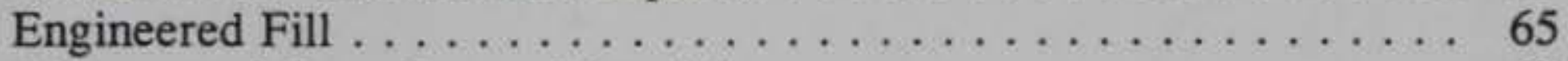

Subbase and Base Course Materials . . . . . . . . . . . . . . 68

Asphalt Concrete $\ldots \ldots \ldots \ldots \ldots \ldots \ldots \ldots \ldots \ldots \ldots \ldots$

Portland Cement Concrete $\ldots \ldots \ldots \ldots \ldots \ldots \ldots$. . . . . . 71

5-Summary, Conclusions, and Recommendations . . . . . . . 76

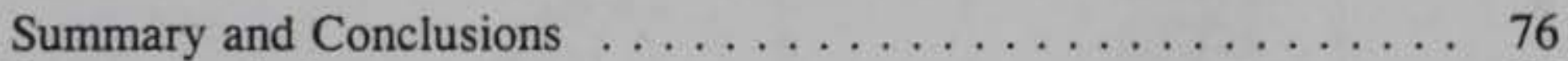

Recommendations ...................... 77

Bibliography $\ldots \ldots \ldots \ldots \ldots \ldots \ldots \ldots \ldots \ldots \ldots \ldots \ldots \ldots \ldots \ldots \ldots \ldots \ldots$

Appendix A: Statistical Reference Tables .............. A1

Appendix B: Residual Fine-Grained Soil Deposits .......... B1

Appendix C: Engineered Fill $\ldots \ldots \ldots \ldots \ldots \ldots \ldots \ldots \ldots$ C1

Appendix D: Subbase and Base Course Materials . . . . . . . . D1

Appendix E: Asphalt Concrete $\ldots \ldots \ldots \ldots \ldots \ldots \ldots \ldots$ E1

Appendix F: Portland Cement Concrete $\ldots \ldots \ldots \ldots \ldots$ F1

SF 298

\section{List of Figures}

Figure 2-1. Relative frequency distribution for soil CBR ... . . . 6

Figure 2-2. Relative frequency distribution with various skew .... 12

Figure 2-3. Discrete binomial distribution . . . . . . . . . 16

Figure 2-4. Effect of standard deviation on the breadth of a normal

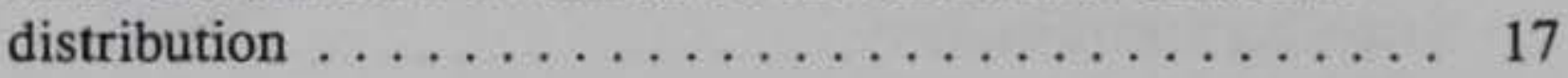

Figure 2-5. Concrete compressive strength with an assumed normal distribution .................. 19

Figure 2-6. Shapes of the beta distribution (Harr 1978) . . . . . 20

Figure 2-7. Load-transfer between pavement slabs with an assumed beta distribution . . . . . . . . . . . . . . 24

Figure 2-8. Effect of sample size on the probability distribution for sample means . . . . . . . . . . . . . 26

Figure 2-9. Effect of sample size on the probability distribution for student's $t \ldots \ldots \ldots \ldots \ldots \ldots \ldots \ldots \ldots \ldots \ldots \ldots$

Figure 2-10. Effect of sample size on the chi-square distribution . . . 30

Figure 2-11. Effect of sample sizes on the $F$ distribution . . . . . . 31 
Figure 2-12. Effect of unequal sample sizes on the $F$ distribution . . . 32

Figure 3-1. Characteristic shapes of smooth-curve approximations for frequency distributions (Spiegel 1988) . . . . . . . 34

Figure 3-2. Z-Plot for a example problem concerning the moisture content of soil . . . . . . . . . . . . . . 40

Figure 3-3. P-Plot for an example problem concerning the moisture

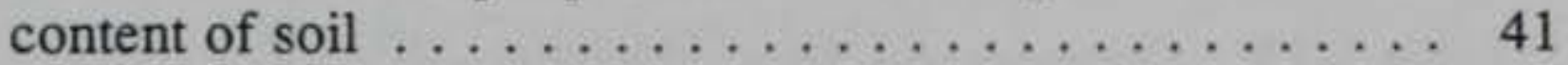

Figure 3-4. Variance components for a construction site study . . . . 43

Figure 3-5. Sampling plan for studying construction site variability .. 44

Figure 3-6. Frequency distribution for allowable aircraft passes . . . 44

Figure 3-7. Frequency distribution for transformed (log) allowable

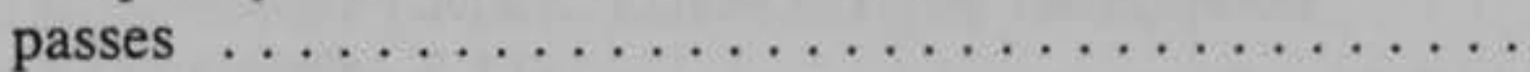

\section{List of Tables}

Table 2-1. California Bearing Ratio for a Silty Gravel . . . . . . . 5

Table 2-2 Relative Densities for Hot Mix Asphalt ......... 7

Table 3-1. Goodness-of-Fit for Moisture Contents Percent of Residuals, High-Plasticity Clay (Adapted from Steel and Torrie 1980) . . . . . . . . . . . . . . 38

Table 3-2. Z-Plot and P-Plot Calculations for Moisture Contents of Residual, High-Plasticity Clay (Adapted from Steel and Torrie 1980) . . . . . . . . . . . . . . 39

Table 3-3. Transformation of Allowable Passes Data for an Airfield Feature .................. 42

Table 3-4. Percent of Particles Finer than the No. 200 Sieve for Asphalt Concrete Aggregate . . . . . . . . . . 47

Table 3-5. Execution of the Tiejen-Moore Statistic for Determining

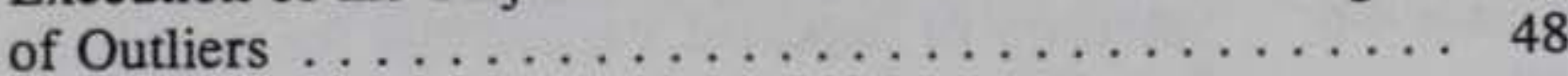

Table 3-6. Chauvenot's Criteria for Determination of Outliers (Coleman and Steel 1989) . . . . . . . . . . . . . . 49

Table 3-7. Raw Data for a Fabricated Round Robin Experiment Concerning Plasticity Index of Soils . . . . . . . 51

Table 3-8. Summary of Mean and Within-Laboratory Variance . . . . 52

Table 3-9. Round Robin Analysis of Variance for Plasticity Index Using High-Plasticity Soil . . . . . . . . . . . . 53

Table 3-10. Round Robin Analysis of Variance for Plasticity Index Using Medium-Plasticity . . . . . . . . . . . . 
Table 3-11. Round Robin Analysis of Variance for Plasticity Index Using Low-Plasticity Soil . . . . . . . . . . . . . 54

Table 3-12. Summary of Round Robin PI Data by Soil Type . . . . . 54

Table 3-13. Standard Deviations and Coefficients of Variation for PI Data . . . . . . . . . . . . . . . . . 55

Table 3-14. Precision Statement for Plasticity Index $\ldots \ldots \ldots 6$

Table 3-15. Compressive Strengths of Steam-Cured Concrete, MPa (after Brown 1966) . . . . . . . . . . . . 58

Table 3-16. Example of Computational Procedures for Variance

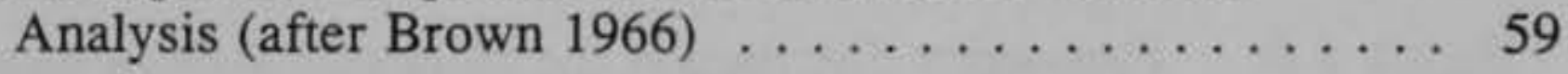

Table 3-17. Analysis of Variance for Concrete Compressive

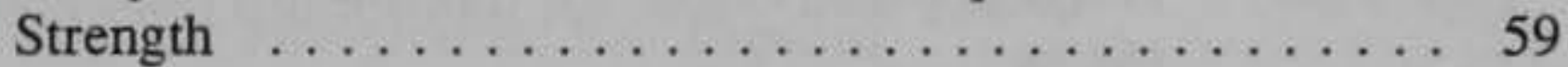

Table 3-18. Summary of ANOVA Calculation Results for Concrete Compressive Strength . . . . . . . . . . . 60

Table 3-19. Percent Passing the 19-mm Sieve (adapted from Nicotera 1974)

Table 3-20. Analysis of Variance for Percent Passing the 3/4-in.

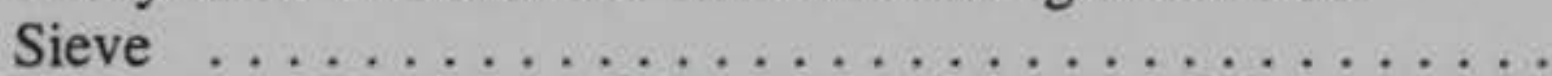

Table 3-21. Components of Variance for Percent Passing the 19-mm Sieve .................... 63

Table 4-1. Summary of Reported Variabilities for Residual Fine-Grained Soil Deposits . . . . . . . . . . . 66

Table 4-2. Summary of Reported Variabilities for Compacted Fine-Grained Soil Deposits . . . . . . . . . . . .

Table 4-3. Summary of Reported Variabilities for Lime-Soil Mixtures and Soil-Cement . . . . . . . . . . . . . .

Table 4-4. Summary of Reported Variabilities for Subbase and Base Course Materials . . . . . . . . . . . . . . . . . .

Table 4-5. Summary of Reported Variabilities for Lime- and CementStabilized Subbase and Base Course Materials . . . . . 70

Table 4-6. Summary of Reported Variabilities for Asphalt-Stabilized Base Course Materials . . . . . . . . . . . 70

Table 4-7. Summary of Reported Variabilities for Asphalt Cement . . 71

Table 4-8. Summary of Reported Variabilities for Asphalt Concrete Materials . . . . . . . . . . . . 72

Table 4-9. Summary of Reported Variabilities for Field Measurements on Asphalt Pavements ..........

Table 4-10. Summary of Reported Variabilities for Portland Cement Concrete Materials 
Table 4-11. Summary of Reported Variabilities for Hardened

Cement Concrete Portland

Table A1. Probability of Obtaining a Random Value of Z Greater

Than the Values Shown in the Margins (after Steel and

Torrie $1980 \ldots \ldots \ldots \ldots \ldots \ldots \ldots \ldots \ldots \ldots \ldots \ldots \ldots \ldots \ldots \ldots$ A2

Table A2. Values of $t$ (after Fisher and Yates 1949) . . . . . . . A4

Table A3. Values of $\mathrm{X}^{2}$ (after Thompson 1941) . . . . . . . A6

Table A4. Values of $F$ (after Steel and Torrie 1980) . . . . . . . A8

Table A5. Critical Values for T When Standard Deviation is

Calculated from the Samples [after ASTM (1995b)

E 178] .

Table A6. Tietjen-Moore Critical Values (x1000) for $E_{k}$ [after ASTM (1995b) E 178] . . . . . . . . . . . . . . . . . A11

Table A7. Values of $\mathrm{F}_{\max }(\operatorname{after}$ Ott 1977) ... . . . . . A12

Table B1. Specific Gravity $\ldots \ldots \ldots \ldots \ldots \ldots \ldots$ B2

Table B2. Natural Water Content, Percent ............ B2

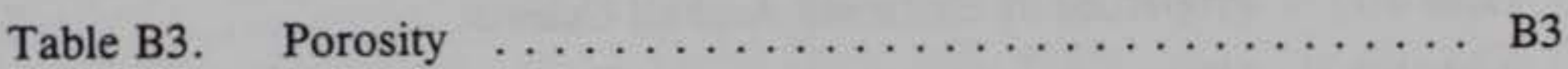

Table B4. Void Ratio .................... B3

Table B5. Degree of Saturation, Percent ... . . . . . . B B4

Table B6. Dry Density, $\mathrm{kg} / \mathrm{m}^{3} \ldots \ldots \ldots \ldots \ldots \ldots \ldots \ldots \ldots$

Table B7. Coefficient of Permeability, Percent ........... B4

Table B8. Liquid Limit, Percent . . . . . . . . . . . B5

Table B9. Plastic Limit Percent . . . . . . . . . . . . B6

Table B10. Plasticity Index, Percent . . . . . . . . . . . B6

Table B11. Particle Size Distribution, Percent Finer ... . . . . . B7

Table B12. Potential for Volume Change . . . . . . . . . . . B7

Table B13. Moisture-Density Relationship ............. B8

Table B14. Unconfined Compressive Strength $(\mathrm{kPa}) \ldots \ldots \ldots$ B8

Table B15. Measures of Shear Strength . . . . . . . . . . B9

Table C1. Controlled Moisture Content, Percent . . . . . . . . C2

Table C2. Field Compaction, Percent Relative to Laboratory

Density .................... C3

Table C3. Resilient Modulus, Mpa . . . . . . . . . . C4

Table C4. Measures of Stiffness and Strength . . . . . . . . C4

Table C5. Measures of Strength for Lime-Soil Mixtures and Soil-Cement .................. C5

Table D1. Controlled Moisture Content, Percent .......... D2 
Table D2. Atterberg Limits, Percent $\ldots \ldots \ldots \ldots \ldots \ldots \ldots$ D3

Table D3. Coefficient of Permeability, Percent $\ldots \ldots \ldots \ldots \ldots$ D3

Table D4. Particle Size Distribution, Percent Finer ......... D4

Table D5. Sand Equivalence, Percent $\ldots \ldots \ldots \ldots \ldots \ldots$ D7

Table D6. Magnesium Sulfate Soundness, Percent ......... D7

Table D7. Lift Thickness, $\mathrm{mm} \ldots \ldots \ldots \ldots \ldots \ldots \ldots \ldots$

Table D8. Field Compaction for Subbase Materials ${ }^{1}$, Percent

Relative to Laboratory Density . . . . . . . . . D9

Table D9. Field Compaction for Base Course Materials ${ }^{1}$, Percent Relative to Laboratory Density . . . . . . . . . D 10

Table D10. Measures of Stiffness and Strength . . . . . . . D11

Table D11. Measures of Stiffness and Strength for Lime- and CementStabilized Subbase and Base Course Materials ....... D12

Table D12. Measures of Stiffness and Strength for Asphalt-Stabilized Base Course Materials . . . . . . . . . . . . D13

Table E1. Properties of Extracted Asphalt Cement .......... E2

Table E2. Mixture Temperature in the Field $\ldots \ldots \ldots \ldots \ldots$ E2

Table E3. Extracted Asphalt Cement Content, Percent ......... E3

Table E4. Particle Size Distribution for Extracted Aggregates, Percent Finer . . . . . . . . . . . . E4

Table E5. Laboratory Density and Voids Analyses ........ E8

Table E6. Field Compaction, Percent Relative to Laboratory

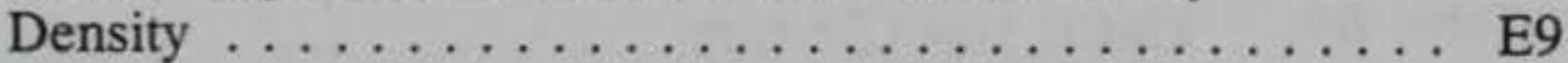

Table E7. Measure of Stiffness and Strength $\ldots \ldots \ldots \ldots \ldots$ E10

Table E8. Flexural Properties of Asphalt Concrete . . . . . . . E11

Table E9. Mat Thickness .................. E12

Table E10. Benkelman Bean Deflections, $\mathrm{mm} \ldots \ldots \ldots \ldots \ldots$ E12

Table E11. Falling Weight Deflectometer Results ......... E13

Table E12. Initial Serviceability Index $\ldots \ldots \ldots \ldots \ldots \ldots \ldots$ E14

Table F1. Air Content (Percent) of Concrete in its Plastic State ... F F2

Table F2. Slump (mm) of Concrete in its Plastic State . . . . . F2

Table F3. Particle Size Distribution for Concrete Aggregates,

Percent Finer . . . . . . . . . . . . . F3

Table F4. Fineness Modulus of Concrete Aggregates ........ F4

Table F5. Density of Hardened Concrete, $\mathrm{kg} / \mathrm{m}^{3} \ldots \ldots \ldots \ldots$ F4

Table F6. Compressive Strength of Hardened Concrete, MPA .... . F5 
Table F7. Compressive Modulus and Poisson's Ration for Hardened Concrete . . . . . . . . . . . . F6

Table F8. Measures of Tensile Stiffness and Strength ........ F6

Table F9. Slab Thickness, $\mathrm{mm} \ldots \ldots \ldots \ldots \ldots \ldots \ldots \ldots \ldots$ F7

Table F10. Load Transfer (Percent) $\ldots \ldots \ldots \ldots \ldots \ldots \ldots \ldots \ldots \ldots \ldots \ldots$ F8

Table F11. Falling Weight Deflectometer Results $\ldots \ldots \ldots \ldots \ldots$ F9

Table F12. Serviceability Index for Rigid Pavements ........ F9 


\section{Preface}

The investigation documented in this report was sponsored by the U.S. Army Corps of Engineers through the Research, Development, Testing, and Evaluation (RDT\&E) Program, Pavement Technology Work Package, Work Unit AT40-PT-014, "Characterization and Variability of Pavement Materials." The Corps of Engineers Technical Monitor was Mr. Ray Navidi, CEMP-ET.

This research was conducted by personnel of the Airfields and Pavements Division (APD), Geotechnical Laboratory (GL), at the U.S. Army Engineer Waterways Experiment Station (WES), Vicksburg, MS.

This study was conducted under the general supervision of Dr. William F. Marcuson III, Director, GL. Direct supervision was provided by Dr. Ray S. Rollings, Acting Chief, APD, and Mr. Timothy W. Vollor, Chief, Materials Analysis Branch (MAB), APD. The principal investigator for the project was Dr. Reed B. Freeman, MAB. The report was authored by Dr. Freeman and Mr. Bill Grogan, MAB.

Director of WES during the conduct of this study and preparation of the report was Dr. Robert W. Whalin. The Commander was COL Bruce K. Howard, EN.

The contents of this report are not to be used for advertising, publication, or promotional purposes. Citation of trade names does not constitute an official endorsement or approval of the use of such commercial products. 


\section{Introduction}

For the past several decades, the pavement construction industry has moved away from material and method specifications, toward quality assurance specifications. Material and method specifications required complete direction of construction by a representative of the contractual "owner." The contractor was directed to use specific materials and specific methods of placement. This type of specification created several problems. It prevented the contractor from using innovative materials or techniques and it obligated the owner to accept the final product regardless of quality.

Quality assurance specifications depend primarily on end-result criteria, which require the contractor to take responsibility for supplying a product or an item of construction. The owner's responsibility is then either to accept or reject the final product or to apply a price adjustment that compensates for the degree of compliance with the specifications (TRB 1996).

The end-result criteria used for a quality assurance specification must be related to pavement performance. These criteria involve testing for material and structural characteristics that are known to correlate with pavement performance (e.g. void content and thickness for asphalt concrete). The characteristics used for end-result criteria are often not fundamental engineering properties (e.g. resilient modulus or fatigue resistance) because they have to be highly repeatable and amenable to timely acceptance testing (TRB 1996).

To execute a quality assurance specification properly, the contractor must implement a quality control (QC) program and the owner must implement a quality assurance (QA) program. A QC program involves sampling and testing during construction to control the level of quality of the final product. A QA program involves all the actions necessary to provide confidence that a product or facility will perform satisfactorily in service. The QA program must include acceptance sampling and testing to determine if the quality of produced material or construction is acceptable in terms of the specifications (TRB 1996).

The results of QA acceptance tests are compared to acceptance limits, which usually include provisions for pay adjustments. These acceptance limits must be realistic, particulary when nonconformance results in reduced pay for a contractor. The principal obstacle for developing realistic limits is 
the ability to predict with some degree of accuracy the amount of variability that should be expected in "satisfactory" construction (Nicotera 1974).

\section{Problem}

The pavement industry has not maintained or published extensive variability data related to materials and construction, as have other fields of engineering and science. Pavement construction has long been regarded as an art that is highly dependent on the skills and experience of the field engineer, so decisions have often been based on engineering judgement. The use of traditional material and method specifications for pavement projects has been accompanied by a minimal amount of conformance testing. Consequently, there has typically not been an organized method for resolving disputes when materials or methods used for pavement construction are suspected to not conform with specification requirements. Other industries, in contrast, involve production lines in a controlled environment that includes conformance testing. Successful automobile manufacturing, for example, has relied on a statistical approach to quality control for over 40 years.

The pavement industry is now adopting statistics-based specifications and reliability assessments for several reasons. First, the pace of pavement construction projects has increased, necessitating that the parties involved share responsibilities. Secondly, the duties of engineers has become more widespread, requiring that they spend time away from their field projects. Finally, modern construction has been besieged with litigation. Owners must therefore protect themselves by writing clear specification requirements that are based on fair assumed risks by all contractual parties.

\section{Scope}

This report has two purposes. First of all, it describes probabilistic and statistical tools that are useful for analyzing the variability of pavement materials and pavement structures. Secondly, this report presents a summary of published variability data pertaining to pavements. These tools and data will be useful for the development of fair and enforceable quality assurance specifications.

Basic statistical concepts are reviewed in Chapter 2 to prepare the reader for the variability analysis tools presented in Chapter 3. Published variability data are summarized in Chapter 4 and are presented in detail, with references, in the appendices. 


\section{Statistical Concepts}

This chapter provides a review of basic probabilistic and statistical concepts, which will be used for analyses of material variability later in this report. This chapter should be useful to those who develop, write, and implement statistics-based construction specifications.

\section{Terminology}

\section{Population versus sample}

A population is a set of data that includes an entire entity of interest. If an Army installation is conducting inventory on its highway system, the design thicknesses of all portland cement concrete (PCC) pavements would be considered a population of data. A sample is a set of data that is selected randomly from within a population, typically to represent the population from which it was derived. If an Army installation were to make a judgement concerning the thicknesses of its PCC pavements by coring 100 randomly-selected slabs, the selected slabs would constitute a sample of the installation's population of PCC pavements.

\section{Unit, observation, and variable}

A set of data is composed of information gathered from a number of experimental units. The information gathered from each experimental unit is called an observation. Each observation may consist of one or more pieces of information, called variables.

Example. If an Army installation wishes to gather information about nearby sources of asphalt cement, each source of asphalt cement would be a unit. The observation for each of these units may consist of several variables, such as specific gravity, solubility, and viscosity at a given temperature. 


\section{Types of variables}

Variables may be continuous or discrete. Continuous variables can take on any value within a given interval.

Example. The asphalt cement content of hot-mix asphalt (HMA), which could be measured from extractions performed on pavement core samples, is a continuous variable. Conceptually, the asphalt cement content could be any value between and including 0 percent and 100 percent. Similar to almost all continuous variables, the reported measurements of asphalt cement content are limited to discrete increments due to the limited precisions of measurement devices. Reported asphalt cement contents are typically limited to increments of one-tenth of a percent.

A discrete variable must assume a single category from within a predetermined list. These categories may be based on a nominal scale or an ordinal scale. In a nominal scale, each category is given a name. The category names may be alphabetic, numeric, or alphanumeric.

Example. If an Army installation is conducting inventory on its roadway system, they may classify each pavement section by an alphabetic name that reflects the nature of its design: rigid, flexible, or unsurfaced. As an example of numeric categories in a nominal scale, an installation may classify its roadways according to their number of lanes. All observations for the number of lanes would be discrete; commonly, 2 or 4 . In this case, the discrete variable names would have quantitative implications.

An ordinal scale for a discrete variable involves a ranking procedure. These ranks are typically given integer values including " 1 " for either the lowest rank or the highest rank.

Example. If an Army installation is concerned with surface scaling deterioration for reinforced concrete bridge decks, they may inspect their bridge decks visually and then rank the appearances of the bridge decks with an ordinal scale.

\section{Frequency Distributions}

A frequency distribution is a fundamental method for summarizing data. In order to construct this distribution, descriptive categories (or class intervals) are established so that each data observation falls into a single category. The number of observations that fall within each category are then counted and tabulated. The necessary descriptive categories may exist naturally for discrete variables, but they must be fabricated for continuous variables. The appropriate number of class intervals is usually between 5 and 20 , depending on the number of observations and the apparent trends in the data (Spiegel 1988). The frequency of occurrences for the various class intervals form the basis of a frequency distribution. 
Example. Frequency of occurrences for a continuous variable, California bearing ratio of a silty gravel, are developed in Table 2-1.

\begin{tabular}{|l|l|l|l|l||}
\hline \multicolumn{5}{||l}{$\begin{array}{l}\text { Table 2-1 } \\
\text { California Bearing Ratio for a Silty Gravel }\end{array}$} \\
\hline \hline & $\begin{array}{l}\text { Class } \\
\text { Mark' }\end{array}$ & Frequency & $\begin{array}{l}\text { Relative } \\
\text { Frequency }\end{array}$ & $\begin{array}{l}\text { Cumulative } \\
\text { Relative } \\
\text { Frequency }\end{array}$ \\
\hline \hline 25 to 29 & 27 & 2 & 0.018 & 0.018 \\
\hline 30 to 34 & 32 & 4 & 0.036 & 0.055 \\
\hline 35 to 39 & 37 & 7 & 0.064 & 0.118 \\
\hline 40 to 44 & 42 & 11 & 0.100 & 0.218 \\
\hline 45 to 49 & 47 & 15 & 0.136 & 0.354 \\
\hline 50 to 54 & 52 & 18 & 0.164 & 0.518 \\
\hline 55 to 59 & 57 & 20 & 0.182 & 0.700 \\
\hline 60 to 64 & 62 & 14 & 0.127 & 0.827 \\
\hline 65 to 69 & 67 & 12 & 0.109 & 0.936 \\
\hline 70 to 74 & 72 & 5 & 0.046 & 0.982 \\
\hline 75 to 79 & 77 & 2 & 0.018 & 1.000 \\
\hline Total & & 110 & 1.000 & \\
\hline \hline 1 Midpoint of class interval. & & & \\
\hline
\end{tabular}

Once the frequencies of occurrence are established, they can be converted to relative frequencies by expressing the number of observations for each category as a proportion of the total number of observations (Table 2-1). Each relative frequency, which takes a value between 0.0 and 1.0 , represents an estimated probability that an observation will take on a value within its descriptive data category. For this reason, relative frequencies are often referred to as empirical probabilities (Freund and Wilson 1993). Once relative frequencies are established, they can be converted to cumulative relative frequencies, which also take values between 0.0 and 1.0 (Table 2-1). Cumulative relative frequencies are often referred to as empirical cumulative probabilities.

A histogram is a graphical representation of either frequencies of occurrence or relative frequencies (Figure 2-1). These histograms are often referred to as frequency distributions or relative frequency distributions, depending on the type of ordinate used. These histograms provide an easyto-interpret view of both the range of measurements and the shape of the distribution of measurements. Important characteristics of the shape include symmetry and data dispersion. Overlaying the histogram with a cumulative 


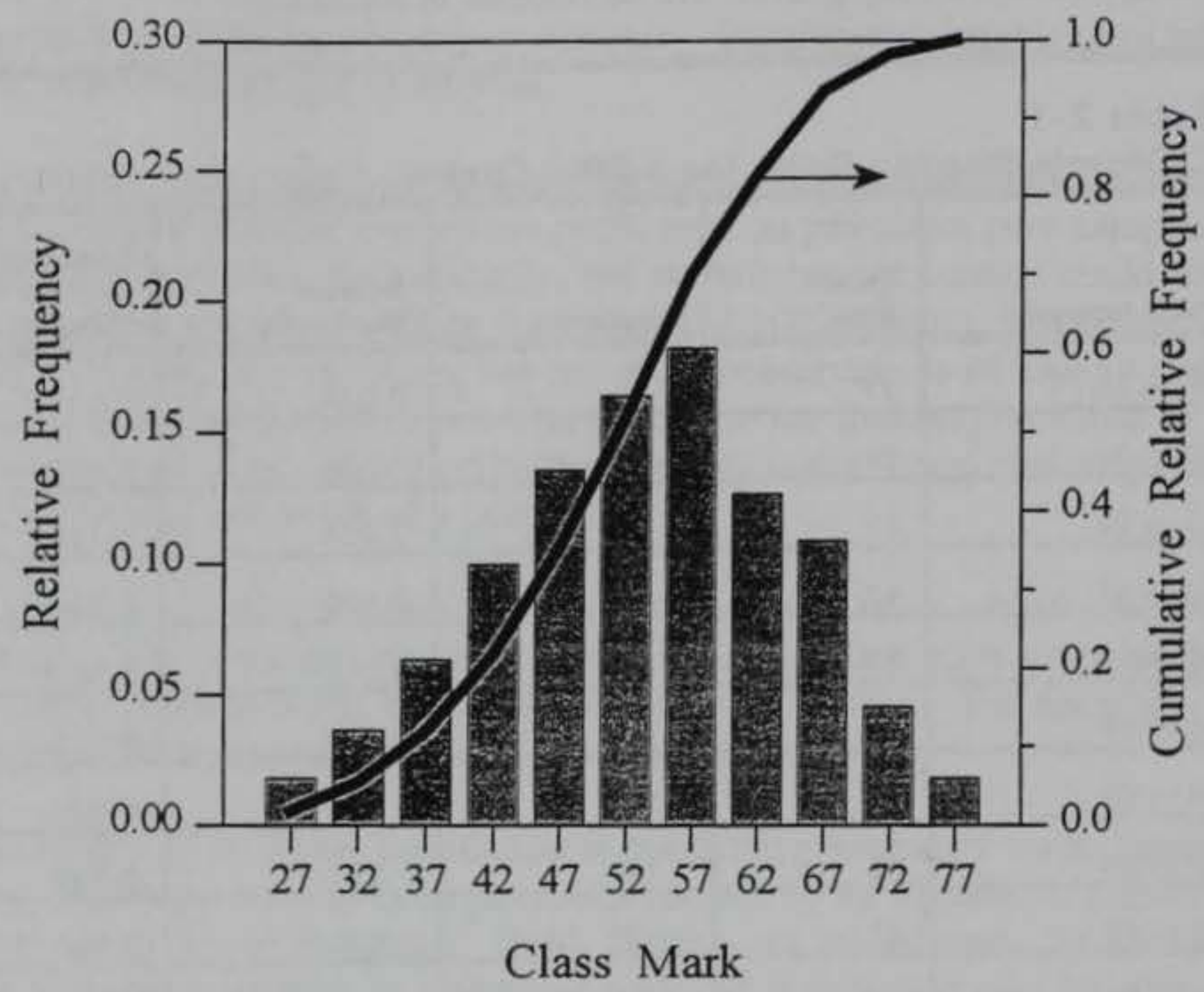

Figure 2-1. Relative frequency distribution for soil CBR

relative frequency plot provides the viewer with an additional perspective of the same data, as shown in Figure 2-1.

\section{Numerical Descriptive Statistics}

Although frequency distributions provide useful descriptions of data, numerical descriptors are often needed for quantitative comparisons between data sets. When numerical descriptors are used to represent frequency distributions, however, some information may be lost (e.g. the shape of the frequency distribution). For this reason, numerical descriptors must be used with care and with knowledge of any accompanying assumptions.

\section{Central tendency}

One of the most useful single characteristics of a distribution is its central tendency. Central tendency can be calculated several ways, including those listed below (Freund and Wilson 1993). These methods of calculating central tendency are valid for both populations of data and samples of data. Mean is the most commonly used measure of central tendency. 
a. Mean. The mean is the sum of all values (assuming a finite population size) divided by the number of values. A mean for a population is commonly denoted $\mu$ and a mean for a sample is commonly denoted $y$ (where the individual sample observations are denoted $y_{\mathrm{i}}$ ). As an example, the mean of the relative density data in Table $2-2$ is 97.33 $(=1557.2 / 16)$.

\begin{tabular}{|c|c|c|c|c|}
\hline \multicolumn{5}{|c|}{$\begin{array}{l}\text { Table 2-2 } \\
\text { Relative Densities for Hot Mix Asphalt }\end{array}$} \\
\hline $\begin{array}{l}\text { Ordered } \\
\text { Observation }\end{array}$ & $\begin{array}{l}\text { Ordered } \\
\text { Measurement (Percent) }\end{array}$ & $y_{1}=\bar{y}^{2}$ & $\left(y_{1}-\bar{y}\right)^{2}$ & $\left(y_{1}-\bar{y}\right)^{3}$ \\
\hline 6 & 96.8 & -0.53 & 0.276 & -0.145 \\
\hline 7 & 96.9 & -0.42 & 0.181 & -0.077 \\
\hline 15 & 97.0 & -0.33 & 0.106 & -0.034 \\
\hline 5 & 97.1 & -0.23 & 0.051 & -0.011 \\
\hline 13 & 97.2 & -0.13 & 0.016 & -0.002 \\
\hline 1 & 97.3 & -0.03 & 0.001 & 0.000 \\
\hline 4 & 97.3 & -0.03 & 0.001 & 0.000 \\
\hline 9 & 97.4 & 0.08 & 0.006 & 0.000 \\
\hline 14 & 97.4 & 0.08 & 0.006 & 0.000 \\
\hline 2 & 97.5 & 0.17 & 0.031 & 0.005 \\
\hline 10 & 97.5 & 0.17 & 0.031 & 0.005 \\
\hline 11 & 97.5 & 0.17 & 0.031 & 0.005 \\
\hline 16 & 97.5 & 0.17 & 0.031 & 0.005 \\
\hline 3 & 97.6 & 0.27 & 0.076 & 0.021 \\
\hline 8 & 97.6 & 0.27 & 0.076 & 0.021 \\
\hline 12 & 97.6 & 0.27 & 0.076 & 0.021 \\
\hline sum & 1557.2 & 0.00 & 0.99 & -0.18 \\
\hline
\end{tabular}

b. Median. The median is the middle value when the measurements are arranged from lowest to highest. The median will be the average of two values if the number of measurements is even. The median of the relative density data in Table $2-2$ is 97.4 .

c. Mode. The mode is the most frequently occurring measurement. The mode will not be a unique value if two or more measurements occur with the same greatest frequency. The mode will not be defined if each measurement occurs only once. The mode of the relative density data in Table $2-2$ is 97.5 . 
d. Geometric Mean. The geometric mean is the $\mathrm{N}^{\text {th }}$ root of the product of $\mathrm{N}$ values. The geometric mean will not be defined if any measurements are less than or equal to zero. The geometric mean of the relative density data in Table $2-2$ is 97.31 .

e. Midrange. The midrange is the average of the smallest and largest measured values. The midrange is not often used because it ignores most of the information provided by the data. The midrange of the relative density data in Table $\mathbf{2 - 2}$ is 97.20 .

\section{Dispersion}

The variability or dispersion of a data set is also important and should be quantified if possible. A value for dispersion will provide an indication of whether a frequency distribution is "broad" or "narrow," however, it will not provide an indication of symmetry (or skewness). The simplest measure of dispersion is the range, which is defined as the difference between the largest and smallest observed values. Similar to the calculation for midrange, the calculation for range ignores most of the values in a data set and therefore has limited usefulness.

Another measure of dispersion, called variance, is commonly used. Variance is represented by two symbols, depending on its application (Steel and Torrie 1980): $\sigma^{2}$ is used if the data set is a population and $s^{2}$ is used if the data set is a sample. The population variance (assuming discrete observations) is defined as the sum of squared deviations from the mean, divided by the total number of observations, $N$ :

$$
\sigma^{2}=\frac{\sum_{i=1}^{N}\left(y_{i}-\mu\right)^{2}}{N}
$$

where

$$
\begin{aligned}
& y_{i}=\text { value for each observation } \\
& \mu=\text { population mean } \\
& N=\text { number of units in the population }
\end{aligned}
$$

The numerator in Equation 1 is often referred to as the "sum of squared deviations" or the "sum of squares." In order to simplify computations, the sum of squares equation can be transformed to a working formula:

$$
\sum_{i=1}^{N}\left(y_{i}-\mu\right)^{2}=\sum_{i=1}^{N} y_{i}^{2}-\frac{\left(\sum_{i=1}^{N} y_{i}\right)^{2}}{N}
$$


The calculation of sample variance, $s^{2}$, is similar to the calculation of population variance with the exception that the divisor is $(n-I)$, rather than $N$ :

$$
s^{2}=\frac{\sum_{i=1}^{n}\left(y_{i}-\bar{y}\right)^{2}}{n-1}
$$

where

$y_{i}=$ value for each observation

$\bar{y}=$ sample mean

$n=$ number of units in the sample

The necessity of using ( $n-1)$ as the divisor for the sample variance (Equation 3), rather than $n$, is a consequence of using a sample statistic, $\bar{y}$, as an estimate of a population parameter, $\mu$, in its calculation. While population parameters are fixed values, sample statistics are random variables. This idea will be expanded upon in the section titled, "Sampling Distributions."

For the relative density data in Table $2-2$, variance is calculated as:

$$
s^{2}=\frac{0.99}{15}=0.066 \text { percent }^{2}
$$

In addition to range and variance, the dispersion of a data set may be quantified by its standard deviation. Standard deviation is simply the square root of the variance, as shown below. At times, the standard deviation is convenient because its units are the same as the units for the data from which it is calculated.

$$
\begin{aligned}
& \sigma=\sqrt{\sigma^{2}} \quad \text { and } \\
& s=\sqrt{s^{2}}
\end{aligned}
$$

where

$$
\begin{aligned}
& \sigma=\text { standard deviation for a population } \\
& s=\text { standard deviation for a sample }
\end{aligned}
$$

For the relative density data in Table $2-2$, standard deviation is calculated as: 


$$
s=\sqrt{s^{2}}=\sqrt{0.066}=0.257 \text { percent }
$$

Since sample standard deviations and variances are themselves variables, several independent estimates for these statistics may be available. The proper method for combining these estimates is to calculate a weighted average for variance, with the weights proportional to the respective degrees of freedom [Granley 1969, ASTM (1995b) E 178]. The calculation of weighted average for variance is often called "pooling" the variance estimates:

$$
\text { pooled sample variance }=\frac{\sum_{i=1}^{M}\left[\left(s_{i}^{2}\right)\left(n_{i}-1\right)\right]}{\sum_{i=1}^{M} n_{i}-M}
$$

where

$$
\begin{aligned}
& n_{\mathrm{i}}=\text { number of tests in project i } \\
& M=\text { number of projects }
\end{aligned}
$$

Pooling is essentially a weighted average with the degrees of freedom in each project $\left(n_{i}-1\right)$ as the weighting factor. If the number of tests within each project are the same, the pooled value is equal to the straight average.

Finally, the dispersion of a data set can be quantified by a coefficient of variation $(\mathrm{CV})$, as shown below. The coefficient of variation can be described as the standard deviation expressed as a percentage of the mean. This measure of dispersion has advantages at times because the magnitude of the mean and the units of measure are factored out. Using CV, distributions representing data with different units and distributions representing data with different means can all be compared in terms of their dispersion. Equations for computing $\mathrm{CV}$ for both populations and samples are shown below.

$$
\begin{aligned}
& C V=\frac{\sigma}{\mu} \times 100 \% \quad \text { or } \\
& C V=\frac{s}{\bar{y}} \times 100 \%
\end{aligned}
$$

For the relative density data in Table $2-2$, coefficient of variation is calculated as:

$$
C V=\frac{0.257}{97.33} \times 100 \%=0.26 \%
$$




\section{Shape}

Skewness is a measure of the degree of symmetry for a frequency distribution. If the right tail of a frequency distribution extends farther from the central maximum than the left tail, the distribution is said to be skewed positively (Figure 2-2). If the left tail of a frequency distribution extends farther from the central maximum than the right tail, the distribution is said to be skewed negatively (Spiegel 1990). The moment coefficient of skewness for a population $\left(\beta_{1}\right)$ is calculated as:

$$
\beta_{1}=\frac{\sum_{i=1}^{N}\left(y_{i}-\mu\right)^{3}}{N \cdot s^{3}}
$$

The moment coefficient of skewness for a sample $\left(b_{l}\right)$ is calculated as (SAS 1988):

$$
b_{1}=\frac{n}{(n-1)(n-2)} \times \frac{\sum_{i=1}^{n}\left(y_{i}-\bar{y}\right)^{3}}{s^{3}}
$$

If a distribution is positively skewed, its moment coefficient of skewness will be positive. If a distribution is negatively skewed, its moment coefficient of skewness will be negative. If a distribution is symmetric, its moment coefficient of skewness will be equal to zero. By raising the standard deviation in the denominator to a power of three, the moment coefficient of skewness becomes unitless.

For the relative density data in Table $2-2$, coefficient of skew is calculated as:

$$
b_{1}=\frac{16}{15 \cdot 14} \times \frac{-0.18}{(0.257)^{3}}=-0.83
$$

\section{Discrete Probability Distributions}

Relative frequency distributions were described previously as empirical probability distributions. Relative frequency distributions are considered empirical because they are usually constructed from sample values. Relative frequency distributions can also be called "discrete" distributions because they are constructed from data that has been categorized into discrete class intervals. 


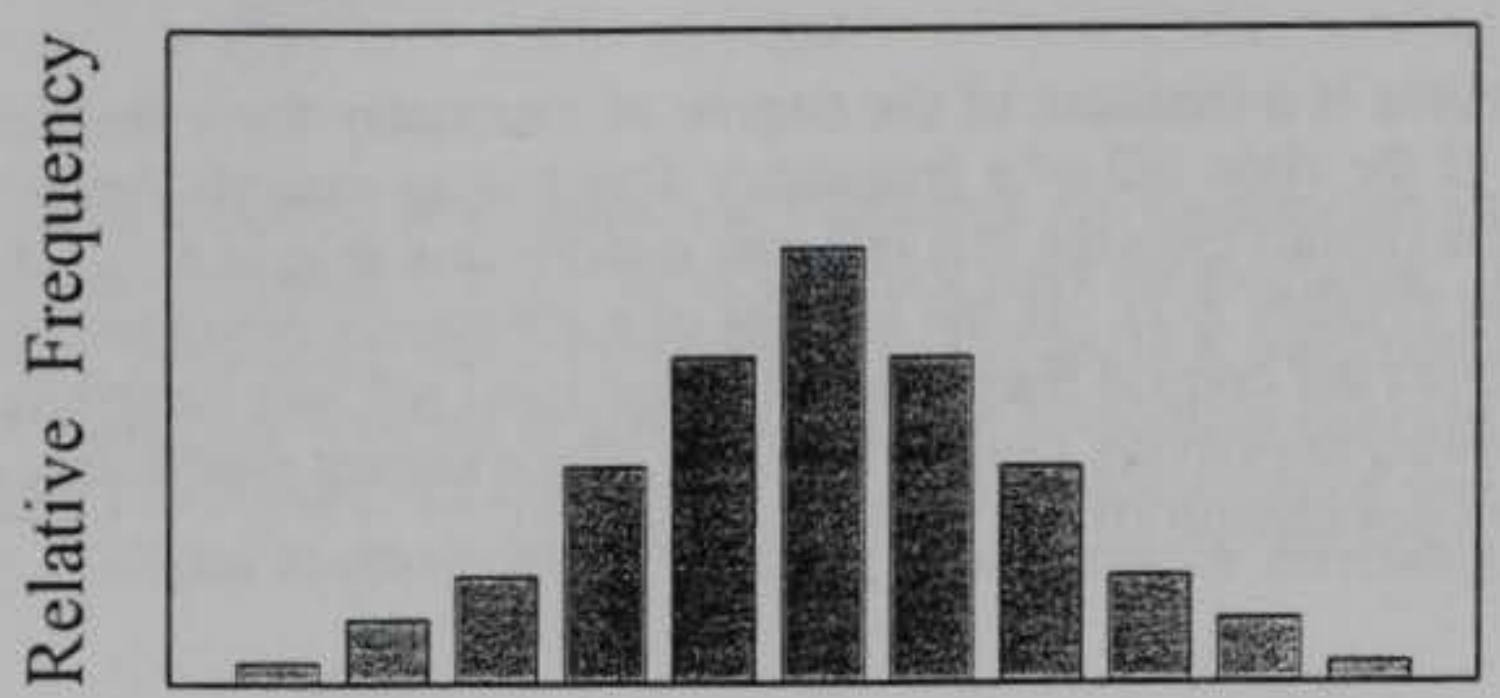

Class Mark

a.

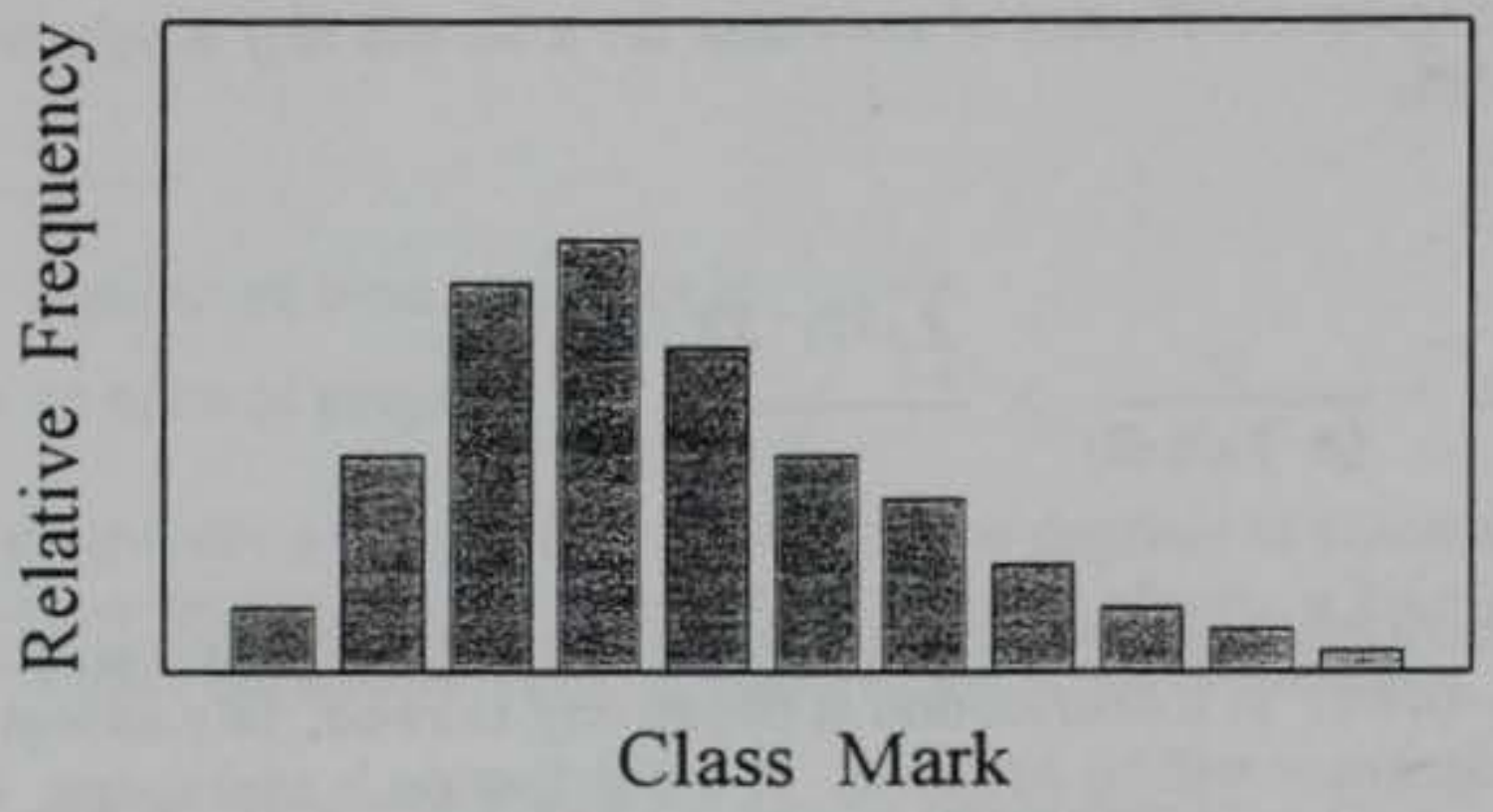

b.

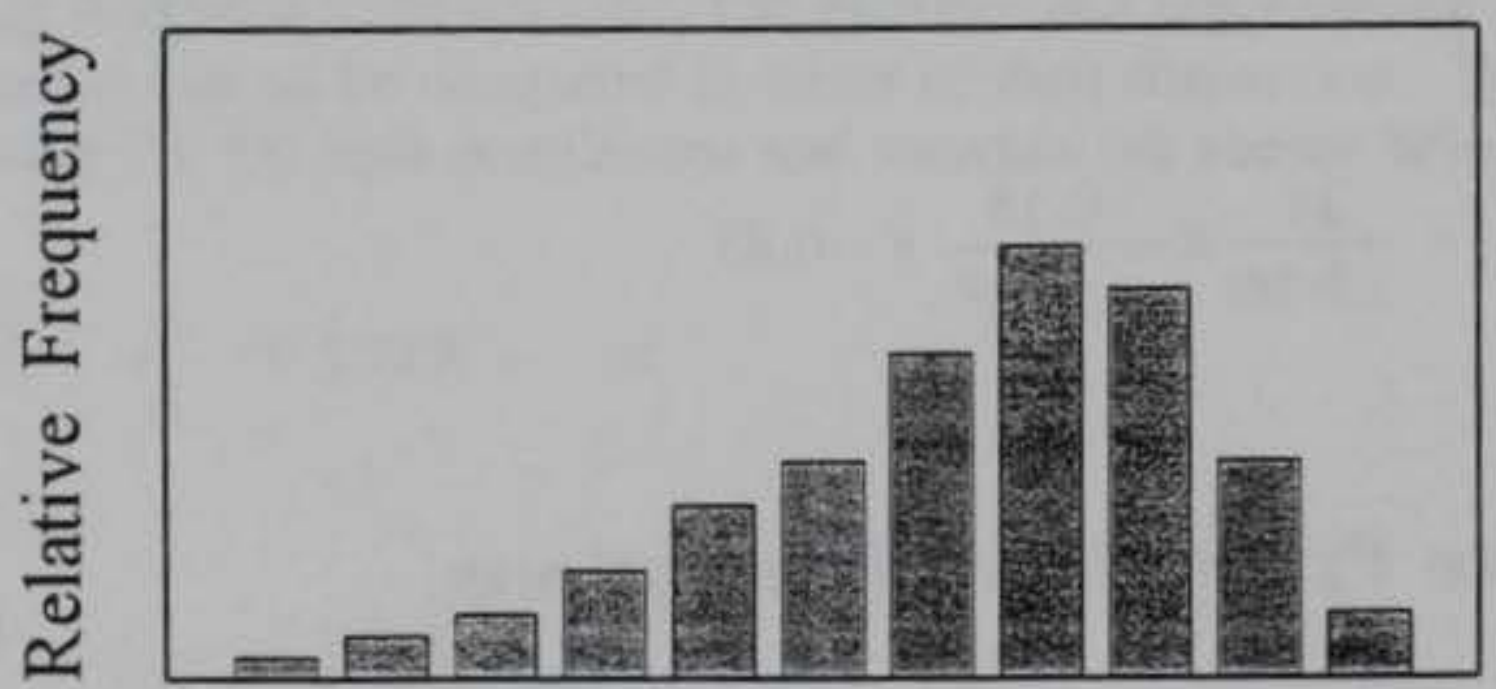

Class Mark

c.

Figure 2-2. Relative frequency distributions with various skew: (a) symmetric, (b) positive skew, and (c) negative skew 
Contrary to relative frequency distributions, which are constructed from sample data, the construction of probability distributions is based on assumptions related to either the shape of the distribution or the probability of occurrence for each discrete value. Probability distributions are therefore theoretical, rather than empirical, and represent theoretical characteristics of a population of data.

\section{Binomial distribution}

A relatively simple and useful discrete probability distribution is the binomial distribution. This distribution is applicable for statistical problems that include "repeated trials." In these situations, we are interested in the probability of getting $x$ successes in $n$ trials. In order for the binomial distribution to apply, the following assumptions must also be true (Johnson 1994).

a. There are only two possible outcomes for each trial (usually referred to as "success" and "failure").

$b$. The probability of success $(p)$ is the same for each trial.

c. The $n$ trials are independent.

Let $Y$ be the random variable that represents a set of all possible successes in $n$ trials. The probability of the occurrence of $y$ successes, which is represented as $p(y)$, can be calculated for each possible value of $y$. The binomial distribution can then be constructed by plotting $p(y)$ as a function of the discrete values of $y$. In order to emphasize the fact that $p(y)$ is calculated for a binomial distribution, $p(y)$ is often denoted by $b(y ; n, p)$.

$$
b(y ; n, p)=\left(\begin{array}{l}
n \\
y
\end{array}\right) p^{y}(1-p)^{n-y} \text { for } y=0,1,2, \ldots, n
$$

where

$$
\left(\begin{array}{l}
n \\
y
\end{array}\right)=\frac{n !}{y !(n-y) !}
$$

Cumulative probabilities of the binomial distribution are often needed for statistical applications. The cumulative binomial probability, $B$, can be calculated as follows:

$$
B(k ; n, p)=\sum_{y=0}^{k} b(y ; n, p) \text { for } k=0,1,2, \ldots, n
$$


The mean and the variance for the binomial random variable $y$ can be calculated without constructing the probability distribution, provided that the two distribution parameters $n$ and $p$ are known.

$$
\begin{aligned}
& \mu=n p \quad \text { and } \\
& \sigma^{2}=n p(1-p)
\end{aligned}
$$

If $n$ is large, calculating the binomial probabilities and the cumulative binomial probabilities can be cumbersome. Statistical software packages are often equipped to handle these calculations. In addition, many textbooks include an appendix with cumulative binomial probabilities tabulated for a range of values for each of $y, n$, and $p$.

Example. Assume that a contractor is removing concrete cores from a rigid pavement. The contractor needs four cores that remain intact and are of sufficient length for compression testing (successes). He/she knows from experience that only about one-half of the cores attempted are of sufficient quality (successes), so $p=0.5$. If the contractor's crew is cutting 12 cores $(n=12)$, his/her binomial distribution for this situation is shown in Figure 2-3. The probability that the contractor will obtain three or fewer quality cores is only 7 percent. The probability that the contractor will obtain the necessary four quality cores, or even more, is approximately 93 percent.

\section{Continuous Probability Distributions}

Probability distributions can also be constructed for continuous random variables, which can assume an infinite number of different values (any value within an interval). Continuous probability distributions for these continuous variables have the following characteristics (Freund and Wilson 1993).

a. The graph of the distribution is usually a smooth curve. This is in contrast to the histogram type of distribution for discrete variables.

$b$. The curve is described by an equation, $f(y)$, called the distribution function. This function corresponds to $p(y)$ for discrete variable distributions.

c. The total area under the curve is one. This corresponds to the sum of all possible probabilities for discrete variables.

d. The probability of a random variable taking a value within an interval $(a, b)$ is equal to the area between the distribution curve and the horizontal axis within the interval $(\mathrm{a}, \mathrm{b})$. This corresponds to adding probabilities for discrete variables. 


\section{Normal distribution}

The normal distribution is a continuous distribution that has proved to be useful in many applications. The normal distribution was developed in the eighteenth century when scientists observed regularity in errors of measurement, caused by laws of chance. They called the family of distributions the "normal curve of errors" and fit the following continuous equation, often referred to as the normal probability density function (Johnson 1994).

$$
f(y)=\frac{1}{\sigma \sqrt{2 \pi}} \exp \left[\frac{-(y-\mu)^{2}}{2 \sigma^{2}}\right]
$$

where

$$
-\infty<y<\infty
$$

The position and breadth of the resulting normal probability density function is dependent on only two parameters: mean $(\mu)$ and standard deviation $(\sigma)$. The curve is always bell-shaped and symmetric about the mean, so its degree of skewness is always zero. The breadth of the curve increases with increasing $\sigma$. This effect is shown in Figure 2-4 for functions with a mean of 0 and standard deviations of $1 / 2,1$, and 2 . While the breadth of normal distributions can change, the following rules of thumb remain applicable for data dispersion (Willenbrock 1974b).

a. Approximately 68.0 percent of the data falls within plus or minus one standard deviation from the mean $(\mu \pm \sigma)$.

b. Approximately 95.5 percent of the data falls within plus or minus two standard deviations from the mean $(\mu \pm 2 \sigma)$.

c. More than 99.7 percent of the data falls within plus or minus three standard deviations from the mean $(\mu \pm 3 \sigma)$.

\section{Standard normal distribution}

The calculus required to integrate under normal distribution curves can be quite complex, so probabilities related to areas under these density functions are seldom calculated without the aid of computer software. If software is not convenient for a particular application, tables representing a standard normal distribution can be used to facilitate manual calculations. The standard normal distribution has a mean of zero and a standard deviation of one, resulting in the probability density function shown below.

$$
f(y)=\frac{1}{\sqrt{2 \pi}} \exp \left[\frac{-y^{2}}{2}\right]
$$




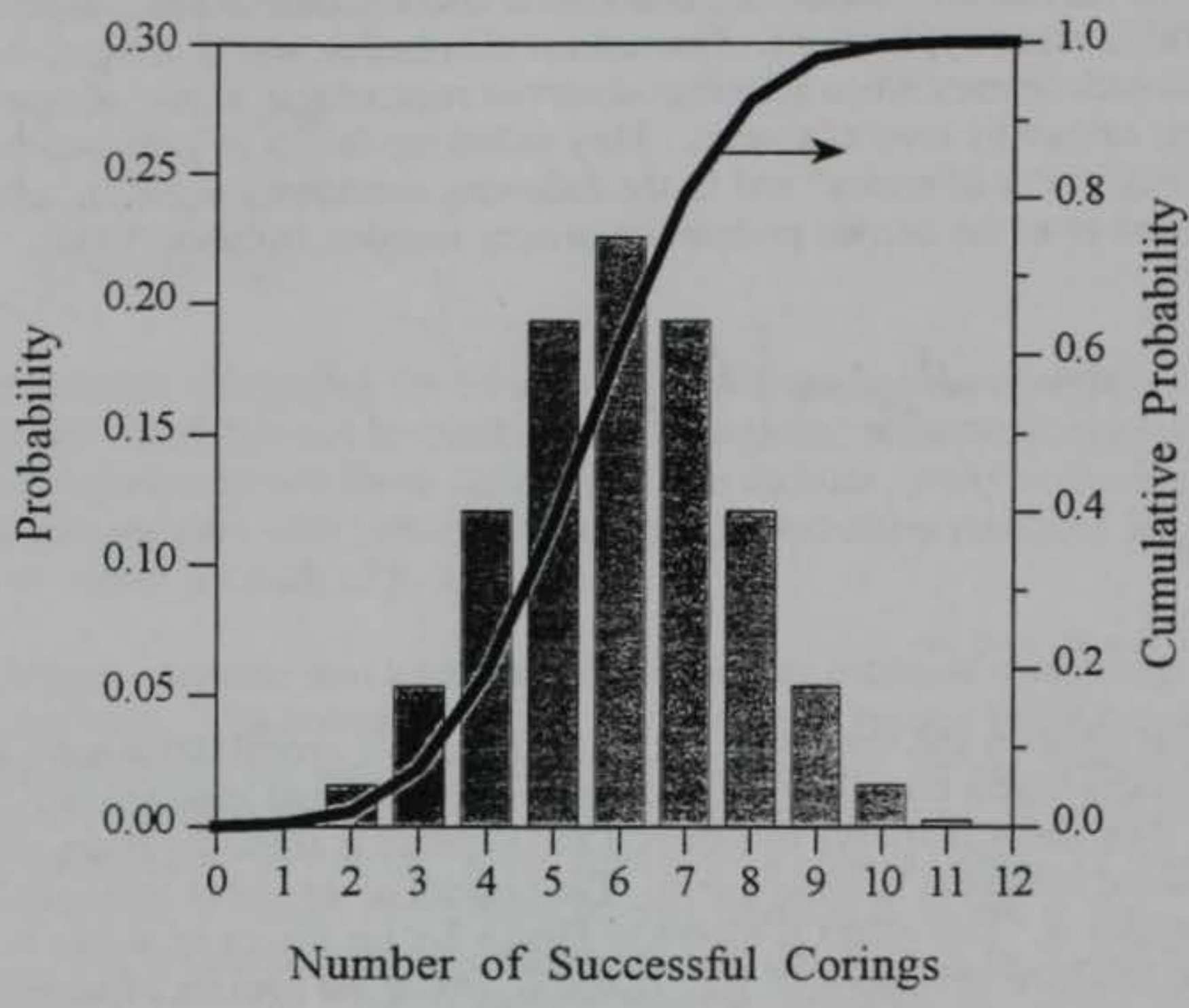

Figure 2-3. Discrete binomial distribution

where

$$
-\infty<y<\infty
$$

For all normal distributions, the degree of skewness is zero.

The random variable associated with the standard normal distribution is usually represented by the letter $Z[=\{z\}]$. Areas under a normal distribution for any variable $Y[=\{y\}]$ can be determined by converting a specific value $y$ to a value $z$ according to the equation below. The calculated value $z$ can then be used as input for standard normal distribution tables, such as that shown in Table A1 (Appendix A), to determine the probability of finding measurements less than or greater than $y$.

$$
z=\frac{y-\mu}{\sigma}
$$

Example. Assume that a specific mixture of portland cement concrete is required to have a compressive strength greater than or equal to $34 \mathrm{MPa}$ and 
that the concrete supplier involved has historically reported coefficients of variation for strength in the range of 20 percent. If the average compressive strength for the delivered concrete is $40 \mathrm{MPa}$, we can use the " $\mathrm{Z}$ " tables to calculate the probability that a measured compressive strength will fall below the specified $34 \mathrm{MPa}$. From the given values for coefficient of variation and mean, the standard deviation of compressive strengths is calculated to be $8 \mathrm{MPa}(0.2 \times 40 \mathrm{MPa})$. The $\mathrm{z}$-value that corresponds to a $\mathrm{y}$-value of $34 \mathrm{MPa}$ equals -0.75 . Since the standard normal distribution is symmetric, we know that the probability of obtaining a value of $z$ less than -0.75 is equal to the probability of obtaining a value of $z$ greater than +0.75 . Therefore, using the standard $\mathrm{Z}$ table (Table A1) and interpolation, we can determine that the probability of measuring a compressive strength smaller than the specified $34 \mathrm{MPa}$ equals 0.2266 or 23 percent. The assumed normal distribution for compressive strength, along with a cumulative probability distribution, are plotted in Figure 2-5. As expected, the cumulative probability at $34 \mathrm{MPa}$ is approximately 0.23 .

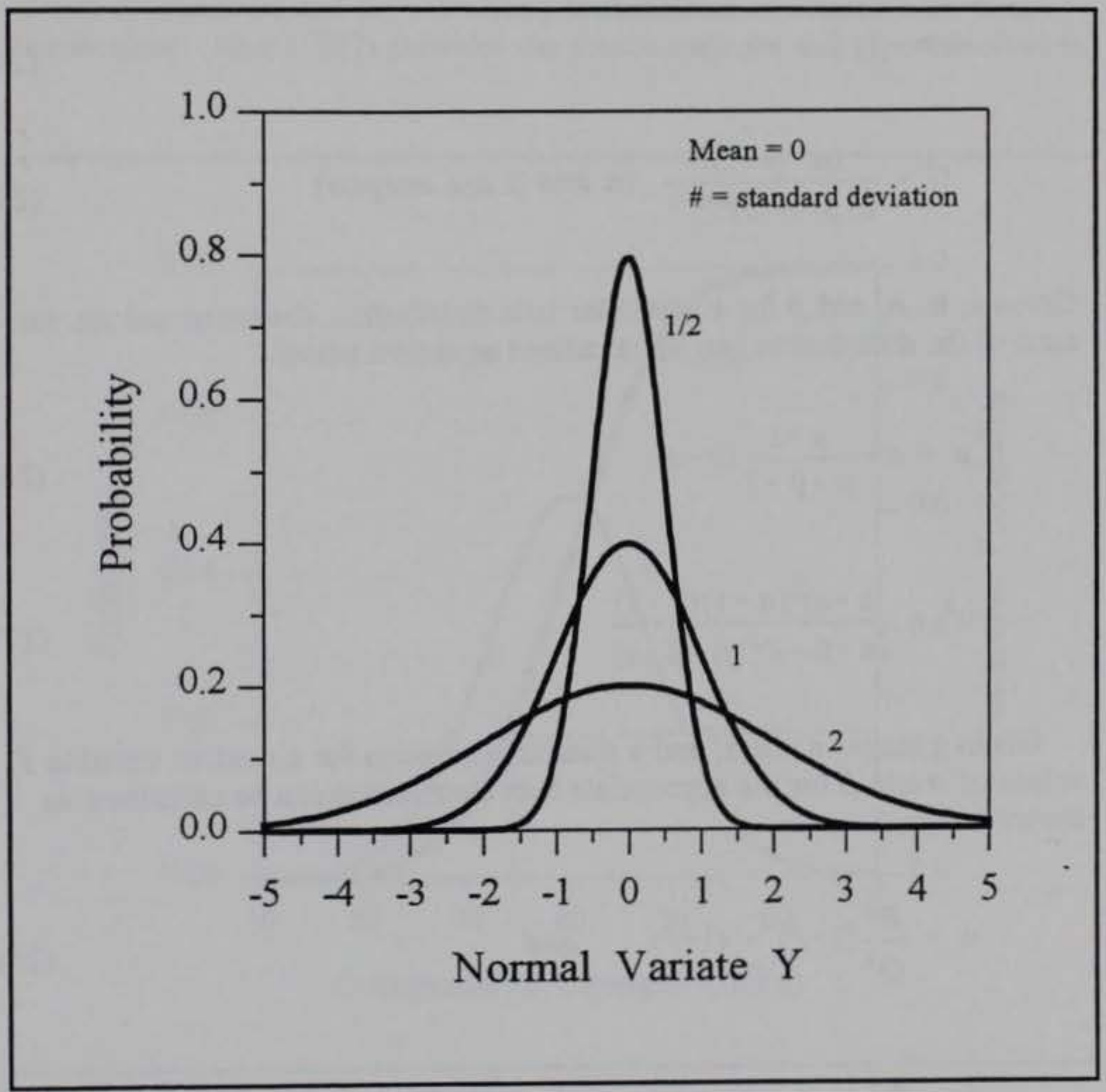

Figure 2-4. Effect of standard deviation on the breadth of a normal distribution 


\section{Beta distribution}

The normal distribution is not the most appropriate representation for all applications. Some random variables are represented more accurately by distributions with finite limits. For example, California bearing ratio (CBR) measurements for a high-plasticity clay would have a mean close to zero and a relatively high standard deviation. However, the real-life measurements could never have a value less than zero. In cases such as this and for skewed distributions, a beta distribution may be more applicable than a normal distribution. Beta probability distributions are continuous and they have a finite range from $y=a$ to $y=b$. These probability distributions can be described by the density function shown below (Harr 1987).

$$
f(y)=C(y-a)^{\alpha}(b-y)^{\beta}
$$

where

$$
\begin{aligned}
& \alpha>-1, \beta>-1, \text { and } \\
& C=\frac{(\alpha+\beta+1) !}{\alpha ! \beta !(b-a)^{\alpha+\beta+1}} \quad(\alpha \text { and } \beta \text { are integers })
\end{aligned}
$$

Given a, b, $\alpha$, and $\beta$ for a particular beta distribution, the mean and the variance of the distribution can be calculated as shown below.

$$
\begin{aligned}
& \mu=a+\frac{\alpha+1}{\alpha+\beta+2}(b-a) \\
& \sigma^{2}=\frac{(b-a)^{2}(\alpha+1)(\beta+1)}{(\alpha+\beta+2)^{2}(\alpha+\beta+3)}
\end{aligned}
$$

Given a range, a mean, and a standard deviation for a random variable $Y$, values of $\alpha$ and $\beta$ for the appropriate beta distribution can be calculated as shown below.

$$
\begin{aligned}
& \alpha=\frac{P^{2}}{Q^{2}}(1-P)-(1+P) \quad \text { and } \\
& \beta=\frac{\alpha+1}{P}-(\alpha+2)
\end{aligned}
$$


where

$$
\begin{aligned}
& P=\frac{(\mu-a)}{(b-a)} \quad \text { and } \\
& Q=\frac{\sigma}{(b-a)}
\end{aligned}
$$

The beta distribution can assume many shapes, depending on the values of $\alpha$ and $\beta$. Shapes include uniform, triangular, skewed left or right, and even a shape resembling a normal distribution with finite limits, as shown in Figure 2-6. The beta distribution is similar to the normal distribution when $\alpha$ $=\beta \geq 3$. Due to the complexities of beta distributions, they are not easily tabulated into a standard form such as the " $\mathrm{Z}$ " tables for the normal distribution. However, computer software is available to help with the construction of beta distributions and for calculating probabilities associated with these distributions. Harr (1987) provides the source code for this type of software.

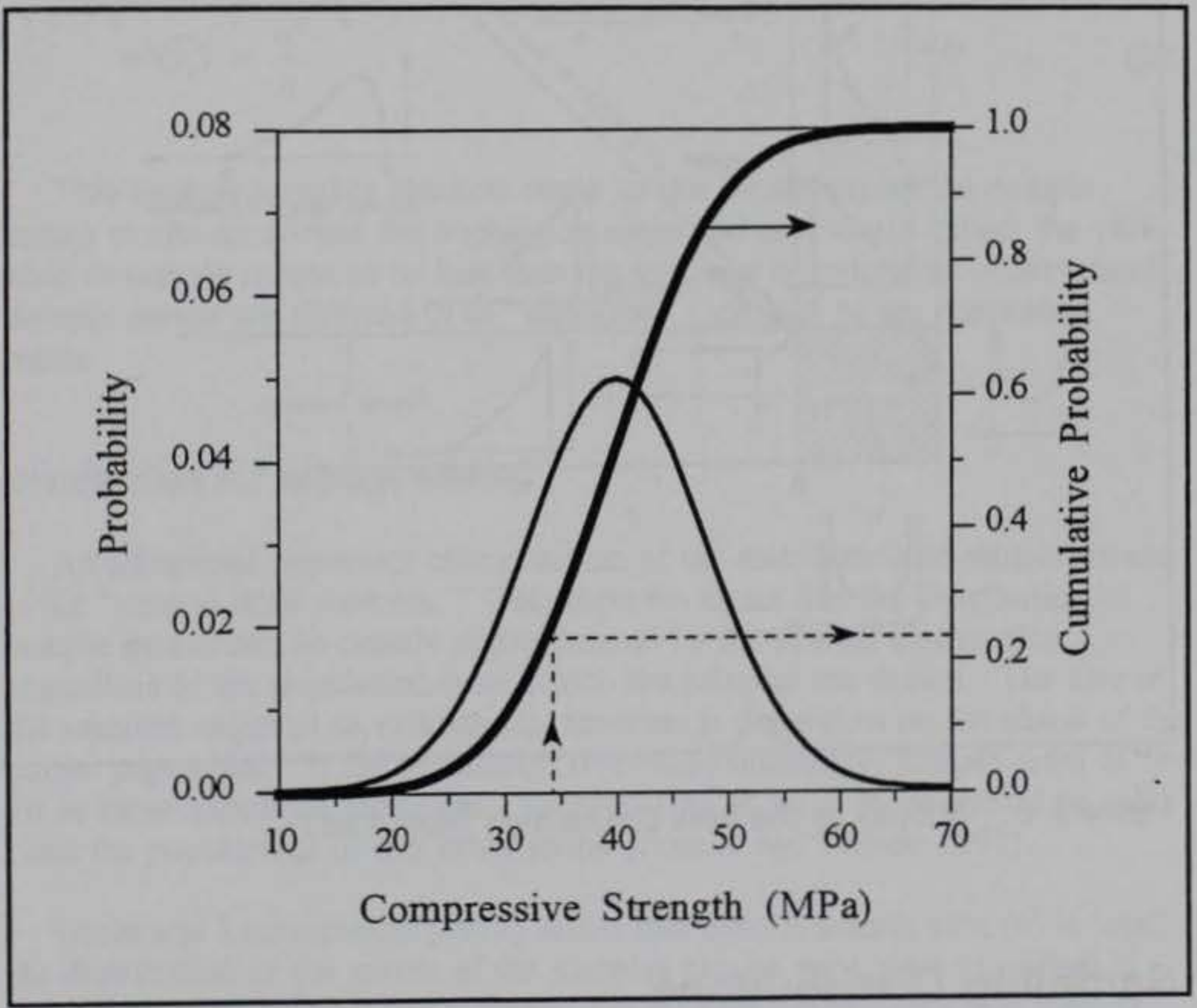

Figure 2-5. Concrete compressive strength with an assumed normal distribution 
Example. Assume that a pavement engineer is interested in load transfer between slabs that rely solely on aggregate interlock. The engineer learns from literature that for his/her slab configuration the average load transfer is approximately 20 percent. He/she also learns that the standard deviation for load transfer is typically about 10 percent. Due to the fact that measurements cannot possibly fall below zero percent or above 50 percent and due to the fact that the distribution has been reported to be skewed, the engineer may decide that a beta distribution would provide a better representation of the load transfer measurements than a normal distribution. The beta distribution and the cumulative probability distribution for this problem were calculated with Harr's (1987) software, as shown in Figure 2-7. If the engineer was interested in the likelihood that load transfer would be less than 15 percent, a quick measurement taken from the cumulative probability plot would indicate that this should occur approximately 35 percent of the time.

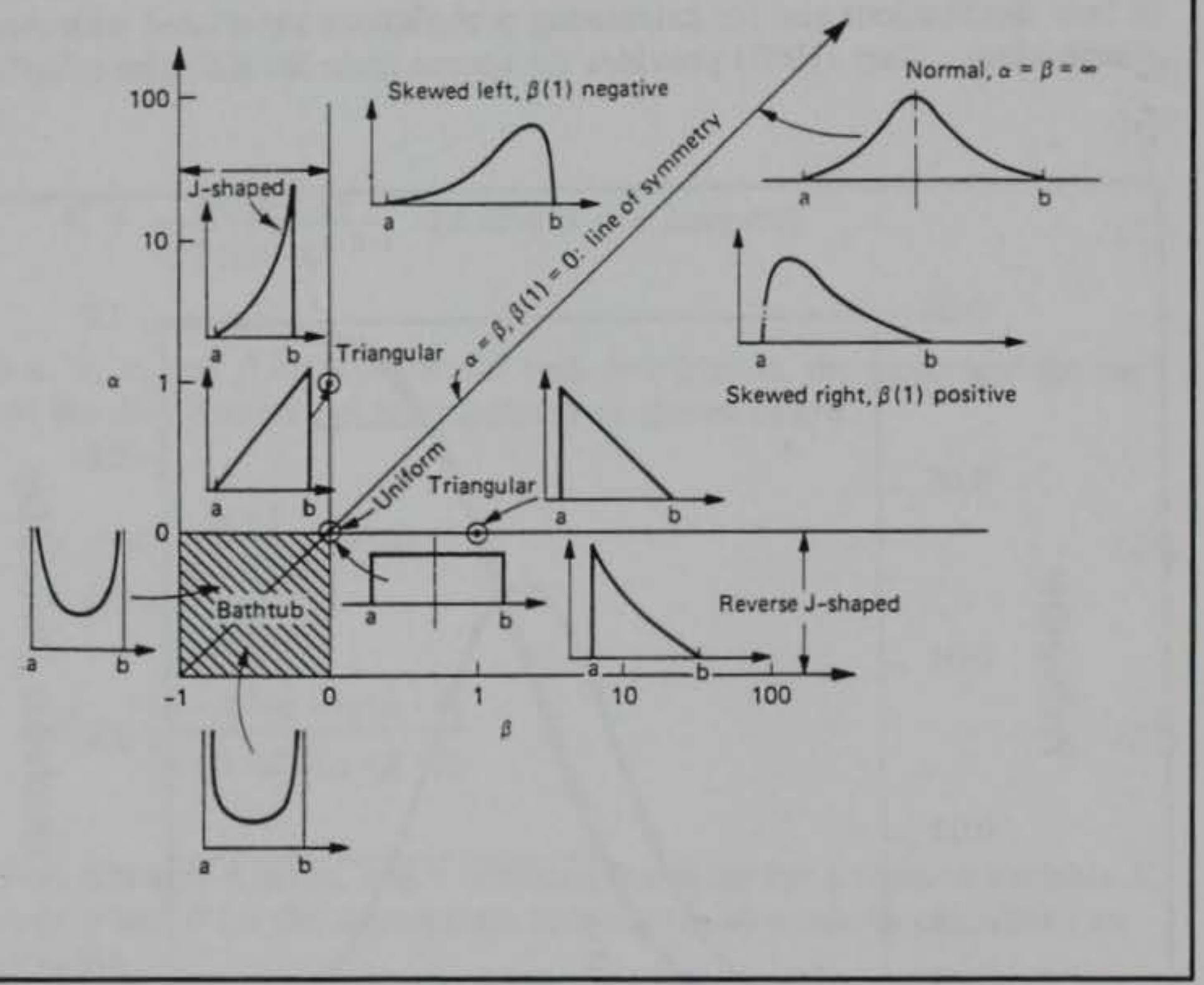

Figure 2-6. Shapes of the beta distribution (Harr 1987)

\section{Sampling Distributions}

The example problems used up to this point have included data sets that were considered to be "populations." When dealing with populations, the distribution parameters can be considered to be fixed values. When taking 
samples from a population, however, the statistics that describe the distribution of sample values cannot be considered to be fixed. Different samples taken from the same population can generate different statistics. A statistic computed from a random sample is therefore a random variable. This inherent variability for sample statistics must be considered whenever samples are used to make inferences about a population.

All the possible values of a sample statistic can be described by a probability distribution for the statistic, often called a sampling distribution. Characteristics of a sampling distribution can be related to characteristics of the population from which the samples were drawn.

Assume samples that include $n$ observations each are drawn from a population, $Y[=\{y\}]$, with mean $\mu$ and variance $\sigma^{2}$. As the number of samples drawn approaches infinity, the distribution of sample means, $\bar{y}_{1}$, will have a mean that approaches $\mu$ and a variance that approaches $\sigma^{2} / n$, as shown below.

$$
\begin{aligned}
& \mu\left(\bar{y}_{i}\right)=\mu \quad \text { and } \\
& \sigma^{2}\left(\bar{y}_{i}\right)=\frac{\sigma^{2}}{n}
\end{aligned}
$$

This statement makes intuitive sense as one would expect the sample means to cluster around the population mean and one would expect the variance of sample means to be less than the variance of individual observations. Sample means are referred to as "unbiased" estimates of the population mean.

\section{Distribution for sample means}

An additional important characteristic of the distribution of sample means is the "central limit theorem." This theorem states that the distribution of sample means can be closely approximated by the normal distribution, regardless of the population from which the samples are drawn. The size of the samples required to validate this theorem is dependent on the shape of the parent population. If the population resembles normality, sample sizes of 10 or more should be sufficient. Sample sizes of 30 or more should be sufficient for populations of any other shape (Freund and Wilson 1993).

Grant and Leavenworth (1972) stated that even if sample size (n) is small, the distribution of the means of the samples can be very close to normal if the number of samples is sufficiently large. This theory holds true even if the parent population is far from normal. Grant and Leavenworth (1972) reported on a study in which 1,000 samples of size $n=4$ were taken from two bowls: one containing numbered tags from a rectangular distribution population and one containing numbered tags from a triangular distribution 
population. Neither of the original populations resembled a normal distribution, however, the distribution of sample means in each case was normal. They reported:

"The great practical importance of the normal curve arises even more from its use in sampling theory than from the fact that some observed distributions are described by it well enough for practical purposes. Of great practical significance is the fact that distributions of averages of samples tend to be approximately normal even though the samples are drawn from nonnormal populations."

When the distribution of sample means can be assumed to be normal in shape, the standard normal variate $Z$ can be used as a problem-solving tool. Recall the transformation of a random variable from a population to a standard normal variable.

$$
z=\frac{y-\mu}{\sigma}
$$

Similarly, a sample mean can be transformed from a population to a standard normal variable:

$$
z\left(\overline{y_{i}}\right)=\frac{\overline{y_{i}}-\mu}{\frac{\sigma}{\sqrt{n}}}
$$

The denominator in Equation 35 represents the standard deviation for the distribution of sample means, which can be calculated from the variance of sample means (Equation 33), as shown below. The standard deviation of sample means is often referred to as the "standard error of the mean."

$$
\sigma\left(\bar{y}_{i}\right)=\sqrt{\sigma^{2}\left(\bar{y}_{i}\right)}=\sqrt{\frac{\sigma^{2}}{n}}=\frac{\sigma}{\sqrt{n}}
$$

Example. Suppose that an engineer is planning to construct a parking lot in an area that has a variable water table due to the presence of various types of soil. Suppose also that he/she knows from historical data that the depth to water around the site should follow a near-normal distribution. The mean and standard deviation of the depth to water is 2 meters and 0.5 meters, respectively. If the engineer is interested in the probability that a sample of 16 measurements will have a mean less than 1.75 meters, he/she can use the Z-table as shown below. 


$$
z\left(\overline{y_{i}}\right)=\frac{1.75-2}{\frac{0.5}{\sqrt{16}}}=-2
$$

From the standard $Z$ table (Appendix A), the engineer could see that the probability of getting a $z$-value less than -2 is approximately 2 percent $(0.0228)$. The engineer could then feel confident that the mean of a 16-replicate sample would very rarely be less than 1.75 meters.

For this same problem, assume the sample consists of only 4 replicates. Then the corresponding $z$-value is as shown below.

$$
z\left(\overline{y_{i}}\right)=\frac{1.75-2}{\frac{0.5}{\sqrt{4}}}=-1
$$

From the standard $z$-tables, the engineer could see that the probability of getting a $z$-value less than -1 is approximately 16 percent $(0.1587)$. With the decrease in sample size from $n=16$ to $n=4$, the standard deviation for the distribution of sample means doubled. As a result, the estimated probability for obtaining a given deviation from the mean increased.

The effects of sample size on the probability distribution for sample means is illustrated in Figure 2-8. In this figure, the distributions for sample means are shown to be more narrow (or tighter) than the standard normal distribution from which they were derived. As sample size increases, the distributions for sample means became progressively more narrow.

\section{Distribution for sample variances}

When samples of $n$ observations each are drawn from a population with mean $\mu$ and variance $\sigma^{2}$, the sample variances $s^{2}$ can be used to construct a frequency distribution. The theoretical relationship between the mean of this distribution, $\mu\left(s^{2}\right)$, and the true population variance, $\sigma^{2}$, is shown below.

$$
\mu\left(s_{i}^{2}\right)=\frac{n-1}{n} \sigma^{2}
$$

For small sample sizes, the mean of the distribution of sample variances would be less than the true population variance. However, as the sample size $n$ increases, the mean of the distribution of sample variances becomes a good estimate for the true population variance. This inequality between $\mu\left(s^{2}\right)$ and $\sigma^{2}$ causes sample variances to be termed "biased" estimates of the population variance. In order to compensate for this bias, sample variances are calculated with ( $n-1)$ as the divisor, rather than $n$ (as shown below). As the 


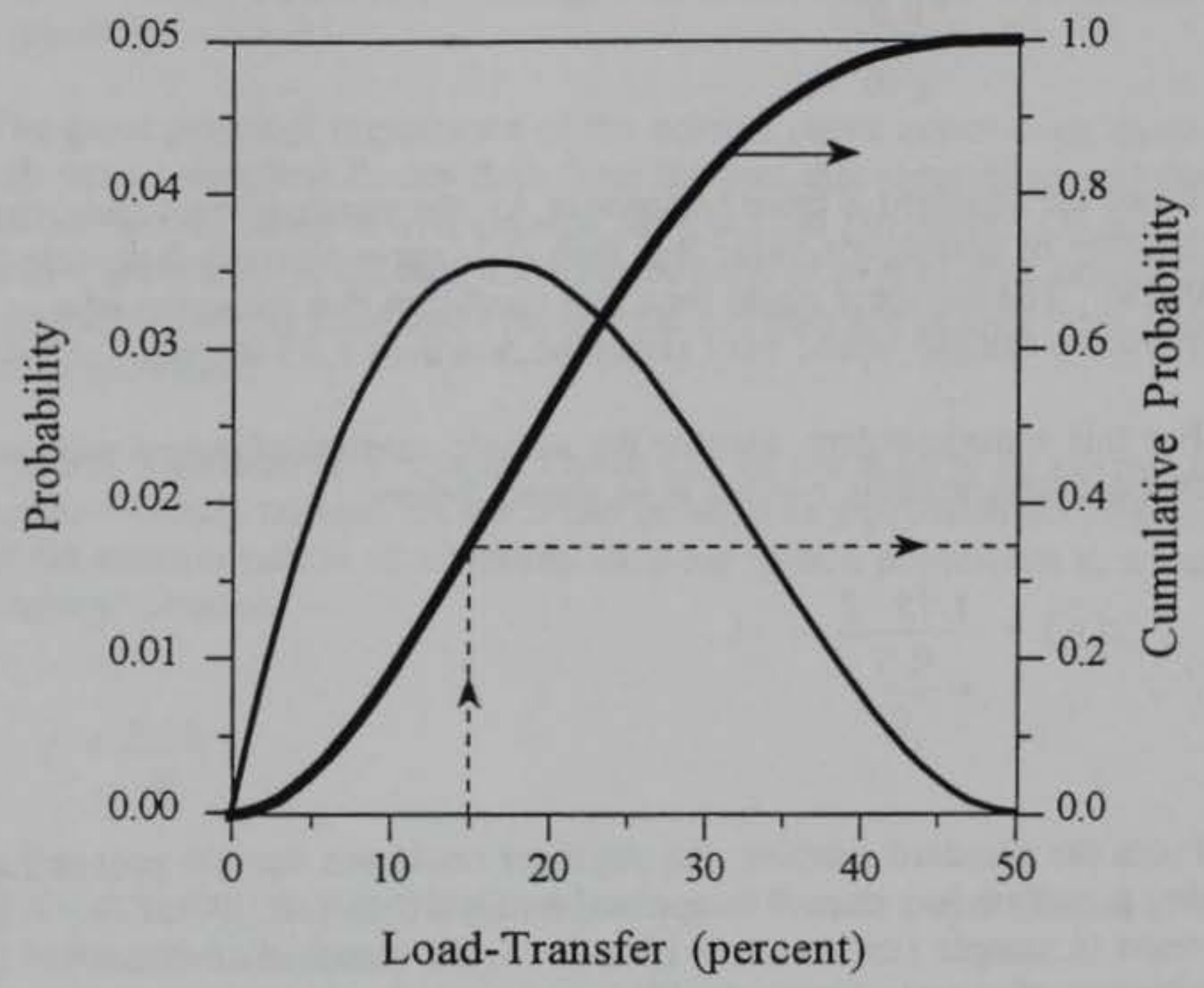

Figure 2-7. Load-transfer between pavement slabs with an assumed beta distribution

sample size $(n)$ increases, the effect of the bias, along with the magnitude of the bias correction, decreases.

$$
\text { unbiased } s^{2}=\frac{n}{n-1}\left(\text { biased } s^{2}\right)
$$

Recall the difference between the calculations for population variance $\sigma^{2}$ and sample variance $s^{2}$, as presented previously. While the divisor for population variance was $N$, the divisor for sample variance was $n-1$, as shown in Equations 41 and 42 , respectively.

$$
\sigma^{2}=\frac{\sum_{i=1}^{N}\left(y_{i}-\mu\right)^{2}}{N}
$$




$$
s^{2}=\frac{\sum_{i=1}^{n}\left(y_{i}-\bar{y}\right)^{2}}{n-1}
$$

The term $n-1$ in these calculations for sample variance can be referred to as the degrees of freedom for the sample variance statistic. In general, the degrees of freedom for a statistic $(v)$ is defined as the number of independent observations $(n)$ minus the number of population parameters $(m)$ that must be estimated from sample observations in order to calculate the statistic. In symbols, $v=n-m$ (Spiegel 1990).

As shown previously, the calculation for sample variance requires an estimate for the population mean $(\mu)$, which is provided by the sample mean $(\vec{y})$. Therefore, the degrees of freedom for sample variance can be calculated as $v=n-m=n-1$.

\section{$T$ distribution}

In previous applications of the $Z$ tables, the standard deviation of the population $(\sigma)$ was assumed to be known. In most practical situations, however, $\sigma$ is not known and the only available measure of the population standard deviation is the sample standard deviation $(s)$. In order to make continued use of the standard normal tables for sample mean distributions, one would like to substitute $s$ for $\sigma$ in the calculation of $Z$. This substitution can be made, but the resulting distribution is not exactly normal and has to be handled differently than the $Z$ distribution. If $s$ substitutes for $\sigma$, the distribution is referred to as a $t$ distribution (or Student's $t$ ). The calculation of $t$ is performed as shown in Equation 43. The $t$ distribution is similar to normal in that it is bell-shaped and symmetric about its mean. Relative to normal, however, the $t$ distribution is broader (has fatter tails). This breadth reflects increased dispersion for the variate, which is caused by the uncertainty of using a sample statistic to estimate the population standard deviation. As the sample size increases, confidence in the estimate of the population standard deviation increases, causing the $t$ distribution to become more narrow and to approach normality (Baecher 1987), as shown in Figure 2-9.

$$
t=\frac{\bar{y}-\mu}{\frac{s}{\sqrt{n}}}
$$

The probability density function that describes the $t$ distribution is tedious to integrate manually, so problems are typically solved with the help of computer software or standard $t$ tables, such as that shown in Table A2 (Appendix A). 


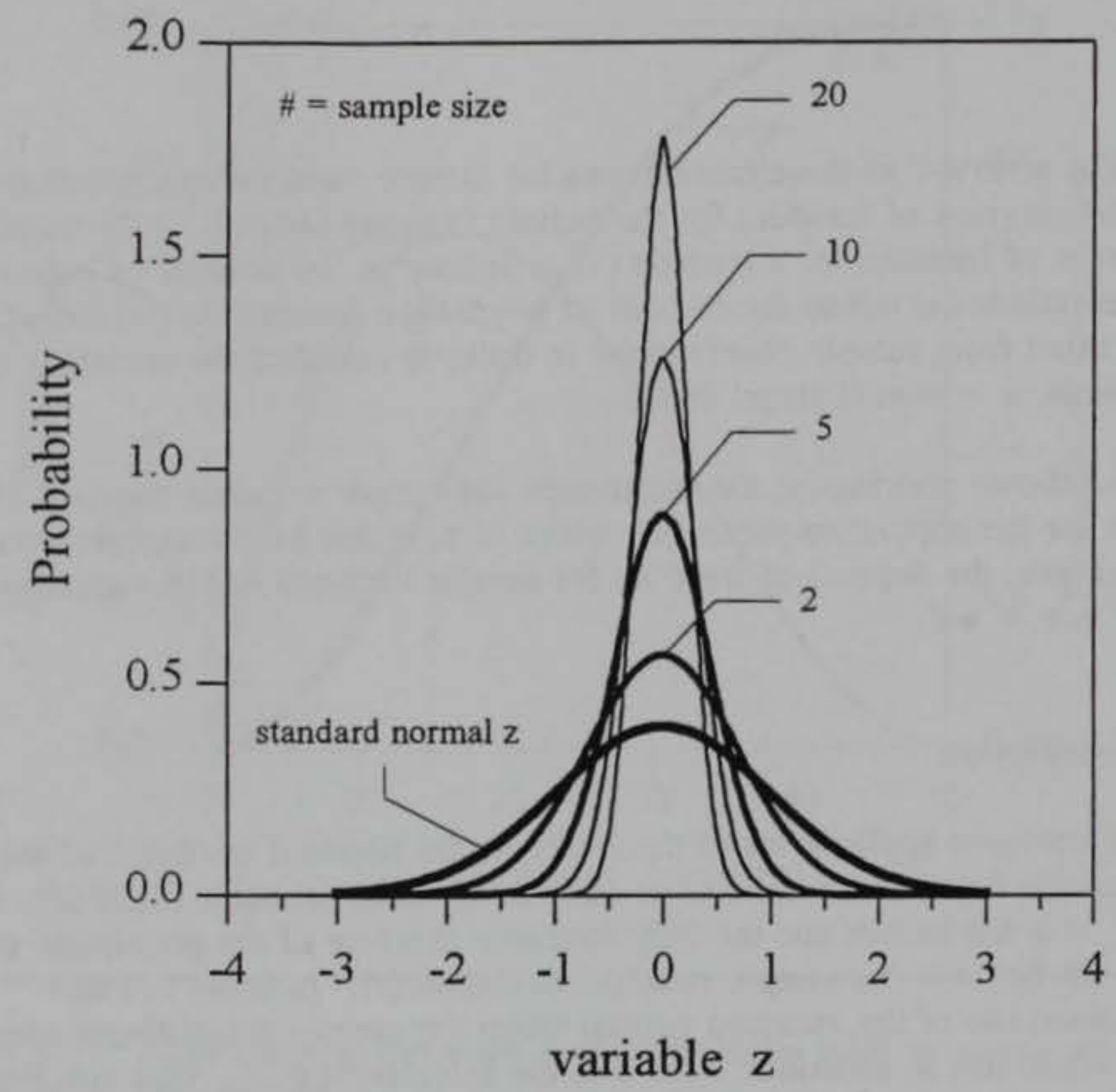

Figure 2-8. Effect of sample size on the probability distribution for sample means

\section{Chi-squared $\left(x^{2}\right)$ distribution}

The $\chi^{2}$ distribution provides a method for comparing sample variances with population variances. If $\chi^{2}$ is calculated for one or more samples taken randomly from a parent normal population, then $\chi^{2}$ also becomes a random variable. Chi-square can be defined for each sample as shown below.

$$
\chi^{2}=\frac{S S}{\sigma^{2}}=\frac{\sum_{i=1}^{n}\left(y_{i}-\bar{y}\right)^{2}}{\sigma^{2}}
$$

where

$$
y_{i}=\text { each value within a sample }
$$


$\bar{y}=$ the calculated mean for the sample

$S S=$ sum of squared deviations for the sample data

$\sigma^{2}=$ the variance for the parent population

$n=$ the number of values obtained for the sample

The relationship between sample variance and population variance(Equation 3), contained within the $\chi^{2}$ variable, can be seen more clearly with a different expansion on the sum-of-squares term. Recall the definition for the unbiased estimate of population variance, calculated from a sample of data: $s^{2}=S S /(n-1)$. Substitution of this relationship for the sum-of-squares in Equation 44 provides the following formula for $\chi^{2}$.

$$
\chi^{2}=\frac{(n-1) s^{2}}{\sigma^{2}}
$$

The probability density function that describes a $\chi^{2}$ distribution is tedious to integrate manually, so software or published tables, such as that shown in Table A3 (Appendix A), are often used. Similar to the variances from which they are calculated, $\chi^{2}$ values cannot be negative. The $\chi^{2}$ distribution can be other than normal and its shape is dependent on the number of values obtained for the sample $(n)$, as shown in Figure 2-10.

A few important characteristics of the chi-square distribution are listed below (Freund and Wilson 1993).

$a$. The mean of the $\chi^{2}$ distribution is equal to the degrees of freedom, $v$ $(=n-1)$, and the variance is equal to $2 v$.

$b$. For large values of $v$ (usually greater than 30 ), the $\chi^{2}$ distribution can be approximated by the normal distribution with a mean and variance as described in "a." Thus, in these cases, the standard normal distribution can be used as shown below.

$$
z=\frac{\chi^{2}-v}{\sqrt{2 v}}
$$

c. The accuracy with which $\chi^{2}$ represents $S S / \sigma^{2}$ for samples is not significantly affected when the parent population deviates slightly from normal. Severe departures from normality, however, can affect the reasonableness of using $\chi^{2}$.

Example. Suppose that an agency is monitoring asphalt cement content for a paving job. If a sample of 10 measurements had a variance of 0.04 percent $^{2}$ and the variance had historically been 0.03 percent $^{2}$, what would be the probability of obtaining a sample variance of 0.04 percent or 


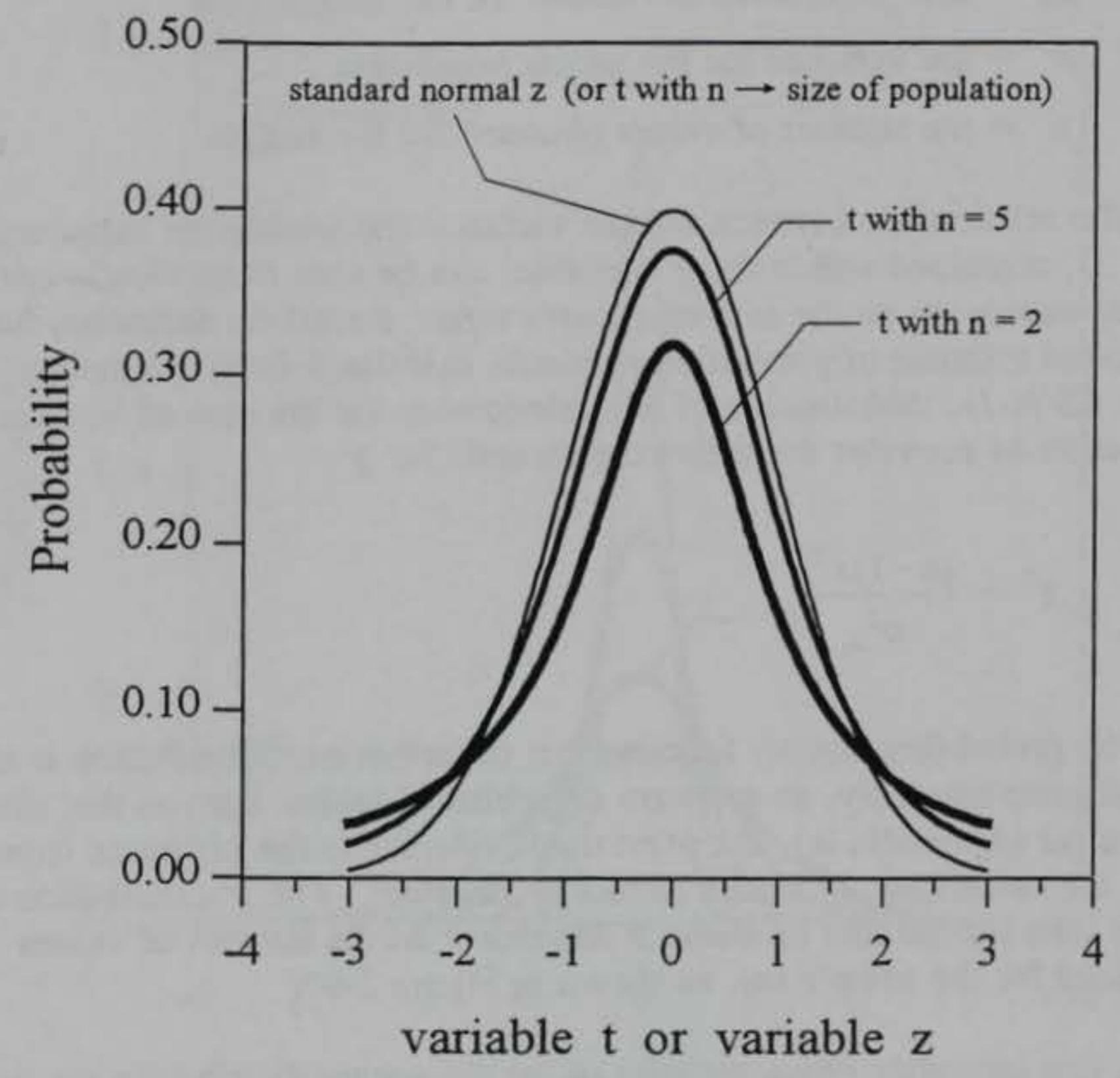

Figure 2-9. Effect of sample size on the probability distribution for student's $t$

higher? The $\chi^{2}$ calculation is illustrated in Equation 47. Degrees of freedom is nine $(10-1)$.

$$
\chi^{2}=\frac{(10-1) 0.04}{0.03}=12
$$

From the $\chi^{2}$ distribution (Table A3) and linear interpolation, the probability of obtaining a $\chi^{2}$ value of 12 or higher is found to be approximately 22 percent $(0.2227)$. The evidence should suggest to the agency that this sample variance is not highly unlikely. Based on this data alone, there is no reason to judge that the manufacturing process for asphalt concrete is out of control. 


\section{$F$ distribution}

The $F$-statistic is defined as the ratio of two independent $\chi^{2}$ random variables, each divided by their respective degrees of freedom. Assume that $s_{1}{ }^{2}$ and $s_{2}{ }^{2}$ are the variances of two independent samples of size $n_{1}$ and $n_{2}$, respectively. If these samples are taken from the same population or from two different populations with variances that are expected to be equivalent, then $F$ can be calculated as shown below.

$$
F=\frac{s_{1}^{2}}{s_{2}^{2}}
$$

The choice for which variance estimate to place in the numerator is somewhat arbitrary. Typically, reference tables for the distribution of the F-statistic assume that the larger variance is used as the numerator. Since the samples from which variances are calculated are selected randomly, $F$ is also a random variable. Similar to the $\chi^{2}$ probability distribution, the $F$ distribution is defined only for positive values. The shape of the $F$ distribution is dependent on the degrees of freedom for each of the sample sets from which variance was calculated.

The probability density function for the $\mathrm{F}$ distribution is complex and would be difficult to integrate manually. Similar to other sampling distributions, the use of software or reference tables, such as that shown in Table A4 (Appendix A), are essential.

The $F$ distribution is nonsymmetric, particularly when one or both of the distribution parameters has a low value. Figure $2-11$ shows $F$ distributions when the number of replicates for each sample are equal and consist of values ranging from 5 to 50 . Figure $2-12$ shows the effect on the $F$ distribution when the number of replicates for one of the samples drops from 50 to 5 .

The $F$ distribution is used to conduct analysis-of-variance (ANOVA) procedures, which will be demonstrated in the next chapter. The $F$ distribution can also be used to make simple inferences concerning the equality of variances for two normal populations.

Example. Suppose that two construction crews (A and B) are placing . asphalt concrete surface course mixtures. Suppose further that 21 randomly located cores were removed from crew A's pavement while 11 randomly located cores were removed from crew B's pavement. The standard deviation for surface course thickness was determined to be $5 \mathrm{~mm}$ and $3 \mathrm{~mm}$, respectively. If the two crews should be paving with equal uniformity in thickness, what is the probability of finding a difference in standard deviations as large or larger than that measured? 


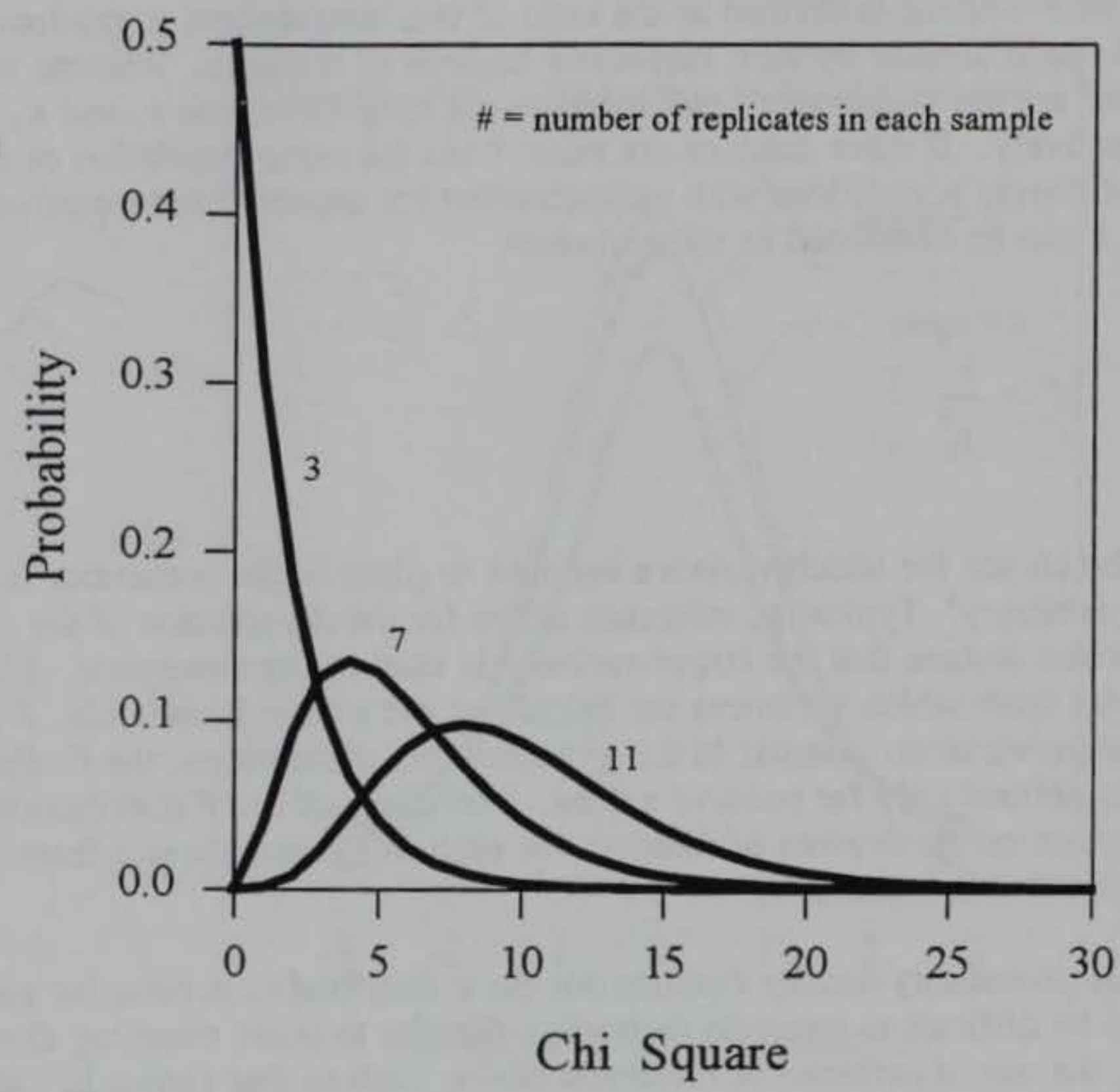

Figure 2-10. Effect of sample size on the chi-square distribution

The F-statistic is calculated as shown in Equation 49. The value 2.8 is compared to values provided in the standard $F$ distribution table, with degrees of freedom equal to 20 and $10, F(20,10)$. Using linear interpolation within Table A4, the probability of obtaining a ratio of variances this large is found to be less than 5 percent $(0.0488)$. The variances can therefore be considered significantly different with a high degree of confidence. The project manager can feel confident that the pavement placed by crew B has a more uniform thickness than the pavement placed by crew $\mathrm{A}$.

$$
F=\frac{s_{A}^{2}}{s_{B}^{2}}=\frac{(5)^{2}}{(3)^{2}}=2.8
$$




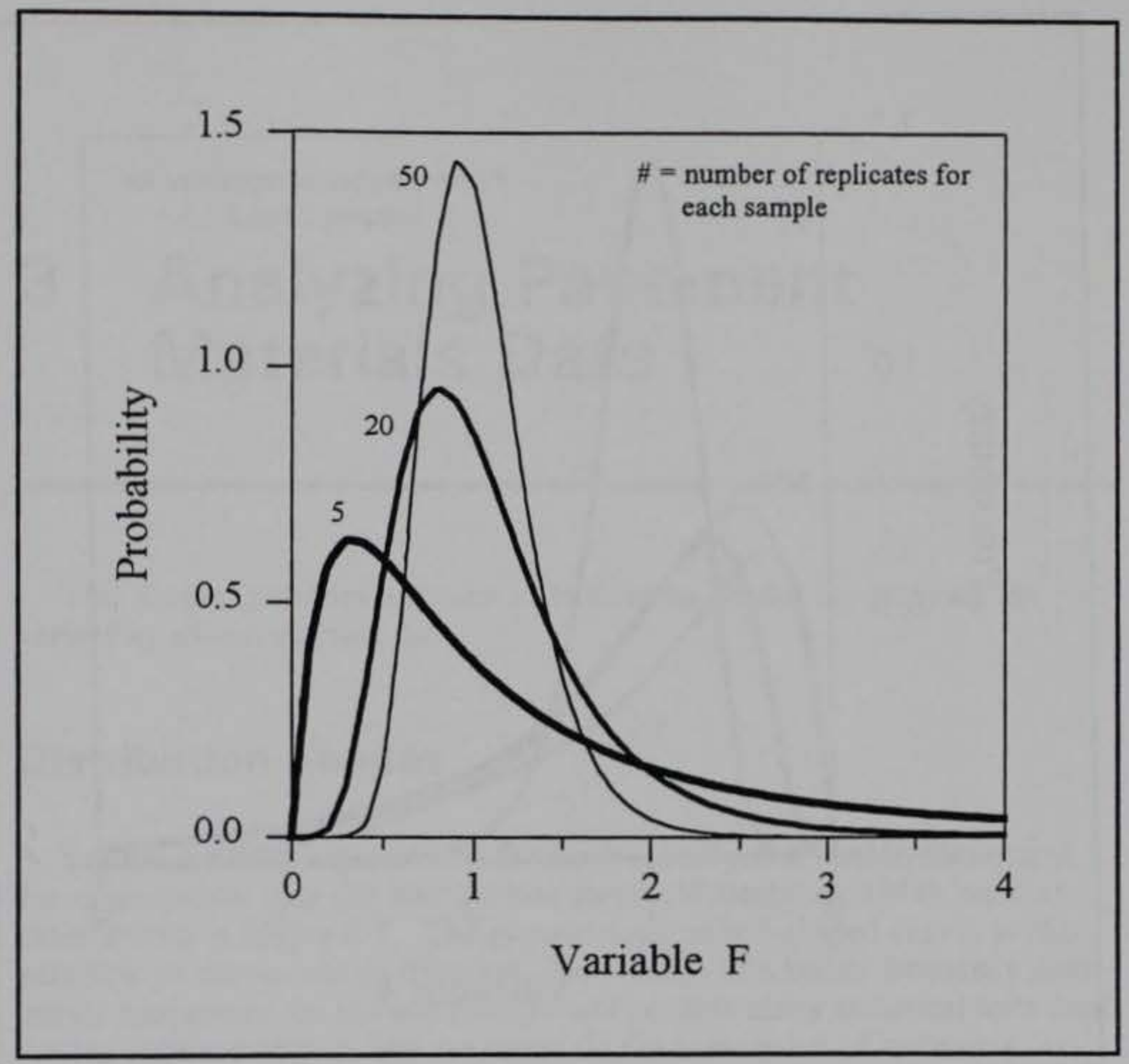

Figure 2-11. Effect of sample sizes on the $F$ distribution 


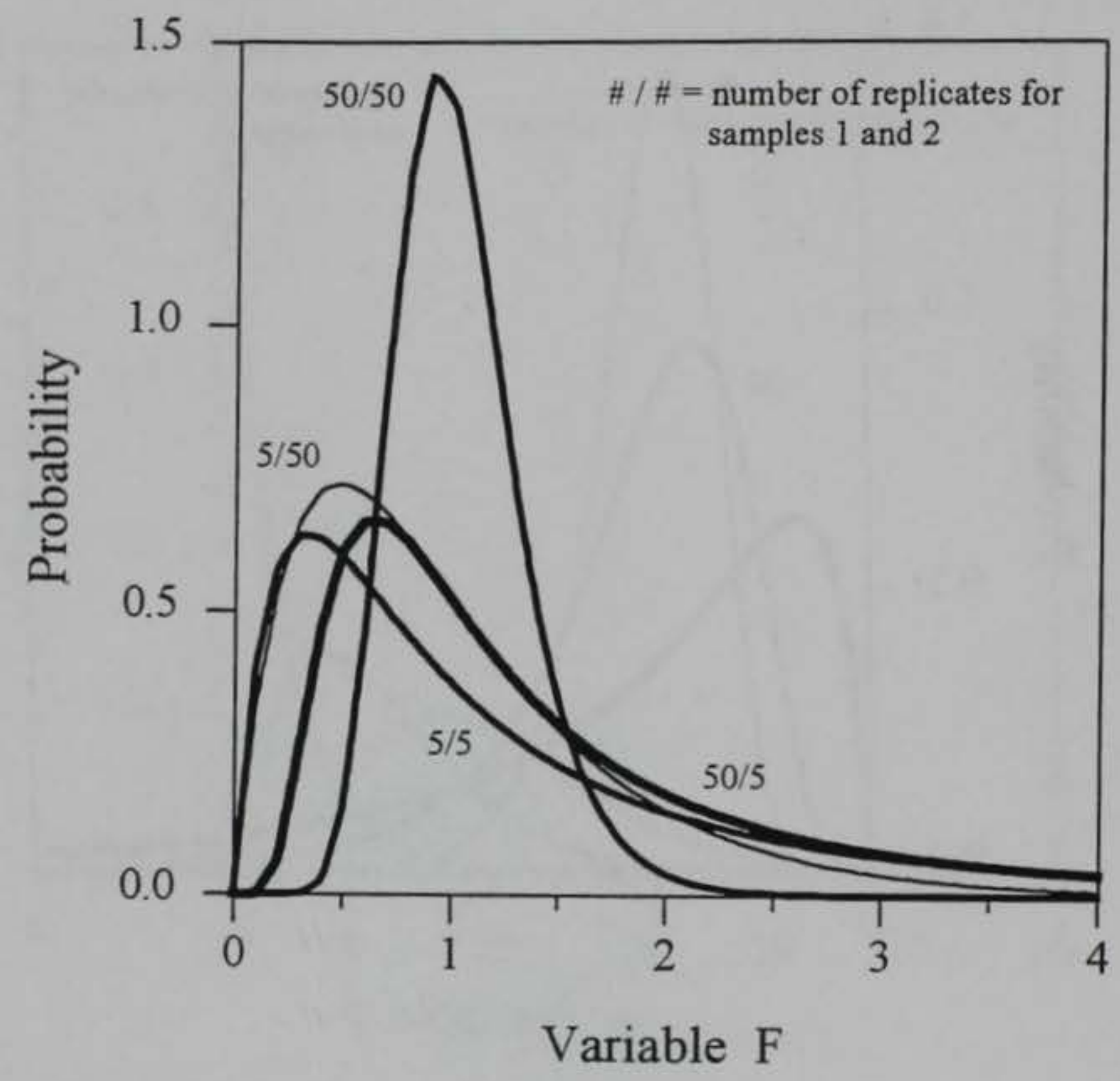

Figure 2-12. Effect of unequal sample sizes on the $F$ distribution 


\section{Analyzing Pavement Materials Data}

This chapter provides a review of techniques needed for studying the variability of construction data.

\section{Distribution Shapes}

Smooth curve approximations for the frequency distribution histograms for experimental data can take various forms (Willenbrock 1974), such as those shown in Figure 3-1. The symmetrical, or bell-shaped curve, is characteristic of the normal distribution. Knowledge of whether frequency distribution histograms are skewed is important because many statistical tests used for the interpretation of data are based on the assumption of symmetry, or even normality. The J-shaped and U-shaped distributions shown in Figure 3-1 are not common in cases for construction materials unless data has been manipulated. For example, compressive strength data for concrete can be reverse J-shaped if all strengths less than the specificied strength are discarded.

Symmetric and skewed distributions are examples of unimodal (single peak) distributions. Distributions can also be bimodal or multimodal if more than one peak exists. These characteristics have serious implications for statistical analyses because the sample of data has probably not been obtained from a single population. In a bimodal distribution, each of the two peaks may represent the mean of a different population.

The overriding pattern for the frequency distribution histograms for construction materials (e.g. quality control data) is that they tend toward bellshaped curves, rather than J-shaped, U-shaped, or multimodal curves (Willenbrock 1974). When variability among data is caused by the cumulative effect of a large number of small perturbations or errors, the resulting frequencies of observations typically exhibit a near-normal distribution, which is bell-shaped (Baecher 1987, Benjamin and Cornell 1970). Even when the material property of interest does not have a normal frequency distribution, the frequency distribution of sample means is approximately normal (Baecher 1987). This idea is an element of the central limit theorem, as discussed in the previous chapter. 

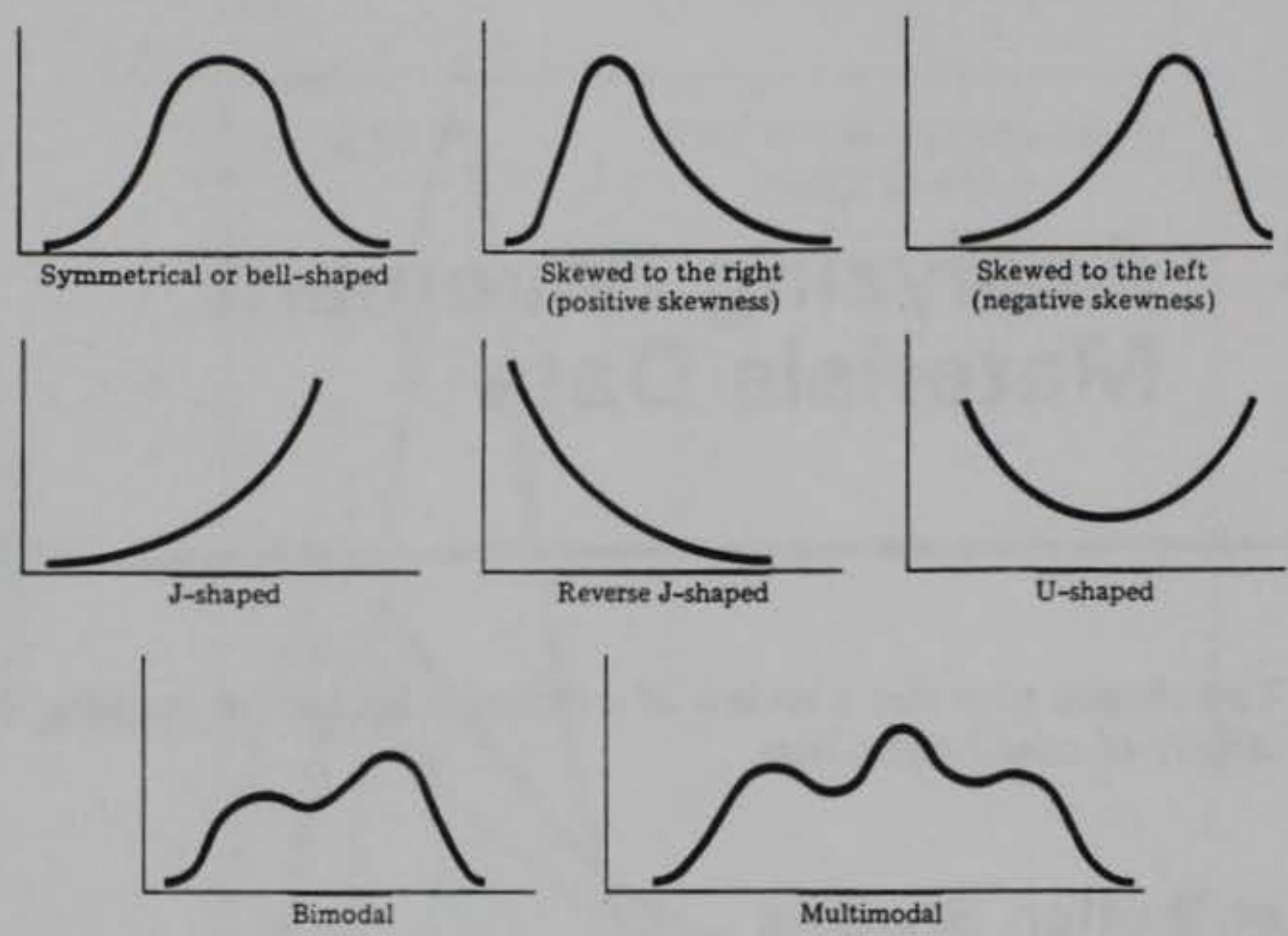

Figure 3-1. Characteristic shapes of smooth-curve approximations for frequency distributions (Spiegel 1988)

\section{Departures From Normality}

For the case where the frequency distribution for pavement materials data departs form the "normal" shape, the cause is probably one of the following (Rethati 1983):

a. Physical limits.

b. Errors caused by sampling and testing.

Physical limits means that the possible numerical values for a measured material property have either an upper limit, a lower limit, or both (Rethati 1983). For example, unconfined compressive strength for soil cannot be less than zero, so the results for low-strength soils would tend to have a positive skew. Physical limits that are not near the mean of a material property would tend not to induce skewness. The unconfined compressive strength of concrete cannot be less than zero, but average strengths are typically so far removed from zero that skewness is not induced by this numerical boundary. An example of potential negative skew occurs for measured degree of saturation for wet soil. If the mean degree of saturation is relatively large (greater than 60 percent), the distribution would tend to end abruptly at the physical limit of 100 percent. 
To attain normality, the data forming a frequency distribution must typically come from a single population (Rethati 1983). If the material is concrete, all the concrete must be from the same mixture design. If the material is soil, horizontal and vertical survey boundaries must be employed so that the soil can be considered a single deposit. If two different types of soil are analyzed as a single population, a sampling error would have been committed, and the distribution for a material property may likely appear bimodal. If the property is plasticity index (PI) and the two soil types are clays of different plasticity, the measurements of one soil type may cluster around a PI of 30 (for example), while the measurements of the second soil type may cluster around a PI of 20 . In order to evaluate this data properly, the two soil types should be treated as two different populations.

Additional sampling errors can be caused by deviations in the time of sampling. Time can permit changes in material properties, which can invalidate assumptions concerning the material's homogeneity, including the assumption that all the samples come from the same population (Rethati 1983). If the material is a silt soil and the measured property is moisture content, a day's difference in sampling time provides an opportunity for moisture content to change. If the material is an asphalt concrete and the measured property is temperature, measurements just after loading a truck should be considered a separate population from measurements upon arrival at the construction site.

Errors caused by testing can skew results (Rethati 1983). For soil, the level of disturbance imposed on a sensitive clay during sampling will affect shear strength measurements. If some of the samples are severely disturbed, they will exhibit lower strengths, which will cause the distribution to skew in the negative direction. If some concrete cylinders are allowed to dry before measuring compressive strength, their measured strength will be high, which will cause the distribution to skew in the positive direction.

\section{Tests for Normality}

Many common statistical procedures assume that the frequency distribution of data is Gaussian, or normal. It is important to know when incorrect assumptions for normality can lead to gross errors and to know how to check for normality. Incorrect assumptions concerning the shape of probability distributions are most critical when the statistical analysis is concerned with the "tails" of the distribution, or the very low and very high values (Coleman and Steele 1989). For example, the use of statical methods for the determination of outliers in a data set involves the tails specifically. These methods are sensitive to the shape of the probability distribution. Statistical methods that use the entire body of data, such as methods for comparing sample means, are less sensitive to the shape of the probability distributions.

The simplest method for determining whether or not a sample frequency distribution is normal involves visual inspection of the shape of its histogram. 
If the histogram is symmetric and bell-shaped, the assumption of normality is probably acceptable.

The next level of sophistication for testing normality is another graphical alternative, involving the production of a "normal probability plot." Several types of normal probability plots exist, but they all share a common characteristic: a distribution that is normal or nearly normal will plot as a straight line, extending from the lower left quadrant to the upper right quadrant (Willenbrock 1974c). Examples of these plots will be shown as part of an example problem later in this chapter. A popular style used by statistical software packages is to format the $\mathrm{x}$ - and $\mathrm{y}$-axes as unitless linear scales. The $x$-axis is used for representing all real data in terms of standard deviations from the mean. The $y$-axis is used for representing standard normal values $(Z)$, obtained using the cumulative percent frequencies for the data. For example, if an observation is greater than 50 percent of the entire data set, its expected normal $Z$ would be 0.0 (Table $A 1$ ). If an observation is greater than 80 percent of the entire data set, its expected normal $Z$ would be approximately 0.84 . If the data is normal, its calculated standard deviations from the mean should correlate positively with the standard normal deviations from the mean (Norusis 1993). These plots are typically referred to as $Z$-plots. An example problem is used later in this chapter to demonstrate the construction of a Z-plot.

Another version of the normal probability plot uses linear scales for the xand $y$-axes, with percent as their units. The $x$-axis is used to represent cumulative percent frequencies for the actual data. Each data point is converted to standard deviations from the mean and this value is used in the standard normal $Z$ table to obtain an expected cumulative percent frequency, which is plotted on the $y$-axis. If the data is normal, its calculated cumulative percentages should correlate positively with the standard normal cumulative percentages (Norusis 1993). These plots are typically referred to as P-plots. An example problem is used later in this chapter to demonstrate the construction of a P-plot.

Several methods exist for purely quantitative testing of normality. Collectively, these methods are referred to as "goodness-of-fit" tests. In each method, the decision of normality is reduced to statistical testing of the null hypothesis, which states that the distribution is normal in shape. Rejection or acceptance of this hypothesis involves a comparison between a calculated statistic and a test statistic. These methods include the chi-square $\left(\chi^{2}\right)$ test, the Kolmogorov-Smirnov test, the Lilliefors test, and the Shapiro-Wilks test. These methods vary in terms of their leniency towards rejecting the null hypothesis of normality. It is important to realize that as data sets become large, each of these goodness-of-fit tests becomes hard to satisfy (Norusis 1993). Frequency distributions for real-world data will rarely exhibit perfect normality, even if they appear to be symmetric and bell-shaped.

In order to account for the inherent strictness of normality testing for large datasets, the probability for falsely rejecting normality should be decreased, essentially making the normality test more lenient. The probability of falsely rejecting normality is controlled by setting a level of test 
significance $(\alpha)$. Practitioners who test for normality by these quantitative methods should supplement their results with normal probability plots. This practice will enable the practitioners to develop a sense of the relationship between dataset size, normality, and appropriate level of test significance $(\alpha)$.

Example. The $\chi^{2}$ "goodness-of-fit" test is demonstrated in this example because it is commonly used and it is simple. The data are moisture content determinations for a residual, high-plasticity clay (Table 3-1). There are 229 measurements, with a mean of 31.9 percent and a standard deviation of 12.8 percent. To begin a chi-square test, the data are categorized into intervals, as if producing a frequency distribution plot. Distances of the intervals from the mean are determined from the upper end of the intervals and are expressed in terms of standard deviations. This is necessary so that the actual data can be compared to expected values obtained from the standard normal table (Table A1). The standard normal table provides the probability of obtaining a sample value within each class interval, if the data was normally distributed. Expected observation frequencies for each class interval, assuming normality, can then be obtained by multiplying each class interval probability by the total number of observations. The contribution to chisquare from each class interval is calculated as:

$$
\chi^{2} \text { contribution }=\frac{(\text { observed }- \text { expected })^{2}}{\text { expected }}
$$

The total $\chi^{2}$ is then the sum of all the class interval contributions. For this example, the total chi-square (sum of column F) was 10.52 .

The degrees of freedom for chi-square is the total number of class intervals $(k)$ minus one, minus the number of independent population parameters estimated $(m)$. The subtraction of one from $k$, in addition to subtracting $m$, accounts for a constraint condition. The constraint states that if $k-1$ expected frequencies are known, the remaining frequency can be determined (Spiegel 1990). For this example, there were 14 class intervals and we estimated two population parameters: mean $(=31.9$ percent) and standard deviation (=12.8 percent). Therefore, we had 11 (14-1-2) degrees of freedom. From Table A3, we can determine the probability of obtaining a chi-square larger than 10.62 if the population was normal. Using linear interpolation, we find this probability to be 0.48 or 48 percent. Therefore for this example we cannot reject the assumption of normality. The assumption of normality should be rejected only if the probability of obtaining a $\chi^{2}$ larger than the calculated value is less than the established level of significance. For this example, if the level of significance had been set at 5 percent, the assumption of normality could only have been rejected if the probability of obtaining a $\chi^{2}$ larger than the calculated value was less than 5 percent.

Using the same set of data, values for both a Z-plot and a P-plot were calculated, as shown in Table 3-2. Values for these plots can be obtained using either individual data points or class intervals. Statistical software packages will typically use all the data points. For simplicity, the class intervals were 


\begin{tabular}{|c|c|c|c|c|c|c|}
\hline \multicolumn{7}{|c|}{$\begin{array}{l}\text { Table 3-1 } \\
\text { Goodness-of-Fit for Moisture Contents (Percent) of Residual, } \\
\text { High-Plasticity Clay (adapted from Steel and Torrie 1980) }\end{array}$} \\
\hline Class Interval & A & B & c & D & E & $\mathrm{F}$ \\
\hline 0.6 to 5.5 & 7 & -26.43 & -2.065 & 0.0194 & 4.44 & 1.48 \\
\hline 5.6 to 10.5 & 5 & -21.43 & -1.674 & 0.0277 & 6.34 & 0.28 \\
\hline 10.6 to 15.5 & 7 & -16.43 & -1.284 & 0.0525 & 12.0 & 2.08 \\
\hline 15.6 to 20.5 & 18 & -11.43 & -0.893 & 0.0863 & 19.8 & 0.16 \\
\hline 20.6 to 25.5 & 32 & -6.43 & -0.502 & 0.1219 & 27.9 & 0.60 \\
\hline 25.6 to 30.5 & 41 & -1.43 & -0.112 & 0.1477 & 33.8 & 1.53 \\
\hline 30.6 to 35.5 & 37 & 3.57 & 0.279 & 0.1545 & 35.4 & 0.07 \\
\hline 35.6 to 40.5 & 25 & 8.57 & 0.670 & 0.1386 & 31.7 & 1.42 \\
\hline 40.6 to 45.5 & 22 & 13.57 & 1.060 & 0.1068 & 24.5 & 0.26 \\
\hline 45.6 to 50.5 & 19 & 18.57 & 1.451 & 0.0712 & 16.3 & 0.45 \\
\hline 50.6 to 55.5 & 6 & 23.57 & 1.841 & 0.0405 & 9.27 & 1.15 \\
\hline 55.6 to 60.5 & 6 & 28.57 & 2.232 & 0.0201 & 4.60 & 0.43 \\
\hline 60.5 to 65.5 & 3 & 33.57 & 2.623 & 0.0084 & 1.92 & 0.61 \\
\hline 65.6 to 70.5 & 1 & 38.57 & 3.010 & 0.0044 & 1.01 & 0.00 \\
\hline \multicolumn{7}{|c|}{$\begin{array}{l}A=\text { Observed frequency. } \\
B=\text { Deviation of high endpoint from mean. } \\
C=\text { Standard deviations from mean. } \\
D=\text { Normal probability of obtaining a value in the class interval (Table A1). } \\
E=\text { Expected frequency, based on normality. } \\
F=\text { Contribution to chi-square }\left[(\text { observed-expected })^{2} / \text { expected]. }\right.\end{array}$} \\
\hline
\end{tabular}

used in this example problem. The plots are shown in Figures 3-2 and 3-3. Based on the results from the $\chi^{2}$ analysis, one would expect the plots to show a strong positive correlation between the data and the standard normal values. The plots support this expectation and show that the data are at least nearly normal.

\section{Transformations}

If a data set is found not to be normally distributed, two options exist for transforming the data into a new data set that may be normally distributed. The first option is to obtain or calculate new data that have similar engineering value. For example, California bearing ratio measurements for in-situ clay may not be normally distributed, but plate-bearing load test results for the same clay may be normal in shape. 
Table 3-2

Z-Plot and P-Plot Calculations for Moisture Contents of Residual, High-Plasticity Clay (adapted from Steel and Torrie 1980)

\begin{tabular}{|c|c|c|c|c|c|}
\hline \multirow[b]{2}{*}{ Class Interval } & \multirow{2}{*}{$\begin{array}{l}\text { Observed } \\
\text { Frequency }\end{array}$} & \multicolumn{2}{|c|}{ Z-Plot } & \multicolumn{2}{|c|}{ P.Plot } \\
\hline & & $x$-axis' & $y$-axis ${ }^{2}$ & $x$-axis ${ }^{3}$ & $y$-axis ${ }^{4}$ \\
\hline 0.6 to 5.5 & 7 & -2.065 & -1.866 & 3.1 & 1.9 \\
\hline 5.6 to 10.5 & 5 & -1.674 & -1.626 & 5.2 & 4.7 \\
\hline 10.6 to 15.5 & 7 & -1.284 & -1.385 & 8.3 & 10.0 \\
\hline 15.6 to 20.5 & 18 & -0.893 & -0.986 & 16.2 & 18.6 \\
\hline 20.6 to 25.5 & 32 & -0.502 & -0.519 & 30.1 & 30.8 \\
\hline 25.6 to 30.5 & 41 & -0.112 & -0.050 & 48.0 & 45.6 \\
\hline 30.6 to 35.5 & 37 & 0.279 & 0.364 & 64.2 & 61.0 \\
\hline 35.6 to 40.5 & 25 & 0.670 & 0.678 & 75.1 & 74.9 \\
\hline 40.6 to 45.5 & 22 & 1.060 & 1.024 & 84.7 & 85.5 \\
\hline 45.6 to 50.5 & 19 & 1.451 & 1.476 & 93.0 & 92.7 \\
\hline 50.6 to 55.5 & 6 & 1.841 & 1.706 & 95.6 & 96.7 \\
\hline 55.6 to 60.5 & 6 & 2.232 & 2.120 & 98.3 & 98.7 \\
\hline 60.5 to 65.5 & 3 & 2.623 & 2.650 & 99.6 & 99.6 \\
\hline 65.6 to 70.5 & 1 & 3.010 & N/A & 100 & 99.9 \\
\hline $\begin{array}{l}1 \text { Class intervals } \\
2 \text { Normal standa } \\
\text { frequency). } \\
3 \text { Cumulative pe } \\
4 \text { Normal cumula } \\
\text { mean). } \\
\text { N/A Not applical }\end{array}$ & $\begin{array}{l}\text { resented as } \\
\text { eviation fror } \\
\text { frequency } \\
\text { frequency }\end{array}$ & $\begin{array}{l}\text { andard dev } \\
\text { he mean (t } \\
\text { a percent ( }\end{array}$ & $\begin{array}{l}\text { on from th } \\
\text { on real }\end{array}$ & $\begin{array}{l}\text { an (real } \\
\text { ulative p } \\
\text { dard de }\end{array}$ & from the \\
\hline
\end{tabular}

The second option for transforming data into a normal distribution involves recomputing all data with either a square root, a logarithm, or a trigonometric function. If a data set is lognormal in shape, taking the logarithm of all data points should create a normal distribution. Conversely, taking the logarithm of normally distributed data can cause the distribution to deviate from normality. While soil porosities (p) and void ratios (e) are often normally distributed, $\log (\mathrm{p})$ and $\log (\mathrm{e})$ are typically not (Schultze 1972). As an example of a trigonometric transformation, researchers found that the angle of internal friction $(\phi)$ for sand could be transformed into a normal distribution by applying the cotangent function (Schultze 1972).

Example. Suppose an airfield runway needs to be evaluated for its allowable passes by a fully-loaded F-15 aircraft. Suppose further that 119 estimates for allowable passes have been obtained from non-destructive evaluations using a falling-weight deflectometer. An example data set, organized by class intervals, is shown in Table 3-3. These data were evaluated 


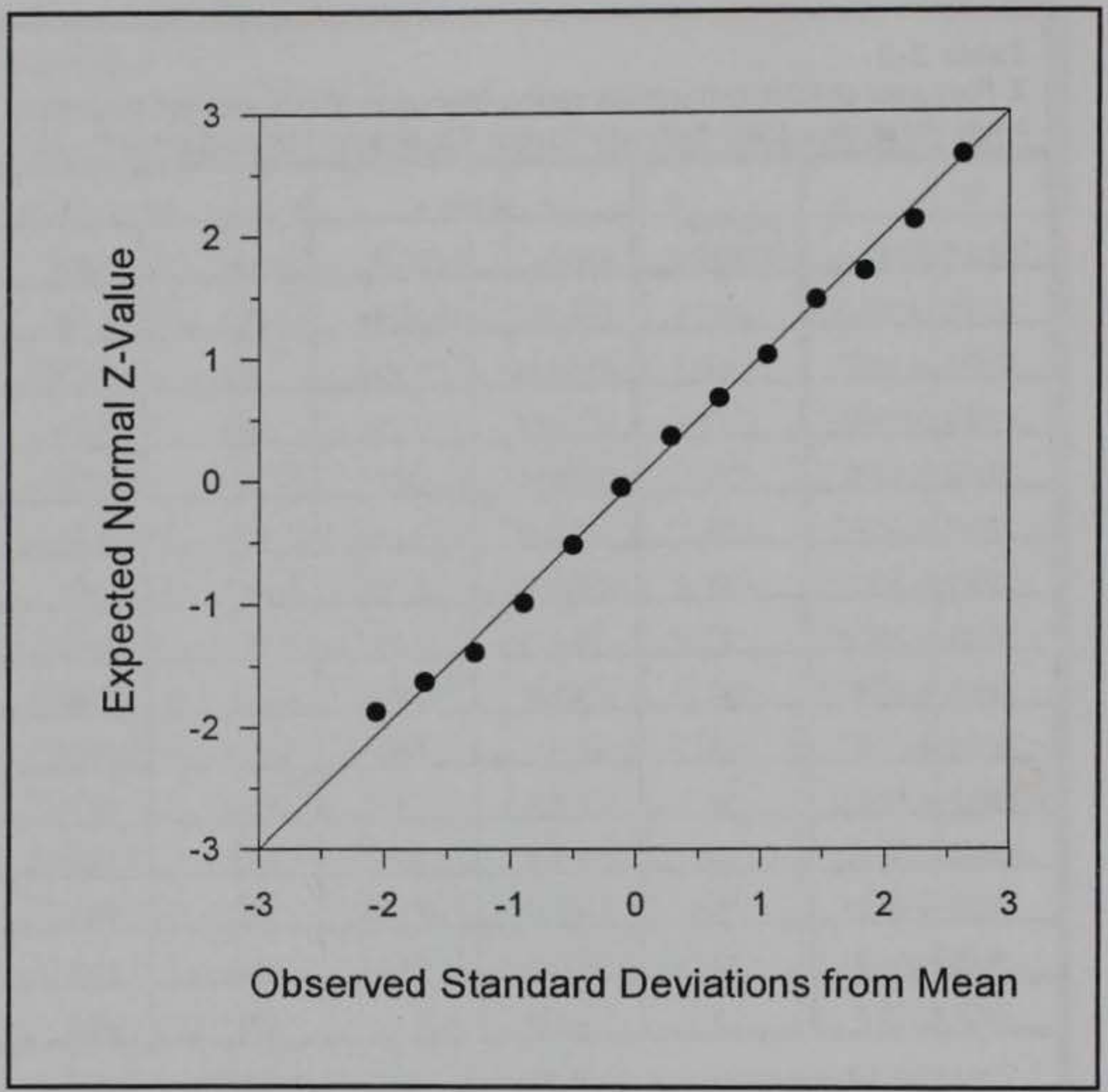

Figure 3-2. Z-Plot for a example problem concerning the moisture content of soil

for normality using both the $\chi^{2}$ test and the Kolmogorov-Smirnov test. The $\chi^{2}$ test did not reject normality, but the Kolmogorov-Smirnov test rejected normality at a significance level of 5 percent. These data, which are shown in Figure 3-6, appear to have a positive skew. This was confirmed by calculating their coefficient of skew $(=0.62)$.

Distributions for allowable passes are often lognormal in shape, so transformations using the logarithmic function can often improve normality. The transformed allowable passes data are also shown in Table 3-3. Neither the $\chi^{2}$ test or the Kolmogorov-Smirnov test rejected normality for these transformed data. These data, which are shown in Figure 3-7, do not appear to have any significant skew. This was confirmed by calculating their coefficient of skew $(=-0.07)$. 


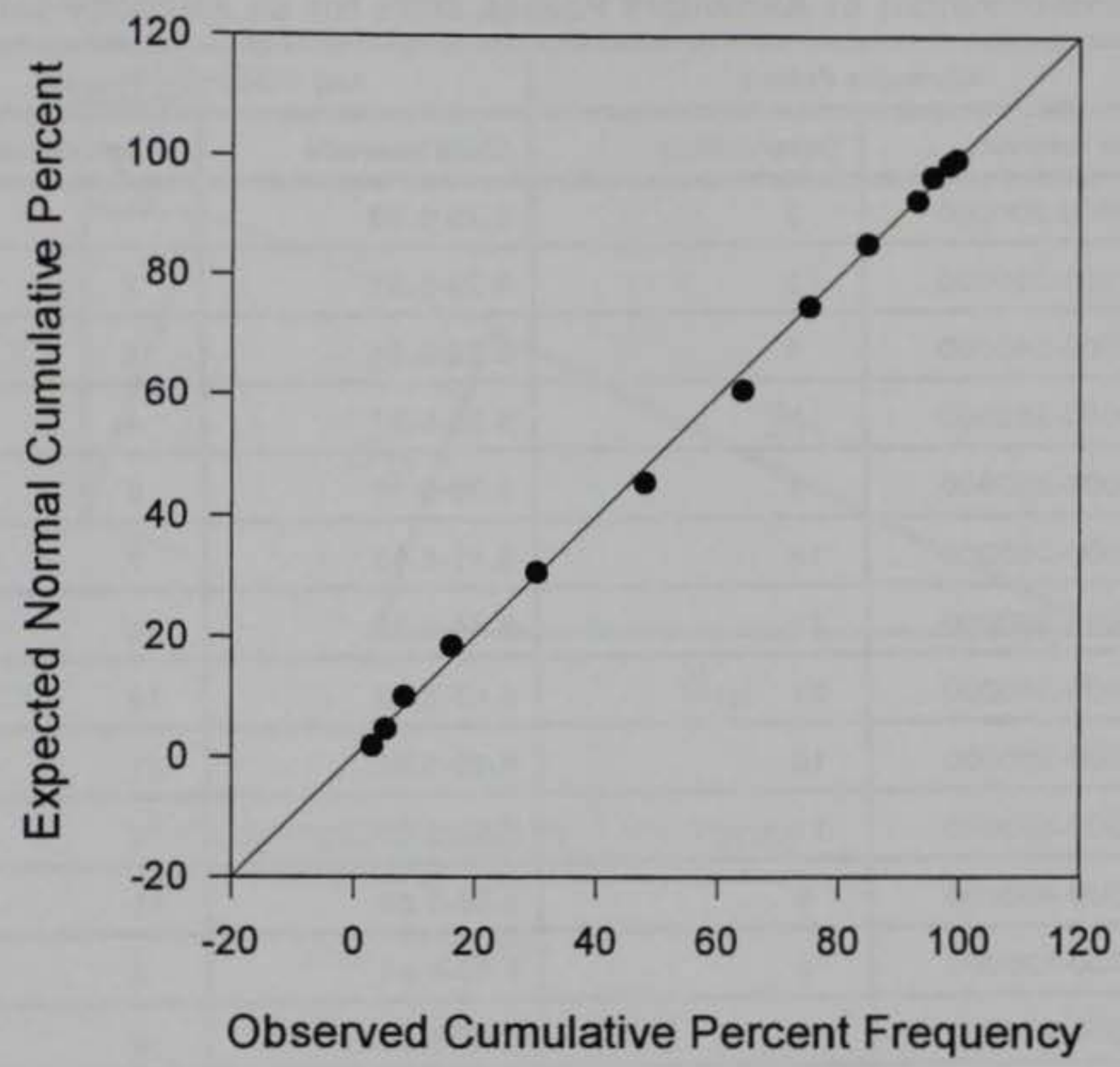

Figure 3-3. P-Plot for an example problem concerning the moisture content of soil

\section{Handling Potential Outliers}

In handling large quantities of data, some results may appear to be isolated and much different than the rest of the population. If the physical reason for the odd results is known, these data may be (Rethati 1983):

a. Discarded.

b. Discarded and replaced.

c. Corrected on a physical basis.

Corrections on a physical basis involve the use of physical laws or known physical relationships to correct sampling and testing errors. 


\begin{tabular}{||l|l|l|l||}
\hline \multicolumn{2}{||}{$\begin{array}{l}\text { Table 3-3 } \\
\text { Transformation of Allowable Passes Data for an Airfield Feature }\end{array}$} \\
\hline \hline \multicolumn{2}{|c|}{ Allowable Passes } & \multicolumn{2}{c||}{ Log (Allowable Passes) } \\
\hline \hline Class Intervals & Observations & Class Intervals & Observations \\
\hline \hline $181000-200000$ & 3 & $5.26-5.28$ & 1 \\
\hline $201000-220000$ & 2 & $5.29-5.31$ & 2 \\
\hline $221000-240000$ & 5 & $5.32-5.34$ & 2 \\
\hline $241000-260000$ & 6 & $5.35-5.37$ & 4 \\
\hline $261000-280000$ & 9 & $5.38-5.40$ & 5 \\
\hline $281000-300000$ & 14 & $5.41-5.43$ & 7 \\
\hline $301000-320000$ & 16 & $5.44-5.46$ & 12 \\
\hline $321000-340000$ & 21 & $5.47-5.49$ & 16 \\
\hline $341000-360000$ & 10 & $5.50-5.52$ & 21 \\
\hline $361000-380000$ & 11 & $5.53-5.55$ & 16 \\
\hline $381000-400000$ & 5 & $5.56-5.58$ & 11 \\
\hline $401000-420000$ & 5 & $5.59-6.61$ & 8 \\
\hline $421000-440000$ & 4 & $5.62-6.64$ & 6 \\
\hline $441000-460000$ & 2 & $5.65-5.67$ & 3 \\
\hline $461000-480000$ & 2 & $5.68-5.70$ & 3 \\
\hline $481000-500000$ & 1 & $5.71-5.73$ & 1 \\
\hline $501000-520000$ & 1 & $5.74-5.76$ & \\
\hline $521000-540000$ & 1 & & \\
\hline $541000-560000$ & 1 & & 2 \\
\hline
\end{tabular}

Example. Suppose a concrete ready-mix plant performs quality control testing with $152 \times 305-\mathrm{mm}$ cylinders. Suppose further that a few data points in a month's production appear to be outliers (or extreme values), well above the mean. The concrete supplier may discover that these data were obtained with $76 \times 152-m m$ cylinders. The supplier may choose to factor down the strength measurements with known relationships between the strengths measured by the two cylinder sizes. Whether discarding or correcting, all activities should be documented.

If the physical reason for outliers is not known, the outliers may only be removed from the data set with proper statistical procedures. Even with these tools, data removal should be performed sparingly and should be documented. Removing data can be counterproductive if the true dispersion or shape of a distribution is lost. If the apparent outliers are actually 


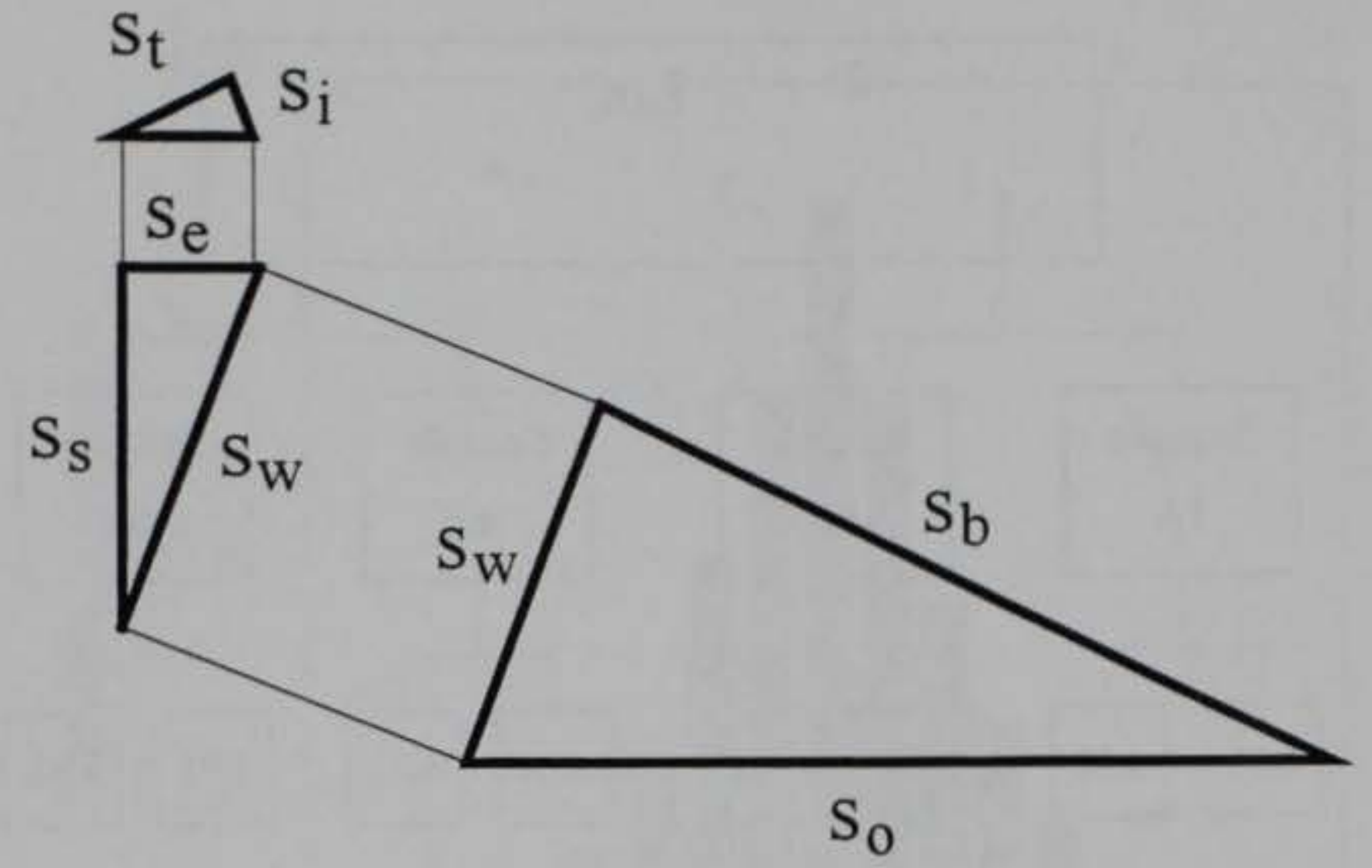

Component Standard Deviations

$$
\begin{aligned}
& \mathrm{S}_{\mathrm{o}}=\text { overall } \\
& \mathrm{S}_{\mathrm{b}}=\text { between-batch } \\
& \mathrm{S}_{\mathrm{w}}=\text { within-batch } \\
& \mathrm{S}_{\mathrm{S}}=\text { sampling } \\
& \mathrm{S}_{\mathrm{e}}=\text { experimental } \\
& \mathrm{S}_{\mathrm{t}}=\text { testing } \\
& \mathrm{S}_{\mathrm{i}}=\text { inherent }
\end{aligned}
$$

reflections of a data set's skewness, then the removal of the outliers would provide a false image of symmetry.

When considering removal of outliers by statistical methods, all possible physical reasons for the outlying data should be investigated. The sampling procedure should be reviewed to ensure that the outlying data came from the same population as the other data. Test procedures should be reviewed to ensure that the outlying data was tested in the same manner as the rest of the observations. Finally, data analyses should be reviewed to ensure that there were no calculation errors. Once these efforts have been exhausted, the next 
referenced

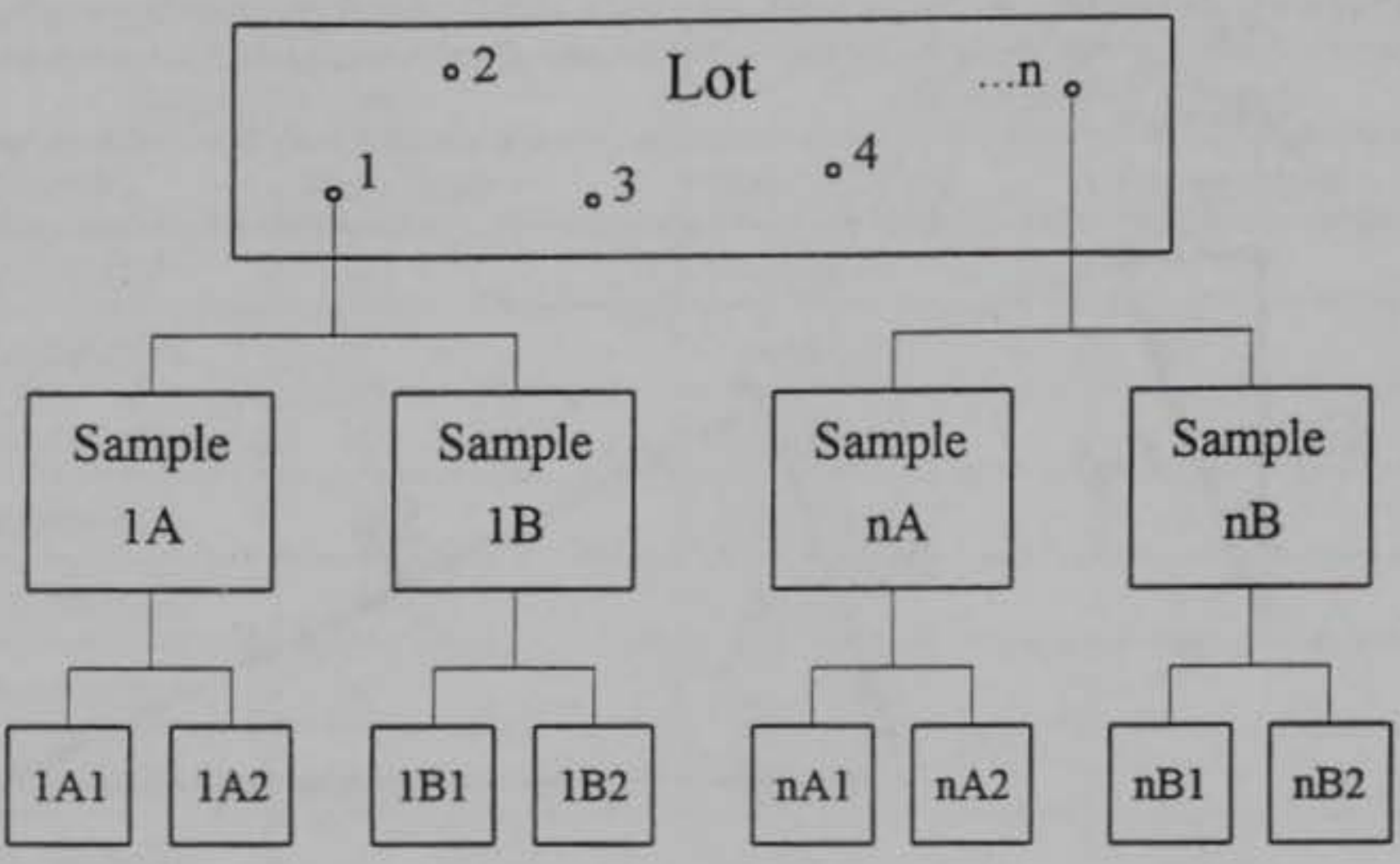

by text on

pg. 60

Figure 3-5. Sampling plan for studying construction site variability

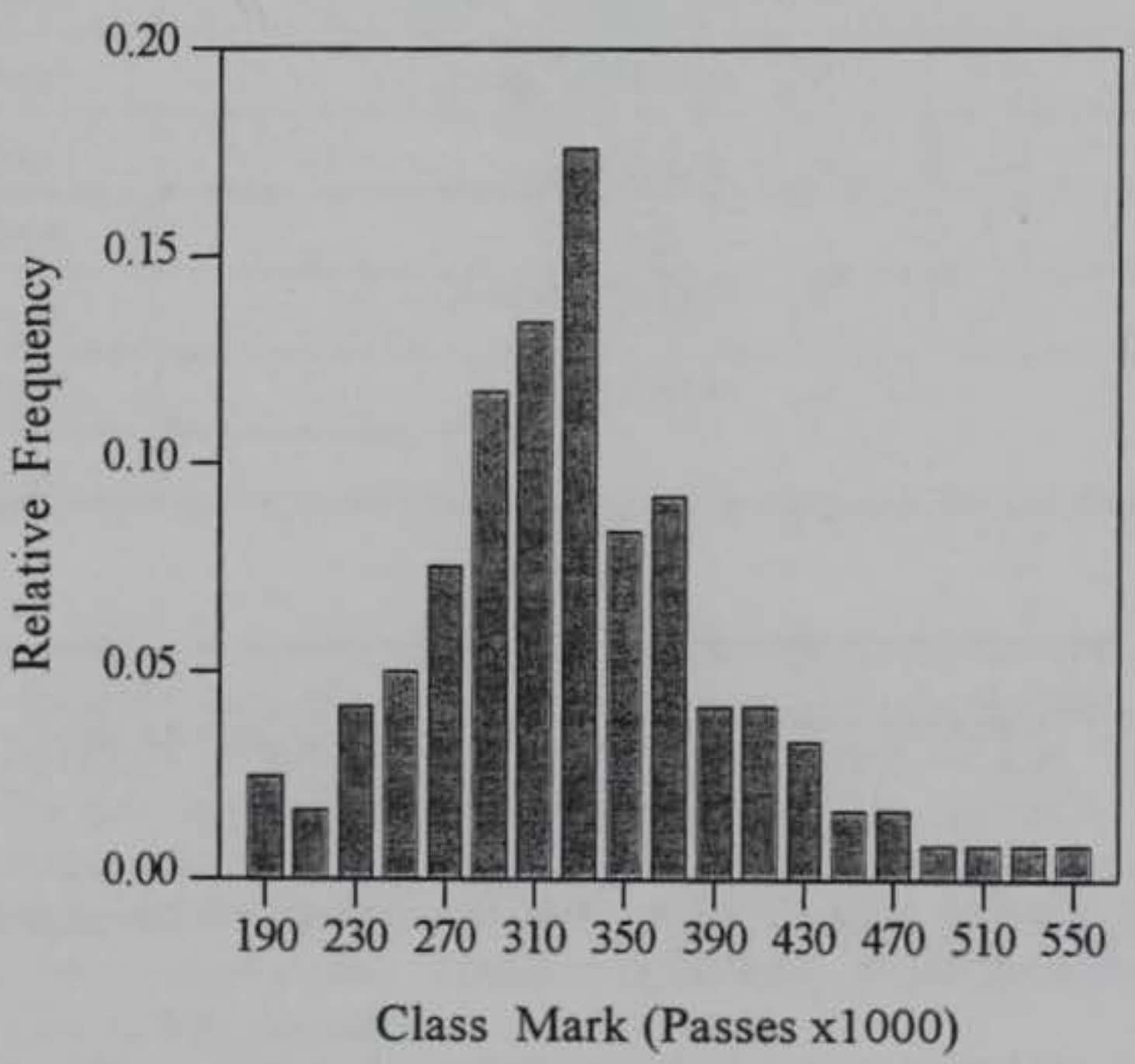

Figure 3-6. Frequency distribution for allowable aircraft passes 


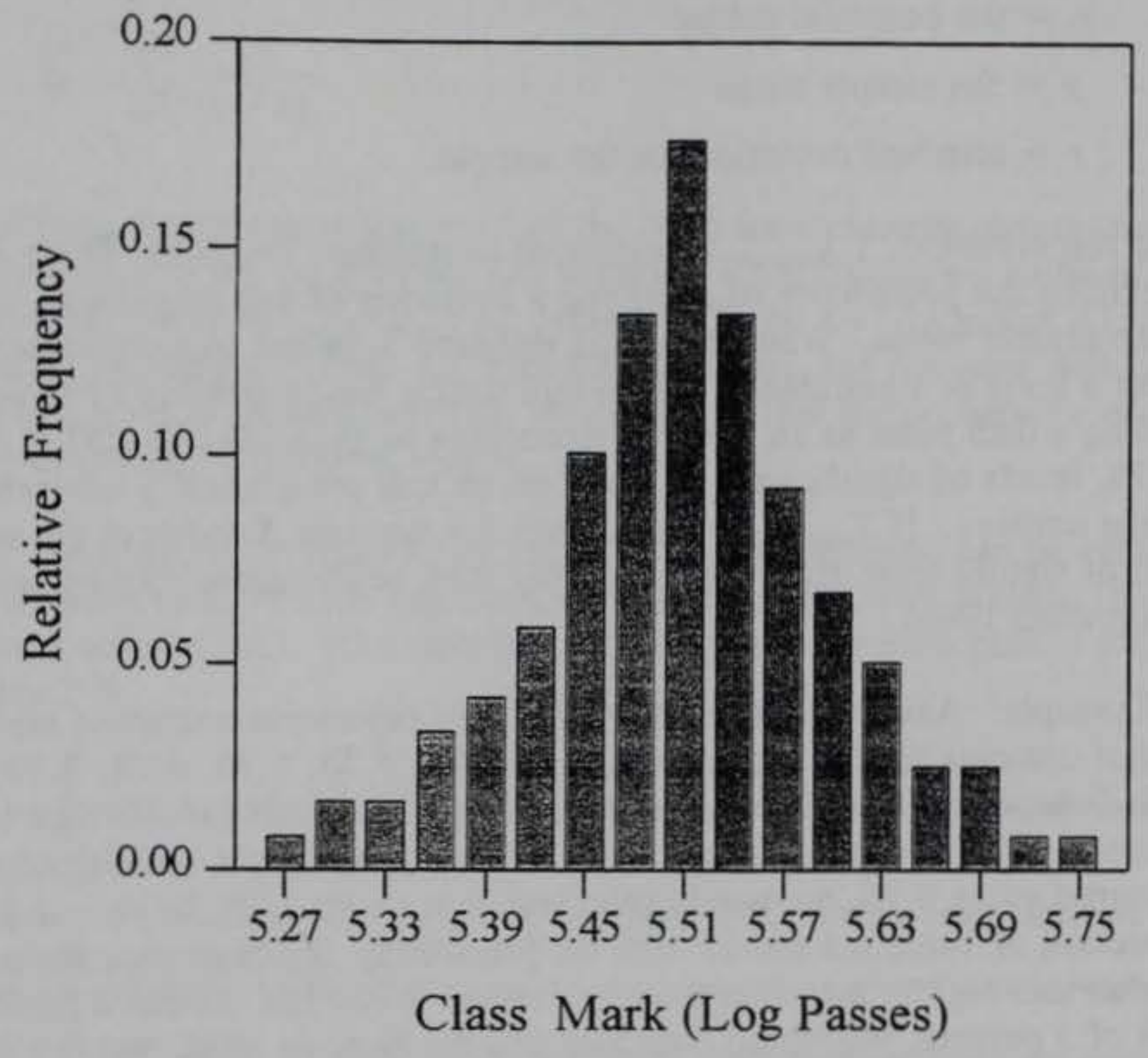

Figure 3-7. Frequency distribution for transformed (log) allowable passes

step is to determine whether the distribution is normal or other shape. The shape of a distribution can influence the choices for oulier testing. Published methods for determining outliers include the T-statistic, the Tietjen-Moore statistic, and Chauvenot's criterion. The T-statistic, which is calculated differently than Student's t-statistic discussed in Chapter 2, can only be applied to normal populations and can only handle a single outlier. The TietjenMoore statistic can also only be applied to normal populations, but it can test for multiple low and high outliers. Chauvenot's criterion can detect multiple outliers and it can be applied to distributions that are other than normal.

The T-statistic, for use with a single outlier, requires conversion of the potential outlier to a test criterion $\left(\mathrm{T}_{\text {calculated }}\right)$ :

$$
T_{\text {calculated }}=\frac{\left|y_{i}-\bar{y}\right|}{s}
$$


where

$$
\begin{aligned}
y_{i} & =\text { the potential outlier } \\
\bar{y} & =\text { the sample mean } \\
s & =\text { standard deviation for the sample. }
\end{aligned}
$$

This test criterion, $\mathrm{T}_{\text {calculated }}$, is compared to standard $\mathrm{T}$-values (Table A5) to determine the probability of obtaining a deviation of this magnitude, relative to the sample mean. When using the standard T-values, the engineer would select a level of significance, which will define the probability of falsely discarding a data point as an outlier. According to guidelines in ASTM (1995b) E 178, levels of significance of 5 percent or less are generally advisable for testing outliers. If $\mathrm{T}_{\text {calculated }}$ is larger than the standard $\mathrm{T}$-value at the selected level of significance, the potential outlier may be discarded (Schiff and D'Agostino 1996).

Example. Assume that the following data represents extracted asphalt cement contents from a single lot: $5.68,5.70,5.70,5.70,5.72,5.72,5.72$, $5.78,5.84$, and 5.96. The mean and standard deviation for this data is 5.75 percent and 0.09 percent, respectively. If we question the validity of the measured value 5.96, we would calculate $\mathrm{T}$ as $(5.96-5.75) / 0.09=2.33$. Inspection of Table A5 reveals that the probability of occurrence for a $\mathrm{T}$-value this high is approximately 2 percent. If we had chosen a significance level of 5 percent, we would conclude that the extreme value did not come from the same population as the rest of the data and it would be discarded.

The Tietjen-Moore (T-M) statistic can be applied in cases where multiple outliers exist on either the low side of the data, the high side of the data, or on both sides of the data (Tietjen and Moore 1972). Let the sample values be $y_{1}, y_{2}, y_{3}, \ldots, y_{n}$ and compute the sample mean, $\bar{y}$. Then compute the $n$ absolute residuals:

$$
r_{1}=\left|y_{1}-\bar{y}\right|, r_{2}=\left|y_{2}-\bar{y}\right|, \ldots, r_{n}=\left|y_{n}-\bar{y}\right|
$$

Now relabel the original observations, $y_{1}, y_{2}, y_{3}, \ldots, y_{n}$, as $z$ 's in such a manner that $z_{i}$ is that observation whose absolute residual is the $i^{\text {th }}$ largest. Relabeled observation $z_{1}$ should have the smallest residual and relabeled observation $z_{n}$ should have the largest residual. The Tietjen-Moore statistic for testing the significance of the $k$ largest residuals is then:

$$
E_{k}=\frac{\sum_{i=1}^{n-k}\left(z_{i}-\overline{z_{k}}\right)^{2}}{\sum_{i=1}^{n}\left(z_{i}-\bar{z}\right)^{2}}
$$


where

$$
\overline{z_{k}}=\sum_{i=1}^{n-k} \frac{z_{i}}{(n-k)}
$$

The term $z_{k}$ represents the mean of the $(n-k)$ least extreme observations and the term $z$ is the mean of the full sample. If the calculated value of $E_{k}$ is smaller than the critical value of $E_{k}$, shown in Table A6 (Appendix A), then the outlier can be discarded. As with the T-statistic, the engineer will have to select a level of significance $(\alpha)$, which will define the probability of falsely discarding a potential outlier.

For the example data shown in Table 3-4, a T-M statistic can be calculated for each of three different cases: one outlier $\left(E_{l}\right)$, two outliers $\left(E_{2}\right)$, and three outliers $\left(E_{3}\right)$. The calculated T-M statistic for each case is shown in Table 3-5.

\begin{tabular}{|c|c|c|}
\hline \multicolumn{3}{|c|}{$\begin{array}{l}\text { Table 3-4 } \\
\text { Percent of Particles Finer Than the No. } 200 \text { Sieve for Asphalt } \\
\text { Concrete Aggregate }\end{array}$} \\
\hline Observation (Percent) & Absolute Residual $\left(r_{1}\right)$ & $\left(z_{1}-\bar{z}\right)^{2}$ \\
\hline 6.1 & 0.21 & 0.0441 \\
\hline 6.0 & 0.11 & 0.0121 \\
\hline 5.8 & 0.09 & 0.0081 \\
\hline 5.7 & 0.19 & 0.0361 \\
\hline 5.9 & 0.01 & 0.0001 \\
\hline 5.5 & 0.39 & 0.1521 \\
\hline 5.4 & 0.49 & 0.2401 \\
\hline 5.6 & 0.29 & 0.0841 \\
\hline 6.0 & 0.11 & 0.0121 \\
\hline 6.9 & 1.01 & 1.0201 \\
\hline
\end{tabular}

The critical T-M statistics for this problem can be obtained from Table A6. Assuming that the chosen level of significance is 5 percent, the $\mathrm{T}-\mathrm{M}$ statistic for 10 observations for one, two, and three outliers is 0.353 , 0.172 , and 0.083 , respectively. An observation can be considered an outlier if the calculated T-M statistic is less than the critical T-M statistic. Therefore, the data set has only one outlier. This outlier would be the observation with the largest absolute residual, which is 6.9 percent. 


\begin{tabular}{|c|c|c|}
\hline \multicolumn{3}{|c|}{$\begin{array}{l}\text { Table 3-5 } \\
\text { Execution of the Tietjen-Moore Statistic for Determining of } \\
\text { Outliers }\end{array}$} \\
\hline Number of Outliers & $z_{k}$ & $E_{k}$ \\
\hline 1 & 5.778 & $0.476 / 1.609=0.296$ \\
\hline 2 & 5.825 & $0.315 / 1.609=0.196$ \\
\hline 3 & 5.871 & $0.194 / 1.609=0.121$ \\
\hline
\end{tabular}

Chauvenot's criterion was originally developed for applications related to the standard normal distribution (Coleman and Steel 1989). However, as described below, it can be applied to any known or assumed probability density function. The criterion permits rejection of all points that fall outside of a designated band around the sample mean. The width of the band corresponds to an area under the probability density function equal to $1-(1 /(2 n))$ percent, where $\mathrm{n}$ equals the number of measurements in the data set. For sample sizes ranging from 5 to 50 , the area for the acceptance region ranges from 0.90 to 0.99 , corresponding to areas for rejection regions from 0.10 to 0.01 , respectively, as shown in Table 3-6. Chauvenot's criterion is always treated as a two-tailed significance test: one-half of the rejection region lies at the upper end of the probability density function and one-half of the rejection region lies at the lower end of the probability density function.

If the distribution of data is assumed to be normal, potential outliers can be compared to the rejection band limits by converting their measured values to a Chauvenot Criterion as follows:

$$
\tau_{\text {calculated }}=\frac{\left|y_{i}-\bar{y}\right|}{s}
$$

where

$$
\begin{aligned}
& y_{i}=\text { the potential outlier } \\
& \bar{y}=\text { the sample mean } \\
& s=\text { standard deviation for the sample }
\end{aligned}
$$

This conversion is the same as that used for the T-statistic. The values for $\tau_{\text {calculared }}$ can then be compared to values for $\tau_{\text {rejection, }}$, which represent the boundaries of the two-tail rejection region shown in Table 3-6. Maintaining the assumption of normality, the values for $\tau_{\text {rejection }}$ can be obtained from any standard normal table, such as that shown in Table A1. Each value for $\tau_{\text {rejection }}$ is obtained using the appropriate two-tailed rejection region.

Using the 10 observations from the T-statistic example, determination of $\tau_{\text {rejection }}$ would require the use of 0.025 as the two-tailed rejection region, as 


\begin{tabular}{|c|c|c|c|}
\hline \multicolumn{4}{|c|}{$\begin{array}{l}\text { Table 3-6 } \\
\text { Chauvenot's Criteria for Determination of Outliers (Coleman ano } \\
\text { Steele 1989) }\end{array}$} \\
\hline $\begin{array}{l}\text { Number of } \\
\text { Samples } \\
\end{array}$ & $\begin{array}{l}\text { Area of } \\
\text { Acceptance }\end{array}$ & $\begin{array}{l}\text { Total Area of } \\
\text { Rejection }\end{array}$ & $\begin{array}{l}\text { One-Half Rejection } \\
\text { Area' }\end{array}$ \\
\hline 5 & 0.90 & 0.100 & 0.050 \\
\hline 10 & 0.95 & 0.050 & 0.025 \\
\hline 20 & 0.975 & 0.025 & 0.0125 \\
\hline 50 & 0.99 & 0.010 & 0.005 \\
\hline
\end{tabular}

defined in Table 3-6. From Table A1, $\tau_{\text {rejection }}$ is found to equal 1.96. The value of $\tau_{\text {calculated }}$ for the highest measured asphalt cement content of 5.96 would be 2.33 , which is greater than $\tau_{\text {rejection. }}$. This measurement happens to be the only data point with $\tau_{\text {calculared }}$ greater than $\tau_{\text {rejection }}$. Similar to the T-statistic conclusion, Chauvenot's criterion indicates that 5.96 should be discarded as an outlier.

Using the data from the Tietjen-Moore (T-M) example, which also included 10 observations, $\tau_{\text {rejection }}$ would be defined similar to the T-statistic example (1.96). Using the sample standard deviation of 0.42 percent, the lowest and highest measurements for percent passing would transform to $\tau_{\text {calculared }}$ values of 1.17 and 2.40 , respectively. The highest measurement (6.9 percent) has a $\tau_{\text {calculated }}$ value larger than the $\tau_{\text {rejection }}$ of 1.96 . This measurement happens to be the only data point with $\tau_{\text {calculared }}$ greater than $\tau_{\text {rejection }}$. Therefore, similar to the T-M statistic conclusion, Chauvenot's criterion indicates that the measurement of 6.9 percent passing the No. 200 sieve should be discarded as an outlier.

If the distribution is known to conform to a beta shape, rather than normal, the concept of Chauvenot's criterion can still be applied. However, instead of comparing the data to a standard normal distribution, the data is compared to a theoretical beta distribution. The area of the acceptance region can still be calculated as $1-1 /(2 n)$ percent and the area of the rejection region as $1 /(2 n)$ percent. The rejection region can still be considered twotailed. The band limits on the distribution, to be used for rejection criteria, can then be determined using Harr's program BETA (Harr 1987). The user of BETA only needs to know the distribution's minimum value, maximum value, mean, and coefficient of variation. If the rejection area has been determined to be 0.10 , then the upper band limit corresponds to the value that has only a 5 percent chance of being exceeded by randomly selected values. The lower band limit corresponds to the value that has a 95 percent chance of being exceeded by randomly selected values.

Regardless of the distribution shape or the method of testing for outliers, the test should only be performed one time for a set of data. In other words, 
once one or more points have been rejected, the tests for outliers should not be repeated on the new, smaller data set. Repeated application of outlier tests on the same data set would result in an erroneous overall significance level $(\alpha)$.

\section{Components of Variability}

When studying the variability of materials, there are two types of analyses that are of primary interest to the construction industry. The first type of analysis is intended to study the variability of a test method or process specifically. In this case, the material to be subjected to the test is collected and homogenized at a single location. Typically, the material is then sent to several laboratories for testing by a single operator from each laboratory. These analyses are often referred to as "round robin" studies because samples from the same homogeneous material are provided to all the parties involved.

The second type of anlysis is intended to differentiate between the variability associated with sampling and testing a heterogeneous material obtained from a construction site, rock quarry, asphalt plant, etc. In order to keep the components of variability reasonable in this type of analysis, a single laboratory should be involved in the testing. These analyses are often referred to as "construction site" studies because the results pertain to a particular project and the results are useful for developing reasonable contract specification criteria.

\section{Round robin studies}

Round robin studies are often used for developing precision statements for test methods. In accordance with ASTM (1995a) C 670, two basic elements of precision are needed: single-operator precision and multilaboratory precision. Single operator precision provides an estimate of the difference that may be expected between duplicate measurements made on the same material in the same laboratory by the same operator using the same apparatus within a time span of a few days [ASTM (1995a) C 802]. This within-laboratory precision is often referred to as the repeatability of the test. Multilaboratory precision provides an estimate of the difference that may be expected between measurements made on the same material in two different laboratories [ASTM (1995a) C 802]. This between-laboratory precision is often referred to as the reproducibility of the test method.

At least ten different laboratories should be included in a round robin study [ASTM (1995a) C 802]. The number of different types of a material that should be included in this type of study depend on many factors, such as the range of material types to which the test method should apply, the expense of distributing multiple samples, and the test duration. In general, a minimum of three materials should be included [ASTM (1995a) C 802]. The number of replicates necessary for each test on each material is a function of 
the number of laboratories involved. If 15 laboratories are participating, then three replicates is adequate. If less than 15 laboratories are involved, the number of replicates should be increased according to: $(30 / p)+1$ where $\mathrm{p}=$ the number of laboratories. If more than 15 laboratories are involved, the number of replicates can be reduced to two [ASTM (1995a) C 802].

Example. Assume we are interested in the repeatability and reproducibility associated with determining plasticity index (PI) for soil. The fabricated data for this study, which included 15 laboratories, 3 types of soil, and 3 test replicates, are shown in Table 3-7. Within-laboratory averages and within-laboratory variances are shown in Table 3-8. The overall mean and the pooled variance for PI for each soil type are also shown in Table 3-8.

\begin{tabular}{|c|c|c|c|c|c|c|c|c|c|}
\hline \multicolumn{10}{|c|}{$\begin{array}{l}\text { Table 3-7 } \\
\text { Raw Data for a Fabricated Round Robin Experiment Concerning } \\
\text { Plasticity Index of Soils }\end{array}$} \\
\hline \multirow{2}{*}{$\begin{array}{c}\text { Laboratory } \\
1 \\
\end{array}$} & \multicolumn{3}{|c|}{ High-Plasticity Soil } & \multicolumn{3}{|c|}{ Medium-Plasticity Soil } & \multicolumn{3}{|c|}{ Low-Plasticity Soil } \\
\hline & 30 & 31 & 30 & 13 & 11 & 11 & 4 & 3 & 3 \\
\hline 2 & 32 & 31 & 30 & 10 & 11 & 12 & 8 & 5 & 7 \\
\hline 3 & 35 & 35 & 34 & 14 & 13 & 14 & 5 & 6 & 5 \\
\hline 4 & 30 & 30 & 31 & 7 & 6 & 5 & 2 & 4 & 2 \\
\hline 5 & 36 & 35 & 37 & 11 & 12 & 10 & 5 & 3 & 4 \\
\hline 6 & 36 & 35 & 36 & 10 & 11 & 11 & 1 & 2 & 3 \\
\hline 7 & 35 & 36 & 37 & 13 & 11 & 12 & 1 & 2 & 2 \\
\hline 8 & 31 & 32 & 32 & 12 & 13 & 14 & 6 & 5 & 7 \\
\hline 9 & 36 & 37 & 38 & 11 & 10 & 11 & 8 & 7 & 6 \\
\hline 10 & 31 & 30 & 30 & 8 & 8 & 9 & 4 & 5 & 4 \\
\hline 11 & 31 & 30 & 32 & 11 & 10 & 12 & 5 & 7 & 8 \\
\hline 12 & 31 & 32 & 32 & 12 & 14 & 13 & 5 & 6 & 7 \\
\hline 13 & 30 & 31 & 30 & 7 & 6 & 5 & 2 & 4 & 2 \\
\hline 14 & 32 & 33 & 33 & 11 & 13 & 11 & 3 & 4 & 3 \\
\hline 15 & 35 & 36 & 36 & 11 & 10 & 11 & 2 & 1 & 3 \\
\hline $\begin{array}{l}\text { Overall } \\
\text { variance }\end{array}$ & \multicolumn{3}{|c|}{6.6} & \multicolumn{3}{|c|}{5.5} & \multicolumn{3}{|c|}{4.1} \\
\hline
\end{tabular}

Before proceeding with a statistical analysis of the round robin data, we need to verify two assumptions: homogeneity of within-laboratory variances and absence of substantial interactions between laboratory and soil type. If a single laboratory has an erratic variance compared to the others, it may be eliminated. If all the variances are erratic, however, there is a problem with the test method. Substantial interactions between laboratories and materials 


\begin{tabular}{|c|c|c|c|c|c|c|}
\hline \multicolumn{7}{|c|}{$\begin{array}{l}\text { Table } 3-8 \\
\text { Summary of Mean and Within-Laboratory Variance }\end{array}$} \\
\hline \multirow[b]{2}{*}{ Laboratory } & \multicolumn{2}{|c|}{ High-Plasticity Soil } & \multicolumn{2}{|c|}{ Medium-Plasticity Soil } & \multicolumn{2}{|c|}{ Low-Plasticity Soil } \\
\hline & Mean & Variance & Mean & Variance & Mean & Variance \\
\hline 1 & 30.3 & 0.33 & 11.7 & 1.33 & 3.3 & 0.33 \\
\hline$\underline{2}$ & 31.0 & 1.00 & 11.0 & 1.00 & 6.7 & 2.33 \\
\hline 3 & 34.7 & 0.33 & 13.7 & 0.33 & 5.3 & 0.33 \\
\hline 4 & 30.3 & 0.33 & 6.0 & 1.00 & 2.7 & 1.33 \\
\hline 5 & 36.0 & 1.00 & 11.0 & 1.00 & 4.0 & 1.00 \\
\hline 6 & 35.7 & 0.33 & 10.7 & 0.33 & 2.0 & 1.00 \\
\hline 7 & 36.0 & 1.00 & 12.0 & 1.00 & 1.7 & 0.33 \\
\hline 8 & 31.7 & 0.33 & 13.0 & 1.00 & 6.0 & 1.00 \\
\hline 9 & 37.0 & 1.00 & 10.7 & 0.33 & 7.0 & 1.00 \\
\hline 10 & 30.3 & 0.33 & 8.3 & 0.33 & 4.3 & 0.33 \\
\hline 11 & 31.0 & 1.00 & 11.0 & 1.00 & 6.7 & 2.33 \\
\hline 12 & 31.7 & 0.33 & 13.0 & 1.00 & 6.0 & 1.00 \\
\hline 13 & 30.3 & 0.33 & 6.0 & 1.00 & 2.7 & 1.33 \\
\hline 14 & 32.7 & 0.33 & 11.7 & 1.33 & 3.3 & 0.33 \\
\hline 15 & 35.7 & 0.33 & 10.7 & 0.33 & 2.0 & 1.00 \\
\hline Pooled ${ }^{1.2}$ & 33.0 & 0.55 & 10.7 & 0.82 & 4.2 & 1.00 \\
\hline
\end{tabular}

would also indicate either a problem with a laboratory or a problem with the test method. In an extreme case of interaction, the laboratories may not report the same ranking of materials, in terms of the magnitude of test results.

Homogeneity of variances for each material may be tested with the Hartley F-max test (Freund and Wilson 1993). This method simply involves finding the largest ratio of within-laboratory variances and then comparing this ratio to the F-max distribution data shown in Table A7 (Appendix A). The null hypothesis for this test states that the variances are homogeneous. The alternative hypothesis states that at least two variances are not equal. If the calculated ratio is larger than the critical value shown in Table A7, then the null hypothesis would be rejected. The largest ratio of variances found within high-plasticity soil, medium-plasticity soil, and low-plasticity soil was $3.0(1.0 / 0.33), 4.0(1.33 / 0.33)$, and $7.0(2.33 / 0.33)$, respectively. For 15 laboratories, 3 replicates per laboratory, and a level of significance of 5 percent, the critical F-max value is 855 . The critical F-max value is high 
because our estimates for within-laboratory variability are poor (only 3 replicates). We have no reason to reject the null hypothesis of equal variances.

Substantial interactions can be checked by inspecting the reported means for plasticity index in Table 3-8. If we ranked the reported means from each laboratory, we would find that each laboratory reported the lowest PI for the same material and the highest PI for the same material. There does not seem to be any laboratory that reported a different trend in results, relative to the other laboratories. We can state that there are no substantial interactions.

Having verified the assumptions of homogeneous variances and the absence of substantial interaction, a statistical computer program such as SigmaStat ${ }^{*}$ or SAS $^{*}$ can be used to perform an analysis of variance (ANOVA) procedure for each soil type. This permits estimation of the betweenlaboratory variances and verification of the pooled within-laboratory variances. Since the number of replicates was the same for each laboratory, the pooled within-laboratory variance in this case is calculated as a simple average. The analysis is similar to a completely randomized experimental design where laboratories are the treatment factors and the variation within laboratories reflects experimental error and sampling error. Summary ANOVA output tables are shown in Tables 3-9 through 3-11.

\begin{tabular}{|c|c|c|c|c|}
\hline \multicolumn{5}{|c|}{$\begin{array}{l}\text { Table } 3-9 \\
\text { Round Robin Analysis of Variance for Plasticity Index Using High } \\
\text { Plasticity Soil }\end{array}$} \\
\hline Source of Variability & $\begin{array}{l}\text { Degrees of } \\
\text { Freedom }\end{array}$ & $\begin{array}{l}\text { Sum of } \\
\text { Squares }\end{array}$ & $\begin{array}{l}\text { Mean } \\
\text { Square }\end{array}$ & $\begin{array}{l}\text { Expected } \\
\text { Mean Square }\end{array}$ \\
\hline Laboratory & $p-1=14$ & 273.2 & 19.52 & $a_{x}{ }^{2}+r\left(a_{0}{ }^{2}\right)$ \\
\hline Error & $p(r-1)=30$ & 16.7 & 0.55 & $a_{n}^{2}$ \\
\hline Corrected total & $\mathrm{pr}-1=44$ & 289.9 & N/A & N/A \\
\hline
\end{tabular}

The ANOVA tables list two individual sources of variability: error and laboratory. The error component represents within-laboratory variability. The laboratory component includes both within-laboratory variability and between-laboratory variability. The ANOVA results include the calculation of a sum of squares term and a mean square term for each source of variability, as shown. A sum of squares is simply the sum of squared deviations from the mean, as discussed in Chapter 2. A mean square is the sum of squares divided by the degrees of freedom for the particular source of variability. The mean square terms can be compared to the expected mean square formulas, which are known because they comprise the mathematical basis of the ANOVA. Collectively, these comparisons provide two equations and two unknowns (within-laboratory variance and between-laboratory 
variance). After calculating these variances, they can be added to estimate the overall variance. These computed results are summarized in Table 3-12.

\section{Table 3-10 \\ Round Robin Analysis of Variance for Plasticity Index Using Medium-Plasticity Soil}

\begin{tabular}{|c|c|c|c|c|}
\hline Source of Variability & $\begin{array}{l}\text { Degrees of } \\
\text { Freedom }\end{array}$ & Sum of Squares & Mean Square & $\begin{array}{l}\text { Expected } \\
\text { Mean Square }{ }^{2}\end{array}$ \\
\hline Laboratory & $p-1=14$ & 219.0 & 15.64 & $\sigma_{v}{ }^{2}+r\left(\sigma_{0}{ }^{2}\right)$ \\
\hline Error & $p(r-1)=30$ & 24.7 & 0.82 & $\sigma_{v}^{2}$ \\
\hline Corrected total & $p r-1=44$ & 243.6 & N/A & N/A \\
\hline
\end{tabular}

Table 3-11

Round Robin Analysis of Variance for Plasticity Index Using LowPlasticity Soil

\begin{tabular}{|c|c|c|c|c|}
\hline Source of Variability & $\begin{array}{l}\text { Degrees of } \\
\text { Freedom }{ }^{1}\end{array}$ & $\begin{array}{l}\text { Sum of } \\
\text { Squares }\end{array}$ & Mean Square & $\begin{array}{l}\text { Expected Mean } \\
\text { Square }^{2}\end{array}$ \\
\hline Laboratory & $p-1=14$ & 150.3 & 10.74 & $\sigma_{w}^{2}+r\left(\sigma_{p}^{2}\right)$ \\
\hline Error & $p(r-1)=30$ & 30.0 & 1.00 & $\sigma_{x}{ }^{2}$ \\
\hline Corrected total & $p r-1=44$ & 180.3 & & \\
\hline
\end{tabular}

Table 3-12

Summary of Round Robin PI Data by Soil Type

\begin{tabular}{||l|c|l|l|l||}
\hline \multirow{2}{*}{ Soil Type } & \multirow{2}{*}{$\begin{array}{l}\text { Mean, } \\
\text { Percent }\end{array}$} & $\begin{array}{l}\text { Within- } \\
\text { Laboratory }\end{array}$ & Between-Laboratory & $\begin{array}{l}\text { Overall } \\
\text { Variance' }\end{array}$ \\
\cline { 3 - 6 } & 4.2 & 1.00 & 3.25 & 4.25 \\
\hline \hline Low-plasticity & 10.7 & 0.82 & 4.94 & 5.76 \\
\hline Medium-plasticity & 33.0 & 0.55 & 6.32 & 6.87 \\
\hline High-plasticity & Overall variance $=$ within-laboratory variance + between-laboratory variance. \\
\hline \hline
\end{tabular}


A comparison between Tables 3-8 and 3-12 reveals that the ANOVAderived within-laboratory variances match the hand-calculated pooled variances exactly. Inspection of Table 3-12 also reveals that the betweenlaboratory variances were approximately three to eleven times larger than the within-laboratory variances. The estimated variances and the calculated means can be used to calculate standard deviations and coefficients of variation, as shown in Table 3-13. The soil types have been organized in the table in order of increasing mean to permit a search for trends in standard deviation and coefficient of variation. These trends will determine the most appropriate form for the precision statements.

Table 3-13

Standard Deviations and Coefficients of Variation for PI Data

\begin{tabular}{|c|c|c|c|c|c|}
\hline \multirow[b]{2}{*}{ Soil Type } & \multirow[b]{2}{*}{$\begin{array}{l}\text { Mean, } \\
\text { Percent }\end{array}$} & \multicolumn{2}{|c|}{$\begin{array}{c}\text { Standard Deviation, } \\
\text { Percent }\end{array}$} & \multicolumn{2}{|c|}{$\begin{array}{c}\text { Coefficient of Variation, } \\
\text { Percent }\end{array}$} \\
\hline & & $\begin{array}{l}\text { Within- } \\
\text { Laboratory }\end{array}$ & $\begin{array}{l}\text { Between- } \\
\text { Laboratory }\end{array}$ & $\begin{array}{l}\text { Within- } \\
\text { Laboratory }\end{array}$ & $\begin{array}{l}\text { Between- } \\
\text { Laboratory }\end{array}$ \\
\hline Low-plasticity & 4.2 & 1.00 & 1.80 & 24 & 43 \\
\hline Medium-plasticity & 10.7 & 0.91 & 2.22 & 8.5 & 21 \\
\hline High-plasticity & 33.0 & 0.74 & 2.51 & 2.2 & 7.6 \\
\hline
\end{tabular}

The form of precision statements will depend on the relationship between standard deviation (within-laboratory and between-laboratory) and mean material property. Generally, this relationship will fall into one of two categories: either the standard deviation remains approximately constant over the range of mean values or the coefficient of variation remains approximately constant over the range of mean values. In the case of constant standard deviation, the coefficient of variation would have to decrease as mean increases. In the case of constant coefficient of variation, the standard deviation would have to increase as mean increases. Inspection of Table 3-13 reveals that for this round robin experiment, standard deviation remained approximately constant across the range of mean PI, for both withinlaboratory and between-laboratory components of variability. The precision statement would therefore be most useful if written in terms of standard deviation, rather than in terms of coefficient of variation.

The precision statement developed from this fabricated round robin experiment is shown in Table 3-14. The standard deviations reported in Table 3-14 were calculated by averaging over the three soil types included in the study. Assuming that the test method specification will require two replicates, the precision statement will include an allowable difference for two measurements, which is calculated by multiplying the standard deviation by 2.8. According to ASTM (1995a) C 670, this difference between two measurements represents that which should be exceeded, on the average, only 5 percent of the time. There are many other forms of precision statements, including those that are based on coefficient of variation. Also, 


\begin{tabular}{|c|c|c|}
\hline \multicolumn{3}{|c|}{$\begin{array}{l}\text { Table 3-14 } \\
\text { Precision Statement for Plasticity Index }\end{array}$} \\
\hline Type Index & Standard Deviation, Percent & $\begin{array}{l}\text { Acceptable Range of Two } \\
\text { Test Results, Percent }\end{array}$ \\
\hline Single-operator & 0.88 & $2.5^{\prime}$ \\
\hline Multilaboratory & 2.18 & $6.1^{2}$ \\
\hline
\end{tabular}

precision statements can be written for specifications that require more than two replicates. Detailed information on developing precision statements is provided in ASTM (1995a) C 670 and ASTM (1995b) E 177.

\section{Construction site studies}

The variabilities of concern for construction site operations typically involve a single testing laboratory. Multiple laboratories would not normally be involved in a single project's quality control or quality assurance. Typically, a contractors' performance and subsequent payment are judged for each "lot" of material separately. A lot can be defined as an isolated quantity of material or process accumulated under conditions that are considered uniform for sampling purposes [ASTM (1995b) E 105, AASHTO (1995) R 10]. Examples of lots include 1,800 metric tons of asphalt concrete, $8 \mathrm{hrs}$ worth of production of asphalt concrete, a single lift of select fill considered to be constructed with a uniform material and under uniform conditions, or a 1,000 -ft section of completed airfield taxiway.

The concepts presented in the following discussion are applicable for sampling and testing all construction materials, but portland cement concrete will be used as the example. A single lot of concrete can consist of many truckloads, each of which can be considered a "batch." The overall variation of concrete in a lot can therefore be broken down into between-batch variation and within-batch variation. Between-batch variation represents the difference in test results from one batch to another for a material that is supposedly produced consistently.

The within-batch variation, which represents the variabilities that exist within any single batch, can be broken down into sampling error and experimental error. Sampling error is caused by some inconsistency in the sampling procedure that disturbs the random selection process. A popular example is sampling aggregate from a segregated stockpile. Experimental error can be further broken down into two components: testing error and inherent variability. Testing errors are caused by inconsistencies that occur while performing the same test on multiple samples. Testing variation is affected by the repeatability of a test, technician skills, the condition of equipment, and the methods used for reducing samples to a size that is 
appropriate for testing (Nicotera 1974). Testing variation can be quantified by repeating the same test on similar samples of material. Inherent variability is governed by the laws of chance and it is unavoidable. Its magnitude will vary depending on the material and the test. For a particular situation, the influence of inherent variability on an analysis of variance (ANOVA) can only be reduced by increasing the number of test replicates (Waller 1966).

Between-batch variation typically exceeds within-batch variation. This relationship is similar to the case where between-laboratory variation typically exceeds within-laboratory variation for round robin experiments (Nicotera 1974).

The components of variance for a construction site material study are additive. The Pythagorean theorem provides a visual tool for relating variance components back to standard deviations (Newlon 1966, Waller 1966). If the length of each orthogonal side of a right triangle is equal to a component standard deviation, the variance associated with the hypotenuse equals the sum of the orthogonal sides squared, as shown in Figure 3-4. Overall variance equals between-batch variance plus within-batch variance. Withinbatch variance equals sampling variance plus variance associated with experi$\left\{\begin{array}{l}\text { figure on } \\ \text { pg. } 43\end{array}\right.$ mental error. Experimental variance is composed of testing variability and inherent material variability, but these components are difficult to separate (Nicotera 1974).

$$
\begin{aligned}
& s_{\text {overall }}^{2}=s_{\text {berween-batch }}^{2}+s_{\text {within-batch }}^{2} \\
& s_{\text {within-batch }}^{2}=s_{\text {sampling }}^{2}+s_{\text {experimental }}^{2}
\end{aligned}
$$

Between-batch variance reflects the "control" of a construction operation, so it is typically the quantity needed for judging contractor performance. If the batch-to-batch variance is large relative to the within-batch variance, the operation can be judged "out of control" (Waller 1966). Accurate determination of material variances is facilitated by two procedures: (1) reducing sampling and testing variabilities through standardization of sampling and testing procedures and (2) increasing the number of test replicates within a sampling plan (Newlon 1966).

Similar to the round robin experiment, different components of variance can be isolated with an anlaysis of variance (ANOVA) procedure. The procedure used for the ANOVA will depend on the number and nature of the different sources of variation.

Example. Brown (1966) used an analysis of variance procedure to isolate sources of variation for the compressive strengths of steam cured concrete. $\mathrm{He}$ was concerned with the relative proportions of variation that existed between concrete batches and within concrete batches: $\sigma_{\text {total }}^{2}=\sigma_{\text {between }}^{2}+$ $\sigma_{\text {within }}^{2}$. A large variation between groups, relative to the variation within 
groups, would indicate the existence of a material control problem. Example data is shown in Table 3-15.

\begin{tabular}{|c|c|c|c|}
\hline \multicolumn{4}{|c|}{$\begin{array}{l}\text { Table 3-15 } \\
\text { Compressive Strengths of Steam-Cured Concrete, MPa (after } \\
\text { Brown 1966) }\end{array}$} \\
\hline Batch No. & Sample No. 1 & Sample No. 2 & Total \\
\hline 1 & 30.3 & 30.1 & 60.4 \\
\hline 2 & 31.2 & 31.4 & 62.6 \\
\hline 3 & 28.1 & 29.0 & 57.1 \\
\hline 4 & 31.7 & 32.3 & 64.0 \\
\hline 5 & 31.2 & 31.7 & 62.9 \\
\hline \multicolumn{3}{|c|}{ Overall total (for $\mathrm{N}=10$ samples) } & 307.0 \\
\hline \multicolumn{3}{|c|}{ Overall average } & 30.7 \\
\hline
\end{tabular}

Due to the few sources of variation and the small dataset, Brown (1966) was able to demonstrate the ANOVA with hand calculations, as shown in Table 3-16. This analysis is similar to a completely randomized experimental design where concrete batches are the treatment factors and variation within batches reflects experimental error and sampling. The between-batch component of variance accounted for a significant proportion (93 percent) of the overall variance.

If this ANOVA had been performed with commercial software, such as SAS $^{*}$, the output would look similar to Table 3-17. Similar to the ANOVA in the round robin experiment, the calculated mean squares can be compared to the expected mean squares to obtain estimates for two sources of variability. In this case, the two sources are within-batch variance and betweenbatch variance. Results from calculations using the ANOVA output are summarized in Table 3-18. Similar to the hand calculations, the betweenbatch variance accounted for 92 percent of the total variance. The large ratio of between-batch variance to within-batch variance indicated to Brown (1966) that he had a concrete production control problem.

Example. In a study with a similar experimental design, Hughes and Anday (1966) used analysis of variance techniques to optimize the efficiency of nuclear density gage quality control testing. In order to optimize efficiency, they needed to differentiate between two components of variance within a typical lot of soil: between-test variability and between-test-site variability. Between-test variability referred to variance between repeated tests performed at the same location. Between-test-site variability referred to variance between the test results at different locations within the same lot. 


\begin{tabular}{|c|c|c|c|}
\hline \multicolumn{4}{|c|}{$\begin{array}{l}\text { Table 3-16 } \\
\text { Example of Computational Procedures for Variance Analysis } \\
\text { (after Brown 1966) }\end{array}$} \\
\hline \multirow[b]{2}{*}{ Computational Steps } & \multicolumn{3}{|c|}{ Sources of Variation } \\
\hline & $\begin{array}{l}\text { Between- } \\
\text { Batches } \\
\end{array}$ & $\begin{array}{l}\text { Within- } \\
\text { Batches } \\
\end{array}$ & Total \\
\hline a. Enter squared values & $\begin{array}{l}60.4^{2}+62.6^{2}+ \\
\ldots+62.9^{2} \\
\end{array}$ & N/A & $\begin{array}{l}30.3^{2}+30.1^{2}+ \\
\ldots+31.7^{2} \\
\end{array}$ \\
\hline b. Sum of "a" & $18,879.7$ & N/A & $9,440.6$ \\
\hline $\begin{array}{l}\text { c. No. of tests per each entry } \\
\text { in "a" }\end{array}$ & 2 & N/A & 1 \\
\hline $\begin{array}{l}\text { d. Crude sum of squares, } \\
\text { "b"/"c" }\end{array}$ & 9439.9 & N/A & 9440.6 \\
\hline $\begin{array}{l}\text { e. Correction factor, } \\
\mathrm{C}=(\text { grand total })^{2} / \mathrm{N}\end{array}$ & 9424.9 & N/A & 9424.9 \\
\hline f. Corrected sum of squares & $\begin{array}{l}\left(d_{1}{ }^{*}-e\right) \\
15.0\end{array}$ & $\begin{array}{l}\left(f_{3}-f_{1}\right) \\
0.7\end{array}$ & $\begin{array}{l}\left(d_{3}-e\right) \\
15.7\end{array}$ \\
\hline 9. Degrees of freedom & $\begin{array}{l}\text { (\# batch }-1 \text { ) } \\
4\end{array}$ & $\frac{\left(g_{3}-g_{1}\right)}{5}$ & $\begin{array}{l}(N-1) \\
9\end{array}$ \\
\hline h. Mean square, $" f " / " g "$ & 3.75 & 0.14 & N/A \\
\hline I. Component of variance & $\begin{array}{l}\left(h_{1}-h_{2}\right) / c_{1} \\
1.81\end{array}$ & $\begin{array}{l}h_{2} \\
0.14 \\
\end{array}$ & $\begin{array}{l}\left(i_{1}+i_{2}\right) \\
1.95\end{array}$ \\
\hline j. Component of variance, $\%$ & 93 & 7 & 100 \\
\hline
\end{tabular}

\begin{tabular}{|c|c|c|c|c|}
\hline \multicolumn{5}{|c|}{$\begin{array}{l}\text { Table 3-17 } \\
\text { Analysis of Variance for Concrete Compressive Strength }\end{array}$} \\
\hline Source of Variability & $\begin{array}{l}\text { Degrees of } \\
\text { Freedom }\end{array}$ & $\begin{array}{l}\text { Sum of } \\
\text { Squares } \\
\end{array}$ & $\begin{array}{l}\text { Mean } \\
\text { Square } \\
\end{array}$ & $\begin{array}{l}\text { Expected Mean } \\
\text { Square }^{2} \\
\end{array}$ \\
\hline Batches & $p-1=4$ & 14.97 & 3.74 & $a_{w}{ }^{2}+r\left(a_{0}{ }^{2}\right)$ \\
\hline Error & $p(r-1)=5$ & 0.75 & 0.15 & $\sigma_{x}^{2}$ \\
\hline Corrected total & $\mathrm{pr}-1=9$ & 15.72 & N/A & N/A \\
\hline
\end{tabular}

They selected five sections of roadway, each with a different type of soil, and they analyzed the variance components for each section separately. Eight sites for testing were selected randomly within each section and two tests (nuclear gage determinations) were performed at each site. The 


\begin{tabular}{|c|c|c|c|}
\hline \multicolumn{4}{|c|}{$\begin{array}{l}\text { Table 3-18 } \\
\text { Summary of ANOVA Calculation Results for Concrete } \\
\text { Compressive Strength }\end{array}$} \\
\hline \multirow[b]{2}{*}{ Soil Type } & \multicolumn{3}{|c|}{ Components of Variance } \\
\hline & Within-Laboratory & $\begin{array}{l}\text { Between- } \\
\text { Laboratory }\end{array}$ & $\begin{array}{l}\text { Overall } \\
\text { Variance' }\end{array}$ \\
\hline Component of variance $\left(\mathrm{MPa}^{2}\right)$ & 0.15 & 1.80 & 1.95 \\
\hline Percent of variance & 8 & 92 & 100 \\
\hline
\end{tabular}

between-test-site variation provided an indication of the variabilities associated with the material and the construction process. The between-test variation provided an indication of the repeatability of the nuclear gage apparatus when used on the same material. Hughes and Anday (1966) found that the variation between tests accounted for a very small proportion of the total variation. The variation between test-site means, however, was statistically significant. They concluded that if sixteen tests were to be performed within a section (or lot), the standard error for section means would be minimized by selecting sixteen different sites and running only one test per site. Statisticians refer to this as maximizing experimental precision (Petersen 1985).

Hughes and Anday (1966) were not concerned with variance caused by sampling procedures because the repeated tests were performed in the same access hole. In the concrete production example, Brown (1966) also did not feel it necessary to differentiate between the components of within-batch variation. In some cases, however, an engineer may want to break down within-batch variation into sampling error and experimental error. These types of analyses become slightly more complex.

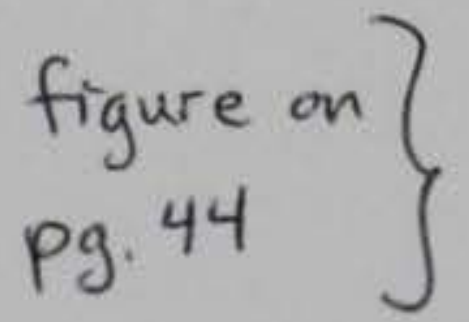

In order to differentiate between sampling variance and experimental variance, one needs a sampling plan such as that shown in Figure 3-5. Multiple batches are randomly selected from a lot of material and then at least two samples are randomly selected from each batch. Finally, material for at least two individual test replicates are split out of each sample. The number of batches selected from each lot would be decided as part of a construction specification acceptance plan. This decision is based on a number of factors, including predetermined party risks, anticipated material variabilities, and type of payment adjustment scheme. It is important to "split out" the test replicates from the samples. The analysis must be able to assume that the test replicates are similar representations of the same sample.

The ANOVA compares the results of individual test portions to define an experimental (testing and inherent) variation. By mathematically combining the test portions within each sample, the ANOVA can compare samples to estimate the sampling variation. Each set of sample increments is then 
mathematically combined into an average batch value to permit determination of batch-to-batch variation (Nicotera 1974).

Example. Data presented by Nicotera (1974) will be used to demonstrate this type of anlysis of variance. The data in Table 3-19 are values for percent passing the 19-mm sieve for aggregates obtained from asphalt concrete extractions. Two samples (A and B) were obtained from 40 different batches. Each sample had enough material for two extraction/gradation tests.

Hand calculations for this level of ANOVA would be tedious. Results provided by SAS ${ }^{*}$ software, however, are shown in Table 3-20. The experimental design can be considered as a completely randomized treatment design with nested subsampling. The batches are the treatment factors and the samples are nested within batches. The variability within samples represents experimental error. Similar to the previous examples, components of variance can be estimated using the expected mean square formulas and the calculated mean squares shown in Table 3-20. Results for these calculations are shown in Table 3-21. Inspection of the components of variance reveals that variation between batches accounted for 36 percent of the overall variance. Testing and inherent variation accounted for 45 percent of the overall variance, which is a relatively large proportion. Sampling accounted for only 19 percent of the overall variance. At first glance, the high proportion of variance within batches $(45+19=64$ percent) would indicate that the procedure for measuring percent passing the $19-\mathrm{mm}$ sieve was not very consistent. However, upon more thorough study, this high proportion of the variance is attributable to a low overall variance. The overall coefficient of variation for percent passing the $19-\mathrm{mm}$ sieve was only 2.7 percent. The control of coarse aggregates for the production of asphalt concrete appears to be in control. The repeatability of asphalt extraction/gradation tests appears to be favorable.

As a method for checking the ANOVA results, the overall variance can be calculated by spreadsheet and compared with the estimated value shown in Table 3-21. Overall variance is simple to calculate because it includes all the data (160 values), without regard for batch, sample, or test designations. Overall variance in this case was calculated to be 6.08 percent $^{2}$, which agreed with the ANOVA results. 


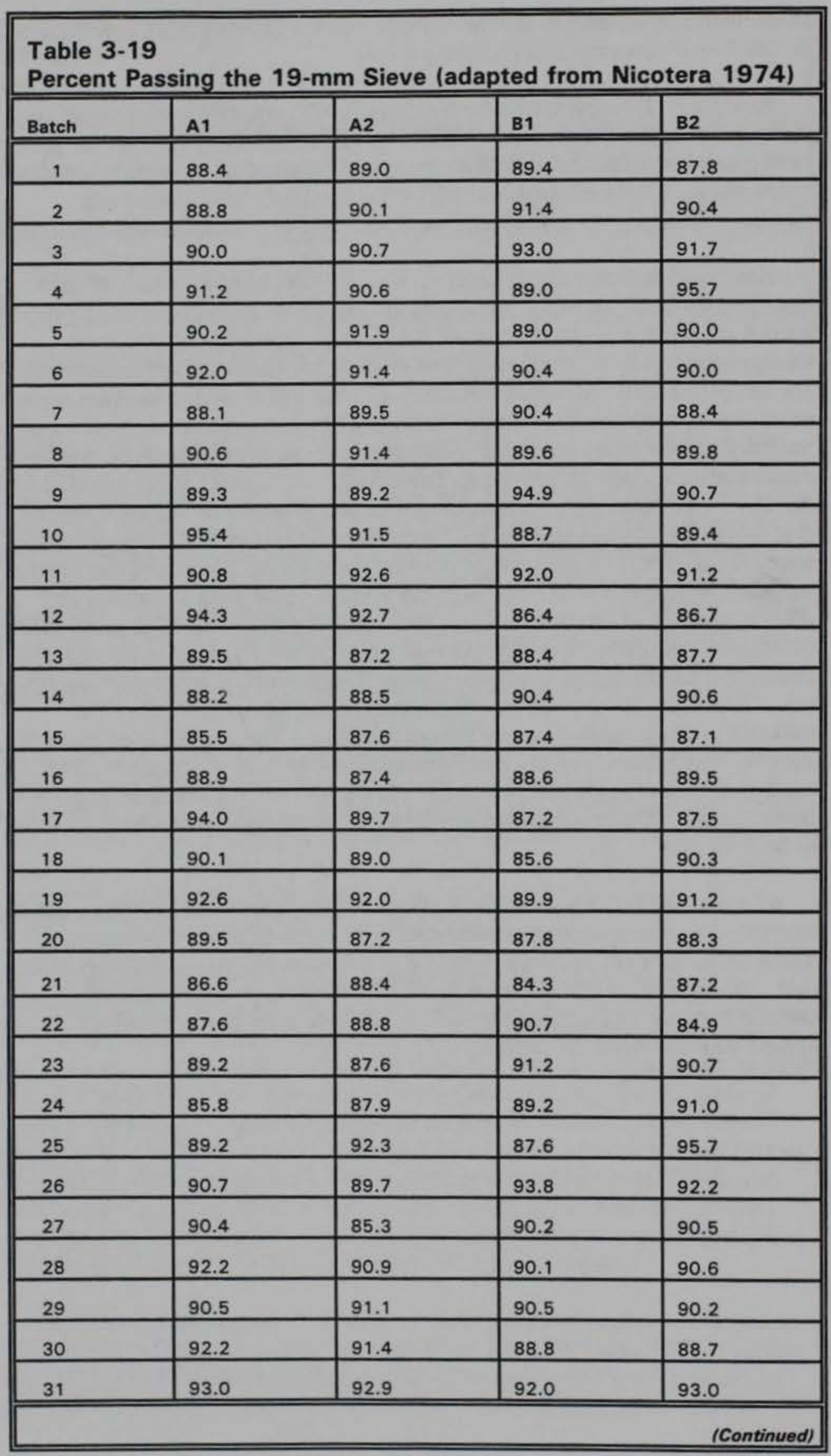




\begin{tabular}{||l|l|l|l|l||}
\hline \hline \multicolumn{5}{||l}{ Table 3-19 (Concluded) } \\
\hline \hline Batch & A1 & A2 & B1 & B2 \\
\hline \hline 32 & 91.0 & 90.5 & 87.4 & 91.1 \\
\hline 33 & 90.5 & 87.0 & 87.0 & 82.8 \\
\hline 34 & 87.0 & 87.1 & 86.2 & 87.2 \\
\hline 35 & 92.2 & 91.3 & 89.8 & 91.2 \\
\hline 36 & 88.5 & 90.9 & 91.2 & 92.6 \\
\hline 37 & 91.6 & 91.5 & 91.4 & 91.6 \\
\hline 38 & 93.4 & 94.3 & 93.4 & 96.0 \\
\hline 39 & 84.3 & 89.4 & 87.0 & 89.3 \\
\hline 40 & 96.0 & 93.6 & 92.4 & 95.2 \\
\hline \hline
\end{tabular}

\begin{tabular}{|c|c|c|c|c|}
\hline \multicolumn{5}{|c|}{$\begin{array}{l}\text { Table } 3-20 \\
\text { Analysis of Variance for Percent Passing the } 3 / 4 \text {-in. Sieve }\end{array}$} \\
\hline $\begin{array}{l}\text { Source of } \\
\text { Variability }\end{array}$ & $\begin{array}{l}\text { Degrees of } \\
\text { Freedom }\end{array}$ & $\begin{array}{l}\text { Sum of } \\
\text { Squares }\end{array}$ & Mean Square & $\begin{array}{l}\text { Expected } \\
\text { Mean Square }\end{array}$ \\
\hline Batch & $p-1=39$ & 536.62 & 13.760 & $\begin{array}{l}\sigma_{1}{ }^{2}+s\left(\sigma_{2}{ }^{2}\right)+ \\
\text { rs }\left(\sigma_{0}{ }^{2}\right)\end{array}$ \\
\hline Sample (batch) & $p(r-1)=40$ & 200.52 & 5.013 & $a_{1}^{2}+s\left(0,{ }_{1}^{2}\right)$ \\
\hline Error & $\operatorname{pr}(s-1)=80$ & 220.44 & 2.756 & $\sigma_{1}^{2}$ \\
\hline Corrected total & prs-1 $=159$ & 957.58 & N/A & N/A \\
\hline \multicolumn{5}{|c|}{$\begin{array}{l}1 \mathrm{p}=\text { Number of batches, } r=\text { number of samples per batch. } \\
\mathrm{s}=\text { Number of tests per sample. } \\
{ }^{2} \sigma_{0}^{2}=\text { Variance between batches, } \sigma_{s}{ }^{2}=\text { variance attributable to sampling. } \\
\sigma_{t}^{2}=\text { Variance attributable to testing plus inherent variability. } \\
\text { N/A No calculation. }\end{array}$} \\
\hline
\end{tabular}

\begin{tabular}{||l|l|l||}
\hline \hline \multicolumn{2}{||l||}{$\begin{array}{l}\text { Table 3-21 } \\
\text { Components of Variance for Percent Passing the 19-mm Sieve }\end{array}$} \\
\hline \hline & $\begin{array}{l}\text { Variance in Units of Percent } \\
\text { Squared }\end{array}$ & $\begin{array}{l}\text { Component Percent of } \\
\text { Total Variance }\end{array}$ \\
\hline \hline Source of Variability & 2.19 & 36 \\
\hline $\begin{array}{l}\text { Between batches } \\
\text { inheriment) }\end{array}$ & 2.76 & 45 \\
\hline Sampling & 1.13 & 19 \\
\hline Within batches & $2.76+1.13=3.89$ & $45+19=64$ \\
\hline Overall & $3.89+2.19=6.08$ & $64+36=100$ \\
\hline \hline Overall coefficient of variation $=(\sqrt{ } 6.08 / 90) \cdot 100$ percent $=2.7$ percent. \\
\hline
\end{tabular}




\section{Historical Variability Data}

As part of this study, a literature review was performed to collect variability data related to pavement materials and pavement structures. These data are necessary for the proper development of specification criteria, including pay adjustment factors. Details concerning the data found in literature, including references, are presented in Appendices B through F. This chapter serves as a summary for the appendices.

The material variabilities reported in this chapter involved a single laboratory. Variabilities associated with multiple laboratories would typically not be an issue for project quality testing. Since contractor pay is typically calculated for individual lots on a paving project, the variabilities reported in this chapter are intended to reflect total within-lot variabilities. Total withinlot variabilities include between-batch variabilities, between-sample variabilities, and experimental variation (testing and inherent).

When several estimates for variability were provided by the same source, variances were "pooled" into a single estimate as described in Chapter 2. If the number of replicates for variance estimates were not given, pooling of variances was performed as a straight average (replicates were assumed to all be equal).

Material variabilities are summarized in this chapter with both reported standard deviations (SDs) and coefficients of variation (CVs). Reported variabilities for any particular material property followed one of three trends with respect to the property mean:

a. As the mean increased, the standard deviation remained approximately constant while the coefficient of variation decreased.

$b$. As the mean increased, the coefficient of variation remained approximately constant while the standard deviation increased.

c. The range of reported means was too small to decipher these trends.

If $\mathrm{SD}$ remained approximately constant, $\mathrm{SD}$ is summarized as a single value and $\mathrm{CV}$ is summarized as a range. If CV remained approximately constant, $\mathrm{CV}$ is summarized as a single value and $\mathrm{SD}$ is summarized as a range. If the 
range of reported means was too small to decipher these trends, SD and CV are both summarized as single values.

Any comments found in literature concerning the normality of data are included in this chapter. In most cases, these comments are just perceptions related to the shape of frequency distributions. However, in some cases, a normality test was performed. All reports for normality address individual test results. This chapter does not address any distributions for sample means.

\section{Residual Fine-Grained Soil Deposits}

Krahn and Fredlund (1983) reported on several soil deposits in Canada. They noted a surprising consistency with respect to the variability of individual soil properties between deposits. This finding supports the logic behind collecting and summarizing variability data for use in future construction projects.

The measured properties within a "lot" (uniform deposit) of residual soil typically exhibit coefficients of variation in the range of 10 to 30 percent (Table 4-1). Measured properties with relatively low variability include specific gravity of soil particles and dry density. Measured properties with relatively high variabilities include permeability, plasticity index, unconfined compressive strength, and shear box strength results. When soil strength tests require field sampling and transportation of these samples to a laboratory, the variability of measured strength is highly dependent on sampling technique (Kay and Krizek 1972).

Some of the measured properties were reported to be non-normal: natural water content (percent), degree of saturation (percent), maximum dry density $\left(\mathrm{kg} / \mathrm{m}^{3}\right)$, and unconfined compressive strength $(\mathrm{kPa})$. Two of these properties can most likely attribute their deviations from normality to limiting numerical boundaries. Natural water contents $(w)$ cannot fall below 0 percent, so the distribution for a soil with a low mean $w$ would tend to exhibit a positive skew. Degree of saturation $(S)$ cannot exceed 100 percent, so the distribution for a soil with a high mean $S$ would tend to exhibit a negative skew. Unconfined compressive strength can most likely attribute its deviation from normality to heterogeneity induced by sampling. Sampling would have the potential to decrease measured strength, causing the distribution to . exhibit a negative skew.

\section{Engineered Fill}

The measured properties within a "lot" of engineered fill typically exhibit coefficients of variation in the range of 10 to 30 percent (Tables 4-2 and 4-3). Relative compaction had a low variability (approximately 5 percent), possibly because it is often used for payment. Contractors typically have 


\begin{tabular}{|c|c|c|c|}
\hline Property & $\begin{array}{l}\text { Standard } \\
\text { Deviation }\end{array}$ & $\begin{array}{l}\text { Coefficient of } \\
\text { Variation, Percent }\end{array}$ & Normality \\
\hline Specific gravity & N/A & 2 & normal' \\
\hline $\begin{array}{l}\text { Natural water content, } \\
\text { percent }\end{array}$ & 4 & $10-25$ & conflicts $^{2}$ \\
\hline Porosity & 0.05 & $10-20$ & normal' \\
\hline Void ratio & 0.15 & 20 & normal' \\
\hline $\begin{array}{l}\text { Degree of } \\
\text { saturation, percent }\end{array}$ & 8 & $7-15$ & not normal ${ }^{1}$ \\
\hline Dry density, $\mathrm{kg} / \mathrm{m}^{3}$ & 105 & 5 & not reported ${ }^{3}$ \\
\hline $\begin{array}{l}\text { Coefficient of } \\
\text { permeability, percent } \\
-80 \text { percent saturated } \\
-100 \text { percent saturated }\end{array}$ & $\begin{array}{l}\text { N/A } \\
\text { N/A }\end{array}$ & $\begin{array}{r}90 \\
700 \\
\end{array}$ & not reported ${ }^{3}$ \\
\hline Liquid limit & 4-15 & 20 & normal ${ }^{1}$ \\
\hline Plastic limit & $2-5$ & 15 & not reported ${ }^{3}$ \\
\hline Plasticity index & $3-10$ & 40 & not reported ${ }^{3}$ \\
\hline $\begin{array}{l}\text { Particles finer, percent } \\
\text { - No. } 40 \text { sieve } \\
- \text { No. } 200 \text { sieve } \\
-2 \mu \mathrm{m} \text { sieve } \\
\end{array}$ & $\begin{array}{l}15 \\
10 \\
10 \\
\end{array}$ & $\begin{array}{l}15 \\
20 \\
35 \\
\end{array}$ & not reported ${ }^{3}$ \\
\hline Compression index & $\begin{array}{l}0.030 \\
0.070 \\
\end{array}$ & 30 & not reported ${ }^{3}$ \\
\hline Swell index & 0.020 & $25-55$ & not reported ${ }^{3}$ \\
\hline $\begin{array}{l}\text { Optimum moisture } \\
\text { Content, percent }\end{array}$ & 5 & 20 & normal ${ }^{4}$ \\
\hline $\begin{array}{l}\text { Maximum dry density, } \\
\mathrm{kg} / \mathrm{m}^{3}\end{array}$ & 130 & 8 & not normal ${ }^{4}$ \\
\hline & & & IContinue \\
\hline $\begin{array}{l}\text { According to the chi-sq } \\
2 \text { Reports concerning no } \\
3 \text { Reports on variability } \\
4 \text { Based on the shapes o } \\
\text { N/A Limited data or not }\end{array}$ & $\begin{array}{l}\text { goodness-o } \\
\text { y conflicted. } \\
\text { t address no } \\
\text { ograms. } \\
\text { ted. }\end{array}$ & test. & \\
\hline
\end{tabular}




\begin{tabular}{|c|c|c|c|}
\hline Property & $\begin{array}{l}\text { Standard } \\
\text { Deviation } \\
\end{array}$ & $\begin{array}{l}\text { Coefficient of } \\
\text { Variation, Percent } \\
\end{array}$ & Normality \\
\hline $\begin{array}{l}\text { Unconfined compression } \\
\text { strength, } \mathrm{kPa}\end{array}$ & $7-190$ & 45 & not normal' \\
\hline $\begin{array}{l}\text { California bearing ratio, } \\
\text { percent }\end{array}$ & 3 & 25 & not reported \\
\hline Field vane, $\mathrm{kPa}$ & 8 & 30 & not reported \\
\hline $\begin{array}{l}\text { Undrained triax. Test } \\
-c \\
-\tan \phi\end{array}$ & $\begin{array}{l}\text { N/A } \\
\text { N/A }\end{array}$ & $\begin{array}{l}25 \\
20 \\
\end{array}$ & not reported \\
\hline $\begin{array}{l}\text { Drained triaxial test } \\
-\mathrm{C} \\
-\tan \phi\end{array}$ & $\begin{array}{l}\text { N/A } \\
\text { N/A }\end{array}$ & $\begin{array}{r}15 \\
2 \\
\end{array}$ & not reported \\
\hline $\begin{array}{l}\text { Drained shear box } \\
-\mathrm{c} \\
-\tan \phi\end{array}$ & $\begin{array}{l}\text { N/A } \\
\text { N/A }\end{array}$ & $\begin{array}{r}100 \\
30 \\
\end{array}$ & not reported \\
\hline $\begin{array}{l}\text { According to the chi-sq } \\
\text { Reports on variability di } \\
\text { N/A Limited data or not r }\end{array}$ & $\begin{array}{l}\text { goodness- } \\
\text { address n } \\
\text { ad. }\end{array}$ & $\begin{array}{l}\text { test. } \\
\text { ty. }\end{array}$ & \\
\hline
\end{tabular}

\begin{tabular}{|c|c|c|c|}
\hline \multicolumn{4}{|c|}{$\begin{array}{l}\text { Table } 4-2 \\
\text { Summary of Reported Variabilities for Compacted Fine-Grained } \\
\text { Soil Deposits }\end{array}$} \\
\hline Property & $\begin{array}{l}\text { Standard } \\
\text { Deviation } \\
\end{array}$ & $\begin{array}{l}\text { Coefficient of } \\
\text { Variation, Percent }\end{array}$ & Normality \\
\hline $\begin{array}{l}\text { Controlled moisture } \\
\text { content, percent }\end{array}$ & 2 & 20 & conflicts' \\
\hline $\begin{array}{l}\text { Relative } \\
\text { compaction, percent }\end{array}$ & 4 & 5 & conflicts' \\
\hline $\begin{array}{l}\text { Resilient } \\
\text { modulus, } \mathrm{MPa}\end{array}$ & 25 & 25 & not reported ${ }^{2}$ \\
\hline $\begin{array}{l}\text { California bearing ratio, } \\
\text { percent }\end{array}$ & $1-15$ & 30 & not reported ${ }^{2}$ \\
\hline $\begin{array}{l}\text { Modulus of subgrade } \\
\text { reaction, } \mathrm{MPa} / \mathrm{mm}\end{array}$ & N/A & 35 & not reported ${ }^{2}$ \\
\hline $\begin{array}{l}\text { Benkelman beam } \\
\text { deflections, mm }\end{array}$ & 0.35 & 25 & not reported ${ }^{2}$ \\
\hline Dynaflect tests, MPa & N/A & 35 & not reported ${ }^{2}$ \\
\hline
\end{tabular}




\begin{tabular}{|c|c|c|c|}
\hline \multicolumn{4}{|c|}{$\begin{array}{l}\text { Table 4-3 } \\
\text { Summary of Reported Variabilities for Lime-Soil Mixtures and } \\
\text { Soil-Cement }\end{array}$} \\
\hline Property & $\begin{array}{l}\text { Standard } \\
\text { Deviation }\end{array}$ & $\begin{array}{l}\text { Coefficient of } \\
\text { Variation, Percent }\end{array}$ & Normality \\
\hline $\begin{array}{l}\text { Unconfined compression } \\
\text { strength, Mpa }\end{array}$ & N/A & 10 & not reported' \\
\hline $\begin{array}{l}\text { Splitting-tensile strength, } \\
\mathrm{MPa}\end{array}$ & N/A & 10 & not reported' \\
\hline Flexural strength, MPa & N/A & 10 & not reported' \\
\hline
\end{tabular}

financial interest in meeting density requirements and this objective is facilitated by keeping density variabilities as low as possible. The CV for both controlled moisture content and California bearing ratio are in the same range as the corresponding values for residual soil. The CV for unconfined compressive strength, however, was lower for engineered fill than for residual soil.

Inspection of Tables 4-2 and 4-3 also reveals that conflicts existed for some of the reports on normality. These conflicts were present for both controlled moisture content (percent) and relative compaction (percent). The tendency for these distributions to be skewed may be affected by mean value and variability. Controlled moisture content would tend to exhibit a normal distribution when the mean is far removed from the numerical limit of zero. Relative compaction would tend to exhibit a normal distribution when the variability is low. A high variability for relative compaction with a mean value close to 100 percent would tend to induce a negative skew.

\section{Subbase and Base Course Materials}

The liquid limit and plasticity index for untreated subbase and base course materials have SDs that are approximately the same as for the fine-grained soils. The lower mean values for these properties for subbase and base courses, however, cause the CVs to be higher than for the fine-grained soil (Table 4-4). Similar to fine-grained soil, permeability measurements for subbase and base course materials are highly variable. Standard deviations (SDs) for percent passing individual sieve sizes range from approximately 1 percent to 5 percent, while the CVs for percent passing individual sieve sizes range from approximately 5 percent to 50 percent. Measurement with fine sieves tend to have the highest CVs because they have the lowest mean values for percent passing. Finer sieve sizes also tend to be susceptible to errors induced by sampling method, screen cleanliness, and skill of the 


\begin{tabular}{|c|c|c|c|}
\hline \multicolumn{4}{|c|}{$\begin{array}{l}\text { Table } 4-4 \\
\text { Summary of Reported Variabilities for Subbase and Base Course } \\
\text { Materials }\end{array}$} \\
\hline Property & $\begin{array}{l}\text { Standard } \\
\text { Deviation } \\
\end{array}$ & $\begin{array}{l}\text { Coefficient of } \\
\text { Variation, Percent } \\
\end{array}$ & Normality \\
\hline $\begin{array}{l}\text { Controlled moisture content, } \\
\text { percent }\end{array}$ & 1 & 10 & not reported' \\
\hline Liquid limit, percent & 5 & $10-80$ & not reported' \\
\hline Plasticity index, percent & 2 & $25-65$ & not normal ${ }^{2}$ \\
\hline $\begin{array}{l}\text { Coefficient of permeability, } \\
\text { percent } \\
\text { - silty sand }\end{array}$ & N/A & 240 & not reported' \\
\hline $\begin{array}{l}\text { Particles finer, percent } \\
-19-\mathrm{mm} \text { sieve } \\
-13.2-\mathrm{mm} \text { sieve } \\
-9.5-\mathrm{mm} \text { sieve } \\
\text { - No. } 4 \text { sieve } \\
\text { - No. } 8 \text { sieve } \\
\text { - No. } 16 \text { sieve } \\
\text { - No. } 30 \text { sieve } \\
\text { - No. } 50 \text { sieve } \\
\text { - No. } 100 \text { sieve } \\
\text { - No. } 200 \text { sieve } \\
\end{array}$ & $\begin{array}{l}3 \\
2 \\
5 \\
5 \\
3 \\
4 \\
3 \\
3 \\
2 \\
1 \\
\end{array}$ & $\begin{array}{r}3-10 \\
3 \\
3-20 \\
4-20 \\
5-15 \\
20-25 \\
10 \\
5-25 \\
30-45 \\
5-25 \\
\end{array}$ & not reported \\
\hline Sand equivalence, percent & 5 & 15 & not reported ${ }^{1}$ \\
\hline $\begin{array}{l}\text { Magnesium sulfate } \\
\text { soundness, percent }\end{array}$ & $0.20-1.5$ & 3 & not reported' \\
\hline $\begin{array}{l}\text { Lift thickness, mm } \\
\text { - subbase } \\
\text { - base }\end{array}$ & $\begin{array}{l}8 \cdot 55 \\
5-30 \\
\end{array}$ & $\begin{array}{l}35 \\
15 \\
\end{array}$ & not reported' \\
\hline $\begin{array}{l}\text { Relative } \\
\text { compaction, percent } \\
\text { - subbase } \\
\text { - base }\end{array}$ & $\begin{array}{l}3 \\
2 \\
\end{array}$ & $\begin{array}{l}3 \\
2 \\
\end{array}$ & not reported \\
\hline Angle of internal friction, $\phi$ & N/A & 10 & not reported' \\
\hline $\begin{array}{l}\text { Unconfined compression } \\
\text { strength, } \mathrm{kPa}\end{array}$ & N/A & 10 & not reported ${ }^{3}$ \\
\hline $\begin{array}{l}\text { California bearing ratio } \\
\text { (field), percent }\end{array}$ & $8-35$ & 25 & not reported' \\
\hline $\begin{array}{l}\text { Benkelman beam } \\
\text { deflections, } \mathrm{mm}\end{array}$ & 0.25 & 20 & not reported' \\
\hline
\end{tabular}


technician (Michigan State Department of Highways 1966). Similar to the fine-grained soils, relative compaction had a low variability.

Tests for mechanical properties for subbase and base course materials tend to have high variabilities, as shown in Tables 4-5 and 4-6. Laboratory tests for modulus, Poisson's ratio, and fatigue properties had particularly high variabilities. The plate-load test, which is performed in the field, also had a particularly high variability.

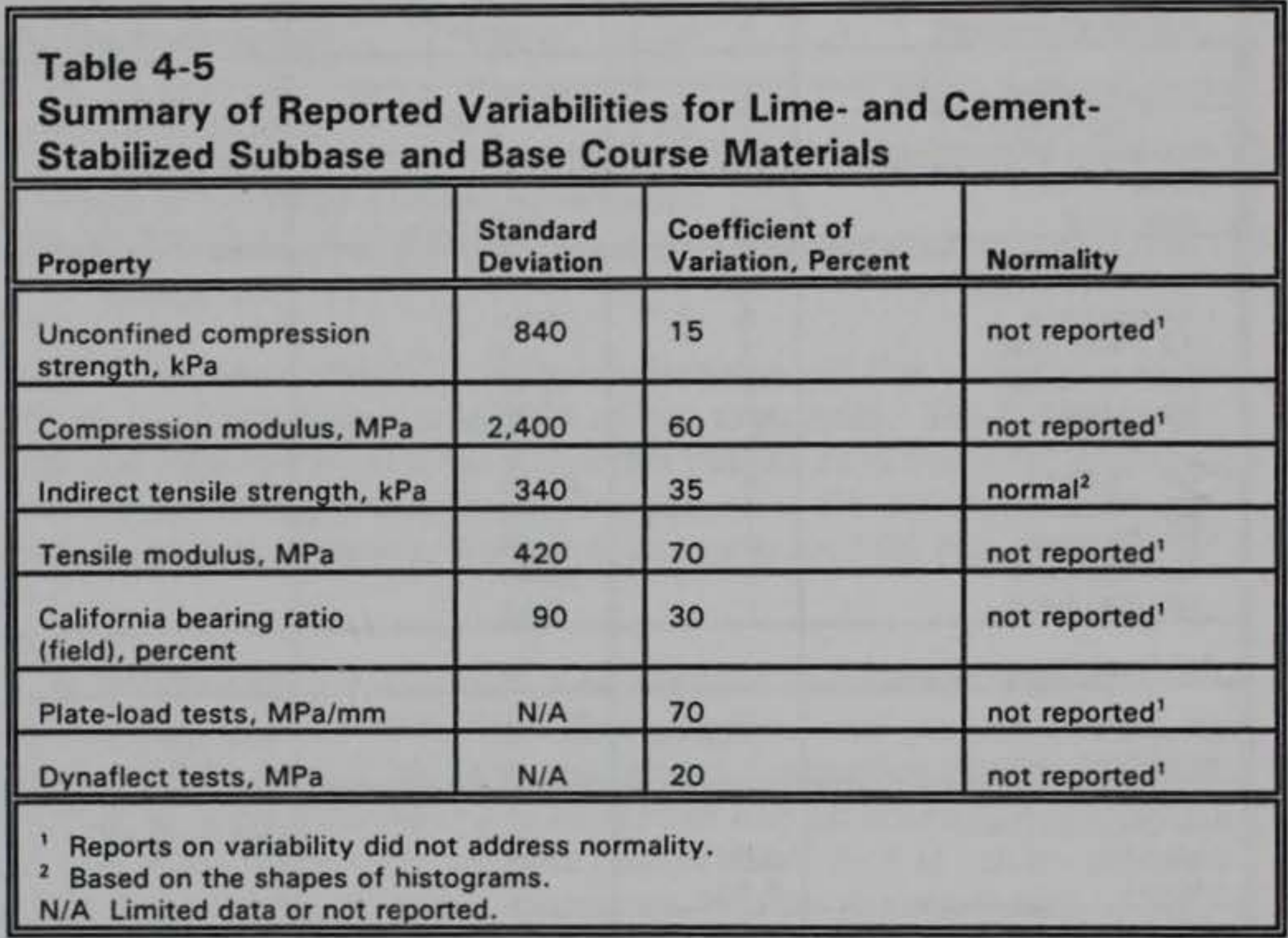

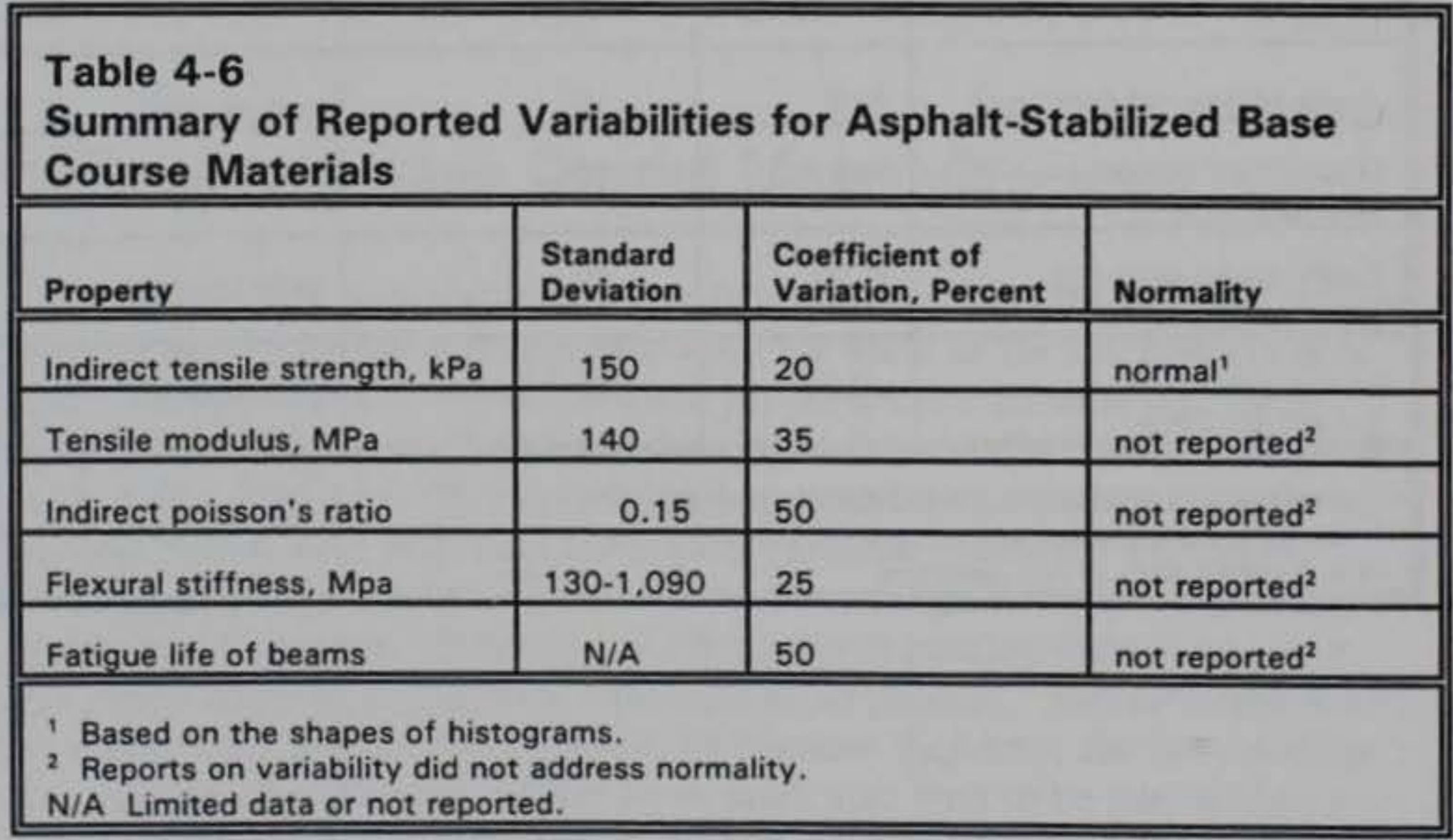




\section{Asphalt Concrete}

Penetration measurements for asphalt cement had lower CVs than capillary viscosity measurements, as shown in Table 4-7.

Standard deviations for percent passing individual sieve sizes for asphalt concrete aggregates, as shown in Table 4-8, were very similar to those for subbase and base course materials. The CVs for bulk specific gravity, maximum theoretical gravity, and field density were all relatively low. The CV for voids total mix was high due to the small mean values (typically 3 to 6 ). Similar to stabilized subbase and base course materials, measurements of modulus, Poisson's ratio, and fatigue had high variabilities.

For field tests, deflections measured by a falling-weight deflectometer (FWD) were generally less variable than deflections measured by a Benkelman beam (Table 4-9). Backcalculated moduli for FWD were least variable for the subgrade and most variable for asphalt concrete.

Table 4-7

Summary of Reported Variabilities for Asphalt Cement

\begin{tabular}{||l|l|l|l||}
\hline Property & $\begin{array}{l}\text { Standard } \\
\text { Deviation }\end{array}$ & $\begin{array}{l}\text { Coefficient of } \\
\text { Variation, Percent }\end{array}$ & Normality \\
\hline $\begin{array}{l}\text { Penetration at } 25^{\circ} \mathrm{C}, \\
0.01 \mathrm{~mm}\end{array}$ & $2-20$ & 25 & not reported' \\
\hline Viscosity at $60^{\circ} \mathrm{C}, \mathrm{Pa}-\mathrm{S}$ & $240-1270$ & 55 & not reported' \\
\hline \hline \\
\hline
\end{tabular}

\section{Portland Cement Concrete}

The SDs for percent passing large aggregate sieve sizes is typically larger for portland cement concrete (PCC) than for asphalt concrete (AC), as shown in Table 4-10. This trend may be a reflection of the less strict aggregate control requirements for PCC construction, as compared to AC construction. Ready-mix PCC plants typically include only two aggregate feed bins, while asphalt plants typically include four bins.

The average reported $\mathrm{CV}$ for compressive strength was 15 percent, as shown in Table 4-11. This value reflects favorable quality control according to Baker and McMahon (1969). In cases of poor quality control, CV for compressive strength exceeds 25 percent. The average reported CV for flexural strength was 7 percent, which reflects favorable quality control according to Witczak et al. (1983). In cases of poor quality control, CV for flexural strength exceeds 20 percent. 


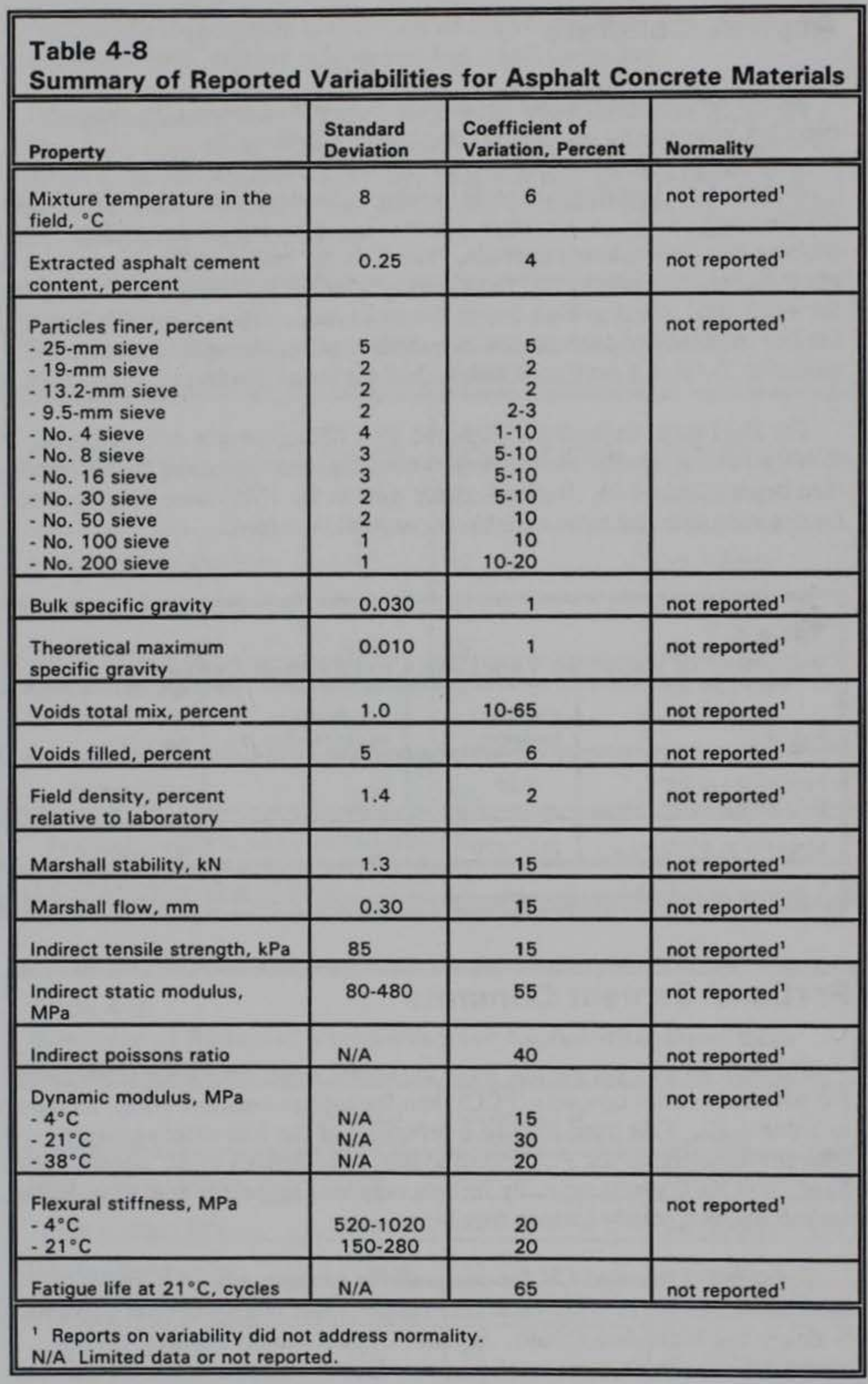




\begin{tabular}{|c|c|c|c|}
\hline \multicolumn{4}{|c|}{$\begin{array}{l}\text { Table 4-9 } \\
\text { Summary of Reported Variabilities for Field Measurements on } \\
\text { Asphalt Pavements }\end{array}$} \\
\hline Property & $\begin{array}{l}\text { Standard } \\
\text { Deviation } \\
\end{array}$ & $\begin{array}{l}\text { Coefficient of } \\
\text { Variation, Percent }\end{array}$ & Normality \\
\hline Mat thickness, mm & 8 & 10 & not reported' \\
\hline $\begin{array}{l}\text { Benkelman beam } \\
\text { deflections, } \mathrm{mm}\end{array}$ & 2 & $15-70$ & not normal ${ }^{2}$ \\
\hline $\begin{array}{l}\text { Falling weight deflectometer } \\
\text { (FWD) } \\
\text { Deflections } \\
\text { under load, } \mu \mathrm{m} \\
\text {-at } 0.9 \mathrm{~m} \text { offset, } \mu \mathrm{m} \\
\end{array}$ & $\begin{array}{c}30-340 \\
8-30 \\
\end{array}$ & $\begin{array}{l}15 \\
15 \\
\end{array}$ & normal ${ }^{2}$ \\
\hline $\begin{array}{l}\text { Falling weight deflectometer } \\
\text { (FWD) } \\
\text { Modulus calculations } \\
\text { - AC modulus, } \mathrm{MPa} \\
\text { - base modulus, } \mathrm{MPa} \\
\text { - subgrade modulus, } \mathrm{MPa} \\
\end{array}$ & $\begin{array}{c}210-3450 \\
20-240 \\
2-115 \\
\end{array}$ & $\begin{array}{l}50 \\
40 \\
15 \\
\end{array}$ & not normal $\left.\right|^{2}$ \\
\hline Initial serviceability index & 0.35 & 8 & normal $\left.\right|^{3}$ \\
\hline
\end{tabular}

Coefficients of variation for load transfer ranged from 20 to 55 percent. Tied contraction joints had the lowest variability. Keyed construction joints and doweled contraction joints had the highest variabilities. Variabilities in falling weight deflectometer (FWD) deflections and FWD moduli were similar to those for flexible pavements.

Frequency distributions for most of the fresh and hardened concrete properties have been reported to be normal in shape, as shown in Tables 4-10 and 4-11. The measured air content of air-entrained fresh concrete was an exception; its distribution was reported to have a negative skew. The FWD moduli were also an exception; in some cases they exhibited positive skew. 


\begin{tabular}{|c|c|c|c|}
\hline \multicolumn{4}{|c|}{$\begin{array}{l}\text { Table 4-10 } \\
\text { Summary of Reported Variabilities for Portland Cement Concrete } \\
\text { Materials }\end{array}$} \\
\hline Property & $\begin{array}{l}\text { Standard } \\
\text { Deviation }\end{array}$ & $\begin{array}{l}\text { Coefficient of } \\
\text { Variation, Percent }\end{array}$ & Normality \\
\hline Air content, percent & 0.85 & 15 & not normal' \\
\hline Slump, mm & $8-25$ & 30 & normal' ${ }^{1}$ \\
\hline $\begin{array}{l}\text { Particles finer, percent } \\
\text { (coarse aggregates) } \\
-25-\mathrm{mm} \text { sieve } \\
-19-\mathrm{mm} \text { sieve } \\
-13.2-\mathrm{mm} \text { sieve } \\
\text { - No. } 4 \text { sieve } \\
\text { No. } 8 \text { sieve } \\
\end{array}$ & $\begin{array}{r}3 \\
10 \\
10 \\
1 \\
1 \\
\end{array}$ & $\begin{array}{r}2-4 \\
4-20 \\
15-35 \\
45-90 \\
65 \\
\end{array}$ & normal' \\
\hline $\begin{array}{l}\text { Particles finer, percent } \\
\text { (fine aggregates) } \\
\text { - No. } 4 \text { sieve } \\
\text { - No. } 8 \text { sieve } \\
\text { - No. } 16 \text { sieve } \\
\text { - No. } 30 \text { sieve } \\
\text { - No. } 50 \text { sieve } \\
\text { - No. } 100 \text { sieve } \\
\end{array}$ & $\begin{array}{l}1 \\
3 \\
4 \\
4 \\
5 \\
1 \\
\end{array}$ & $\begin{array}{r}1 \\
3 \\
6 \\
9 \\
15-40 \\
20-60 \\
\end{array}$ & normal' \\
\hline Fineness modulus & 0.10 & 4 & normal' \\
\hline
\end{tabular}




\begin{tabular}{|c|c|c|c|}
\hline \multicolumn{4}{|c|}{$\begin{array}{l}\text { Table 4-11 } \\
\text { Summary of Reported Variabilities for Hardened Portland Cement } \\
\text { Concrete }\end{array}$} \\
\hline Property & $\begin{array}{l}\text { Standard } \\
\text { Deviation } \\
\end{array}$ & $\begin{array}{l}\text { Coefficient of } \\
\text { Variation, Percent } \\
\end{array}$ & Normality \\
\hline $\begin{array}{l}\text { Density in hardened state, } \\
\mathrm{kg} / \mathrm{m}^{3}\end{array}$ & N/A & 2 & not reported' \\
\hline Compressive strength, $\mathrm{MPa}$ & 4 & 15 & normal $\left.\right|^{2}$ \\
\hline Compressive modulus, $\mathrm{MPa}$ & N/A & 30 & not reported' \\
\hline Poisson's ratio & N/A & 15 & not reported' \\
\hline Indirect tensile strength, $\mathrm{kPa}$ & 570 & 15 & normal $\left.\right|^{2}$ \\
\hline $\begin{array}{l}\text { Indirect tensile modulus, } \\
\mathrm{MPa}\end{array}$ & 8720 & 35 & normal ${ }^{2}$ \\
\hline Flexural strength, $\mathrm{kPa}$ & 350 & 7 & normal ${ }^{2}$ \\
\hline Slab thickness, $\mathrm{mm}$ & 9 & 3 & normal ${ }^{2}$ \\
\hline $\begin{array}{l}\text { Load transfer, percent } \\
\text { - doweled expansion } \\
\text { - doweled construction } \\
\text { - keyed construction } \\
\text { - doweled contraction } \\
\text { - tied contraction } \\
\text { - plain contraction } \\
\end{array}$ & $\begin{array}{r}7 \\
5 \\
10 \\
4 \\
5 \\
4 \\
\end{array}$ & $\begin{array}{r}25 \\
25 \\
40 \\
4-55 \\
20 \\
25 \\
\end{array}$ & conflicts $^{3}$ \\
\hline $\begin{array}{l}\text { Falling weight deflectometer } \\
\text { (FWD) } \\
\text { Deflections } \\
\text { - under load, } \mu \mathrm{m} \\
\end{array}$ & $3-120$ & 15 & normal $\left.\right|^{2}$ \\
\hline $\begin{array}{l}\text { Falling weight deflectometer } \\
\text { (FWD) } \\
\text { Modulus calculations } \\
\text { - PCC modulus, MPa } \\
\text { - subgrade modulus, MPa } \\
\end{array}$ & $\begin{array}{c}2830-15740 \\
15-30 \\
\end{array}$ & $\begin{array}{l}30 \\
15 \\
\end{array}$ & not reported' \\
\hline Serviceability index & 0.15 & 3 & normal ${ }^{2}$ \\
\hline
\end{tabular}




\section{Summary, Conclusions, and Recommendations}

\section{Summary and Conclusions}

The paving industry is moving forward with performance-related specifications that incorporate statistical concepts for the development of acceptance plans, including quality control and quality assurance testing. Personnel involved in pavement construction need to understand these statistical concepts and they need to know the levels of variability that should be expected in their test results.

This report provides information on statistical methods that can be used by pavement engineers and contractors to analyze the variability of construction materials. In addition, it summarizes selected published data on these variabilities. These data were measured within "lots" of material, where a lot is defined as a quantity of material that can be considered uniform for sampling and payment purposes.

The methods for analyzing variability will be useful for those who need to quantify the relative magnitudes of different sources of variation. If a contractor's product is highly variable, these methods can be used to determine if the production of materials is out of control or if the methods for sampling and/or testing are inconsistent. By keeping track of the trends in test results, the contractor will be able to adjust production and/or construction methods as necessary in order to provide a high-quality, consistent product.

The data pertaining to published variabilities provide the pavement designer and specification writer with tools for determining what can be reasonably expected of the contractor. A contractor cannot be expected to keep material variation well below the published norm. Some sources of variability, such as those inherent to a particular test method, are out of the contractor's control. Knowledge of expected variability will also help the owner control two important aspects of specifications: the risks for contractual parties and the reliability of the final product. 


\section{Recommendations}

The purpose of this report was to review statistical concepts and compile data related to the variability of materials used for the construction of pavements. Based on the concepts presented and data reviewed, the following actions are recommended.

$a$. The current Corps of Engineers specification requirements for pavement construction should be reviewed to determine the appropriateness of the statistical concepts incorporated.

$b$. Where necessary, the Corps of Engineers specifications should be adjusted to reflect reasonable expectations of the contractor so that the risks assumed by the contractor and owner are equitable.

c. Corps of Engineer specifications that do not contain statistical concepts for acceptance testing should be modified. 


\section{Bibliography}

Adams, V. and Shah, S. C. (1965). "Quality control analysis of asphaltic concrete," Proceedings, Highway Conference on Research and Development of Quality Control and Acceptance Specifications, U.S. Department of Commerce, Bureau of Public Roads.

American Association of State Highway and Transportation Officials (AASHTO). (1992). AASHTO Guide for Design of Pavement Structures, Washington, D.C.

American Association of State Highway and Transportation Official (AASHTO). (1995). Standard Specifications for Transportation Materials and Methods of Sampling and Testing, Part I: Specifications, Seventeenth Edition, Washington, D.C.

American Society for Testing and Materials (ASTM). (1995a). Annual Book of ASTM Standards, Vol. 04.02 (Concrete and Aggregates), Philadelphia, Pennsylvania.

American Society for Testing and Materials (ASTM). (1995b). Annual Book of ASTM Standards, Vol. 14.02 (General Test Methods), Philadelphia, Pennsylvania.

Attoh-Okine, N. O. and Roddis, W. M. K. (1994). "Pavement thickness variability and its effect on determination of moduli and remaining life," Transportation Research Record 1449, Transportation Research Board, National Academy Press, Washington, D.C., pp. 39-45.

Auff, A. A. and Choummanivong, L. (1994). "Construction variability mount gambier trial section,” Research Report ARR 258, Australian Road Research Board, Victoria, Australia, 20 pp.

Auff, A. A. and Laksmanto, H. (1993). "Construction variability - newell highway trial section," Research Report ARR 244, Australian Road Research Board, Victoria, Australia, 29 pp.

Auff, A. A. and Laksmanto, H. (1994). "Construction variability - calder highway trial section," Research Report ARR 253, Australian Road Research Board, Victoria, Australia, 32 pp. 
Auff, A. A. and Yeo, R. (1992). "Construction variability - benalla test section," Research Report ARR 220, Australian Road Research Board, Victoria, Australia, 24 pp.

Baecher, G. (1987). "Statistical quality control of engineered Embankments," Contract Report GL-87-2, Waterways Experiment Station, U.S. Army Corps of Engineers, Vicksburg, MS, 167 pp.

Baker, R. F. (1966). "Broad aspects of statistical quality control," National Conference on Statistical Quality Control Methodology in Highway and Airfield Construction, Proceedings, University of Virginia, Charlottesville, Virginia, pp. 591-598.

Baker, W. M. and McMahon, T. F. (1969). "Quality assurance in highway construction," Part 3 - Quality Assurance of Portland Cement Concrete, Public Roads, Vol. 35, No. 8, Bureau of Public Roads, Federal Highway Administration, U.S. Department of Transportation, Washington, D.C., pp. 184-189.

Ballard, G. E. H. and Weeks, W. F. (1963). "The human factor in determining the plastic limit of cohesive soils," Materials Research and Standard, Vol. 3, No. 9, American Society for Testing and Materials, pp. 726-729.

Benjamin, J. and Cornell, C. A. (1970). Probability, Statistics, and Decision for Civil Engineers, McGraw-Hill Book Company, New York.

Benson, J. J. (1966). "The equipment manufacturer and the philosophy of statistical quality control," National Conference on Statistical Quality Control Methodology in Highway and Airfield Construction, Proceedings, University of Virginia, Charlottesville, Virginia, pp. 623-627.

Brown, E. R. (1973). "Statistical quality control procedures for airport pavement materials," Report No. FAA-RD-73-199, prepared for the Federal Aviation Administration, U.S. Department of Transportation, conducted at the U.S. Army Engineer Waterways Experiment Station, Corps of Engineers, 92 pp.

Brown, E. R. (1975). "Statistical quality control procedures for airport pavement materials," U.S. Army Engineer Waterways Experiment Station Report, FAA-RD-199, Federal Aviation Administration, Washington, DC.

Brown, H. E. (1966). "Application of statistical evaluation techniques for quality control of steam cured concrete," National Conference on Statistical Quality Control Methodology in Highway and Airfield Construction, Proceedings, University of Virginia, Charlottesville, Virginia, pp. 343-372. 
C. G. R. A. Special Committee on Pavement Design and Evaluation. (1962). "Pavement evaluation studies in Canada," Proceedings of the International Conference on the Structural Design of Asphalt Pavements, Ann Arbor, Michigan.

Chou, Y. T. (1986). "Probabilistic and reliability analysis of the California Bearing Ratio (CBR) design method for flexible airfield pavements," Technical Report GL-86-15, U.S. Army Engineer Waterways Experiment Station, Vicksburg, Mississippi.

Chou, Y. T. (1987). "Probabilistic and Reliability Analysis for Flexible airfield pavements - elastic layered method," Technical Report GL-87-24, U.S. Army Engineer Waterways Experiment Station, Vicksburg, Mississippi.

Coleman, H. W. and Steele, W. G., Jr. (1989). Experimentation and Uncertainty Analysis for Engineers, John Wiley \& Sons, New York, $205 \mathrm{pp}$.

Cominsky, R. J. (1974a). "Session 16: sampling for quality control," Statistical Quality Control of Highway Construction, The Pennsylvania State University, University Park, Pennsylvania, pp. 16.1-16.33.

Cominsky, R. J. (1974b). "Session 18: development of acceptance plans," Statistical Quality Control of Highway Construction, The Pennsylvania State University, University Park, Pennsylvania, pp. 18.1-18.37.

Darter, M. I. (1973). Probabilistic Design Concepts Applied to Flexible Pavement System Design, Dissertation, The University of Texas at Austin, Austin, Texas, 200 pp.

Darter, M. I., Hudson, W. R., and Brown, J. L. (1973). "Statistical variations of flexible pavement properties and their consideration in design," Asphalt Paving Technology, Association of Asphalt Paving Technologists, Vol. 42, pp. 589-614.

David, J. H. (1967). “Quality control of construction by statistical tolerances," Alabama Highway Department.

Dillard, J. H. (1966). "Session II summary report," National Conference on Statistical Quality Control Methodology in Highway and Airfield Construction, Proceedings, University of Virginia, Charlottesville, Virginia, pp. $\mathrm{x}$-xii.

Fisher and Yates. (1949). Statistical Tables for Biological, Agricultural, and Medical Research, Oliver and Boyd, Ltd., Edinburgh. 
Fredlund, D. G. and Dahlman, A. E. (1972). "Statistical geotechnical properties of glacial lake edmonton sediments," Statistics and Probability in Civil Engineering, Proceedings of the First International Conference on Applications of Statistics and Probability to Soil and Structural Engineering, ed. Peter Lumb, Hong Kong University Press, distributed by Oxford University Press, London, pp. 203-228.

Finn, F. N. (1967). "Factors involved in the design of asphaltic pavement surfaces," Report No. 39, National Cooperative Highway Research Program, Highway Research Board.

Fordyce, P. and Teske, W. E. (1963). "Some relationships of the AASHO road test to concrete pavement design," Highway Research Record No. 44, Highway Research Board, Washington D.C., pp. 35-70.

Foster, C. R. and Stander, R. R. (1966). "Implications of statistical quality control from the contractor's viewpoint," National Conference on Statistical Quality Control Methodology in Highway and Airfield Construction, Proceedings, University of Virginia, Charlottesville, Virginia, pp. 629-633.

Fredlund, D. G. and Dahlman, A. E. (1972). "Statistical geotechnical properties of glacial lake edmonton sediments," Statistics and Probability in Civil Engineering, Proceedings of the First International Conference on Applications of Statistics and Probability to Soil and Structural Engineering, Hong Kong University Press, pp. 204-228.

Freund, R. J. and Wilson, W. J. (1993). Statistical Methods, Academic Press, Inc., Harcourt Brace Jovanovich, Publishers, Boston, 644 pp.

Gartner, W., Jr. (1965). "Testing variance for routine tests of highway materials," Proceedings, Highway Conference on Research and Development of Quality Control and Acceptance Specifications, U.S. Department of Commerce, Bureau of Public Roads, p. 244.

Gibeaut, D. R. (1960). “An investigation of young's modulus and poisson's ratio of portland cement concrete," A Thesis, Ohio State University.

Granley, E. C. (1969a). "Quality assurance in highway construction," Part 4 - Variations in Bituminous Construction, Public Roads, Vol. 35, No. 9, Bureau of Public Roads, Federal Highway Administration,

U.S. Department of Transportation, Washington, D.C., pp. 201-211.

Grant, E. L. and Leavenworth, R. S. (1988). Statistical Quality Control, McGraw-Hill, Inc., New York, 714 pp.

Grogan, W. P. (1991). "Development of a reliability-based method for evaluating a pavement feature," Technical Report GL-91-14, U.S. Army Engineer Waterways Experiment Station, Vicksburg, MS, 142 pp. 
Hammitt, G. M. (1966). "Statistical analysis of data from a comparative laboratory test program sponsored by ACIL," Miscellaneous Paper 4-785, U.S. Army Engineer Waterways Experiment Station, Vicksburg, MS.

Hammons, M. I., Pittman, D. W., and Mathews, D. D. (1995). "Field study of load transfer at rigid pavement Joints," Technical Report GL-95-7, U.S. Army Engineer Waterways Experiment Station, Vicksburg, MS, 90 pp.

Hampton, D., Yoder, E. J., and Burr, I. W. (1962). "Variability of engineering properties of brookston and crosby soils," Proceedings, Highway Research Board, Vol. 41, National Research Council, Washington, D.C., pp. 621-649.

Hanna, S. J., McLaughlin, J. F., and Lott, A. P. (1967). "Application of statistical quality control procedures to production of highway pavement concrete," Highway Research Record No. 160, Highway Research Board, National Research Council, Washington, D.C., pp. 1-14.

Harr, M. E. (1987). Reliability-Based Design in Civil Engineering, McGraw-Hill Book Company, New York, 290 pp.

Highway Research Board. (1962a). The AASHO Road Test: Report 2 Materials and Construction, Special Report 61B, Washington, DC.

Highway Research Board. (1962b). The AASHO Road Test: Report 5 Pavement Research, Special Report 61E, Washington, DC.

Hode-Keyser, J. and Wade, P. F. (1963). "Variability in the testing and production of bituminous mixtures," Highway Research Record No. 24, Highway Research Board, Washington, D.C., p. 195.

Houston, S. L. and Perera, R. (1991). "Impact of natural site variability on nondestructive test deflection basins," Journal of Transportation Engineering, Vol. 117, No. 5, American Society of Civil Engineers, pp. 550-565.

Huculak, N. A. (1968). "Quality Control of Asphalt Pavement Construction," Proceedings, The Association of Asphalt Paving Technologists, Vol. 37.

Hudson, W. R. (1975). "State-of-the-art in predicting pavement reliability from input variability," Contract Report S-75-7, U.S. Army Engineer Waterways Experiment Station, Vicksburg, Mississippi.

Hughes, C. S. and Anday, M. C., "An analysis of variations encountered in nuclear density testing," National Conference on Statistical Quality Control Methodology in Highway and Airfield Construction, Proceedings, University of Virginia, Charlottesville, Virginia, pp. 397-407. 
Ingles, O. G. (1972). "Statistical control in pavement design," Statistics and Probability in Civil Engineering, Proceedings of the First International Conference on Applications of Statistics and Probability to Soil and Structural Engineering, Hong Kong University Press, pp. 267-278.

Johnson, R. A. (1994). Miller and Freund's Probability and Statistics for Engineers, Fifth Edition, Prentice Hall, Englewood Cliffs, New Jersey, $630 \mathrm{pp}$.

Jorgenson, J. L. (1968). "The statistical approach to quality control in highway construction," North Dakota State University, Research Report No. 15, Engineering Experiment Station Series.

Kay, J. N. and Krizek, R. J. (1972). "Estimation of the mean for soil properties," Statistics and Probability in Civil Engineering, Proceedings of the First International Conference on Applications of Statistics and Probability to Soil and Structural Engineering, Hong Kong University Press, pp. 279-286.

Kelley, J. A. (1969). "Quality assurance in highway construction," Part 5 Summary of Research for Quality Assurance of Aggregates, Public Roads, Vol. 35, No. 10, Bureau of Public Roads, Federal Highway Administration, U.S. Department of Transportation, Washington, D.C., pp. 230-237.

Kennedy, T. W., Hudson, W. R., and McCullough, B. F. (1975). "Stateof-the-art in variability of material properties for airport pavement systems," Federal Aviation Administration report No. FAA-RD-75-209, monitored by U.S. Army Engineer Waterways Experiment Station, Corps of Engineers, Contract No. S-75-6, 82 pp.

Kerr, J. W. G. and Parkes, D. R. (1966). "Implications of statistical quality control after several years experience," National Conference on Statistical Quality Control Methodology in Highway and Airfield Construction, Proceedings, University of Virginia, Charlottesville, Virginia, pp. 635-662.

Keyser, J. H. and Wade, P. F. (1968). "Montreal's experience in the application of statistics in the specification and control of bituminous mixtures," Proceedings, The Association of Asphalt Paving Technologists, Vol. 37, p. 341.

Kher, R. K. and Darter, M. I. (1973). "Probability concepts and their applications to AASHO interim guide for design of rigid pavements, Highway Research Record No. 466, Highway Research Board, Washington, D.C., pp. 20-36.

Kilpatrick, M. J. and McQuate, R. G. (1967). "Bituminous pavement construction," Public Roads, June Issue, Bureau of Public Roads, pp. 19-23. 
Krahn, J. and Fredlund, D. G. (1983). "Variability in the engineering properties of natural soil deposits," Applications of Statistics and Probability in Soil and Structural Engineering, Proceedings of the Fourth International Conference, University of Florence, Italy, pp. 1017-1029.

Ladd, C. C., Moh, Z. C. and Gifford, D. G. (1972). "Statistical analysis of undrained strength of soft bangkok clay," Statistics and Probability in Civil Engineering, Proceedings of the First International Conference on Applications of Statistics and Probability to Soil and Structural Engineering, Hong Kong University Press, pp. 313-328.

Liu, T. K. and Thompson, M. R. (1966). "Variability of some selected laboratory soil tests," National Conference on Statistical Quality Control Methodology in Highway and Airfield Construction, Proceedings, University of Virginia, Charlottesville, Virginia, pp. 375-395.

Liu, T. K. and Thornburn, T. H. (1964). "Study of the reproducibility of atterberg limits," Highway Research Record No. 63, Highway Research Board, pp. 23-30.

Louisiana Department of Highways. (1966). "Quality control analysis," Part 3, Concrete and Concrete Aggregates, Research Report No. 24, Research Project No. 63-IG.

Lumb, P. (1966). "Variability of natural soils," Ganadian Geotechnical Journal, Vol. 3, May, pp.

Lumb, P. (1972). "Precision and accuracy of soil tests" Statistics and Probability in Civil Engineering, Proceedings of the First International Conference on Applications of Statistics and Probability to Soil and Structural Engineering, Hong Kong University Press, pp. 329-345.

Marshall, B. P. and Kennedy, T. W. (1974). "Tensile and elastic characteristics of pavement materials," Research Report 183-1, Center for Highway Research, The University of Texas at Austin.

McLaughlin, J. F. (1966). "Session IV summary report," National Conference on Statistical Quality Control Methodology in Highway and Airfield Construction, Proceedings, University of Virginia, Charlottesville, Virginia, pp. xv-xvi.

McMahon, T. F. (1969). "Quality assurance in highway construction," Part 2 - Quality Assurance of Embankments and Base Courses, Public Roads, Vol. 35, No. 7, Bureau of Public Roads, Federal Highway Administration, U.S. Department of Transportation, Washington, D.C., pp. 166-174. 
McMahon, T. F. and Halstead, W. J. (1969). "Quality assurance in highway construction," Part 1 - Introduction and Concepts, Public Roads, Vol. 35, No. 6, Bureau of Public Roads, Federal Highway Administration, U.S. Department of Transportation, Washington, D.C., pp. 129-134.

Michigan Department of Highways. (1966). "Highway quality control program, statistical parameters," Research Report No. R-572.

Mitchell, M. F., Semmelink, C. J., and McQueen, A. L. (1977). "Statistical quality assurance in highway engineering in South Africa," Transportation Research Record 652, Transportation Research Board, Washington, D.C., pp. 58-65.

Monismith, C. L., Sneed, H. B., Mitry, F. G., and Chang, C. K. (1967). "Prediction of pavement deflections from laboratory tests," Proceedings, Second International Conference on the Structural Design of Asphalt Pavements, University of Michigan, pp. 109-140.

Monismith, C. L. et al. (1970). "Asphalt mixture behavior in repeated flexure," Report TE 70-5, University of California, Berkeley.

Moore, R. K. and Kennedy, T. W. (1971). "Tensile behavior of subbase materials under repetitive loading," Research Report 98-12, Center for Highway Research, The University of Texas at Austin.

Morse, R. K. (1972). "The importance of proper soil units for statistical analysis," Statistics and Probability in Civil Engineering, Proceedings of the First International Conference on Applications of Statistics and Probability to Soil and Structural Engineering, Hong Kong University Press, pp. 348-355.

Moulthrop, J. S. (1974). "PennDOT overview of statistical quality control," Statistical Quality Control of Highway Construction, The Pennsylvania State University, University Park, Pennsylvania, pp. 1.1-1.14.

Neamen, D. and Laquros, J. G. (1967). "Statistical quality control in portland cement concrete pavements," Highway Research Record No. 184, Highway Research Board, Washington, DC.

Newlon, H. H. (1966). "Variability of portland cement concrete," National Conference on Statistical Quality Control Methodology in Highway and Airfield Construction, Proceedings, University of Virginia, Charlottesville, Virginia, pp. 259-284.

New York State Department of Public Works. (1964). "Salt soundness tests for fine aggregates." 
Nicotera, R. (1974). "Session 17: development of statistically based restricted performance specifications," Statistical Quality Control of Highway Construction, The Pennsylvania State University, University Park, Pennsylvania, pp. 17.1-17.25.

Nielsen, D. R., Biggar, J. W., and Erh, K. T. (1973). "Spatial variability of field-measured soil-water properties," Hilgardia, Journal of Agricultural Science, Vol. 42, Nov., pp. 215-260.

Nielson, G. F. (1967). "Characteristics of compacted bases and subbases," Utah State Highway Department.

Norusis, M. J. (1993). SPSS for Windows; Base System User's Guide; Release 6.0, SPSS, Inc., Chicago, IL, 828 pp.

Oglio, E. R. and Zenewitz, J. A. (1965). "A study of variability in an asphalt concrete mix," Proceedings, The Association of Asphalt Paving Technologists, Vol. 34, pp. 464-483.

Oklahoma Department of Highways. (1968). "Statistical quality control of portland cement concrete pavements," Study No. 64-02-2.

Ott. (1977). An Introduction to Statistical Methods and Data Analysis, Duxbury, 702 pp.

Padilla, J. D. and Vanmarcke, E. H. (1974). 'Settlement of structures on shallow foundations: a probabilistic analysis," Research Report R74-9, Massachusetts Institute of Technology, Cambridge, MA.

Petersen, R. G. (1985). Design and Analysis of Experiments, Marcel Dekker, Inc., New York, 429 pp.

Pittman, D. W. (1994). "Development of a Design Procedure for RollerCompacted Concrete (RCC) Pavements, ” Technical Report GL-94-6, U.S. Army Engineer Waterways Experiment Station, Vicksburg, Mississippi.

Pittman, D. W. (1995). "Development of a reliability-based design procedure for rigid and flexible airfield pavements," draft report.

Potter, J. C. (1985). "Reliability of the flexible pavement design model," Miscellaneous Paper GL-85-27, U.S. Army Engineer Waterways Experiment Station, Vicksburg, Mississippi.

Rethati, L. (1983). "Asymmetry in the distribution of soil properties and its elimination," Applications of Statistics and Probability in Soil and Structural Engineering, Proceedings of the Fourth International Conference, The University of Florence, Italy, pp. 1057-1070. 
Rodriguez-Gomez, J., Ferregut, C., and Nazarian, S. (1992). "Impact of variability in pavement parameters on backcalculated moduli," Road and Airport Pavement Response Monitoring Systems, edited by V. C. Janoo and R. A. Eaton, American Society of Civil Engineers, New York, NY, pp. 261-275.

Rollings, R. S. (1987). "Design of rigid pavement overlays," Federal Aviation Administration, Washington, DC.

SAS. (1988). SAS Procedures Guide, Release 6.03 Edition, SAS Institute Inc., $441 \mathrm{pp}$.

Schiff, D. and D'Agostino, R. B. (1996). Practical Engineering Statistics, John Wiley and Sons, Inc., New York, 309 pp.

Schultze, E. (1972). "Frequency distributions and correlations of soil properties," Statistics and Probability in Civil Engineering, Proceedings of the First International Conference on Applications of Statistics and Probability to Soil and Structural Engineering, ed. Peter Lumb, Hong Kong University Press, distributed by Oxford University Press, London, pp. 371-388.

Schultze, E. (1975). "The general significance of statistics for the civil engineer," Applications of Statistics and Probability in Soil and Structural Engineering, Proceedings of the Second International Conference, ed. Edgar Schultze, published by Deutsche Gesellschaft, Aachen, Germany, pp. 21-38.

Selig, E. T. (1966). "Variability of compacted soils," National Conference on Statistical Quality Control Methodology in Highway and Airfield Construction, Proceedings, University of Virginia, Charlottesville, Virginia, pp. 181-213.

Sherman, G. B. (1971). "In situ materials variability," Special Report 126, Highway Research Board, Washington, D.C., pp. 180-190.

Sherman, G. B., Watkins, R. O., and Prysock, R. (1966). "A statistical analysis of embankment compaction," State of California, Department of Public Works, Division of Highways.

Shook, J. F. (1966). "Variability in bituminous construction," National Conference on Statistical Quality Control Methodology in Highway and Airfield Construction, Proceedings, University of Virginia, Charlottesville, Virginia, pp. 249-258.

Shook, J. F, and Fang, H. Y. (1961). "A study of operator variability in the determination of liquid and plastic limits of soils," Highway Research Abstract, Vol. 3, No. 9, Highway Research Board, pp. 26-28. 
Siddharthan, R., Sebaaly, P. E., and Javaregowda, M. (1992). "Influence of statistical variation in falling weight deflectometers on pavement analysis," Transportation Research Record No. 1377, Transportation Research Board, Washington, D.C., pp. 57-66.

South Carolina State Highway Department (SCSHD). (1966). "Procedures for using statistical methods for process control and acceptance of bituminous mixtures," Prepared by Paquette-Mills, Consulting Engineers, Atlanta, GA.

Spiegel, M. R. (1988). Theory and Problems of Statistics, Schaum's Outline Series, Second Edition, McGraw-Hill Publishing Company, New York, 504 pp.

State of California. (1967). "A statistical analysis of untreated base and subbase materials," Department of Public Works, Division of Highways.

State of Idaho Department of Highways. (1967). "Quality control," Research Project No. 11

State Road Commission of West Virginia (SRCWV). (1966). "Determination of statistical parameters for highway construction," Research Project No. 18, prepared by Materials Research and Development, Inc., MillerWarden Associates Division, 49 pp.

Steel, R. G. D. and Torrie, J. H. (1980). Principles and Procedures of Statistics: A Biometrical Approach, Second Edition, McGraw-Hill Book Company, New York, 633 pp.

Sues, R. H., Lua, Y. J., Dass, S. M., Murfee, J. (1993). "Reliabilitybased analysis and design of flexible airfield pavements," Airport Pavement Innovations: Theory to Practice, American Society of Civil Engineers Conference Proceedings, New York, New York.

The Asphalt Institute. (1974). "Method of test for dynamic modulus of asphalt mixtures," College Park, Maryland.

The State Road Commission of West Virginia. (1968). "Determination of statistical parameters for highway construction," Research Project No. 18.

The State Road Department of Florida. (1965). "A study in the general field of quality control engineering."

Thompson, C. M. (1941). "Table of percentage points of the $\chi^{2}$ distribution," Biometrika, Vol. 32, pp. 188-189.

Tietjen, G. L. and Moore, R. H. (1972). "Some grubbs-type statistics for the detection of several outliers," Technometrics, TCNTA, Vol. 14, No. 3, pp. 583-597. 
Transportation Research Board (TRB). (1996). "Glossary of highway quality assurance terms," Transportation Research Circular, Number 457, Transportation Research Board, 18 pp.

Van Houten, F. C. (1967). "Characteristics of compacted embankments," Utah State Highway Department.

Wahls, H. E. and Futrell, G. E. (1966). "A comparison of soil classification systems by analysis of variance," National Conference on Statistical Quality Control Methodology in Highway and Airfield Construction, Proceedings, University of Virginia, Charlottesville, Virginia, pp. 301-340.

Waller, H. F., Jr. (1966). "Stockpiling of aggregate for gradation uniformity," National Conference on Statistical Quality Control Methodology in Highway and Airfield Construction, Proceedings, University of Virginia, Charlottesville, Virginia, pp. 215-248.

Weed, R. M. (1982). "Statistical specification development," New Jersey Department of Transportation, Report No. FHWA/NJ-83/007, Federal Highway Administration, Washington, D.C., 315 pp.

Willenbrock, J. H. (1974a). "Session 3: sampling experiment No. 1," Statistical Quality Control of Highway Construction, The Pennsylvania State University, University Park, Pennsylvania, pp. 3.1-3.6.

Willenbrock, J. H. (1974b). "Session 6: additional aspects of statistical analysis," Statistical Quality Control of Highway Construction, The Pennsylvania State University, University Park, Pennsylvania, pp. 6.1-6.35.

Willenbrock, J. H. (1974c). "Session 12: statistical test for normality," Statistical Quality Control of Highway Construction, The Pennsylvania State University, University Park, Pennsylvania, pp. 12.1-12.9.

Williamson, T. G. and Yoder, E. J. (1967). "An investigation of compaction variability for selected highway projects in Indiana," Purdue University, Indiana State Highway Commission.

Witczak, M. W., Uzan, J., Johnson, M. (1983). "Development of probabilistic rigid pavement design methodologies for military pavements," Technical Report GL-83-18, U.S. Army Engineer Waterways Experiment Station, Corps of Engineers, $66 \mathrm{pp}$.

Yeo, R. E. Y. and Auff, A. A. (1995). "Pavement construction variabilitylocal roads," Proceedings of the Second International Conference on Road and Airfield Pavement Technology, Center for Transportation Research, National University of Singapore, pp. 734-745.

Yoder, E. J. and Witczak, M. W. (1975). Principles of Pavement Design, second edition, John Wiley and Sons, Inc., New York, 711 pp. 
Appendix A

Statistical Reference Tables

Appendix A Statistical Reference Tables

Al 


\begin{tabular}{|c|c|c|c|c|c|c|c|c|c|c|}
\hline$z$ & .00 & .01 & .02 & .03 & .04 & .05 & .06 & .07 & .08 & .09 \\
\hline 0.0 & .5000 & .4960 & .4920 & .4880 & .4840 & .4801 & .4761 & .4721 & .4681 & .4641 \\
\hline 0.1 & .4602 & .4562 & 4522 & .4483 & .4443 & .4404 & .4364 & .4325 & .4286 & .4247 \\
\hline 0.2 & .4207 & .4168 & 4129 & .4090 & .4052 & .4013 & .3974 & .3936 & .3897 & .3859 \\
\hline 0.3 & .3821 & .3783 & .3745 & .3707 & .3669 & .3632 & .3594 & .3557 & .3520 & .3483 \\
\hline 0.4 & .3446 & .3409 & .3372 & .3336 & .3300 & .3264 & .3228 & .3192 & .3156 & .3121 \\
\hline 0.5 & .3085 & .3050 & .3015 & .2981 & .2946 & .2912 & .2877 & .2843 & .2810 & .2776 \\
\hline 0.6 & .2743 & .2709 & .2676 & .2643 & .2611 & .2578 & .2546 & .2514 & .2483 & .2451 \\
\hline 0.7 & .2420 & .2389 & .2358 & .2327 & .2296 & .2266 & .2236 & .2206 & .2177 & .2148 \\
\hline 0.8 & .2119 & .2090 & .2061 & .2033 & .2005 & .1977 & .1949 & .1922 & .1894 & .1867 \\
\hline 0.9 & .1841 & .1814 & .1788 & .1762 & .1736 & . 1711 & .1685 & .1660 & .1635 & .1611 \\
\hline 1.0 & .1587 & .1562 & .1539 & .1515 & .1492 & .1469 & .1446 & .1423 & .1401 & .1379 \\
\hline 1.1 & .1357 & .1335 & .1314 & .1292 & .1271 & .1251 & .1230 & .1210 & .1190 & .1170 \\
\hline 1.2 & .1151 & .1131 & .1112 & .1093 & .1075 & .1056 & .1038 & .1020 & .1003 & .0985 \\
\hline 1.3 & .0968 & .0951 & .0934 & .0918 & .0901 & .0885 & .0869 & .0853 & .0838 & .0823 \\
\hline 1.4 & .0808 & .0793 & .0078 & .0764 & .0749 & .0735 & .0721 & .0708 & .0694 & .0681 \\
\hline 1.5 & .0668 & .0655 & .0643 & .0630 & .0618 & .0606 & .0594 & .0582 & .0571 & .0559 \\
\hline 1.6 & .0548 & .0537 & .0526 & .0516 & .0505 & .0495 & .0485 & .0475 & .0465 & .0455 \\
\hline 1.7 & .0446 & .0436 & .0427 & .0418 & .0409 & .0401 & .0392 & .0384 & .0375 & .0367 \\
\hline 1.8 & .0359 & .0351 & .0344 & .0336 & .0329 & .0322 & .0314 & .0307 & .0301 & .0294 \\
\hline 1.9 & .0287 & .0281 & .0274 & .0268 & .0262 & .0256 & .0250 & .0244 & .0239 & .0233 \\
\hline 2.0 & .0228 & .0222 & .0217 & .0212 & .0207 & .0202 & .0197 & .0192 & .0188 & .0183 \\
\hline 2.1 & .0179 & .0174 & .0170 & .0166 & .0162 & .0158 & .0154 & .0150 & .0146 & .0143 \\
\hline 2.2 & .0139 & .0136 & .0132 & .0129 & .0125 & .0122 & .0119 & .0116 & .0113 & .0110 \\
\hline 2.3 & .0107 & .0104 & .0102 & .0099 & .0096 & .0094 & .0091 & .0089 & .0087 & .0084 \\
\hline 2.4 & .0082 & .0080 & .0078 & .0075 & .0073 & .0071 & .0069 & .0068 & .0066 & .0064 \\
\hline 2.5 & .0062 & .0060 & .0059 & .0057 & .0055 & .0054 & .0052 & .0051 & .0049 & .0048 \\
\hline 2.6 & .0047 & .0045 & .0044 & .0043 & .0041 & .0040 & .0039 & .0038 & .0037 & .0036 \\
\hline 2.7 & .0035 & .0034 & .0033 & .0032 & .0031 & .0030 & .0029 & .0028 & .0027 & .0026 \\
\hline 2.8 & .0026 & .0025 & .0024 & .0023 & .0023 & .0022 & .0021 & .0021 & .0020 & .0019 \\
\hline
\end{tabular}

(Continued) 


\begin{tabular}{||c|c|c|c|c|c|c|c|c|c|c||}
\hline \hline \multicolumn{10}{||c|}{ Table A1 (Concluded) } \\
\hline \hline$z$ & .00 & .01 & .02 & .03 & .04 & .05 & .06 & .07 & .08 & .09 \\
\hline 2.9 & .0019 & .0018 & .0018 & .0017 & .0016 & .0016 & .0015 & .0015 & .0014 & .0014 \\
\hline 3.0 & .0013 & .0013 & .0013 & .0012 & .0012 & .0011 & .0011 & .0011 & .0010 & .0010 \\
\hline 3.1 & .0010 & .0009 & .0009 & .0009 & .0008 & .0008 & .0008 & .0008 & .0007 & .0007 \\
\hline 3.2 & .0007 & .0007 & .0006 & .0006 & .0006 & .0006 & .0006 & .0005 & .0005 & .0005 \\
\hline 3.3 & .0005 & .0005 & .0005 & .0004 & .0004 & .0004 & .0004 & .0004 & .0004 & .0003 \\
\hline 3.4 & .0003 & .0003 & .0003 & .0003 & .0003 & .0003 & .0003 & .0003 & .0003 & .0002 \\
\hline 3.6 & .0002 & .0002 & .0001 & .0001 & .0001 & .0001 & .0001 & .0001 & .0001 & .0001 \\
\hline \hline
\end{tabular}




\begin{tabular}{|c|c|c|c|c|c|}
\hline \multicolumn{6}{|c|}{$\begin{array}{l}\text { Table A2 } \\
\text { Values of } t \text { (after Fisher and Yates 1949) }\end{array}$} \\
\hline \multirow[b]{2}{*}{ df } & \multicolumn{5}{|c|}{ Probability of a Numerically Larger Value of $t$ (Two-Tail Test) } \\
\hline & 0.1 & 0.05 & 0.02 & 0.01 & 0.001 \\
\hline 1 & 6.314 & 12.706 & 31.821 & 63.657 & 636.619 \\
\hline 2 & 2.920 & 4.303 & 6.965 & 9.925 & 31.598 \\
\hline 3 & 2.353 & 3.182 & 4.541 & 5.841 & 12.941 \\
\hline 4 & 2.132 & 2.776 & 3.747 & 4.604 & 8.610 \\
\hline 5 & 2.015 & 2.571 & 3.365 & 4.032 & 6.859 \\
\hline 6 & 1.943 & 2.447 & 3.143 & 3.707 & 5.959 \\
\hline 7 & 1.895 & 2.365 & 2.998 & 3.499 & 5.405 \\
\hline 8 & 1.860 & 2.306 & 2.896 & 3.355 & 5.041 \\
\hline 9 & 1.833 & 2.262 & 2.821 & 3.250 & 4.781 \\
\hline 10 & 1.812 & 2.228 & 2.764 & 3.169 & 4.587 \\
\hline 11 & 1.796 & 2.201 & 2.718 & 3.106 & 4.437 \\
\hline 12 & 1.782 & 2.179 & 2.681 & 3.055 & 4.318 \\
\hline 13 & 1.771 & 2.160 & 2.650 & 3.012 & 4.221 \\
\hline 14 & 1.761 & 2.145 & 2.624 & 2.977 & 4.140 \\
\hline 15 & 1.753 & 2.131 & 2.602 & 2.947 & 4.073 \\
\hline 16 & 1.746 & 2.120 & 2.583 & 2.921 & 4.015 \\
\hline 17 & 1.740 & 2.110 & 2.567 & 2.898 & 3.965 \\
\hline 18 & 1.734 & 2.101 & 2.552 & 2.878 & 3.922 \\
\hline 19 & 1.729 & 2.093 & 2.539 & 2.861 & 3.883 \\
\hline 20 & 1.725 & 2.086 & 2.528 & 2.845 & 3.850 \\
\hline \multirow[t]{2}{*}{ df } & 0.05 & 0.025 & 0.01 & 0.005 & 0.0005 \\
\hline & \multicolumn{5}{|c|}{ Probability of a Larger Positive Value of $t$ (One-Tail Test) } \\
\hline
\end{tabular}




\begin{tabular}{|c|c|c|c|c|c|}
\hline \multirow[b]{2}{*}{ df } & \multicolumn{5}{|c|}{ Probability of a Numerically Larger Value of $t$ (Two-Tail Test) } \\
\hline & 0.1 & 0.05 & 0.02 & 0.01 & 0.001 \\
\hline 21 & 1.721 & 2.080 & 2.518 & 2.831 & 3.819 \\
\hline 22 & 1.717 & 2.074 & 2.508 & 2.819 & 3.792 \\
\hline 23 & 1.714 & 2.069 & 2.500 & 2.807 & 3.767 \\
\hline 24 & 1.711 & 2.064 & 2.492 & 2.797 & 3.745 \\
\hline 25 & 1.708 & 2.060 & 2.485 & 2.787 & 3.725 \\
\hline 26 & 1.706 & 2.056 & 2.479 & 2.779 & 3.707 \\
\hline 27 & 1.703 & 2.052 & 2.473 & 2.771 & 3.690 \\
\hline 28 & 1.701 & 2.048 & 2.467 & 2.763 & 3.674 \\
\hline 29 & 1.699 & 2.045 & 2.462 & 2.756 & 3.659 \\
\hline 30 & 1.697 & 2.042 & 2.457 & 2.750 & 3.646 \\
\hline 40 & 1.684 & 2.021 & 2.423 & 2.704 & 3.551 \\
\hline 60 & 1.671 & 2.000 & 2.390 & 2.660 & 3.460 \\
\hline 120 & 1.658 & 1.980 & 2.358 & 2.617 & 3.373 \\
\hline$\infty$ & 1.645 & 1.960 & 2.326 & 2.576 & 3.291 \\
\hline \multirow[t]{2}{*}{ df } & 0.05 & 0.025 & 0.01 & 0.005 & 0.0005 \\
\hline & \multicolumn{5}{|c|}{ Probability of a Larger Positive Value of $t$ (One-Tail Test) } \\
\hline
\end{tabular}




\section{Table A3}

Values of $X^{2}$ (after Thompson 1941)

\begin{tabular}{|c|c|c|c|c|c|c|c|c|c|c|c|}
\hline \multirow[b]{2}{*}{ df } & \multicolumn{11}{|c|}{ Probability of Obtaining a Larger Value of $x^{2}$} \\
\hline & .990 & .975 & .950 & .900 & .750 & .500 & .250 & .100 & .050 & .025 & .010 \\
\hline 1 & $<.0001$ & $<.0001$ & .0004 & .0158 & .102 & .455 & 1.32 & 2.71 & 3.84 & 5.02 & 6.63 \\
\hline 2 & .0201 & .0506 & .103 & .211 & .575 & 1.39 & 2.77 & 4.61 & 5.99 & 7.38 & 9.21 \\
\hline 3 & .115 & .216 & .352 & .584 & 1.21 & 2.37 & 4.11 & 6.25 & 7.81 & 9.35 & 11.3 \\
\hline 4 & .297 & .484 & .711 & 1.06 & 1.92 & 3.36 & 5.39 & 7.78 & 9.49 & 11.1 & 13.3 \\
\hline 5 & .554 & .831 & 1.15 & 1.61 & 2.67 & 4.35 & 6.63 & 9.24 & 11.1 & 12.8 & 15.1 \\
\hline 6 & .872 & 1.24 & 1.64 & 2.20 & 3.45 & 5.35 & 7.84 & 10.6 & 12.6 & 14.4 & 16.8 \\
\hline 7 & 1.24 & 1.69 & 2.17 & 2.83 & 4.25 & 6.35 & 9.04 & 12.0 & 14.1 & 16.0 & 18.5 \\
\hline 8 & 1.65 & 2.18 & 2.73 & 3.49 & 5.07 & 7.34 & 10.2 & 13.4 & 15.5 & 17.5 & 20.1 \\
\hline 9 & 2.09 & 2.70 & 3.33 & 4.17 & 5.90 & 8.34 & 11.4 & 14.7 & 16.9 & 19.0 & 21.7 \\
\hline 10 & 2.56 & 3.25 & 3.94 & 4.87 & 6.74 & 9.34 & 12.5 & 16.0 & 18.3 & 20.5 & 23.2 \\
\hline 11 & 3.05 & 3.82 & 4.57 & 5.58 & 7.58 & 10.3 & 13.7 & 17.3 & 19.7 & 21.9 & 24.7 \\
\hline 12 & 3.57 & 4.40 & 5.23 & 6.30 & 8.44 & 11.3 & 14.8 & 18.5 & 21.0 & 23.3 & 26.2 \\
\hline 13 & 4.11 & 5.01 & 5.89 & 7.04 & 9.30 & 12.3 & 16.0 & 19.8 & 22.4 & 24.7 & 27.7 \\
\hline 14 & 4.66 & 5.63 & 6.57 & 7.79 & 10.2 & 13.3 & 17.1 & 21.1 & 23.7 & 26.1 & 29.1 \\
\hline 15 & 5.23 & 6.26 & 7.26 & 8.55 & 11.0 & 14.3 & 18.2 & 22.3 & 25.0 & 27.5 & 30.6 \\
\hline 16 & 5.81 & 6.91 & 7.96 & 9.31 & 11.9 & 15.3 & 19.4 & 23.5 & 26.3 & 28.8 & 32.0 \\
\hline 17 & 6.41 & 7.56 & 8.67 & 10.1 & 12.8 & 16.3 & 20.5 & 24.8 & 27.6 & 30.2 & 33.4 \\
\hline
\end{tabular}




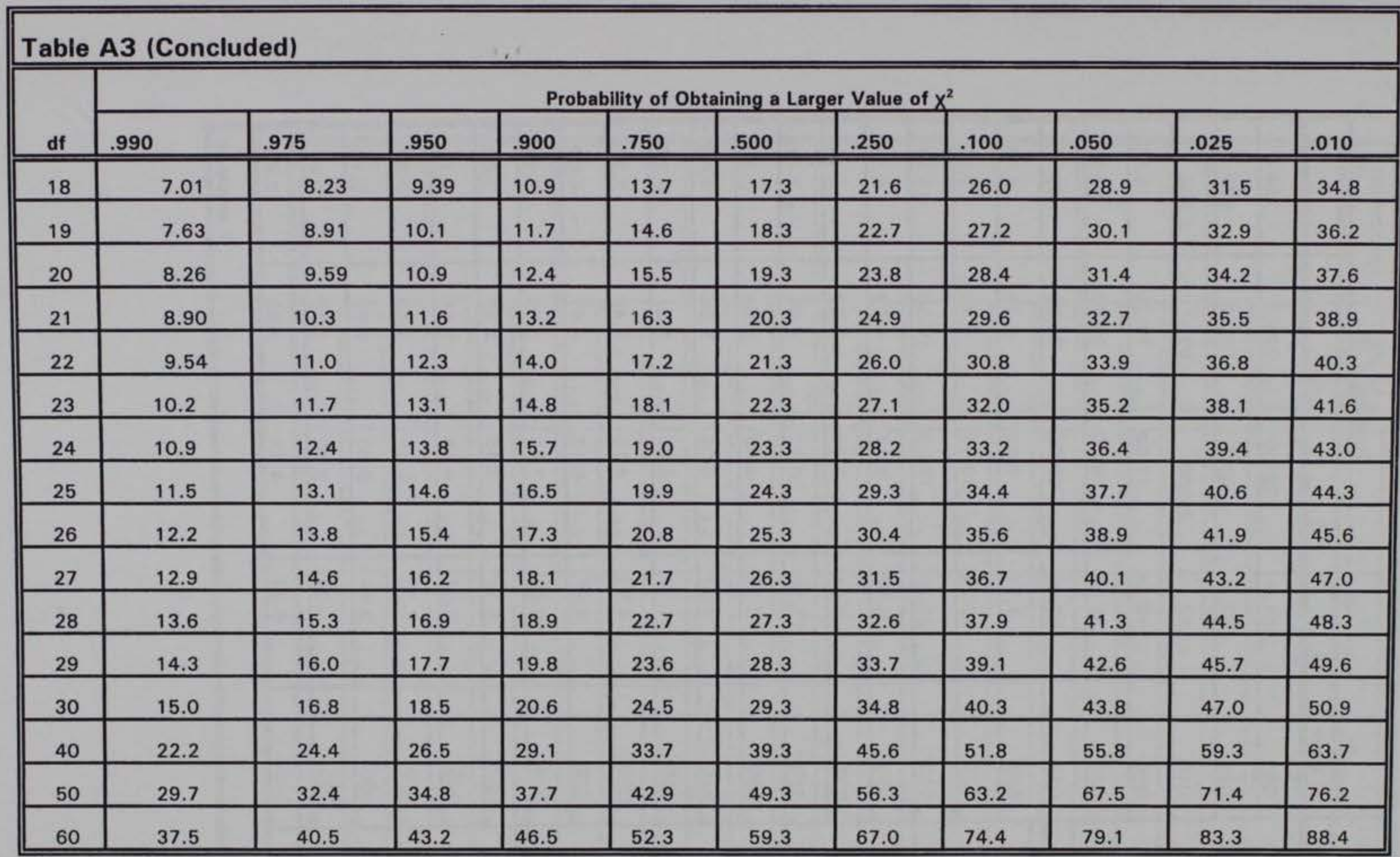




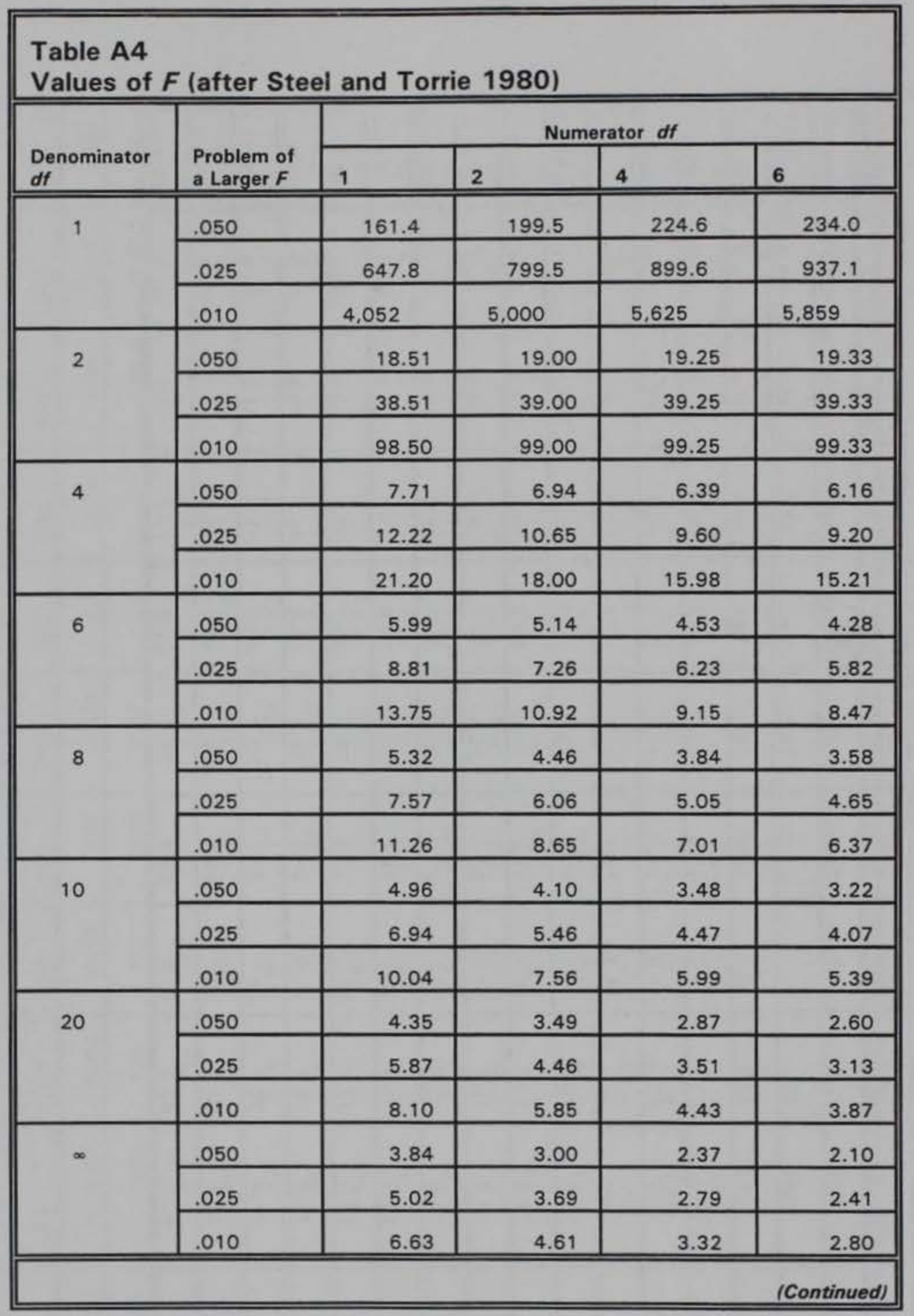




\begin{tabular}{|c|c|c|c|c|c|}
\hline \multirow{2}{*}{$\begin{array}{l}\text { Denominator } \\
\text { df } \\
\end{array}$} & \multirow{2}{*}{$\begin{array}{l}\text { Prob, of a } \\
\text { Larger } F\end{array}$} & \multicolumn{4}{|c|}{ Numerator $d f$} \\
\hline & & 8 & 10 & 20 & $\infty$ \\
\hline \multirow[t]{3}{*}{1} & .050 & 238.9 & 241.9 & 248.0 & 254.3 \\
\hline & .025 & 956.7 & 968.6 & 993.1 & 1018 \\
\hline & .010 & 5,982 & 6,056 & 6,209 & 6,366 \\
\hline \multirow[t]{3}{*}{2} & .050 & 19.37 & 19.40 & 19.45 & 19.50 \\
\hline & .025 & 39.37 & 39.40 & 39.45 & 39.50 \\
\hline & .010 & 99.37 & 99.40 & 99.45 & 99.50 \\
\hline \multirow[t]{3}{*}{4} & .050 & 6.04 & 5.96 & 5.80 & 5.63 \\
\hline & .025 & 8.98 & 8.84 & 8.56 & 8.26 \\
\hline & .010 & 14.80 & 14.55 & 14.02 & 13.46 \\
\hline \multirow[t]{3}{*}{6} & .050 & 4.15 & 4.06 & 3.87 & 3.67 \\
\hline & .025 & 5.60 & 5.46 & 5.17 & 4.85 \\
\hline & .010 & 8.10 & 7.87 & 7.40 & 6.88 \\
\hline \multirow[t]{3}{*}{8} & .050 & 3.44 & 3.35 & 3.15 & 2.93 \\
\hline & .025 & 4.43 & 4.30 & 4.00 & 3.67 \\
\hline & .010 & 6.03 & 5.81 & 5.36 & 4.86 \\
\hline \multirow[t]{3}{*}{10} & .050 & 3.07 & 2.98 & 2.77 & 2.54 \\
\hline & .025 & 3.85 & 3.72 & 3.42 & 3.08 \\
\hline & .010 & 5.06 & 4.85 & 4.41 & 3.91 \\
\hline \multirow[t]{3}{*}{20} & .050 & 2.45 & 2.35 & 2.12 & 1.84 \\
\hline & .025 & 2.91 & 2.77 & 2.46 & 2.09 \\
\hline & .010 & 3.56 & 3.37 & 2.94 & 2.42 \\
\hline \multirow[t]{3}{*}{$\infty$} & .050 & 1.94 & 1.83 & 1.57 & 1.00 \\
\hline & .025 & 2.19 & 2.05 & 1.71 & 1.00 \\
\hline & .010 & 2.51 & 2.32 & 1.88 & 1.00 \\
\hline
\end{tabular}




\begin{tabular}{|c|c|c|c|c|c|c|}
\hline \multicolumn{7}{|c|}{$\begin{array}{l}\text { Table A5 } \\
\text { Critical Values for T When Standard Deviation is Calculated from } \\
\text { the Sample [after ASTM (1995b) E 178] }\end{array}$} \\
\hline \multirow{2}{*}{$\begin{array}{l}\text { No. of } \\
\text { Observed }\end{array}$} & \multicolumn{6}{|c|}{ Significance Level (One-Sided Test) } \\
\hline & $0.1 \%$ & $0.5 \%$ & $1.0 \%$ & $2.5 \%$ & $5 \%$ & $10 \%$ \\
\hline 3 & 1.155 & 1.155 & 1.155 & 1.155 & 1.153 & 1.148 \\
\hline 4 & 1.499 & 1.496 & 1.492 & 1.481 & 1.463 & 1.425 \\
\hline 5 & 1.780 & 1.764 & 1.749 & 1.715 & 1.672 & 1.602 \\
\hline 6 & 2.011 & 1.973 & 1.944 & 1.887 & 1.822 & 1.729 \\
\hline 7 & 2.201 & 2.139 & 2.097 & 2.020 & 1.938 & 1.828 \\
\hline 8 & 2.358 & 2.274 & 2.221 & 2.126 & 2.032 & 1.909 \\
\hline 9 & 2.492 & 2.387 & 2.323 & 2.215 & 2.110 & 1.977 \\
\hline 10 & 2.606 & 2.482 & 2.410 & 2.290 & 2.176 & 2.036 \\
\hline 15 & 2.997 & 2.806 & 2.705 & 2.549 & 2.409 & 2.247 \\
\hline 20 & 3.230 & 3.001 & 2.884 & 2.709 & 2.557 & 2.385 \\
\hline 25 & 3.389 & 3.135 & 3.009 & 2.822 & 2.663 & 2.486 \\
\hline 30 & 3.507 & 3.236 & 3.103 & 2.908 & 2.745 & 2.563 \\
\hline 40 & 3.673 & 3.381 & 3.240 & 3.036 & 2.866 & 2.682 \\
\hline 50 & 3.789 & 3.483 & 3.336 & 3.128 & 2.956 & 2.768 \\
\hline 60 & 3.874 & 3.560 & 3.411 & 3.199 & 3.025 & 2.837 \\
\hline 70 & 3.942 & 3.622 & 3.471 & 3.257 & 3.082 & 2.893 \\
\hline 80 & 3.998 & 3.673 & 3.521 & 3.305 & 3.130 & 2.940 \\
\hline 90 & 3.998 & 3.673 & 3.521 & 3.305 & 3.130 & 2.940 \\
\hline 100 & 4.084 & 3.754 & 3.600 & 3.383 & 3.207 & 3.017 \\
\hline 110 & 4.044 & 3.716 & 3.563 & 3.347 & 3.171 & 2.981 \\
\hline 120 & 4.150 & 3.817 & 3.662 & 3.444 & 3.267 & 3.078 \\
\hline 130 & 4.178 & 3.843 & 3.688 & 3.470 & 3.294 & 3.104 \\
\hline 140 & 4.203 & 3.867 & 3.712 & 3.493 & 3.318 & 3.129 \\
\hline
\end{tabular}




\section{Table A6}

Tietjen-Moore Critical Values (x1000) for $E_{k}$ [after ASTM (1995b) E 178]

\begin{tabular}{|c|c|c|c|c|c|c|c|c|c|c|c|c|c|c|}
\hline \multirow[b]{2}{*}{$k$} & \multirow[b]{2}{*}{$\alpha$} & \multicolumn{13}{|c|}{ Number of Values in Data Set } \\
\hline & & 50 & 40 & 30 & 20 & 15 & 10 & 9 & 8 & 7 & 6 & 5 & 4 & 3 \\
\hline \multirow[t]{3}{*}{1} & 0.01 & 748 & 704 & 624 & 499 & 404 & 235 & 197 & 156 & 110 & 68 & 29 & 4 & N/A \\
\hline & 0.05 & 796 & 756 & 698 & 594 & 503 & 353 & 310 & 262 & 207 & 145 & 81 & 25 & 1 \\
\hline & 0.10 & 820 & 784 & 730 & 638 & 556 & 415 & 374 & 326 & 270 & 203 & 127 & 49 & 3 \\
\hline \multirow[t]{3}{*}{2} & 0.01 & 636 & 574 & 482 & 339 & 238 & 101 & 78 & 50 & 28 & 12 & 2 & N/A & N/A \\
\hline & 0.05 & 684 & 629 & 549 & 416 & 317 & 172 & 137 & 99 & 65 & 34 & 10 & 1 & N/A \\
\hline & 0.10 & 708 & 657 & 582 & 460 & 360 & 214 & 175 & 137 & 94 & 56 & 22 & 2 & N/A \\
\hline \multirow[t]{3}{*}{3} & 0.01 & 550 & 480 & 386 & 236 & 146 & 44 & 26 & 14 & 6 & 1 & N/A & N/A & N/A \\
\hline & 0.05 & 599 & 534 & 443 & 302 & 206 & 83 & 57 & 34 & 16 & 4 & N/A & N/A & N/A \\
\hline & 0.10 & 622 & 562 & 475 & 338 & 240 & 108 & 80 & 53 & 27 & 9 & N/A & N/A & N/A \\
\hline \multirow[t]{3}{*}{4} & 0.01 & 482 & 408 & 308 & 170 & 90 & 18 & 9 & 4 & N/A & N/A & N/A & N/A & N/A \\
\hline & 0.05 & 529 & 458 & 364 & 221 & 134 & 37 & 21 & 10 & N/A & N/A & N/A & N/A & N/A \\
\hline & 0.10 & 552 & 486 & 391 & 252 & 160 & 52 & 32 & 16 & N/A & N/A & N/A & N/A & $\mathrm{N} / \mathrm{A}$ \\
\hline \multirow[t]{3}{*}{5} & 0.01 & 424 & 347 & 250 & 121 & 54 & 6 & N/A & N/A & N/A & N/A & N/A & N/A & N/A \\
\hline & 0.05 & 468 & 395 & 298 & 163 & 84 & 14 & N/A & N/A & N/A & N/A & N/A & N/A & N/A \\
\hline & 0.10 & 492 & 422 & 325 & 188 & 105 & 22 & N/A & N/A & N/A & N/A & N/A & N/A & N/A \\
\hline
\end{tabular}




\begin{tabular}{|c|c|c|c|c|c|c|}
\hline \multicolumn{7}{|c|}{$\begin{array}{l}\text { Table A7 } \\
\text { Values of } F_{\max } \text { (after Ott 1977) }\end{array}$} \\
\hline \multirow{2}{*}{$\begin{array}{l}d f \\
\text { each } \\
\text { sample } \\
\end{array}$} & \multirow{2}{*}{$\begin{array}{l}\text { Problem } \\
\text { of a } \\
\text { Larger } F_{m e r} \\
\end{array}$} & \multicolumn{5}{|c|}{ Number of Independent Mean Squares } \\
\hline & & $\underline{2}$ & 3 & 4 & 5 & 6 \\
\hline \multirow[t]{2}{*}{2} & .050 & 39.0 & 87.5 & 142 & 202 & 266 \\
\hline & .010 & 199 & 448 & 729 & 1,036 & 1,362 \\
\hline \multirow[t]{2}{*}{3} & .050 & 15.4 & 27.8 & 39.2 & 50.7 & 62.0 \\
\hline & .010 & 47.5 & 85 & 120 & 151 & 184 \\
\hline \multirow[t]{2}{*}{4} & .050 & 9.60 & 15.5 & 20.6 & 26.2 & 29.5 \\
\hline & .010 & 23.2 & 37 & 49 & 59 & 69 \\
\hline \multirow[t]{2}{*}{5} & .050 & 7.15 & 10.3 & 13.7 & 16.3 & 18.7 \\
\hline & .010 & 14.9 & 22 & 28 & 33 & 38 \\
\hline \multirow[t]{2}{*}{6} & .050 & 5.82 & 8.38 & 10.4 & 12.1 & 13.7 \\
\hline & .010 & 11.1 & 15.5 & 19.1 & 22 & 25 \\
\hline \multirow[t]{2}{*}{7} & .050 & 4.99 & 6.94 & 8.44 & 9.70 & 10.8 \\
\hline & .010 & 8.89 & 12.1 & 14.5 & 16.5 & 18.4 \\
\hline \multirow[t]{2}{*}{8} & .050 & 4.43 & 6.00 & 7.18 & 8.12 & 9.03 \\
\hline & .010 & 7.50 & 9.9 & 11.7 & 13.2 & 14.5 \\
\hline \multirow[t]{2}{*}{9} & .050 & 4.03 & 5.34 & 6.31 & 7.11 & 7.80 \\
\hline & .010 & 6.54 & 8.5 & 9.9 & 11.1 & 12.1 \\
\hline \multirow[t]{2}{*}{10} & .050 & 3.72 & 4.85 & 5.67 & 6.34 & 6.92 \\
\hline & .010 & 5.85 & 7.4 & 8.6 & 9.6 & 10.4 \\
\hline \multirow[t]{2}{*}{12} & .050 & 3.28 & 4.16 & 4.79 & 5.30 & 5.72 \\
\hline & .010 & 4.91 & 6.1 & 6.9 & 7.6 & 8.2 \\
\hline \multirow[t]{2}{*}{15} & .050 & 2.86 & 3.54 & 4.01 & 4.37 & 4.68 \\
\hline & .010 & 4.07 & 4.9 & 5.5 & 6.0 & 6.4 \\
\hline \multirow[t]{2}{*}{30} & .050 & 2.07 & 2.40 & 2.61 & 2.78 & 2.91 \\
\hline & .010 & 2.63 & 3.0 & 3.3 & 3.4 & 3.6 \\
\hline \multirow[t]{2}{*}{$\infty$} & .050 & 1.00 & 1.00 & 1.00 & 1.00 & 1.00 \\
\hline & .010 & 1.00 & 1.00 & 1.00 & 1.00 & 1.00 \\
\hline
\end{tabular}




\begin{tabular}{|c|c|c|c|c|c|c|}
\hline \multirow{2}{*}{$\begin{array}{l}d f \\
\text { each } \\
\text { sample } \\
\end{array}$} & \multirow{2}{*}{$\begin{array}{l}\text { Problem } \\
\text { of a } \\
\text { Larger } F_{\mathrm{ma}} \\
\end{array}$} & \multicolumn{5}{|c|}{ Number of Independent Mean Squares } \\
\hline & & 7 & 8 & 10 & 12 & 15 \\
\hline \multirow[t]{2}{*}{2} & .050 & 333 & 403 & 550 & 704 & 968 \\
\hline & .010 & 1,705 & 2,063 & 2,813 & 3,605 & 4,873 \\
\hline \multirow[t]{2}{*}{3} & .050 & 72.9 & 83.5 & 104 & 124 & 151 \\
\hline & .010 & 216 & 249 & 310 & 361 & 418 \\
\hline \multirow[t]{2}{*}{4} & .050 & 33.6 & 37.5 & 44.6 & 51.4 & 58.1 \\
\hline & .010 & 79 & 89 & 106 & 120 & 137 \\
\hline \multirow[t]{2}{*}{5} & .050 & 20.8 & 22.9 & 26.5 & 29.9 & 32.6 \\
\hline & .010 & 42 & 46 & 54 & 60 & 66 \\
\hline \multirow[t]{2}{*}{6} & .050 & 15.0 & 16.3 & 18.6 & 20.7 & 22.1 \\
\hline & .010 & 27 & 30 & 34 & 37 & 39 \\
\hline \multirow[t]{2}{*}{7} & .050 & 11.8 & 12.7 & 14.3 & 15.8 & 16.6 \\
\hline & .010 & 20 & 22 & 24 & 27 & 32 \\
\hline \multirow[t]{2}{*}{8} & .050 & 9.8 & 10.5 & 11.7 & 12.7 & 13.1 \\
\hline & .010 & 15.8 & 16.9 & 18.9 & 21 & 24 \\
\hline \multirow[t]{2}{*}{9} & .050 & 8.41 & 8.95 & 9.91 & 10.7 & 10.9 \\
\hline & .010 & 13.1 & 13.9 & 15.3 & 16.6 & 18.2 \\
\hline \multirow[t]{2}{*}{10} & .050 & 7.42 & 7.87 & 8.66 & 9.34 & 9.45 \\
\hline & .010 & 11.1 & 11.8 & 12.9 & 13.9 & 15.1 \\
\hline \multirow[t]{2}{*}{12} & .050 & 6.09 & 6.42 & 7.00 & 7.48 & 8.03 \\
\hline & .010 & 8.7 & 9.1 & 9.9 & 10.6 & 11.6 \\
\hline \multirow[t]{2}{*}{15} & .050 & 4.95 & 5.19 & 5.59 & 5.93 & 6.31 \\
\hline & .010 & 6.7 & 7.1 & 7.5 & 8.0 & 8.8 \\
\hline \multirow[t]{2}{*}{30} & .050 & 3.02 & 3.12 & 3.29 & 3.39 & 3.40 \\
\hline & .010 & 3.7 & 3.8 & 4.0 & 4.2 & 4.5 \\
\hline \multirow[t]{2}{*}{$\infty$} & .050 & 1.00 & 1.00 & 1.00 & 1.00 & 1.00 \\
\hline & .010 & 1.00 & 1.00 & 1.00 & 1.00 & 1.00 \\
\hline
\end{tabular}




\section{Appendix B Residual Fine-Grained Soil Deposits}




\begin{tabular}{|c|c|c|c|}
\hline \multicolumn{4}{|c|}{$\begin{array}{l}\text { Table B1 } \\
\text { Specific Gravity }\end{array}$} \\
\hline Mean & $\begin{array}{l}\text { Standard } \\
\text { Deviation }\end{array}$ & $\begin{array}{l}\text { Coefficient of } \\
\text { Variation, Percent }\end{array}$ & Reference \\
\hline 2.86 & 0.03 & 1.0 & Schultze (1972)' \\
\hline N/A & N/A & 2.0 & Padilla and Vanmarcke (1974) \\
\hline
\end{tabular}

\begin{tabular}{|c|c|c|c|}
\hline \multicolumn{4}{|c|}{$\begin{array}{l}\text { Table B2 } \\
\text { Natural Water Content, Percent }\end{array}$} \\
\hline Mean & $\begin{array}{l}\text { Standard } \\
\text { Deviation } \\
\end{array}$ & $\begin{array}{l}\text { Coefficient of } \\
\text { Variation, Percent }\end{array}$ & Reference \\
\hline 14 & 3.5 & 26 & Krahn and Fredlund (1983) \\
\hline 21 & 4.7 & 23 & \multirow[t]{2}{*}{ Schultze $(1972)^{1}$} \\
\hline 22 & 2.8 & 13 & \\
\hline 27 & 6.0 & 22 & Fredlund and Dahlman $(1972)^{2}$ \\
\hline 29 & 5.8 & 20 & Krahn and Fredlund (1983) \\
\hline 29 & 5.1 & 18 & Fredlund and Dahiman (1972) \\
\hline 32 & 4.4 & 14 & Krahn and Fredlund (1983) \\
\hline 33 & 4.1 & 12 & \multirow[t]{4}{*}{ Fredlund and Dahiman $(1972)^{2}$} \\
\hline 35 & 3.5 & 10 & \\
\hline 35 & 4.6 & 13 & \\
\hline 36 & 4.3 & 12 & \\
\hline
\end{tabular}




\begin{tabular}{|c|c|c|c|}
\hline \multicolumn{4}{|c|}{$\begin{array}{r}\text { Table B3 } \\
\text { Porosity } \\
\end{array}$} \\
\hline Mean & $\begin{array}{l}\text { Standard } \\
\text { Deviation } \\
\end{array}$ & $\begin{array}{l}\text { Coefficient of } \\
\text { Variation, Percent }\end{array}$ & Reference \\
\hline 0.33 & 0.06 & 19 & \multirow[t]{5}{*}{ (Schultze 1972)' } \\
\hline 0.38 & 0.05 & 13 & \\
\hline 0.39 & 0.04 & 10 & \\
\hline 0.40 & 0.03 & 7.5 & \\
\hline 0.48 & 0.05 & 10 & \\
\hline
\end{tabular}

\begin{tabular}{|c|c|c|c|}
\hline \multicolumn{4}{|c|}{$\begin{array}{l}\text { Table B4 } \\
\text { Void Ratio }\end{array}$} \\
\hline Mean & $\begin{array}{l}\text { Standard } \\
\text { Deviation } \\
\end{array}$ & $\begin{array}{l}\text { Coefficient of } \\
\text { Variation, Percent }\end{array}$ & Reference \\
\hline 0.42 & 0.09 & 21 & (Krahn and Fredlund 1983) \\
\hline 0.51 & 0.09 & 18 & \multirow[t]{5}{*}{ (Schultze 1972)' } \\
\hline 0.53 & 0.14 & 26 & \\
\hline 0.56 & 0.17 & 30 & \\
\hline 0.57 & 0.10 & 17 & \\
\hline 0.66 & 0.09 & 14 & \\
\hline 0.75 & 0.24 & 32 & \multirow[t]{4}{*}{ (Fredlund and Dahlman 1972) } \\
\hline 0.90 & 0.16 & 18 & \\
\hline 0.91 & 0.14 & 15 & \\
\hline 0.91 & 0.19 & 20 & \\
\hline 0.95 & 0.13 & 14 & (Krahn and Fredlund 1983) \\
\hline
\end{tabular}




\begin{tabular}{|c|c|c|c|}
\hline \multicolumn{4}{|c|}{$\begin{array}{l}\text { Table B5 } \\
\text { Degree of Saturation, Percent }\end{array}$} \\
\hline Mean & $\begin{array}{l}\text { Standard } \\
\text { Deviation } \\
\end{array}$ & $\begin{array}{l}\text { Coefficient of } \\
\text { Variation, Percent }\end{array}$ & Reference \\
\hline 78.7 & 11.4 & 15 & \multirow[t]{2}{*}{ Krahn and Fredlund (1983) } \\
\hline 81.3 & 10.6 & 13 & \\
\hline 85 & 16 & 19 & Schultze $(1972)^{1}$ \\
\hline 91.5 & 6.0 & 6.6 & Krahn and Fredlund (1983) \\
\hline 91.9 & 12.1 & 13 & \multirow[t]{2}{*}{ Fredlund and Dahlman (1972) } \\
\hline 93.3 & 8.0 & 8.5 & \\
\hline 94.1 & 10.0 & 11 & Krahn and Fredlund (1983) \\
\hline 95.6 & 8.6 & 9.0 & \multirow[t]{2}{*}{ Fredlund and Dahlman (1972) } \\
\hline 97.5 & 8.4 & 8.6 & \\
\hline
\end{tabular}

\begin{tabular}{||l|l|l|l||}
\hline \multicolumn{2}{||l||}{$\begin{array}{l}\text { Table B6 } \\
\text { Dry Density, } \mathbf{~ g g / m}\end{array}$} \\
\hline \hline Mean & $\begin{array}{l}\text { Standard } \\
\text { Deviation }\end{array}$ & $\begin{array}{l}\text { Coefficient of } \\
\text { Variation, Percent }\end{array}$ & Reference \\
\hline \hline 1,430 & 99 & 6.9 & \multirow{2}{*}{ (Krahn and Fredlund 1983) } \\
\hline 1,880 & 106 & 5.6 & \\
\hline
\end{tabular}

\begin{tabular}{|c|c|c|c|c|}
\hline \multicolumn{5}{|c|}{$\begin{array}{l}\text { Table B7 } \\
\text { Coefficient of Permeability, Percent }\end{array}$} \\
\hline Mean & $\begin{array}{l}\text { Standard } \\
\text { Deviation } \\
\end{array}$ & $\begin{array}{l}\text { Coefficient of } \\
\text { Variation, Percent }\end{array}$ & Comment & Reference \\
\hline N/A & N/A & 90 & 80 percent saturated & \multirow{2}{*}{$\begin{array}{l}\text { Nielson et al. } \\
(1973)\end{array}$} \\
\hline N/A & N/A & 700 & 100 percent saturated & \\
\hline
\end{tabular}




\begin{tabular}{|c|c|c|c|}
\hline \multicolumn{4}{|c|}{$\begin{array}{l}\text { Table B8 } \\
\text { Liquid Limit, Percent } \\
\end{array}$} \\
\hline Mean & $\begin{array}{l}\text { Standard } \\
\text { Deviation } \\
\end{array}$ & $\begin{array}{l}\text { Coefficient of } \\
\text { Variation, Percent } \\
\end{array}$ & Reference \\
\hline 16 & 9.7 & 62 & Mitchell et al. (1977) \\
\hline 20 & 4.0 & 20 & \multirow[t]{2}{*}{ Kennedy, Hudson, and McCullough (1975) } \\
\hline 27 & 5.4 & 20 & \\
\hline 27 & 6.0 & 22 & Krahn and Fredlund (1983) \\
\hline 33 & 6.3 & 19 & Kennedy, Hudson, and McCullough (1975) \\
\hline 43 & 11 & 26 & Wahls and Futrell (1966) \\
\hline 53 & 11 & 21 & Fredlund and Dahiman $(1972)^{\prime}$ \\
\hline 55 & 12 & 22 & Schultze $(1972)^{2}$ \\
\hline 57 & 13 & 24 & Krahn and Fredlund (1983) \\
\hline 59 & 13 & 22 & Fredlund and Dahiman $(1972)^{1}$ \\
\hline 62 & 12 & 19 & Krahn and Fredlund (1983) \\
\hline 63 & 14 & 22 & Wahis and Futrell (1966) \\
\hline 63 & 11 & 18 & \multirow[t]{2}{*}{ Fredlund and Dahlman (1972)' } \\
\hline 64 & 11 & 17 & \\
\hline 73 & 13 & 18 & Krahn and Fredlund (1983) \\
\hline $\begin{array}{l}\text { Frequ } \\
\text { Norm } \\
\text { Note: } \\
40 \text { perc }\end{array}$ & $\begin{array}{l}\text { y distribu } \\
\text { was not } \\
\text { pling erro }\end{array}$ & $\begin{array}{l}\text { ajs appeared normal } \\
\text { and experimental errc } \\
\text { variance (Hampton, }\end{array}$ & $\begin{array}{l}\text { shape. } \\
\text { e "goodness-of-fit" test. } \\
\text { testing and inherent) accounted for } \\
\text { der, and Burr 1962). }\end{array}$ \\
\hline
\end{tabular}




\begin{tabular}{|c|c|c|c|}
\hline \multicolumn{4}{|c|}{$\begin{array}{l}\text { Table B9 } \\
\text { Plastic Limit, Percent }\end{array}$} \\
\hline Mean & $\begin{array}{l}\text { Standard } \\
\text { Deviation } \\
\end{array}$ & $\begin{array}{l}\text { Coefficient of } \\
\text { Variation, Percent } \\
\end{array}$ & Reference \\
\hline 14 & 2.2 & 16 & Krahn and Fredlund (1983) \\
\hline 21 & 3.4 & 16 & Schultze $(1972)^{\prime}$ \\
\hline 23 & 3.8 & 17 & Krahn and Fredlund (1983) \\
\hline 24 & 3.2 & 13 & \multirow[t]{3}{*}{ Fredlund and Dahlman $(1972)^{2}$} \\
\hline 25 & 3.8 & 15 & \\
\hline 25 & 3.2 & 13 & \\
\hline 25 & 3.4 & 13 & Krahn and Fredlund (1983) \\
\hline 26 & 3.4 & 13 & Fredlund and Dahiman $(1972)^{2}$ \\
\hline 27 & 4.8 & 19 & Krahn and Fredlund (1983) \\
\hline \multicolumn{4}{|c|}{$\begin{array}{l}\text { Normality was rejected by the chi square "goodness-of-fit" test. } \\
2 \text { Frequency distributions appeared normal in shape. } \\
\text { Note: Sampling error and experimental error (testing and inherent) accounted for } \\
35 \text { percent of the total variance (Hampton, Yoder, and Burr 1962). }\end{array}$} \\
\hline
\end{tabular}

\begin{tabular}{|c|c|c|c|}
\hline \multicolumn{4}{|c|}{$\begin{array}{l}\text { Table B10 } \\
\text { Plasticity Index, Percent }\end{array}$} \\
\hline Mean & $\begin{array}{l}\text { Standard } \\
\text { Deviation } \\
\end{array}$ & $\begin{array}{l}\text { Coefficient of } \\
\text { Variation, Percent } \\
\end{array}$ & Reference \\
\hline 4.3 & 3.4 & 80 & Mitchell et al. (1977) \\
\hline 10 & 4.8 & 48 & $\begin{array}{l}\text { Kennedy, Hudson, and } \\
\text { McCullough (1975) }\end{array}$ \\
\hline 12 & 7.2 & 59 & Wahls and Futrell (1966) \\
\hline 14 & 5.9 & 42 & \multirow{2}{*}{$\begin{array}{l}\text { Kennedy, Hudson, and } \\
\text { McCullough (1975) }\end{array}$} \\
\hline 16 & 2.6 & 16 & \\
\hline 27 & 10.2 & 39 & Wahls and Futrell (1966) \\
\hline 33.9 & 9.6 & 28 & Schultze $(1972)^{1}$ \\
\hline \multicolumn{4}{|c|}{$\begin{array}{l}\text { Normality was rejected by the chi square "goodness-of-fit" test. } \\
\text { Notes: (1) Frequency distributions appeared normal in shape (Ingles 1972). } \\
\text { (2) Sampling error and experimental error (testing and inherent) accounted for } \\
60 \text { percent of the total variance (Hampton, Yoder, and Burr 1962). }\end{array}$} \\
\hline
\end{tabular}




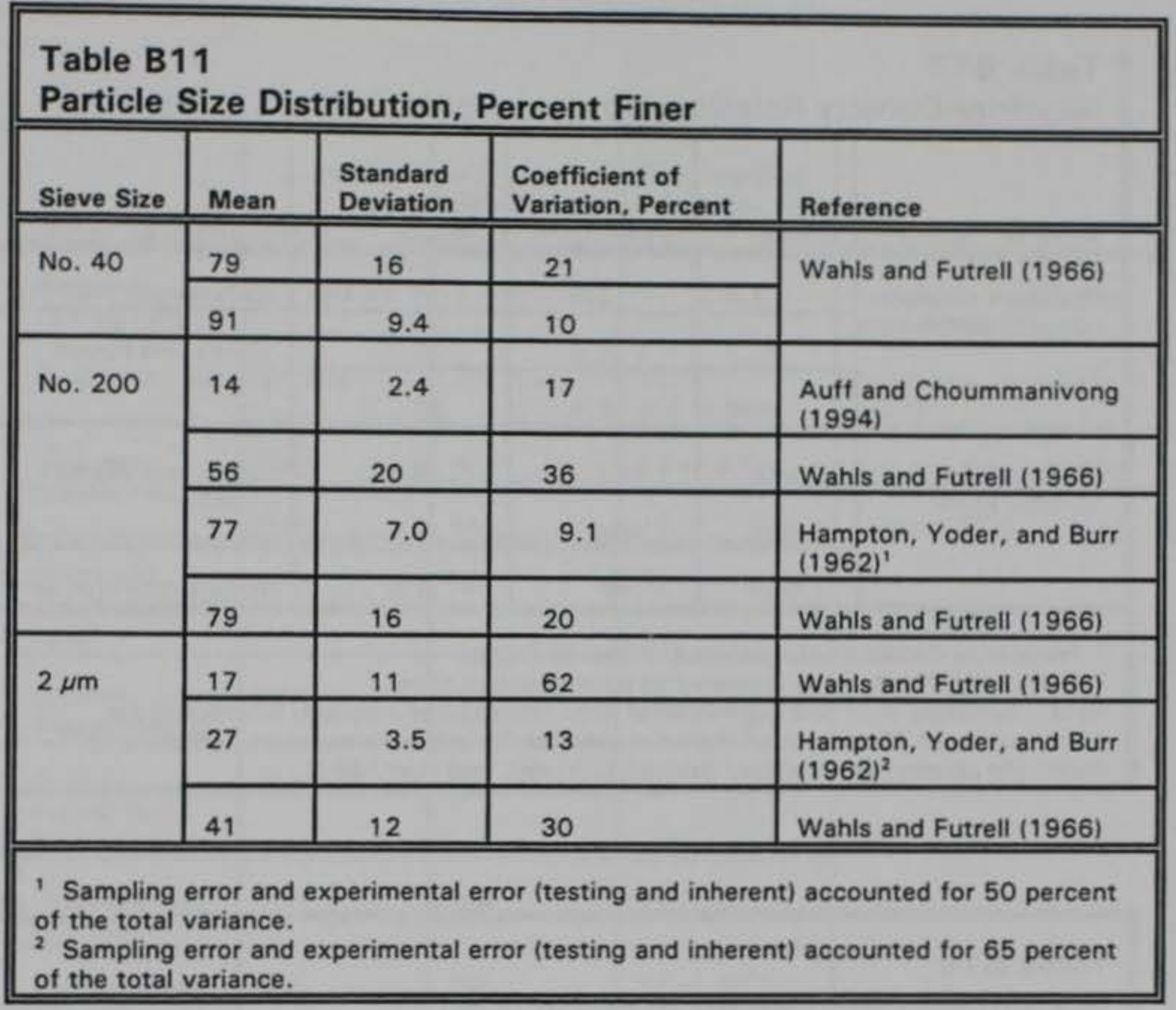

\begin{tabular}{|c|c|c|c|c|}
\hline \multicolumn{5}{|c|}{$\begin{array}{l}\text { Table B12 } \\
\text { Potential for Volume Change } \\
\end{array}$} \\
\hline Measure & Mean & $\begin{array}{l}\text { Standard } \\
\text { Deviation } \\
\end{array}$ & $\begin{array}{l}\text { Coefficient of } \\
\text { Variation, Percent } \\
\end{array}$ & Reference \\
\hline \multirow[t]{8}{*}{$\begin{array}{l}\text { Compression } \\
\text { index }\end{array}$} & 0.108 & 0.032 & 30 & $\begin{array}{l}\text { Krahn and Fredlund } \\
(1983)\end{array}$ \\
\hline & 0.110 & 0.052 & 47 & $\begin{array}{l}\text { Fredlund and Dahlman } \\
(1972)\end{array}$ \\
\hline & 0.155 & 0.049 & 33 & $\begin{array}{l}\text { Krahn and Fredlund } \\
\text { (1983) }\end{array}$ \\
\hline & 0.159 & 0.048 & 30 & \multirow{3}{*}{$\begin{array}{l}\text { Fredlund and Dahlman } \\
\text { (1972) }\end{array}$} \\
\hline & 0.167 & 0.048 & 29 & \\
\hline & 0.184 & 0.047 & 26 & \\
\hline & 0.205 & 0.066 & 32 & \multirow{2}{*}{$\begin{array}{l}\text { Krahn and Fredlund } \\
\text { (1983) }\end{array}$} \\
\hline & 0.265 & 0.070 & 26 & \\
\hline \multirow[t]{4}{*}{ Swell index } & 0.032 & 0.017 & 53 & \multirow{4}{*}{$\begin{array}{l}\text { Fredlund and Dahiman } \\
(1972)\end{array}$} \\
\hline & 0.065 & 0.034 & 52 & \\
\hline & 0.065 & 0.020 & 31 & \\
\hline & 0.065 & 0.017 & 26 & \\
\hline
\end{tabular}




\begin{tabular}{|c|c|c|c|c|}
\hline \multicolumn{5}{|c|}{$\begin{array}{l}\text { Table B13 } \\
\text { Moisture-Density Relationship }\end{array}$} \\
\hline Measure & Mean & $\begin{array}{l}\text { Standard } \\
\text { Deviation } \\
\end{array}$ & $\begin{array}{l}\text { Coefficient of } \\
\text { Variation, } \\
\text { Percent }\end{array}$ & Reference \\
\hline \multirow{3}{*}{$\begin{array}{l}\text { Optimum moisture } \\
\text { content, percent }\end{array}$} & 19.8 & 3.5 & 18 & Willenbrock (1974) \\
\hline & 20.3 & 5.6 & 28 & \multirow{2}{*}{$\begin{array}{l}\text { Wahls and Futrell } \\
(1966)\end{array}$} \\
\hline & 26.4 & 5.4 & 20 & \\
\hline \multirow{3}{*}{$\begin{array}{l}\text { Maximum dry } \\
\text { density, } \mathrm{kg} / \mathrm{m}^{3}\end{array}$} & 1,495 & 132 & 8.8 & \multirow{2}{*}{$\begin{array}{l}\text { Wahis and Futrell } \\
\text { (1966) }\end{array}$} \\
\hline & 1,655 & 164 & 9.9 & \\
\hline & 1,690 & 98 & 5.8 & Willenbrock $(1974)^{2}$ \\
\hline \multicolumn{5}{|c|}{$\begin{array}{l}\text { Frequency distributions appeared normal in shape. } \\
\text { Frequency distributions appeared to have negative skew. } \\
\text { Note: Sampling error and experimental error (testing and inherent) accounted for } \\
40 \text { percent and } 25 \text { percent of the total variance for optimum moisture content and } \\
\text { maximum density, respectively (Hampton, Yoder, and Burr 1962). }\end{array}$} \\
\hline
\end{tabular}

\begin{tabular}{|c|c|c|c|}
\hline \multicolumn{4}{|c|}{$\begin{array}{l}\text { Table B14 } \\
\text { Unconfined Compressive Strength (kPa) }\end{array}$} \\
\hline Mean & $\begin{array}{l}\text { Standard } \\
\text { Deviation }\end{array}$ & $\begin{array}{l}\text { Coefficient of } \\
\text { Variation, Percent }\end{array}$ & Reference \\
\hline 21 & 7.0 & 33 & Ladd, Moe, and Gifford (1972) \\
\hline 26 & 14 & 53 & \multirow[t]{3}{*}{ Schultze $(1972)^{\prime}$} \\
\hline 40 & 21 & 52 & \\
\hline 58 & 23 & 39 & \\
\hline 125 & 59 & 48 & \multirow[t]{3}{*}{ Fredlund and Dahlman $(1972)^{2}$} \\
\hline 143 & 57 & 40 & \\
\hline 161 & 66 & 41 & \\
\hline 167 & 75 & 45 & Krahn and Fredlund (1983) \\
\hline 199 & 98 & 49 & Fredlund and Dahlman $(1972)^{2}$ \\
\hline 220 & 122 & 55 & \multirow[t]{2}{*}{ Krahn and Fredlund (1983) } \\
\hline 253 & 179 & 71 & \\
\hline 331 & 86 & 26 & Morse (1972) \\
\hline 370 & 188 & 51 & Krahn and Fredlund (1983) \\
\hline $\begin{array}{ll}1 & \text { Norn } \\
2 & \text { Freq } \\
\text { Note: }\end{array}$ & $\begin{array}{l}\text { rejected } \\
\text { cribution a }\end{array}$ & hi square "goodne & $\begin{array}{l}\text { of-fit" test. } \\
\text { ew. } \\
\text { (lngles 1972). }\end{array}$ \\
\hline
\end{tabular}




\begin{tabular}{|c|c|c|c|c|}
\hline \multicolumn{5}{|c|}{$\begin{array}{l}\text { Table B15 } \\
\text { Measures of Shear Strength }\end{array}$} \\
\hline Measure & Mean & $\begin{array}{l}\text { Standard } \\
\text { Deviation } \\
\end{array}$ & $\begin{array}{l}\text { Coefficient of } \\
\text { Variation, } \\
\text { Percent } \\
\end{array}$ & Reference \\
\hline $\begin{array}{l}\text { California } \\
\text { bearing ratio }\end{array}$ & 10 percent & 2.7 percent & 27 & $\begin{array}{l}\text { Hampton, Yoder, and } \\
\text { Burr }(1962)^{1} \\
\end{array}$ \\
\hline Field vane & $26 \mathrm{kPa}$ & $7.6 \mathrm{kPa}$ & $\begin{array}{l}29 \\
\text { (19 to } 35)\end{array}$ & $\begin{array}{l}\text { Ladd, Moe, and Gifford } \\
(1972)\end{array}$ \\
\hline \multirow{2}{*}{$\begin{array}{l}\text { Undrained } \\
\text { triaxial test, c }\end{array}$} & N/A & N/A & 17 to $43^{2}$ & Kay and Krizek (1972) \\
\hline & N/A & N/A & 19 & \multirow[t]{6}{*}{ Lumb (1972) } \\
\hline $\begin{array}{l}\text { Undrained } \\
\text { triaxial test, } \\
\tan \phi\end{array}$ & N/A & N/A & 22 & \\
\hline $\begin{array}{l}\text { Drained } \\
\text { triaxial test, } \mathrm{c}\end{array}$ & N/A & N/A & 14 & \\
\hline $\begin{array}{l}\text { Drained } \\
\text { triaxial test, } \\
\tan \phi\end{array}$ & N/A & N/A & 1.6 & \\
\hline $\begin{array}{l}\text { Drained shear } \\
\text { box test, } c\end{array}$ & N/A & N/A & 95 to $103^{3,4}$ & \\
\hline $\begin{array}{l}\text { Drained shear } \\
\text { box test, } \tan \phi\end{array}$ & N/A & N/A & 18 to $46^{3.5}$ & \\
\hline \multicolumn{5}{|c|}{$\begin{array}{l}\text { Sampling error and experimental error (testing and inherent) accounted for } 80 \text { percent of } \\
\text { the total variance. } \\
2 \text { Depends on sampling technique. } \\
\text { Depends on type of soil. } \\
\text { Sampling error and experimental error (testing and inherent) accounted for } 20 \text { to } \\
50 \text { percent of the total variance. } \\
5 \text { Sampling error and experimental error (testing and inherent) accounted for } 10 \text { to } \\
25 \text { percent of the total variance. } \\
\text { N/A Data not reported. }\end{array}$} \\
\hline
\end{tabular}


Appendix C Engineered Fill

Appendix C Engineered Fill

CI 


\begin{tabular}{|c|c|c|c|}
\hline \multicolumn{4}{|c|}{$\begin{array}{l}\text { Table C1 } \\
\text { Controlled Moisture Content, Percent }\end{array}$} \\
\hline Mean & $\begin{array}{l}\text { Standard } \\
\text { Deviation } \\
\end{array}$ & $\begin{array}{l}\text { Coefficient of } \\
\text { Variation, Percent }\end{array}$ & Reference \\
\hline 8.3 & 2.6 & 31 & Auff and Choummanivong (1994) \\
\hline 9.1 & 1.3 & 14 & Selig (1966) \\
\hline 9.2 & 1.0 & 10 & \multirow[t]{2}{*}{ Yeo and Auff (1995) } \\
\hline 11 & 1.1 & 11 & \\
\hline 12 & 2.7 & 23 & Auff and Choummanivong (1994) \\
\hline 12 & 2.0 & 16 & Selig (1966) \\
\hline 15 & 3.6 & 24 & David (1967)' \\
\hline
\end{tabular}




\begin{tabular}{|c|c|c|c|}
\hline \multicolumn{4}{|c|}{$\begin{array}{l}\text { Table C2 } \\
\text { Field Com }\end{array}$} \\
\hline Mean & $\begin{array}{l}\text { Standard } \\
\text { Deviation } \\
\end{array}$ & $\begin{array}{l}\text { Coefficient of } \\
\text { Variation, Percent } \\
\end{array}$ & Reference \\
\hline 87.0 & 2.5 & 2.8 & Yeo and Auff (1995) \\
\hline 87.2 & 6.1 & 7.0 & \multirow[t]{4}{*}{ Jorgensen (1968)' } \\
\hline 88.7 & 4.5 & 5.1 & \\
\hline 88.9 & 4.1 & 4.6 & \\
\hline 89.9 & 8.8 & 9.8 & \\
\hline 90.5 & 3.1 & 3.4 & $\begin{array}{l}\text { Sherman, Watkins, and Prysock } \\
(1966)\end{array}$ \\
\hline 91.5 & 3.8 & 4.2 & Yeo and Auff (1995) \\
\hline 92.8 & 2.9 & 3.1 & \multirow{2}{*}{$\begin{array}{l}\text { Auff and Choummanivong } \\
\text { (1994) }\end{array}$} \\
\hline 92.8 & 4.8 & 5.2 & \\
\hline 92.9 & 2.4 & 2.6 & \multirow{2}{*}{$\begin{array}{l}\text { Sherman, Watkins, and Prysock } \\
(1966)^{2}\end{array}$} \\
\hline 93.6 & 5.5 & 5.9 & \\
\hline 94.5 & 3.0 & 3.2 & Brown (1975) \\
\hline 96.6 & 2.9 & 2.9 & \multirow[t]{2}{*}{ Mitchell et al. (1977) } \\
\hline 96.8 & 2.5 & 2.6 & \\
\hline 96.8 & 5.7 & 5.9 & Williamson and Yoder $(1967)^{3}$ \\
\hline 97.3 & 3.7 & 3.8 & David $(1967)^{3}$ \\
\hline 97.8 & 4.9 & 5.0 & Jorgensen (1968) \\
\hline 98.2 & 4.5 & 4.6 & Williamson and Yoder (1967) \\
\hline 98.2 & 3.2 & 3.3 & Mitchell et al. (1977) \\
\hline 99.0 & 4.6 & 4.6 & Nielson $(1967)^{4}$ \\
\hline 99.1 & 4.5 & 4.5 & Van Houten (1967)' \\
\hline 100.6 & 5.3 & 5.3 & Williamson and Yoder $(1967)^{2}$ \\
\hline \multicolumn{4}{|c|}{$\begin{array}{l}\text { Sampling error and experimental error (testing and inherent) accounted for an average } \\
\text { of } 50 \text { percent of the total variance when tested by water balloon. } \\
2 \text { Frequency distributions did not appear to be normal in shape. } \\
\text { Frequency distributions appeared to be normal in shape. } \\
4 \text { Sampling error and experimental error (testing and inherent) accounted for an average } \\
\text { of } 10 \text { percent of the total variance when tested by sand cone. }\end{array}$} \\
\hline
\end{tabular}




\begin{tabular}{|c|c|c|c|}
\hline \multicolumn{4}{|c|}{$\begin{array}{l}\text { Table C3 } \\
\text { Resilient Modulus, MPa }\end{array}$} \\
\hline Mean & $\begin{array}{l}\text { Standard } \\
\text { Deviation }\end{array}$ & $\begin{array}{l}\text { Coefficient of } \\
\text { Variation, Percent }\end{array}$ & Reference \\
\hline N/A & N/A & 20 & Ingles (1972) \\
\hline 83 & 24 & 29 & \multirow{3}{*}{$\begin{array}{l}\text { Kennedy, Hudson, and } \\
\text { McCullough (1975) }\end{array}$} \\
\hline 110 & 24 & 22 & \\
\hline 131 & 29 & 22 & \\
\hline
\end{tabular}

\begin{tabular}{|c|c|c|c|c|}
\hline \multicolumn{5}{|c|}{$\begin{array}{l}\text { Table C4 } \\
\text { Measures of Stiffness and Strength }\end{array}$} \\
\hline Measure & Mean & $\begin{array}{l}\text { Standard } \\
\text { Deviation } \\
\end{array}$ & $\begin{array}{l}\text { Coefficient of } \\
\text { Variation, Percent } \\
\end{array}$ & Reference \\
\hline \multirow{6}{*}{$\begin{array}{l}\text { California } \\
\text { bearing } \\
\text { ratio, percent }\end{array}$} & 7 & 1.5 & 22 & \multirow{2}{*}{$\begin{array}{l}\text { Yoder and Witczak } \\
(1975)\end{array}$} \\
\hline & 8 & 1.4 & 18 & \\
\hline & 12 & 4.1 & 34 & $\begin{array}{l}\text { Yeo and Auff } \\
(1995)^{1}\end{array}$ \\
\hline & 18 & 4.7 & 26 & $\begin{array}{l}\text { Yoder and Witczak } \\
\text { (1975) }\end{array}$ \\
\hline & 21 & 6.7 & 32 & $\begin{array}{l}\text { Yeo and Auff } \\
(1995)\end{array}$ \\
\hline & 43 & 15 & 35 & $\begin{array}{l}\text { Mitchell et al. } \\
(1977)\end{array}$ \\
\hline \multirow{3}{*}{$\begin{array}{l}\text { Modulus of } \\
\text { subgrade reaction, } \\
\mathrm{MPa} / \mathrm{mm}\end{array}$} & N/A & N/A & 33 & $\begin{array}{l}\text { Yoder and Witczak } \\
(1975)\end{array}$ \\
\hline & N/A & N/A & 35 & $\begin{array}{l}\text { Highway Research } \\
\text { Board (1962b) }\end{array}$ \\
\hline & N/A & N/A & 41 & $\begin{array}{l}\text { Kennedy, Hudson, } \\
\text { and McCullough } \\
\text { (1975) }\end{array}$ \\
\hline $\begin{array}{l}\text { Benkelman beam } \\
\text { deflections, } \mathrm{mm}\end{array}$ & 1.4 & 0.35 & 25 & $\begin{array}{l}\text { Yeo and Auff } \\
(1995)\end{array}$ \\
\hline $\begin{array}{l}\text { Dynaflect tests, } \\
\mathrm{MPa}\end{array}$ & N/A & N/A & 34 & $\begin{array}{l}\text { Kennedy, Hudson, } \\
\text { and McCullough } \\
\text { (1975) }\end{array}$ \\
\hline
\end{tabular}




\begin{tabular}{|c|c|c|c|c|}
\hline Measure & Mean & $\begin{array}{l}\text { Standard } \\
\text { Deviation } \\
\end{array}$ & $\begin{array}{l}\text { Coefficient of } \\
\text { Variation, Percent }\end{array}$ & Reference \\
\hline $\begin{array}{l}\text { Unconfined } \\
\text { compressive strength, } \\
\mathrm{MPa}\end{array}$ & N/A & N/A & $\begin{array}{l}11 \\
(1.3 \text { to } 30)\end{array}$ & \multirow[t]{3}{*}{$\begin{array}{l}\text { Liu and } \\
\text { Thompson (1966) }\end{array}$} \\
\hline $\begin{array}{l}\text { Split-tensile strength, } \\
\text { MPa }\end{array}$ & N/A & N/A & $\begin{array}{l}12 \\
(5.0 \text { to } 23)\end{array}$ & \\
\hline Flexural strength, MPa & N/A & N/A & $\begin{array}{l}11 \\
\text { (3.2 to } 19)\end{array}$ & \\
\hline
\end{tabular}




\section{Appendix D \\ Subbase and Base Course Materials}




\begin{tabular}{|c|c|c|c|}
\hline \multicolumn{4}{|c|}{$\begin{array}{l}\text { Table D1 } \\
\text { Controlled Moisture Content, Percent }\end{array}$} \\
\hline Mean & $\begin{array}{l}\text { Standard } \\
\text { Deviation } \\
\end{array}$ & $\begin{array}{l}\text { Coefficient of } \\
\text { Variation, Percent } \\
\end{array}$ & Reference \\
\hline 4.2 & 0.25 & 6.0 & \multirow[t]{3}{*}{ Auff and Yeo (1992) } \\
\hline 4.5 & 0.26 & 5.8 & \\
\hline 5.0 & 0.36 & 7.2 & \\
\hline 5.0 & 0.63 & 12.6 & \multirow[t]{2}{*}{ Auff and Laksmanto (1994) } \\
\hline 5.1 & 0.55 & 10.8 & \\
\hline 5.1 & 0.55 & 10.8 & Auff and Yeo (1992) \\
\hline 5.8 & 0.61 & 10.5 & Auff and Laksmanto (1994) \\
\hline 5.9 & 0.75 & 12.7 & Auff and Laksmanto (1993) \\
\hline 6.6 & 0.58 & 8.8 & Auff and Laksmanto (1994) \\
\hline 6.6 & 0.40 & 6.1 & Autf and Choummanivong (1994) \\
\hline 6.8 & 0.61 & 8.9 & Highway Research Board (1962a) \\
\hline 7.0 & 1.1 & 15.7 & Auff and Choummanivong (1994) \\
\hline 7.3 & 1.2 & 16.3 & \multirow[t]{2}{*}{ Auff and Laksmanto (1993) } \\
\hline 7.4 & 0.40 & 5.4 & \\
\hline 7.9 & 0.73 & 9.2 & Yeo and Auff (1995) \\
\hline 8.2 & 2.0 & 24.4 & Auff and Choummanivong (1994) \\
\hline 8.3 & 0.49 & 5.9 & Auff and Laksmanto (1993) \\
\hline 8.7 & 0.38 & 4.4 & \multirow[t]{3}{*}{ Yeo and Auff (1995) } \\
\hline 9.4 & 0.62 & 6.6 & \\
\hline 9.6 & 0.74 & 7.7 & \\
\hline 9.8 & 1.0 & 10.2 & Auff and Choummanivong (1994) \\
\hline
\end{tabular}




\begin{tabular}{|c|c|c|c|c|}
\hline \multicolumn{5}{|c|}{$\begin{array}{l}\text { Table D2 } \\
\text { Atterberg Limits, Percent }\end{array}$} \\
\hline Property & Mean & $\begin{array}{l}\text { Standard } \\
\text { Deviation } \\
\end{array}$ & $\begin{array}{l}\text { Coefficient of } \\
\text { Variation, Percent }\end{array}$ & Reference \\
\hline \multirow[t]{5}{*}{ Liquid limit } & 12 & 9.8 & 81 & \multirow[t]{5}{*}{ Mitchell et al. (1977) } \\
\hline & 16 & 20 & 128 & \\
\hline & 17 & 2.2 & 13 & \\
\hline & 18 & 6.4 & 37 & \\
\hline & 20 & 1.8 & 9.3 & \\
\hline \multirow{6}{*}{$\begin{array}{l}\text { Plasticity } \\
\text { index }\end{array}$} & 2.9 & 1.0 & 33 & \multirow[t]{4}{*}{ Mitchell et al. (1977) } \\
\hline & 3.0 & 1.3 & 44 & \\
\hline & 3.5 & 2.3 & 65 & \\
\hline & 3.9 & 2.6 & 67 & \\
\hline & 4.0 & 1.0 & 26 & Ingles (1972)' \\
\hline & 5.9 & 1.4 & 24 & Mitchell et al. (1977) \\
\hline
\end{tabular}

\section{Table D3 \\ Coefficient of Permeability, Percent}

\begin{tabular}{||l|l|l|l|l||}
\hline Mean & $\begin{array}{l}\text { Standard } \\
\text { Deviation }\end{array}$ & $\begin{array}{l}\text { Coefficient of } \\
\text { Variation, Percent }\end{array}$ & Comment & Reference \\
\hline \hline N/A & N/A & 240 & Silty sand & Lumb (1972)' \\
\hline \hline $\begin{array}{l}\text { ' Sampling error and experimental error (testing and inherent) accounted for } 1 \text { percent of } \\
\text { the total variance when tested by constant head permeameter. } \\
\text { N/A Data not reported. }\end{array}$
\end{tabular}




\begin{tabular}{|c|c|c|c|c|}
\hline Sieve Size & Mean & $\begin{array}{l}\text { Standard } \\
\text { Deviation } \\
\end{array}$ & $\begin{array}{l}\text { Coefficient of } \\
\text { Variation, } \\
\text { Percent } \\
\end{array}$ & Reference \\
\hline \multirow[t]{7}{*}{$19-\mathrm{mm}$} & 20 & 0.9 & 4.5 & \multirow{4}{*}{ Yeo and Auff (1995) } \\
\hline & 22 & 2.4 & 11 & \\
\hline & 22 & 2.2 & 10 & \\
\hline & 22 & 2.5 & 11 & \\
\hline & 70 & 7.3 & 10 & Willenbrock (1974b) \\
\hline & 80 & 3.9 & 4.9 & Kelley $(1969)^{1}$ \\
\hline & 90 & 2.5 & 2.8 & \\
\hline \multirow[t]{2}{*}{$13.2-\mathrm{mm}$} & 85 & 2.3 & 2.7 & \multirow[t]{2}{*}{ Auff and Yeo (1992) } \\
\hline & 86 & 1.8 & 2.1 & \\
\hline \multirow[t]{4}{*}{$9.5-\mathrm{mm}$} & 42 & 8.1 & 19 & Willenbrock (1974b) \\
\hline & 50 & 5.2 & 10 & Kelley $(1969)^{2}$ \\
\hline & 70 & 2.9 & 4.1 & \multirow[t]{2}{*}{ Auff and Yeo (1992) } \\
\hline & 71 & 2.2 & 3.1 & \\
\hline \multirow{13}{*}{$\begin{array}{l}\text { No. } 4 \\
\text { Sieve }\end{array}$} & 30 & 6.8 & 22 & Willenbrock (1974b) \\
\hline & 34 & 4.3 & 13 & Kelley $(1969)^{\prime}$ \\
\hline & 45 & 6.6 & 15 & \multirow[t]{4}{*}{ State of California (1967) } \\
\hline & 50 & 4.3 & 8.7 & \\
\hline & 51 & 3.1 & 6.1 & \\
\hline & 53 & 5.7 & 11 & \\
\hline & 53 & 2.9 & 5.5 & Auff and Yeo (1992) \\
\hline & 54 & 4.1 & 7.6 & Sherman $(1971)^{2}$ \\
\hline & 55 & 4.9 & 8.9 & Kelley (1969) \\
\hline & 55 & 2.0 & 3.6 & Auff and Yeo (1992) \\
\hline & 56 & 5.8 & 10 & Sherman $(1971)^{3}$ \\
\hline & 58 & 2.8 & 4.8 & \multirow[t]{2}{*}{ State of California (1967) } \\
\hline & 73 & 6.5 & 9.0 & \\
\hline & & & & (Sheet 1 of 3 ) \\
\hline \multicolumn{5}{|c|}{$\begin{array}{l}\text { Sampling error and experimental error (testing and inherent) accounted for } 40 \text { percent } \\
\text { of the total variance. } \\
2 \text { Sampling error and experimental error (testing and inherent) accounted for } 35 \text { percent } \\
\text { of the total variance. } \\
3 \text { Sampling error and experimental error (testing and inherent) accounted for } 20 \text { percent } \\
\text { of the total variance. }\end{array}$} \\
\hline
\end{tabular}




\begin{tabular}{|c|c|c|c|c|}
\hline Sieve Size & Mean & $\begin{array}{l}\text { Standard } \\
\text { Deviation } \\
\end{array}$ & $\begin{array}{l}\text { Coefficient of } \\
\text { Variation, } \\
\text { Percent } \\
\end{array}$ & Reference \\
\hline \multirow{4}{*}{$\begin{array}{l}\text { No. } 8 \\
\text { Sieve }\end{array}$} & 27 & 3.9 & 15 & \multirow[t]{2}{*}{ Mitchell et al. (1977) } \\
\hline & 32 & 4.0 & 12 & \\
\hline & 38 & 2.3 & 6.1 & \multirow[t]{2}{*}{ Auff and Yeo (1992) } \\
\hline & 39 & 2.0 & 5.1 & \\
\hline \multirow[t]{2}{*}{ No. 16} & 20 & 3.6 & 18 & Kelley $(1969)^{\prime}$ \\
\hline & 21 & 5.2 & 25 & Willenbrock (1974b) \\
\hline \multirow[t]{4}{*}{ No. 30} & 24 & 2.9 & 12 & \multirow[t]{2}{*}{ State of California (1967) } \\
\hline & 24 & 2.5 & 11 & \\
\hline & 25 & 2.6 & 10 & Sherman $(1971)^{2}$ \\
\hline & 27 & 2.3 & 8.4 & State of California (1967) \\
\hline \multirow[t]{6}{*}{ No. 50} & 11 & 2.8 & 25 & Kelley $(1969)^{3}$ \\
\hline & 14 & 2.4 & 17 & \multirow[t]{2}{*}{ Mitchell et al. (1977) } \\
\hline & 16 & 2.5 & 15 & \\
\hline & 18 & 1.0 & 5.6 & \multirow[t]{2}{*}{ Auff and Yeo (1992) } \\
\hline & 18 & 1.7 & 9.4 & \\
\hline & 37 & 6.3 & 17 & Kelley (1969) \\
\hline \multirow[t]{2}{*}{ No. 100} & 5.5 & 1.7 & 31 & Willenbrock (1974b) \\
\hline & 6 & 2.7 & 45 & Kelley $(1969)^{4}$ \\
\hline \multirow[t]{5}{*}{ No. 200} & 4.6 & 1.0 & 22 & State of California (1967) \\
\hline & 4.8 & 1.0 & 21 & $\begin{array}{l}\text { Auff and Choummanivong } \\
\text { (1994) }\end{array}$ \\
\hline & 5.7 & 1.2 & 21 & Mitchell et al. (1977) \\
\hline & 6.0 & 0.7 & 12 & State of California (1967) \\
\hline & 6.2 & 0.9 & 15 & Sherman $(1971)^{1}$ \\
\hline \multicolumn{5}{|r|}{ (Sheet 2 of 3 ) } \\
\hline \multicolumn{5}{|c|}{$\begin{array}{l}\text { Sampling error and experimental error (testing and inherent) accounted for } 40 \text { percent } \\
\text { of the total variance. } \\
2 \text { Sampling error and experimental error (testing and inherent) accounted for } 35 \text { percent } \\
\text { of the total variance. } \\
3 \text { Sampling error and experimental error (testing and inherent) accounted for } 20 \text { percent } \\
\text { of the total variance. } \\
4 \text { Sampling error and experimental error (testing and inherent) account for } 30 \text { percent of } \\
\text { the total variance (Liu and Thompson } 1966) \text {. }\end{array}$} \\
\hline
\end{tabular}




\begin{tabular}{|c|c|c|c|c|}
\hline Sieve Size & Mean & $\begin{array}{l}\text { Standard } \\
\text { Deviation }\end{array}$ & $\begin{array}{l}\text { Coefficient of } \\
\text { Variation, } \\
\text { Percent } \\
\end{array}$ & Reference \\
\hline \multirow[t]{18}{*}{$\begin{array}{l}\text { No. } 200 \\
\text { (Cont.) }\end{array}$} & 7.4 & 1.9 & 26 & $\begin{array}{l}\text { Auff and Choummanivong } \\
(1994)\end{array}$ \\
\hline & 7.8 & 1.3 & 17 & State of California (1967) \\
\hline & 7.9 & 1.1 & 14 & \\
\hline & 8.6 & 1.7 & 20 & \\
\hline & 8.8 & 1.6 & 18 & Sherman $(1971)^{2}$ \\
\hline & 9.0 & 0.6 & 6.7 & \multirow[t]{2}{*}{ Auff and Yeo (1992) } \\
\hline & 9.0 & 0.8 & 9.0 & \\
\hline & 9.0 & 0.6 & 6.7 & \multirow{2}{*}{$\begin{array}{l}\text { Auff and Laksmanto } \\
\text { (1994) }\end{array}$} \\
\hline & 10 & 1.1 & 11 & \\
\hline & 10 & 1.8 & 18 & State of California (1967) \\
\hline & 13 & 1.2 & 9.2 & $\begin{array}{l}\text { Auff and Laksmanto } \\
(1994)\end{array}$ \\
\hline & 13 & 0.9 & 7.0 & \multirow{2}{*}{$\begin{array}{l}\text { Auff and Choummanivong } \\
\text { (1994) }\end{array}$} \\
\hline & 16 & 1.8 & 11 & \\
\hline & 16 & 2.9 & 18 & Kelley (1969) \\
\hline & 20 & 0.9 & 4.5 & \multirow[t]{4}{*}{ Yeo and Auff (1995) } \\
\hline & 21 & 2.4 & 11 & \\
\hline & 22 & 2.2 & 10 & \\
\hline & 22 & 2.5 & 11 & \\
\hline & & & & (Sheet 3 of 3 ) \\
\hline
\end{tabular}




\begin{tabular}{|c|c|c|c|}
\hline \multicolumn{4}{|c|}{$\begin{array}{l}\text { Table D5 } \\
\text { Sand Equivalence, Percent } \\
\end{array}$} \\
\hline Mean & $\begin{array}{l}\text { Standard } \\
\text { Deviation } \\
\end{array}$ & $\begin{array}{l}\text { Coefficient of } \\
\text { Variation, Percent } \\
\end{array}$ & Reference \\
\hline 29 & 2.7 & 9.2 & \multirow[t]{3}{*}{ State of California (1967) } \\
\hline 30 & 4.0 & 13 & \\
\hline 31 & 6.1 & 20 & \\
\hline 32 & 5.1 & 16 & Sherman $(1971)^{\prime}$ \\
\hline 36 & 8.5 & 23 & \multirow[t]{2}{*}{ State of California (1967) } \\
\hline 43 & 4.0 & 9.3 & \\
\hline 44 & 4.7 & 11 & Sherman $(1971)^{2}$ \\
\hline 59 & 4.0 & 6.8 & State of California (1967) \\
\hline \multicolumn{4}{|c|}{$\begin{array}{l}\text { Sampling error and experimental error (testing and inherent) accounted for } 35 \text { percent } \\
\text { of the total variance. } \\
\text { Sampling error and experimental error (testing and inherent) accounted for } 20 \text { percent } \\
\text { of the total variance. }\end{array}$} \\
\hline
\end{tabular}

\begin{tabular}{|c|c|c|c|}
\hline \multicolumn{4}{|c|}{$\begin{array}{l}\text { Table D6 } \\
\text { Magnesium Sulfate Soundness, Percent }\end{array}$} \\
\hline Mean & $\begin{array}{l}\text { Standard } \\
\text { Deviation } \\
\end{array}$ & $\begin{array}{l}\text { Coefficient of } \\
\text { Variation, } \\
\text { Percent } \\
\end{array}$ & Reference \\
\hline 5.6 & 0.48 & 8.5 & \multirow{5}{*}{$\begin{array}{l}\text { New York State Department of } \\
\text { Public Works }(1964)\end{array}$} \\
\hline 17 & 0.22 & 1.3 & \\
\hline 23 & 0.24 & 1.0 & \\
\hline 47 & 1.17 & 2.5 & \\
\hline 48 & 1.46 & 3.1 & \\
\hline
\end{tabular}




\begin{tabular}{|c|c|c|c|c|}
\hline \multicolumn{5}{|c|}{$\begin{array}{l}\text { Table D7 } \\
\text { Lift Thickness, mm }\end{array}$} \\
\hline Mean & $\begin{array}{l}\text { Standard } \\
\text { Deviation } \\
\end{array}$ & $\begin{array}{l}\text { Coefficient of } \\
\text { Variation, Percent } \\
\end{array}$ & Comment & Reference \\
\hline 134 & 8.4 & 6.3 & \multirow[t]{3}{*}{ Subbase' } & Mitchell et al. (1977) \\
\hline 307 & 35 & 11 & & \multirow{2}{*}{$\begin{array}{l}\text { Auff and } \\
\text { Choummanivong } \\
(1994)\end{array}$} \\
\hline 343 & 54 & 16 & & \\
\hline 93 & 17 & 18 & \multirow[t]{11}{*}{ Base' } & $\begin{array}{l}\text { Auff and Laksmanto } \\
(1994)\end{array}$ \\
\hline 97 & 5.4 & 5.6 & & Auff and Yeo (1992) \\
\hline 98 & 13 & 14 & & $\begin{array}{l}\text { Auff and Laksmanto } \\
\text { (1994) }\end{array}$ \\
\hline 103 & 6.2 & 6.0 & & Auff and Yeo (1992) \\
\hline 104 & 23 & 22 & & $\begin{array}{l}\text { Auff and Laksmanto } \\
(1994)\end{array}$ \\
\hline 114 & 11 & 9.6 & & \multirow[t]{2}{*}{ Mitchell et al. (1977) } \\
\hline 131 & 11 & 8.3 & & \\
\hline 131 & 18 & 14 & & \multirow{2}{*}{$\begin{array}{l}\text { Auff and } \\
\text { Choummanivong } \\
\text { (1994) }\end{array}$} \\
\hline 133 & 19 & 14 & & \\
\hline 145 & 29 & 20 & & \multirow{2}{*}{$\begin{array}{l}\text { Auff and Laksmanto } \\
\text { (1993) }\end{array}$} \\
\hline 147 & 27 & 18 & & \\
\hline
\end{tabular}




\begin{tabular}{|c|c|c|c|}
\hline \multicolumn{4}{|c|}{$\begin{array}{l}\text { Table D8 } \\
\text { Field Compaction for Subbase Materials', Percent Relative to } \\
\text { Laboratory Density }\end{array}$} \\
\hline Mean & $\begin{array}{l}\text { Standard } \\
\text { Deviation } \\
\end{array}$ & $\begin{array}{l}\text { Coefficient of } \\
\text { Variation, Percent } \\
\end{array}$ & Reference \\
\hline 89.4 & 3.3 & 3.7 & \multirow[t]{3}{*}{ Williamson and Yoder (1967) } \\
\hline 91.7 & 3.1 & 3.4 & \\
\hline 93.6 & 2.3 & 2.5 & \\
\hline 94.8 & 3.5 & 3.7 & Brown (1975) \\
\hline 98.1 & 2.9 & 3.0 & Nielson $(1967)^{2}$ \\
\hline 98.2 & 2.1 & 2.2 & Mitchell et al. (1977) \\
\hline 98.7 & 2.9 & 3.0 & Van Houten $(1967)^{3}$ \\
\hline 99.4 & 2.4 & 2.4 & Mitchell et al. (1977) \\
\hline 99.4 & 2.1 & 2.1 & $\begin{array}{l}\text { Auff and Choummanivong } \\
(1994)\end{array}$ \\
\hline 100.1 & 1.2 & 1.2 & Auff and Laksmanto (1993) \\
\hline 100.8 & 2.3 & 2.3 & David (1967) \\
\hline 100.9 & 3.8 & 3.8 & $\begin{array}{l}\text { Auff and Choummanivong } \\
\text { (1994) }\end{array}$ \\
\hline 105.3 & 1.2 & 1.1 & Auff and Laksmanto (1993) \\
\hline \multicolumn{4}{|c|}{$\begin{array}{l}\text { Both unstabilized and stabilized. } \\
\text { Sampling error and experimental error (testing and inherent) accounted for } 15 \text { percent } \\
\text { of the total variance. } \\
\text { Sampling error and experimental error (testing and inherent) accounted for } 25 \text { percent } \\
\text { of the total variance. }\end{array}$} \\
\hline
\end{tabular}




\begin{tabular}{|c|c|c|c|}
\hline \multicolumn{4}{|c|}{$\begin{array}{l}\text { Table D9 } \\
\text { Field Compaction for Base Course Materials', Percent Relative to } \\
\text { Laboratory Density }\end{array}$} \\
\hline Mean & $\begin{array}{l}\text { Standard } \\
\text { Deviation } \\
\end{array}$ & $\begin{array}{l}\text { Coefficient of } \\
\text { Variation, Percent } \\
\end{array}$ & Reference \\
\hline 94.3 & 2.2 & 2.3 & Yeo and Auff (1995) \\
\hline 95.6 & 1.5 & 1.6 & \multirow[t]{2}{*}{ Brown (1975) } \\
\hline 96.6 & 1.3 & 1.3 & \\
\hline 97.5 & 2.1 & 2.2 & Mitchell et al. (1977) \\
\hline 97.8 & 1.0 & 1.0 & \multirow[t]{2}{*}{ Brown (1975) } \\
\hline 98.5 & 2.5 & 2.5 & \\
\hline 99.2 & 4.1 & 4.1 & David (1967) \\
\hline 99.2 & 0.7 & 0.7 & Brown (1975) \\
\hline 99.5 & 2.8 & 2.8 & Yeo and Auff (1995) \\
\hline 99.6 & 1.3 & 1.3 & \multirow[t]{2}{*}{ Mitchell et al. (1977) } \\
\hline 100.0 & 2.0 & 2.0 & \\
\hline 100.0 & 0.8 & 0.8 & Brown (1975) \\
\hline 100.5 & 2.2 & 2.2 & Yeo and Auff (1995) \\
\hline 100.7 & 1.9 & 1.9 & Mitchell et al. (1977) \\
\hline 101.2 & 0.7 & 0.7 & Auff and Yeo (1992) \\
\hline 101.3 & 2.2 & 2.2 & Auff and Laksmanto (1994) \\
\hline 101.4 & 1.9 & 1.9 & Yeo and Auff (1995) \\
\hline 101.6 & 2.8 & 2.8 & Auff and Choummanivong (1994) \\
\hline 101.7 & 1.6 & 1.6 & Auff and Laksmanto (1993) \\
\hline 102.3 & 0.7 & 0.7 & Auff and Yeo (1992) \\
\hline 102.5 & 1.8 & 1.8 & Auff and Laksmanto (1994) \\
\hline 103.0 & 1.4 & 1.4 & \multirow[t]{2}{*}{ Auff and Yeo (1992) } \\
\hline 103.2 & 1.2 & 1.2 & \\
\hline 103.3 & 1.9 & 1.8 & Auff and Laksmanto (1993) \\
\hline 104.0 & 2.7 & 2.6 & Auff and Choummanivong (1994) \\
\hline 104.2 & 2.2 & 2.1 & \multirow{2}{*}{ Auff and Laksmanto (1994) } \\
\hline 104.9 & 1.5 & 1.4 & \\
\hline
\end{tabular}




\begin{tabular}{|c|c|c|c|c|}
\hline \multicolumn{5}{|c|}{$\begin{array}{l}\text { Table D10 } \\
\text { Measures of Stiffness and Strength }\end{array}$} \\
\hline Measure & Mean & $\begin{array}{l}\text { Standard } \\
\text { Deviation } \\
\end{array}$ & $\begin{array}{l}\text { Coefficient of } \\
\text { Variation, } \\
\text { Percent }\end{array}$ & Reference \\
\hline $\begin{array}{l}\text { Angle of internal } \\
\text { friction, } \phi\end{array}$ & N/A & N/A & 5 to 12 & $\begin{array}{l}\text { Schultze } \\
(1972)^{2} \\
\end{array}$ \\
\hline $\begin{array}{l}\text { Unconfined } \\
\text { compressive } \\
\text { strength, } \mathrm{kPa} \\
\end{array}$ & N/A & N/A & $\begin{array}{l}11 \\
\text { (3 to } 27)\end{array}$ & $\begin{array}{l}\text { Liu and } \\
\text { Thompson } \\
\text { (1966) }\end{array}$ \\
\hline \multirow[t]{4}{*}{$\begin{array}{l}\text { California bearing } \\
\text { ratio, percent }\end{array}$} & 26 & 8.3 & 32 & $\begin{array}{l}\text { Yoder and } \\
\text { Witczak } \\
(1975)^{2} \\
\end{array}$ \\
\hline & 59 & 13 & 22 & $\begin{array}{l}\text { Mitchell et al. } \\
(1977)^{2}\end{array}$ \\
\hline & 94 & 36 & 38 & $\begin{array}{l}\text { Yoder and } \\
\text { Witczak } \\
(1975)^{2}\end{array}$ \\
\hline & N/A & N/A & $\begin{array}{l}15 \\
(7 \text { to } 26)\end{array}$ & $\begin{array}{l}\text { Liu and } \\
\text { Thompson } \\
(1966)^{3} \\
\end{array}$ \\
\hline \multirow{4}{*}{$\begin{array}{l}\text { Benkelman beam } \\
\text { deflections, } \mathrm{mm}\end{array}$} & 0.9 & 0.2 & 24 & \multirow{4}{*}{$\begin{array}{l}\text { Yeo and Auff } \\
\text { (1995) }\end{array}$} \\
\hline & 1.0 & 0.2 & 18 & \\
\hline & 1.1 & 0.3 & 24 & \\
\hline & 1.3 & 0.3 & 22 & \\
\hline \multicolumn{5}{|c|}{$\begin{array}{l}\text { Normality was rejected by the chi square "goodness-of-fit" test, however, normality } \\
\text { was not rejected for cot } \phi \text {. } \\
2 \text { Performed in the field. } \\
3 \text { Performed in the laboratory. } \\
\text { N/A Data not reported. }\end{array}$} \\
\hline
\end{tabular}




\begin{tabular}{|c|c|c|c|c|}
\hline \multicolumn{5}{|c|}{$\begin{array}{l}\text { Table D11 } \\
\text { Measures of Stiffness and Strength for Lime- and Cement- } \\
\text { Stabilized Subbase and Base Course Materials }\end{array}$} \\
\hline Measure & Mean & $\begin{array}{l}\text { Standard } \\
\text { Deviation } \\
\end{array}$ & $\begin{array}{l}\text { Coefficient of } \\
\text { Variation, } \\
\text { Percent }\end{array}$ & Reference \\
\hline \multirow{2}{*}{$\begin{array}{l}\text { Unconfined } \\
\text { compressive } \\
\text { strength, } \mathrm{kPa}\end{array}$} & 5,792 & 841 & 15 & $\begin{array}{l}\text { Highway Research Board } \\
\text { (1962a) }\end{array}$ \\
\hline & N/A & N/A & $\begin{array}{l}15 \\
(4 \text { to } 24) \\
\end{array}$ & $\begin{array}{l}\text { Lui and Thompson } \\
(1966)\end{array}$ \\
\hline $\begin{array}{l}\text { Compression } \\
\text { modulus, MPa } \\
\end{array}$ & 4,000 & 2,400 & 60 & $\begin{array}{l}\text { Marshall and Kennedy } \\
\text { (1974) }\end{array}$ \\
\hline $\begin{array}{l}\text { Indirect tensile } \\
\text { strength, } \mathrm{kPa}\end{array}$ & 938 & 338 & 36 & \multirow[t]{2}{*}{$\begin{array}{l}\text { Kennedy, Hudson, and } \\
\text { McCullough (1975) }\end{array}$} \\
\hline $\begin{array}{l}\text { Tensile } \\
\text { modulus, MPa } \\
\end{array}$ & 621 & 421 & 68 & \\
\hline \multirow{3}{*}{$\begin{array}{l}\text { California } \\
\text { bearing ratio, } \\
\text { percent }\end{array}$} & 216 & 81 & 38 & \multirow[t]{2}{*}{ Mitchell et al. $(1977)^{2}$} \\
\hline & 307 & 95 & 31 & \\
\hline & N/A & N/A & $\begin{array}{l}15 \\
(3 \text { to } 31) \\
\end{array}$ & $\begin{array}{l}\text { Lui and Thompson } \\
(1966)^{3}\end{array}$ \\
\hline $\begin{array}{l}\text { Plate-load } \\
\text { tests, } \mathrm{MPa} / \mathrm{mm}\end{array}$ & N/A & N/A & 71 & \multirow[t]{2}{*}{$\begin{array}{l}\text { Kennedy, Hudson, and } \\
\text { McCullough (1975) }\end{array}$} \\
\hline $\begin{array}{l}\text { Dynaflect tests, } \\
\mathrm{MPa}\end{array}$ & N/A & N/A & 22 & \\
\hline \multicolumn{5}{|c|}{$\begin{array}{l}\text { Frequency distributions appeared to be normal in shape. } \\
2 \text { Performed in the field. } \\
\text { Performed in the laboratory. } \\
\text { N/A Data not reported. }\end{array}$} \\
\hline
\end{tabular}




\begin{tabular}{|c|c|c|c|c|}
\hline \multicolumn{5}{|c|}{$\begin{array}{l}\text { Table D12 } \\
\text { Measures of Stiffness and Strength for Asphalt-Stabilized Base } \\
\text { Course Materials }\end{array}$} \\
\hline Measure & Mean & $\begin{array}{l}\text { Standard } \\
\text { Deviation } \\
\end{array}$ & $\begin{array}{l}\text { Coefficient of } \\
\text { Variation, } \\
\text { Percent }\end{array}$ & Reference \\
\hline $\begin{array}{l}\text { Indirect tensile } \\
\text { strength, } \mathrm{kPa} \\
\end{array}$ & 724 & 152 & 21 & \multirow[t]{3}{*}{$\begin{array}{l}\text { Marshall and } \\
\text { Kennedy }(1974)\end{array}$} \\
\hline $\begin{array}{l}\text { Tensile modulus, } \\
\mathrm{MPa}\end{array}$ & 401 & 144 & 36 & \\
\hline $\begin{array}{l}\text { Indirect poisson's } \\
\text { ratio }\end{array}$ & 0.27 & 0.13 & 48 & \\
\hline \multirow{6}{*}{$\begin{array}{l}\text { Flexural stiffness, } \\
\mathrm{MPa}\end{array}$} & 821 & 131 & $16^{\prime}$ & \multirow[t]{2}{*}{ Finn (1967) } \\
\hline & 1,007 & 255 & $25^{2}$ & \\
\hline & 1,014 & 283 & $28^{2}$ & \multirow{2}{*}{$\begin{array}{l}\text { Monismith et al. } \\
(1967)\end{array}$} \\
\hline & 3,034 & 607 & $20^{2}$ & \\
\hline & 3,613 & 1,193 & $33^{2}$ & \multirow[t]{2}{*}{ Finn (1967) } \\
\hline & 3,661 & 1,027 & $28^{\prime}$ & \\
\hline $\begin{array}{l}\text { Fatigue life of } \\
\text { beams }\end{array}$ & N/A & N/A & 30 to $75^{3}$ & $\begin{array}{l}\text { Moore and } \\
\text { Kennedy (1971) } \\
\end{array}$ \\
\hline \multicolumn{5}{|c|}{$\begin{array}{l}\text { Laboratory-molded specimens. } \\
\text { Specimens obtained from the field. } \\
\text { Standard deviation increased linearly with increasing fatigue life. } \\
\text { Note: Frequency distributions for indirect tensile strength appeared to be normal in shape } \\
\text { (Kennedy. Hudson, and McCullough } 1975 \text { ). } \\
\text { N/A Data not reported. }\end{array}$} \\
\hline
\end{tabular}




\section{Appendix E Asphalt Concrete}




\begin{tabular}{|c|c|c|c|c|}
\hline \multicolumn{5}{|c|}{$\begin{array}{l}\text { Table E1 } \\
\text { Properties of Extracted Asphalt Cement }\end{array}$} \\
\hline Property & Mean & $\begin{array}{l}\text { Standard } \\
\text { Deviation }\end{array}$ & $\begin{array}{l}\text { Coefficient of } \\
\text { Variation, Percent }\end{array}$ & Reference \\
\hline \multirow{5}{*}{$\begin{array}{l}\text { Penetration at } \\
25^{\circ} \mathrm{C}, 0.1 \mathrm{~mm}\end{array}$} & 21 & 2.3 & 11 & \multirow[t]{5}{*}{ Sherman (1971) } \\
\hline & 32 & 9.6 & 30 & \\
\hline & 35 & 4.3 & 12 & \\
\hline & 47 & 18 & 38 & \\
\hline & 48 & 14 & 30 & \\
\hline \multirow{5}{*}{$\begin{array}{l}\text { Viscosity at } 60^{\circ} \mathrm{C}, \\
\text { Pa-s }\end{array}$} & 910 & 560 & 62 & \multirow[t]{5}{*}{ Sherman (1971) } \\
\hline & 940 & 240 & 26 & \\
\hline & 1,160 & 1,120 & 97 & \\
\hline & 1,900 & 1,270 & 67 & \\
\hline & 4,680 & 790 & 17 & \\
\hline
\end{tabular}

\section{Table E2 \\ Mixture Temperature in the Field}

\begin{tabular}{||l|l|l|l||}
\hline \hline Mean & $\begin{array}{l}\text { Standard } \\
\text { Deviation }\end{array}$ & $\begin{array}{l}\text { Coefficient of } \\
\text { Variation, Percent }\end{array}$ & Reference \\
\hline \hline 135 & 7.4 & $\begin{array}{c}5.5 \\
(2.2 \text { to } 8.0)\end{array}$ & Kilpatrick and McQuate (1967) \\
\hline 153 & 9.0 & 5.9 & Oglio and Zenewitz (1965)' \\
\hline \hline $\begin{array}{l}\text { I Sampling error and experimental error (testing and inherent) accounted for 2 percent of } \\
\text { the total variance. }\end{array}$
\end{tabular}




\begin{tabular}{|c|c|c|c|}
\hline \multicolumn{4}{|c|}{$\begin{array}{l}\text { Table E3 } \\
\text { Extracted Asphalt Cement Content, Percent }\end{array}$} \\
\hline Mean & $\begin{array}{l}\text { Standard } \\
\text { Deviation } \\
\end{array}$ & $\begin{array}{l}\text { Coefficient of } \\
\text { Variation, Percent }\end{array}$ & Reference \\
\hline 4.0 & 0.18 & 4.5 & Shook (1966) \\
\hline 4.2 & 0.13 & 3.1 & Highway Research Board. (1962a) \\
\hline 4.3 & 0.39 & 9.0 & \multirow[t]{2}{*}{ Shook (1966) } \\
\hline 4.4 & 0.20 & 4.5 & \\
\hline 4.5 & 0.30 & 6.6 & Gartner (1965) \\
\hline 4.9 & 0.33 & 6.7 & Hode-Keyser and Wade (1963) \\
\hline 5.1 & 0.38 & 7.5 & Adams and Shah (1965) \\
\hline 5.2 & 0.18 & 3.5 & Highway Research Board. (1962a) \\
\hline 5.3 & 0.18 & 3.4 & Adams and Shah (1965) \\
\hline 5.3 & 0.28 & 5.2 & \multirow[t]{2}{*}{ Shook (1966) } \\
\hline 5.4 & 0.17 & 3.1 & \\
\hline 5.4 & 0.13 & 2.4 & Mitchell et al. (1977) \\
\hline 5.4 & 0.16 & 3.0 & Adams and Shah (1965) \\
\hline 5.6 & 0.14 & 2.6 & Shook (1966) \\
\hline 5.8 & 0.39 & 6.8 & Gartner (1965) \\
\hline 6.0 & 0.12 & 2.0 & \multirow[t]{2}{*}{ Shook (1966) } \\
\hline 6.0 & 0.20 & 3.4 & \\
\hline 6.0 & 0.12 & 2.0 & Oglio and Zenewitz (1965) \\
\hline 6.2 & 0.35 & 5.7 & \multirow[t]{2}{*}{ Shook (1966) } \\
\hline 6.4 & 0.29 & 4.5 & \\
\hline 6.4 & 0.22 & 3.5 & Hode-Keyser and Wade (1963) \\
\hline
\end{tabular}




\begin{tabular}{|c|c|c|c|c|}
\hline \multicolumn{5}{|c|}{$\begin{array}{l}\text { Table E4 } \\
\text { Particle Size Distribution for Extracted Aggregates, Percent Finer }\end{array}$} \\
\hline Sieve Size & Mean & $\begin{array}{l}\text { Standard } \\
\text { Deviation }\end{array}$ & $\begin{array}{l}\text { Coefficient of } \\
\text { Variation, Percent }\end{array}$ & Reference \\
\hline $25 \mathrm{~mm}$ & 94 & 4.5 & 4.8 & SCSHD (1966) \\
\hline $19 \mathrm{~mm}$ & 93 & 1.4 & 1.5 & Granley (1969) \\
\hline \multirow[t]{2}{*}{$13 \mathrm{~mm}$} & 92 & 3.2 & 3.4 & SCSHD (1966) \\
\hline & 99 & 0.9 & 0.9 & Mitchell et al. (1977) \\
\hline \multirow[t]{2}{*}{$9.5 \mathrm{~mm}$} & 98 & 1.7 & 1.8 & Oglio and Zenewitz (1965) \\
\hline & 86 & 2.5 & 2.9 & Granley (1969) \\
\hline & & & & ISheet 1 \\
\hline \multicolumn{5}{|c|}{$\begin{array}{l}\text { Note: Sampling error and experimental error (testing and inherent) accounted for the } \\
\text { following percentages of total variance. } \\
-25 \text {-mm sieve: } 85 \text { percent (SCSHD 1966). } \\
\text { 19-mm sieve: } 75 \text { percent (Granley 1969). } \\
\text { 13-mm sieve: } 65 \text { percent (SCSHD 1966). } \\
\text { 9.5-mm sieve: } 60 \text { percent (Granley 1969). }\end{array}$} \\
\hline
\end{tabular}




\begin{tabular}{|c|c|c|c|c|}
\hline Sieve Size & Mean & $\begin{array}{l}\text { Standard } \\
\text { Deviation } \\
\end{array}$ & $\begin{array}{l}\text { Coefficient of } \\
\text { Variation, Percent } \\
\end{array}$ & Reference \\
\hline \multirow[t]{29}{*}{$4.75 \mathrm{~mm}$} & 36 & 2.2 & 6.1 & Highway Research Board (1962a) \\
\hline & 41 & 4.5 & 11 & Shook (1966) \\
\hline & 43 & 4.5 & 11 & SCSHD (1966) \\
\hline & 50 & 3.0 & 5.9 & Hode-Keyser and Wade (1963) \\
\hline & 51 & 3.3 & 6.5 & Shook $(1966)$ \\
\hline & 54 & 3.5 & 6.4 & Mitchell et al. (1977) \\
\hline & 60 & 3.4 & 5.7 & \multirow[t]{3}{*}{ Shook (1966) } \\
\hline & 61 & 2.0 & 3.2 & \\
\hline & 62 & 3.7 & 6.0 & \\
\hline & 62 & 4.2 & 6.7 & Oglio and Zenewitz (1965) \\
\hline & 62 & 4.1 & 6.7 & SRCWV (1966) \\
\hline & 63 & 4.0 & 6.4 & Highway Research Board (1962a) \\
\hline & 64 & 3.5 & 5.5 & Granley (1969) \\
\hline & 65 & 4.3 & 6.6 & SCSHD (1966) \\
\hline & 65 & 3.5 & 5.4 & Adams and Shah (1965) \\
\hline & 65 & 1.6 & 2.4 & \multirow[t]{2}{*}{ Shook (1966) } \\
\hline & 66 & 1.8 & 2.7 & \\
\hline & 66 & 2.6 & 4.0 & Adams and Shah (1965) \\
\hline & 66 & 4.7 & 7.2 & SRCWV (1966) \\
\hline & 67 & 3.9 & 5.9 & Shook (1966) \\
\hline & 68 & 4.8 & 7.1 & SRCWV (1966) \\
\hline & 68 & 3.9 & 5.7 & \multirow{2}{*}{ Adams and Shah (1965) } \\
\hline & 69 & 4.7 & 6.8 & \\
\hline & 69 & 4.5 & 6.5 & \multirow[t]{3}{*}{ SRCWV (1966) } \\
\hline & 70 & 4.8 & 6.9 & \\
\hline & 72 & 5.1 & 7.1 & \\
\hline & 73 & 2.3 & 3.2 & \multirow[t]{2}{*}{ Shook (1966) } \\
\hline & 78 & 2.7 & 3.5 & \\
\hline & 88 & 0.8 & 0.9 & Hode-Keyser and Wade (1963) \\
\hline \multicolumn{5}{|r|}{ (Sheet 2 of 4 ) } \\
\hline & & $\begin{array}{l}\text { sampling } \\
\text { ent of the } \\
1966 \text { : SF } \\
\end{array}$ & $\begin{array}{l}\text { or and experimental } \\
\text { al variance (Granley } \\
\text { VV 1966). }\end{array}$ & $\begin{array}{l}\text { Irror (testing and inherent) } \\
\text { 969: SCSHD 1966; Oglio and } \\
\end{array}$ \\
\hline
\end{tabular}




\begin{tabular}{|c|c|c|c|c|}
\hline Sieve Size & Mean & $\begin{array}{l}\text { Standard } \\
\text { Deviation } \\
\end{array}$ & $\begin{array}{l}\text { Coefficient of } \\
\text { Variation, Percent } \\
\end{array}$ & Reference \\
\hline \multirow[t]{2}{*}{$2.36 \mathrm{~mm}$} & 36 & 2.9 & 8.0 & Mitchell et al. (1977) \\
\hline & 42 & 2.8 & 6.7 & Granley (1969) \\
\hline \multirow[t]{3}{*}{$2.0 \mathrm{~mm}$} & 35 & 3.7 & 11 & SCSHD (1966) \\
\hline & 39 & 2.1 & 5.5 & Oglio and Zenewitz (1965) \\
\hline & 55 & 4.0 & 7.4 & SCSHD (1966) \\
\hline $0.85 \mathrm{~mm}$ & 26 & 2.1 & 7.8 & Oglio and Zenewitz (1965) \\
\hline $0.6 \mathrm{~mm}$ & 26 & 1.7 & 6.7 & Granley (1969) \\
\hline \multirow{3}{*}{$\begin{array}{l}0.425 \\
\mathrm{~mm}\end{array}$} & 18 & 1.7 & 9.2 & Oglio and Zenewitz (1965) \\
\hline & 20 & 3.6 & 18 & \multirow[t]{2}{*}{ SCSHD (1966) } \\
\hline & 29 & 2.1 & 7.2 & \\
\hline \multirow[t]{2}{*}{$0.3 \mathrm{~mm}$} & 15 & 1.6 & 11 & Mitchell et al. (1977) \\
\hline & 15 & 1.4 & 9.1 & Granley (1969) \\
\hline $0.18 \mathrm{~mm}$ & 9.5 & 1.5 & 15 & Oglio and Zenewitz (1965) \\
\hline \multirow[t]{2}{*}{$0.15 \mathrm{~mm}$} & 9.0 & 1.0 & 11 & Granley (1969) \\
\hline & & & & (Sheet 3 of 4 ) \\
\hline \multicolumn{5}{|c|}{ 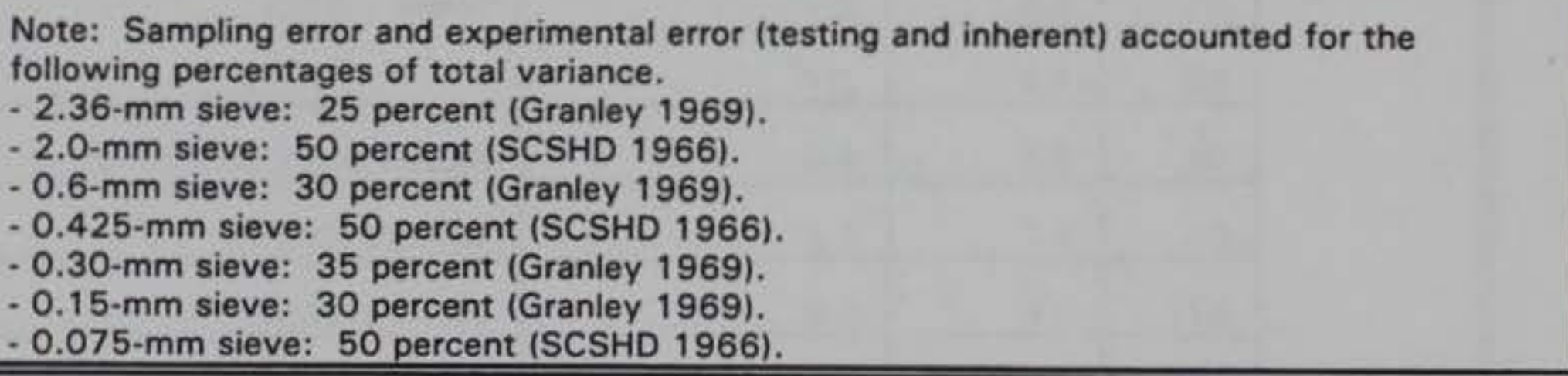 } \\
\hline
\end{tabular}




\begin{tabular}{|c|c|c|c|c|}
\hline Sieve Size & Mean & $\begin{array}{l}\text { Standard } \\
\text { Deviation } \\
\end{array}$ & $\begin{array}{l}\text { Coefficient of } \\
\text { Variation, Percent }\end{array}$ & Reference \\
\hline \multirow[t]{22}{*}{ No. 200} & 2.6 & 0.5 & 19 & Hode-Keyser and Wade (1963) \\
\hline & 4.1 & 0.6 & 13 & Shook (1966) \\
\hline & 4.3 & 0.5 & 11 & Highway Research Board (1962a) \\
\hline & 4.3 & 0.7 & 16 & SCSHD (1966) \\
\hline & 4.9 & 1.0 & 20 & Shook (1966) \\
\hline & 5.6 & 1.2 & 21 & Oglio and Zenewitz (1965) \\
\hline & 5.6 & 1.2 & 21 & \multirow[t]{2}{*}{ Shook (1966) } \\
\hline & 5.8 & 1.1 & 20 & \\
\hline & 5.9 & 1.2 & 20 & Highway Research Board (1962a) \\
\hline & 6.0 & 0.9 & 16 & Granley (1969) \\
\hline & 6.0 & 1.0 & 17 & Shook (1966) \\
\hline & 6.4 & 1.0 & 16 & SCSHD (1966) \\
\hline & 7.0 & 1.1 & 16 & Adams and Shah (1965) \\
\hline & 7.1 & 0.8 & 11 & Mitchell et al. (1977) \\
\hline & 7.1 & 1.0 & 14 & Adams and Shah (1965) \\
\hline & 7.3 & 1.0 & 13 & Shook (1966) \\
\hline & 7.5 & 1.3 & 17 & Adams and Shah (1965) \\
\hline & 7.9 & 0.7 & 9.3 & Shook (1966) \\
\hline & 8.0 & 1.3 & 16 & Adams and Shah (1965) \\
\hline & 9.6 & 0.9 & 9.0 & \multirow[t]{2}{*}{ Shook (1966) } \\
\hline & 10 & 1.0 & 9.5 & \\
\hline & 10 & 0.8 & 8.1 & Hode-Keyser and Wade (1963) \\
\hline \multicolumn{5}{|r|}{ (Sheet 4 of 4 ) } \\
\hline
\end{tabular}




\begin{tabular}{|c|c|c|c|c|}
\hline $\begin{array}{l}\text { Table E5 } \\
\text { Laboratory } \\
\end{array}$ & ensity an & Voids A & yses & \\
\hline Property & Mean & $\begin{array}{l}\text { Standard } \\
\text { Deviation } \\
\end{array}$ & $\begin{array}{l}\text { Coefficient of } \\
\text { Variation, } \\
\text { Percent } \\
\end{array}$ & Reference \\
\hline \multirow{2}{*}{$\begin{array}{l}\text { Bulk specific } \\
\text { gravity }\end{array}$} & 2.353 & 0.038 & 1.6 & \multirow{2}{*}{$\begin{array}{l}\text { Highway Research } \\
\text { Board (1962a) }\end{array}$} \\
\hline & 2.388 & 0.026 & 1.1 & \\
\hline $\begin{array}{l}\text { Theo. Max. } \\
\text { specific } \\
\text { gravity }\end{array}$ & 2.460 & 0.011 & 0.4 & Granley $(1969)^{1}$ \\
\hline \multirow{9}{*}{$\begin{array}{l}\text { Voids total } \\
\text { mix, percent }\end{array}$} & 1.8 & 0.8 & 44 & \multirow[t]{4}{*}{ Sherman (1971) } \\
\hline & 2.3 & 1.5 & 65 & \\
\hline & 2.4 & 0.4 & 17 & \\
\hline & 2.5 & 1.5 & 60 & \\
\hline & 4.3 & 1.0 & 23 & Granley $(1969)^{2}$ \\
\hline & 4.9 & 0.8 & 17 & Mitchell et al. (1977) \\
\hline & 5.7 & 0.9 & 16 & Sherman (1971) \\
\hline & 6.5 & 1.5 & 23 & \multirow{2}{*}{$\begin{array}{l}\text { Highway Research } \\
\text { Board }(1962 a)\end{array}$} \\
\hline & 7.7 & 1.0 & 13 & \\
\hline \multirow{7}{*}{$\begin{array}{l}\text { Voids filled, } \\
\text { percent }\end{array}$} & 56.5 & 3.5 & 6.2 & \multirow{2}{*}{$\begin{array}{l}\text { Highway Research } \\
\text { Board (1962a) }\end{array}$} \\
\hline & 65.4 & 5.3 & 8.1 & \\
\hline & 70.0 & 3.7 & 5.3 & \multirow[t]{5}{*}{ Sherman (1971) } \\
\hline & 85.6 & 2.2 & 2.6 & \\
\hline & 86.8 & 7.5 & 8.6 & \\
\hline & 87.4 & 6.8 & 7.8 & \\
\hline & 89.4 & 4.3 & 4.8 & \\
\hline \multicolumn{5}{|c|}{$\begin{array}{l}\text { Sampling error and experimental error (testing and inherent) accounted for } 30 \text { percent } \\
\text { of the total variance. } \\
2 \text { Sampling error and experimental error (testing and inherent) accounted for } 20 \text { percent } \\
\text { of the total variance. }\end{array}$} \\
\hline
\end{tabular}




\begin{tabular}{|c|c|c|c|}
\hline \multicolumn{4}{|c|}{$\begin{array}{l}\text { Table E6 } \\
\text { Field Compaction, Percent Relative to Laboratory Density }\end{array}$} \\
\hline Mean & $\begin{array}{l}\text { Standard } \\
\text { Deviation } \\
\end{array}$ & $\begin{array}{l}\text { Coefficient of } \\
\text { Variation, Percent } \\
\end{array}$ & Reference \\
\hline 93.1 & 1.6 & 1.7 & \multirow[t]{2}{*}{ Granley (1969)' } \\
\hline 94.2 & 2.9 & 3.1 & \\
\hline 95.3 & 1.2 & 1.3 & \multirow[t]{3}{*}{ Shook $(1966)^{2}$} \\
\hline 95.6 & 1.4 & 1.5 & \\
\hline 96.0 & 1.4 & 1.5 & \\
\hline 96.2 & 1.1 & 1.1 & Mitchell et al. (1977) \\
\hline 96.9 & 1.0 & 1.0 & \multirow[t]{2}{*}{ Highway Research Board (1962a) } \\
\hline 97.0 & 1.5 & 1.5 & \\
\hline 97.6 & 0.6 & $0.6^{3}$ & \multirow{2}{*}{$\begin{array}{l}\text { Kennedy, Hudson, and McCullough } \\
\text { (1975) }\end{array}$} \\
\hline N/A & N/A & $3.7^{4}$ & \\
\hline \multicolumn{4}{|c|}{$\begin{array}{l}\text { Sampling error and experimental error (testing and inherent) accounted for } 35 \text { percent } \\
\text { of the total variance. } \\
2 \text { Sampling error and experimental error (testing and inherent) accounted for } 40 \text { percent } \\
\text { of the total variance. } \\
\text { Airfield. } \\
\text { Highway. } \\
\text { N/A Data not reported. }\end{array}$} \\
\hline
\end{tabular}




\begin{tabular}{|c|c|c|c|c|}
\hline \multicolumn{5}{|c|}{$\begin{array}{l}\text { Table E7 } \\
\text { Measures of Stiffness and Strength }\end{array}$} \\
\hline Measure & Mean & $\begin{array}{l}\text { Standard } \\
\text { Deviation } \\
\end{array}$ & $\begin{array}{l}\text { Coefficient of } \\
\text { Variation, Percent }\end{array}$ & Reference \\
\hline \multirow[t]{2}{*}{$\begin{array}{l}\text { Marshall stability, } \\
\mathrm{kN}\end{array}$} & 9.9 & 1.3 & 13 & $\begin{array}{l}\text { Mitchell et al. } \\
(1977)\end{array}$ \\
\hline & 10.3 & 1.3 & 12 & Granley $(1969)^{1}$ \\
\hline \multirow[t]{2}{*}{ Marshall flow, mm } & 2.2 & 0.3 & 15 & Granley $(1969)^{2}$ \\
\hline & 2.3 & 0.3 & 15 & $\begin{array}{l}\text { Mitchell et al. } \\
(1977)\end{array}$ \\
\hline $\begin{array}{l}\text { Indirect tensile } \\
\text { strength, } \mathrm{kPa}\end{array}$ & 531 & 85 & 16 & $\begin{array}{l}\text { Marshall and } \\
\text { Kennedy (1974) }\end{array}$ \\
\hline \multirow{3}{*}{$\begin{array}{l}\text { Indirect } \\
\text { static modulus, } \\
\mathrm{MPa}\end{array}$} & 289 & 84 & 29 & $\begin{array}{l}\text { Marshall and } \\
\text { Kennedy (1974) }\end{array}$ \\
\hline & 397 & 258 & 65 & \multirow{2}{*}{$\begin{array}{l}\text { Kennedy, Hudson, } \\
\text { and McCullough } \\
\text { (1975) }\end{array}$} \\
\hline & 654 & 477 & 73 & \\
\hline \multirow[t]{2}{*}{$\begin{array}{l}\text { Indirect poisson's } \\
\text { ratio }\end{array}$} & 0.40 & 0.11 & 27 & $\begin{array}{l}\text { Marshall and } \\
\text { Kennedy (1974) }\end{array}$ \\
\hline & N/A & N/A & $\begin{array}{c}52 \\
(38 \text { to } 73)\end{array}$ & $\begin{array}{l}\text { Kennedy, Hudson, } \\
\text { and McCullough } \\
(1975)\end{array}$ \\
\hline $\begin{array}{l}\text { Dynamic modulus } \\
\text { at } 4^{\circ} \mathrm{C}, \mathrm{MPa}\end{array}$ & N/A & N/A & $\begin{array}{l}13 \\
(9.2 \text { to } 16)\end{array}$ & $\begin{array}{l}\text { The Asphalt } \\
\text { Institute (1974) }\end{array}$ \\
\hline \multirow{2}{*}{$\begin{array}{l}\text { Dynamic modulus } \\
\text { at } 21^{\circ} \mathrm{C}, \mathrm{MPa}\end{array}$} & N/A & N/A & $\begin{array}{c}16 \\
(11 \text { to } 19) \\
\end{array}$ & $\begin{array}{l}\text { The Asphalt } \\
\text { Institute (1974) }\end{array}$ \\
\hline & N/A & N/A & $\begin{array}{c}40 \\
(24 \text { to } 62)\end{array}$ & $\begin{array}{l}\text { Kennedy, Hudson, } \\
\text { and McCullough } \\
(1975)\end{array}$ \\
\hline $\begin{array}{l}\text { Dynamic modulus } \\
\text { at } 38^{\circ} \mathrm{C}, \mathrm{MPa} \\
\end{array}$ & N/A & N/A & $\begin{array}{c}22 \\
(21 \text { to } 23) \\
\end{array}$ & $\begin{array}{l}\text { The Asphalt } \\
\text { Institute (1974) }\end{array}$ \\
\hline \multicolumn{5}{|c|}{$\begin{array}{l}\text { Sampling error and experimental error (testing and inherent) accounted for } 60 \text { percent of } \\
\text { the total variance. } \\
2 \text { Sampling error and experimental error (testing and inherent) accounted for } 75 \text { percent of } \\
\text { the total variance. } \\
\text { N/A Data not reported. }\end{array}$} \\
\hline
\end{tabular}




\begin{tabular}{|c|c|c|c|c|}
\hline \multicolumn{5}{|c|}{$\begin{array}{l}\text { Table E8 } \\
\text { Flexural Properties of Asphalt Concrete }\end{array}$} \\
\hline Property & Mean & $\begin{array}{l}\text { Standard } \\
\text { Deviation } \\
\end{array}$ & $\begin{array}{l}\text { Coefficient of } \\
\text { Variation, Percent }\end{array}$ & Reference \\
\hline \multirow{3}{*}{$\begin{array}{l}\text { Flexural stiffness } \\
\text { at } 4^{\circ} \mathrm{C}, \mathrm{Mpa}\end{array}$} & 3,972 & 517 & 13 & Finn $(1967)^{\prime}$ \\
\hline & 4,627 & 1,020 & 22 & Finn $(1967)^{2}$ \\
\hline & 4,909 & 979 & 20 & $\begin{array}{l}\text { Monismith et al. } \\
(1967)^{2}\end{array}$ \\
\hline \multirow{4}{*}{$\begin{array}{l}\text { Flexural stiffness } \\
\text { at } 21^{\circ} \mathrm{C}, \mathrm{MPa}\end{array}$} & 889 & 152 & 17 & Finn $(1967)^{\prime}$ \\
\hline & N/A & N/A & 13 & $\begin{array}{l}\text { Monismith et al. } \\
(1967)^{\prime}\end{array}$ \\
\hline & 1,048 & 283 & 27 & $\begin{array}{l}\text { Monismith et al. } \\
(1967)^{2}\end{array}$ \\
\hline & 1.089 & 276 & 25 & Finn $(1967)^{2}$ \\
\hline $\begin{array}{l}\text { Fatigue life at } \\
21^{\circ} \mathrm{C} \text {, cycles } \\
\end{array}$ & N/A & N/A & $\begin{array}{l}65 \\
(23 \text { to } 135) \\
\end{array}$ & $\begin{array}{l}\text { Monismith et al. } \\
(1970)^{3}\end{array}$ \\
\hline \multicolumn{5}{|c|}{$\begin{array}{l}\text { Laboratory-compacted samples. } \\
2 \text { Field samples. } \\
\text { Controlled stress. } \\
\text { N/A Data not reported. }\end{array}$} \\
\hline
\end{tabular}




\begin{tabular}{|c|c|c|c|}
\hline \multicolumn{4}{|c|}{$\begin{array}{l}\text { Table E9 } \\
\text { Mat Thickness } \\
\end{array}$} \\
\hline Mean, mm & $\begin{array}{l}\text { Standard } \\
\text { Deviation } \\
\end{array}$ & $\begin{array}{l}\text { Coefficient of } \\
\text { Variation, Percent } \\
\end{array}$ & Reference \\
\hline 66 & 5.6 & 8.4 & \multirow[t]{2}{*}{ Attoh-Okine and Roddis (1994) } \\
\hline 71 & 6.6 & 9.3 & \\
\hline 79 & 12 & 15 & Keyser and Waell $(1968)^{\prime}$ \\
\hline 112 & 5.6 & 5.0 & Attoh-Okine and Roddis (1994) \\
\hline N/A & 6.6 & N/A & Granley (1969) \\
\hline N/A & 10 & N/A & Huculak (1968) \\
\hline N/A & 10 & N/A & Sherman (1971) \\
\hline N/A & N/A & 2.7 to 5.9 & Yoder and Witczak $(1975)^{2}$ \\
\hline N/A & N/A & 3.5 to 19.2 & Yoder and Witczak $(1975)^{3}$ \\
\hline N/A & N/A & 22 & Yoder and Witczak $(1975)^{4}$ \\
\hline \multicolumn{4}{|c|}{$\begin{array}{l}\text { 1. Frequency distributions appeared to be normal in shape. } \\
2 \text { New airfield. } \\
3 \text { New highway. } \\
4 \text { Overlay. } \\
\text { N/A Data not reported. }\end{array}$} \\
\hline
\end{tabular}

\section{Table E10 \\ Benkelman Beam Deflections, mm}

\begin{tabular}{|c|c|c|c|}
\hline Mean & $\begin{array}{l}\text { Standard } \\
\text { Deviation } \\
\end{array}$ & $\begin{array}{l}\text { Coefficient of } \\
\text { Variation, Percent } \\
\end{array}$ & Reference \\
\hline 2.6 & 1.8 & 69 & \multirow[t]{3}{*}{ Kerr and Parkes (1966) } \\
\hline 3.2 & 1.3 & 41 & \\
\hline 3.6 & 1.7 & 47 & \\
\hline N/A & N/A & 15 & C.G.R.A. $(1962)^{2}$ \\
\hline N/A & N/A & 22 & C.G.R.A. $(1962)^{3}$ \\
\hline \multicolumn{4}{|c|}{$\begin{array}{l}\text { Frequency distributions appeared to have a positive skew. } \\
2 \text { WASHO Road Test. } \\
3 \text { State highways. } \\
\text { N/A Data not reported. }\end{array}$} \\
\hline
\end{tabular}




\begin{tabular}{|c|c|c|c|c|}
\hline \multicolumn{5}{|c|}{$\begin{array}{l}\text { Table E11 } \\
\text { Falling Weight Deflectometer Results }\end{array}$} \\
\hline Measure & Mean & $\begin{array}{l}\text { Standard } \\
\text { Deviation } \\
\end{array}$ & $\begin{array}{l}\text { Coefficient of } \\
\text { Variation, } \\
\text { Percent } \\
\end{array}$ & Reference \\
\hline \multirow{8}{*}{$\begin{array}{l}\text { Deflections under } \\
\text { load, } \mu \mathrm{m}\end{array}$} & 182 & 30 & 16 & \multirow{2}{*}{$\begin{array}{l}\text { Siddharthan, Sebaaly, } \\
\text { and Javaregowda } \\
(1992)^{\prime}\end{array}$} \\
\hline & 212 & 28 & 13 & \\
\hline & 728 & 124 & 17 & \multirow[t]{2}{*}{ Grogan (1991) } \\
\hline & 1.082 & 341 & 32 & \\
\hline & 1,293 & 153 & 12 & \multirow{2}{*}{$\begin{array}{l}\text { Siddharthan, Sebaaly, } \\
\text { and Javaregowda } \\
(1992)^{\prime}\end{array}$} \\
\hline & 1,303 & 158 & 12 & \\
\hline & 1,307 & 81 & 6.2 & \multirow{2}{*}{ Grogan (1991) } \\
\hline & 1,473 & 287 & 20 & \\
\hline \multirow{4}{*}{$\begin{array}{l}\text { Deflections at } \\
0.9 \mathrm{~m} \text { offset, } \mu \mathrm{m}\end{array}$} & 55 & 7.9 & 14 & \multirow{4}{*}{$\begin{array}{l}\text { Siddharthan, Sebaaly, } \\
\text { and Javaregowda } \\
(1992)^{\prime}\end{array}$} \\
\hline & 60 & 11 & 18 & \\
\hline & 173 & 29 & 17 & \\
\hline & 174 & 26 & 15 & \\
\hline \multirow{8}{*}{$\begin{array}{l}\text { Backcalculated } \\
\text { moduli for asphalt } \\
\text { concrete, } \mathrm{MPa}\end{array}$} & 227 & 211 & 93 & \multirow[t]{4}{*}{ Grogan (1991) } \\
\hline & 690 & 207 & 30 & \\
\hline & 1,074 & 483 & 45 & \\
\hline & 1,616 & 582 & 36 & \\
\hline & 1,848 & 1,076 & 58 & \multirow{4}{*}{$\begin{array}{l}\text { Siddharthan, Sebaaly, } \\
\text { and Javaregowda } \\
(1992)^{2}\end{array}$} \\
\hline & 2,034 & 1,020 & 50 & \\
\hline & 5,109 & 1.841 & 36 & \\
\hline & 9,991 & 3.454 & 35 & \\
\hline \multirow{6}{*}{$\begin{array}{l}\text { Backcalculated } \\
\text { moduli for base } \\
\text { course, Mpa }\end{array}$} & 96.2 & 21 & 22 & Grogan (1991) \\
\hline & 110 & 47 & 42 & \multirow{2}{*}{$\begin{array}{l}\text { Siddharthan, Sebaaly, } \\
\text { and Javaregowda } \\
(1992)^{2}\end{array}$} \\
\hline & 128 & 66 & 51 & \\
\hline & 207 & 27 & 13 & \multirow[t]{3}{*}{ Grogan (1991) } \\
\hline & 242 & 244 & 101 & \\
\hline & 401 & 180 & 45 & \\
\hline & & & & (Continued) \\
\hline
\end{tabular}




\begin{tabular}{|c|c|c|c|c|}
\hline Measure & Mean & $\begin{array}{l}\text { Standard } \\
\text { Deviation }\end{array}$ & $\begin{array}{l}\text { Coefficient of } \\
\text { Variation, } \\
\text { Percent } \\
\end{array}$ & Reference \\
\hline \multirow{2}{*}{$\begin{array}{l}\text { Backcalculated } \\
\text { moduli for base } \\
\text { course, Mpa }\end{array}$} & 505 & 123 & 24 & \multirow{2}{*}{$\begin{array}{l}\text { Siddharthan, Sebaaly, } \\
\text { and Javaregowda } \\
(1992)^{2}\end{array}$} \\
\hline & 539 & 171 & 32 & \\
\hline \multirow{8}{*}{$\begin{array}{l}\text { Backcalculated } \\
\text { moduli for } \\
\text { subgrade, } \mathrm{MPa}\end{array}$} & 37 & 2.3 & 6.3 & \multirow{3}{*}{$\begin{array}{l}\text { Siddharthan, Sebaaly, } \\
\text { and Javaregowda } \\
(1992)^{2}\end{array}$} \\
\hline & 38 & 2.1 & 5.3 & \\
\hline & 110 & 12 & 11 & \\
\hline & 119 & 17 & 14 & \multirow[t]{2}{*}{ Grogan (1991) } \\
\hline & 142 & 16 & 11 & \\
\hline & 146 & 14 & 10 & $\begin{array}{l}\text { Siddharthan, Sebaaly, } \\
\text { and Javaregowda } \\
(1992)^{2}\end{array}$ \\
\hline & 435 & 35 & 8.0 & \multirow[t]{2}{*}{ Grogan (1991) } \\
\hline & 483 & 116 & 24 & \\
\hline
\end{tabular}

\section{Table E12}

Initial Serviceability Index

\begin{tabular}{||l|l|l|l||}
\hline \hline Mean & $\begin{array}{l}\text { Standard } \\
\text { Deviation }\end{array}$ & $\begin{array}{l}\text { Coefficient of } \\
\text { Variation, Percent }\end{array}$ & Reference \\
\hline \hline 4.2 & 0.33 & 7.9 & Darter, Hudson, and Brown (1973)' \\
\hline \hline \multicolumn{3}{|l}{ 'Normality was not rejected by the chi-square "goodness-of-fit" test. } \\
\hline
\end{tabular}




\section{Appendix $F$ Portland Cement Concrete}




\begin{tabular}{|c|c|c|c|}
\hline \multicolumn{4}{|c|}{$\begin{array}{l}\text { Table F1 } \\
\text { Air Content (Percent) of Concrete in its Plastic State }\end{array}$} \\
\hline Mean & $\begin{array}{l}\text { Standard } \\
\text { Deviation } \\
\end{array}$ & $\begin{array}{l}\text { Coefficient of } \\
\text { Variation, Percent } \\
\end{array}$ & Reference \\
\hline 4.4 & 0.7 & 16 & Hanna, McLaughlin, and Lott (1967) \\
\hline 4.6 & 0.8 & 17 & Neamen and Laquros (1967) \\
\hline 4.6 & 0.8 & 18 & \multirow[t]{2}{*}{ Newion (1966) } \\
\hline 4.8 & 0.7 & 14 & \\
\hline 4.8 & 0.6 & 13 & Brown (1975) \\
\hline 5.0 & 0.8 & 16 & Baker and McMahon (1969) \\
\hline 5.4 & 0.8 & 15 & Willenbrock $(1974 b)^{\prime}$ \\
\hline 5.4 & 1.0 & 19 & SRCWV (1968) \\
\hline 5.5 & 0.8 & 15 & \multirow[t]{2}{*}{ Baker and McMahon (1969) } \\
\hline 6.5 & 1.4 & 22 & \\
\hline $\begin{array}{l}\text { Frequ } \\
\text { Note: } \\
\text { accoun } \\
\text { McLaus }\end{array}$ & $\begin{array}{l}\text { tribution } \\
\text { verage, sa } \\
5 \text { percent } \\
\text { Lott } 196 \\
\end{array}$ & $\begin{array}{l}\text { eared to have negati } \\
\text { ling error and experin } \\
\text { the total variance (Ba } \\
\text { SRCWV } 1968 ; \text { Neam }\end{array}$ & $\begin{array}{l}\text { skew. } \\
\text { ntal error (testing and inherent) } \\
\text { er and McMahon 1969; Hanna, } \\
\text { and Laquros 1967). }\end{array}$ \\
\hline
\end{tabular}

\begin{tabular}{|c|c|c|c|}
\hline \multicolumn{4}{|c|}{$\begin{array}{l}\text { Table F2 } \\
\text { Slump }(\mathrm{mm}) \text { of Concrete in its Plastic State }\end{array}$} \\
\hline Mean & $\begin{array}{l}\text { Standard } \\
\text { Deviation } \\
\end{array}$ & $\begin{array}{l}\text { Coefficient of } \\
\text { Variation, Percent }\end{array}$ & Reference \\
\hline 38 & 8 & 20 & Willenbrock (1979b)' \\
\hline 38 & 20 & 53 & Neamen and Laquros (1967) \\
\hline 51 & 13 & 25 & Kennedy, Hudson, and McCullough (1975) \\
\hline 51 & 15 & 30 & Brown (1975) \\
\hline 53 & 15 & 28 & \multirow[t]{2}{*}{ Baker and McMahon (1969) } \\
\hline 56 & 18 & 32 & \\
\hline 56 & 18 & 31 & Newion (1966) \\
\hline 61 & 20 & 33 & SRCWV (1968) \\
\hline 76 & 25 & 33 & Newlon (1966) \\
\hline 76 & 25 & 33 & Hanna, McLaughlin, and Lott (1967) \\
\hline \multicolumn{4}{|c|}{$\begin{array}{l}\text { Frequency distribution appeared to be normal in shape. } \\
\text { Note: On the average, sampling error and experimental error (testing and inherent) } \\
\text { accounted for } 20 \text { percent of the total variance (Hanna, McLaughlin, and Lott 1967; } \\
\text { SRCWV 1968; Neamen and Laquros 1967; Baker and McMahon 1969). }\end{array}$} \\
\hline
\end{tabular}




\section{Table F3}

Particle Size Distribution for Concrete Aggregates, Percent Finer

\begin{tabular}{|c|c|c|c|c|}
\hline Sieve Size & Mean & $\begin{array}{l}\text { Standard } \\
\text { Deviation } \\
\end{array}$ & $\begin{array}{l}\text { Coefficient of } \\
\text { Variation, } \\
\text { Percent }\end{array}$ & Reference \\
\hline \multirow[t]{2}{*}{$25 \mathrm{~mm}$} & 95.6 & 3.8 & 4.0 & $\begin{array}{l}\text { Louisiana Department of } \\
\text { Highways (1966) }\end{array}$ \\
\hline & 96.4 & 1.6 & 1.7 & Willenbrock (1974b) ${ }^{1}$ \\
\hline \multirow[t]{4}{*}{$19 \mathrm{~mm}$} & 69.1 & 11.5 & 17 & \multirow[t]{2}{*}{ Baker and McMahon (1969) } \\
\hline & 71.5 & 12.6 & 18 & \\
\hline & 75.4 & 10.8 & 14 & $\begin{array}{l}\text { Louisiana Department of } \\
\text { Highways (1966) }\end{array}$ \\
\hline & 92.6 & 3.5 & 3.8 & Baker and McMahon (1969) \\
\hline \multirow[t]{2}{*}{$13 \mathrm{~mm}$} & 35.5 & 12.7 & 36 & $\begin{array}{l}\text { Louisiana Department of } \\
\text { Highways }(1966)\end{array}$ \\
\hline & 39.9 & 6.7 & 17 & Willenbrock (1974b) \\
\hline \multirow[t]{2}{*}{$4.75 \mathrm{~mm}$} & 1.3 & 1.2 & 92 & $\begin{array}{l}\text { Louisiana Department of } \\
\text { Highways (1966) }\end{array}$ \\
\hline & 2.4 & 1.1 & 46 & Willenbrock $(1974 b)^{1}$ \\
\hline 2.36 & 1.4 & 0.9 & 64 & Willenbrock (1974b) \\
\hline \multirow[t]{2}{*}{$4.75 \mathrm{~mm}$} & 96.2 & 1.1 & 1.1 & Willenbrock $(1974 b)^{1}$ \\
\hline & 97.8 & 1.5 & 1.5 & $\begin{array}{l}\text { Louisiana Department of } \\
\text { Highways (1966) }\end{array}$ \\
\hline $2.36 \mathrm{~mm}$ & 79.4 & 2.5 & 3.1 & Willenbrock $(1974 b)^{1}$ \\
\hline $1.18 \mathrm{~mm}$ & 64.9 & 3.9 & 6.0 & Willenbrock (1974b)' \\
\hline $0.60 \mathrm{~mm}$ & 48.1 & 4.2 & 8.7 & Willenbrock $(1974 b)^{1}$ \\
\hline \multirow[t]{2}{*}{$0.30 \mathrm{~mm}$} & 15.9 & 6.5 & 41 & $\begin{array}{l}\text { Louisiana Department of } \\
\text { Highways (1966) }\end{array}$ \\
\hline & 20.6 & 2.7 & 13 & Willenbrock $(1974 b)^{1}$ \\
\hline \multirow[t]{2}{*}{$0.15 \mathrm{~mm}$} & 2.1 & 1.3 & 62 & $\begin{array}{l}\text { Louisiana Department of } \\
\text { Highways (1966) }\end{array}$ \\
\hline & 3.9 & 0.7 & 18 & Willenbrock $(1974 b)^{1}$ \\
\hline \multicolumn{5}{|c|}{$\begin{array}{l}\text { Frequency distribution appeared to be normal in shape. } \\
\text { Note: Sampling error and experimental error (testing and inherent) accounted for the } \\
\text { following percentages of total variance. } \\
-25-\mathrm{mm} \text { sieve: } 30 \text { percent (Louisiana Department of Highways 1966). } \\
\text { - } 19-\mathrm{mm} \text { sieve: } 40 \text { percent (Baker and McMahon 1969; LA Department of Highways 1966). } \\
-13-\mathrm{mm} \text { sieve: } 85 \text { percent (Louisiana Department of Highways 1966). } \\
\text { - } 4.75-\mathrm{mm} \text { sieve: } 50 \text { percent (Louisiana Department of Highways 1966). } \\
\text { Note: Sampling error and experimental error (testing and inherent) accounted for the } \\
\text { following percentages of total variance (Louisiana Department of Highways 1966). } \\
-4.75-\mathrm{mm} \text { sieve: } 15 \text { percent. } \\
-1.18-\mathrm{mm} \text { sieve: } 8 \text { percent. } \\
-0.15-\mathrm{mm} \text { sieve: } 20 \text { percent. }\end{array}$} \\
\hline
\end{tabular}




\begin{tabular}{|c|c|c|c|}
\hline \multicolumn{4}{|c|}{$\begin{array}{l}\text { Table F4 } \\
\text { Fineness Modulus of Concrete Aggregates }\end{array}$} \\
\hline Mean & $\begin{array}{l}\text { Standard } \\
\text { Deviation } \\
\end{array}$ & $\begin{array}{l}\text { Coefficient of } \\
\text { Variation, Percent }\end{array}$ & Reference \\
\hline 2.86 & 0.12 & 4.2 & Willenbrock (1974b)' \\
\hline
\end{tabular}

\begin{tabular}{|c|c|c|c|}
\hline \multicolumn{4}{|c|}{$\begin{array}{l}\text { Table F5 } \\
\text { Density of Hardened Concrete, } \mathrm{kg} / \mathrm{m}^{3}\end{array}$} \\
\hline Mean & $\begin{array}{l}\text { Standard } \\
\text { Deviation }\end{array}$ & \begin{tabular}{|l} 
Coefficient of \\
Variation, Percent \\
\end{tabular} & Reference \\
\hline 2,371 & 14.3 & 0.6 & Hanna, McLaughlin, and Lott (1967) \\
\hline N/A & N/A & $\begin{array}{l}2.1 \\
(1.3 \text { to } 2.4) \\
\end{array}$ & $\begin{array}{l}\text { Kennedy, Hudson, and McCullough } \\
\text { (1975) }\end{array}$ \\
\hline N/A & N/A & $\begin{array}{l}1.7 \\
(1.1 \text { to } 4.7)\end{array}$ & Marshall and Kennedy (1974) \\
\hline
\end{tabular}




\begin{tabular}{|c|c|c|c|}
\hline \multicolumn{4}{|c|}{$\begin{array}{l}\text { Table F6 } \\
\text { Compressive Strength of Hardened Concrete, MPa }\end{array}$} \\
\hline Mean & $\begin{array}{l}\text { Standard } \\
\text { Deviation }\end{array}$ & $\begin{array}{l}\text { Coefficient of } \\
\text { Variation, Percent }\end{array}$ & Reference \\
\hline 20 & 5.5 & 28 & Highway Research Board (1962a) \\
\hline 26 & 5.0 & 19 & Neamen and Laquros (1967) \\
\hline 26 & 2.0 & 7.6 & Highway Research Board (1962a) \\
\hline 26 & 4.1 & 16 & \multirow[t]{2}{*}{ SRCWV (1966) } \\
\hline 26 & 2.8 & 11 & \\
\hline 27 & 4.9 & 18 & \multirow{4}{*}{$\begin{array}{l}\text { State Road Depaartment of Florida } \\
(1965)\end{array}$} \\
\hline 28 & 3.9 & 14 & \\
\hline 28 & 4.2 & 15 & \\
\hline 29 & 4.6 & 16 & \\
\hline 29 & 3.8 & 13 & Newlon (1966) \\
\hline 29 & 2.5 & 8.6 & Highway Research Board (1962a) \\
\hline 31 & 3.5 & 12 & \multirow[t]{2}{*}{ Newlon (1966) } \\
\hline 31 & 4.6 & 15 & \\
\hline 32 & 3.9 & 12 & \multirow[t]{3}{*}{ SRCWV (1966) } \\
\hline 32 & 5.5 & 17 & \\
\hline 33 & 3.3 & 10 & \\
\hline 33 & 2.7 & 8.0 & Willenbrock (1974a)' \\
\hline 33 & 4.0 & 12 & \multirow{2}{*}{$\begin{array}{l}\text { State Road Depaartment of Florida } \\
(1965)\end{array}$} \\
\hline 34 & 4.7 & 14 & \\
\hline 34 & 3.7 & 11 & Highway Research Board (1962a) \\
\hline 35 & 4.2 & 12 & \multirow{2}{*}{$\begin{array}{l}\text { State Road Depaartment of Florida } \\
\text { (1965) }\end{array}$} \\
\hline 35 & 4.6 & 13 & \\
\hline 40 & 2.8 & 6.9 & $\begin{array}{l}\text { Kennedy, Hudson, and McCullough } \\
(1975)\end{array}$ \\
\hline 42 & 2.6 & 6.1 & Highway Research Board (1962a) \\
\hline $\begin{array}{l}\text { Freq } \\
\text { Note: } \\
\text { accoun } \\
1966 \text {; }\end{array}$ & $\begin{array}{l}y \text { distribut } \\
\text { he averag } \\
\text { for } 45 \text { per }\end{array}$ & $\begin{array}{l}\text { peared to be norma } \\
\text { pling error and expe } \\
\text { the total variance }\end{array}$ & $\begin{array}{l}\text { in shape. } \\
\text { imental error (testing and inherent) } \\
\text { Neamen and Laquros 1967; Newlon }\end{array}$ \\
\hline
\end{tabular}




\begin{tabular}{||l|l|l|l|l||}
\hline \hline \multicolumn{5}{||l||}{$\begin{array}{l}\text { Table F7 } \\
\text { Compressive Modulus and Poisson's Ratio for Hardened Concrete }\end{array}$} \\
\hline \hline \multirow{2}{*}{\begin{tabular}{l} 
Property \\
\hline \hline $\begin{array}{l}\text { Compression } \\
\text { Modulus, MPa }\end{array}$
\end{tabular}} & Mean & $\begin{array}{l}\text { Standard } \\
\text { Deviation }\end{array}$ & $\begin{array}{l}\text { Coefficient of } \\
\text { Variation, Percent }\end{array}$ & Reference \\
\cline { 2 - 6 } & N/A & 6,189 & 24 & $\begin{array}{l}\text { Marshall and } \\
\text { Kennedy (1974) }\end{array}$ \\
\hline & N/A & $\begin{array}{l}34 \\
(21 \text { to 49) }\end{array}$ & $\begin{array}{l}\text { Kennedy, Hudson, } \\
\text { and McCullough } \\
\text { (1975) }\end{array}$ \\
\hline Poisson's ratio & N/A & N/A & $\begin{array}{l}14 \\
(9.4 \text { to 20) }\end{array}$ & Gibeaut (1960) \\
\hline \hline N/A Data not reported.
\end{tabular}

\begin{tabular}{|c|c|c|c|c|}
\hline \multicolumn{5}{|c|}{$\begin{array}{l}\text { Table F8 } \\
\text { Measures of Tensile Stiffness and Strength }\end{array}$} \\
\hline Measure & Mean & $\begin{array}{l}\text { Standard } \\
\text { Deviation } \\
\end{array}$ & $\begin{array}{l}\text { Coefficient of } \\
\text { Variation, } \\
\text { Percent } \\
\end{array}$ & Reference \\
\hline \multirow[t]{3}{*}{$\begin{array}{l}\text { Indirect tensile } \\
\text { strength, } \mathrm{kPa}\end{array}$} & 3,248 & 648 & 20 & $\begin{array}{l}\text { Marshall and Kennedy } \\
\text { (1974) }\end{array}$ \\
\hline & 3,806 & 269 & 7.0 & \multirow{2}{*}{$\begin{array}{l}\text { Kennedy, Hudson, and } \\
\text { McCullough (1975)' }\end{array}$} \\
\hline & 4,399 & 793 & 18 & \\
\hline \multirow[t]{2}{*}{$\begin{array}{l}\text { Indirect tensile } \\
\text { modulus, MPa }\end{array}$} & 23,788 & 8,067 & 34 & $\begin{array}{l}\text { Kennedy, Hudson, and } \\
\text { McCullough (1975)' }\end{array}$ \\
\hline & 27,511 & 9,377 & 34 & $\begin{array}{l}\text { Marshall and Kennedy } \\
(1974)\end{array}$ \\
\hline \multirow{7}{*}{$\begin{array}{l}\text { Flexural } \\
\text { strength, } \mathrm{kPa}\end{array}$} & 3,792 & 255 & 6.7 & \multirow{2}{*}{$\begin{array}{l}\text { Highway Research } \\
\text { Board (1962a) }\end{array}$} \\
\hline & 4,344 & 241. & 5.6 & \\
\hline & 4,461 & 359 & 8.0 & $\begin{array}{l}\text { Kennedy, Hudson, and } \\
\text { McCullough (1975) }\end{array}$ \\
\hline & 4,564 & 434 & 9.5 & Brown (1975) \\
\hline & 4,895 & 365 & 7.5 & $\begin{array}{l}\text { Highway Research } \\
\text { Board (1962a) }\end{array}$ \\
\hline & 5,282 & 421 & 8.0 & Brown (1975) \\
\hline & 6,068 & 365 & 6.0 & $\begin{array}{l}\text { Highway Research } \\
\text { Board (1962a) } \\
\end{array}$ \\
\hline
\end{tabular}




\begin{tabular}{|c|c|c|c|}
\hline \multicolumn{4}{|c|}{$\begin{array}{l}\text { Table F9 } \\
\text { Slab Thickness, } \mathrm{mm}\end{array}$} \\
\hline Mean & $\begin{array}{l}\text { Standard } \\
\text { Deviation }\end{array}$ & $\begin{array}{l}\text { Coefficient of } \\
\text { Variation, Percent }\end{array}$ & Reference \\
\hline 211 & 7.6 & 3.6 & $\begin{array}{l}\text { Louisiana Department of Highways } \\
(1966)\end{array}$ \\
\hline 211 & 6.1 & 2.9 & Marshall and Kennedy (1974) \\
\hline 216 & 7.6 & 3.5 & $\begin{array}{l}\text { Oklahoma Department of Highways } \\
(1968)\end{array}$ \\
\hline 226 & 2.5 & 1.1 & Neamen and Laquros (1967) \\
\hline 226 & 2.5 & 1.1 & \multirow{2}{*}{$\begin{array}{l}\text { Oklahoma Department of Highways } \\
\text { (1968) }\end{array}$} \\
\hline 229 & 10 & 4.4 & \\
\hline 234 & 7.1 & 3.0 & $\begin{array}{l}\text { Michigan Department of Highways } \\
(1966)^{\prime}\end{array}$ \\
\hline 234 & 7.4 & 3.2 & $\begin{array}{l}\text { Louisiana Department of Highways } \\
(1966)\end{array}$ \\
\hline 241 & 11 & 4.7 & Marshall and Kennedy (1974) \\
\hline 262 & 6.9 & 2.6 & $\begin{array}{l}\text { Louisiana Department of Highways } \\
(1966)\end{array}$ \\
\hline 277 & 23 & 8.3 & \multirow{2}{*}{$\begin{array}{l}\text { Kennedy, Hudson, and McCullough } \\
\text { (1975) }\end{array}$} \\
\hline 376 & 12 & 3.3 & \\
\hline
\end{tabular}




\begin{tabular}{|c|c|c|c|c|}
\hline \multicolumn{5}{|c|}{$\begin{array}{l}\text { Table F10 } \\
\text { Load Transfer (Percent) }\end{array}$} \\
\hline Joint Type & Mean & $\begin{array}{l}\text { Standard } \\
\text { Deviation } \\
\end{array}$ & $\begin{array}{l}\text { Coefficient of } \\
\text { Variation, } \\
\text { Percent } \\
\end{array}$ & Reference \\
\hline $\begin{array}{l}\text { Doweled } \\
\text { expansion }\end{array}$ & 30.5 & 7.4 & 24 & Rollings (1987) \\
\hline \multirow{6}{*}{$\begin{array}{l}\text { Doweled } \\
\text { construction }\end{array}$} & $12.2^{1}$ & 3.6 & 29 & \multirow{5}{*}{$\begin{array}{l}\text { Hammons, Pittman, and } \\
\text { Mathews }(1995)^{3}\end{array}$} \\
\hline & $15.5^{\prime}$ & 5.8 & 38 & \\
\hline & $16.3^{2}$ & 4.1 & 25 & \\
\hline & $19.3^{1}$ & 1.8 & 9.3 & \\
\hline & $28.5^{2}$ & 4.6 & 16 & \\
\hline & 30.6 & 11.6 & 38 & Rollings (1987) \\
\hline $\begin{array}{l}\text { Keyed } \\
\text { construction }\end{array}$ & 25.4 & 10.5 & 41 & Rollings (1987) \\
\hline \multirow{6}{*}{$\begin{array}{l}\text { Doweled } \\
\text { contraction }\end{array}$} & $13.0^{\prime}$ & 6.6 & 50 & \multirow{6}{*}{$\begin{array}{l}\text { Hammons, Pittman, and } \\
\text { Mathews }(1995)^{3}\end{array}$} \\
\hline & $16.3^{1}$ & 9.1 & 56 & \\
\hline & $17.9^{1}$ & 3.9 & 22 & \\
\hline & $21.2^{\prime}$ & 2.1 & 9.9 & \\
\hline & $26.6^{2}$ & 3.1 & 12 & \\
\hline & $30.7^{2}$ & 1.1 & 3.5 & \\
\hline \multirow{3}{*}{$\begin{array}{l}\text { Tied } \\
\text { contraction }\end{array}$} & $24.7^{2}$ & 8.6 & 35 & \multirow{3}{*}{$\begin{array}{l}\text { Hammons, Pittman, and } \\
\text { Mathews }(1995)^{4}\end{array}$} \\
\hline & $25.5^{\prime}$ & 1.8 & 6.9 & \\
\hline & $27.0^{\prime}$ & 4.3 & 16 & \\
\hline \multirow{10}{*}{$\begin{array}{l}\text { Plain } \\
\text { contraction }\end{array}$} & $6.4^{1}$ & 2.9 & 46 & \multirow{10}{*}{$\begin{array}{l}\text { Hammons, Pittman, and } \\
\text { Mathews }(1995)^{3}\end{array}$} \\
\hline & $9.0^{1}$ & 7.4 & 82 & \\
\hline & $10.6^{2}$ & 3.2 & 30 & \\
\hline & $10.8^{2}$ & 3.2 & 30 & \\
\hline & $11.9^{1}$ & 2.0 & 17 & \\
\hline & $11.9^{1}$ & 3.4 & 29 & \\
\hline & $12.8^{2}$ & 1.6 & 13 & \\
\hline & $13.6^{2}$ & 1.6 & 12 & \\
\hline & $14.2^{2}$ & 3.7 & 26 & \\
\hline & $17.4^{\prime}$ & 6.6 & 38 & \\
\hline & & & & Con \\
\hline \multicolumn{5}{|c|}{$\begin{array}{l}\text { Cold testing conditions. } \\
2 \text { Warm testing conditions. } \\
3 \text { Frequency distribution appeared to have positive skew. } \\
4 \text { Frequency distribution appeared to be normal in shape. } \\
\end{array}$} \\
\hline
\end{tabular}




\begin{tabular}{|c|c|c|c|c|}
\hline Joint Type & Mean & $\begin{array}{l}\text { Standard } \\
\text { Deviation } \\
\end{array}$ & $\begin{array}{l}\text { Coefficient of } \\
\text { Variation, } \\
\text { Percent }\end{array}$ & Reference \\
\hline \multirow{10}{*}{$\begin{array}{l}\text { Plain } \\
\text { contraction } \\
\text { (Cont.) }\end{array}$} & $17.4^{2}$ & 3.4 & 19 & \multirow{9}{*}{$\begin{array}{l}\text { Hammons, Pittman, and } \\
\text { Mathews }(1995)^{3}\end{array}$} \\
\hline & $17.5^{\prime}$ & 4.3 & 25 & \\
\hline & $17.6^{2}$ & 2.2 & 13 & \\
\hline & $17.6^{1}$ & 5.3 & 30 & \\
\hline & $20.0^{2}$ & 3.1 & 16 & \\
\hline & $20.3^{2}$ & 5.5 & 27 & \\
\hline & $20.4^{1}$ & 6.7 & 33 & \\
\hline & $20.8^{\prime}$ & 2.6 & 12 & \\
\hline & $25.2^{2}$ & 2.2 & 8.7 & \\
\hline & 37.2 & 7.1 & 19 & Rollings (1987) \\
\hline
\end{tabular}

\section{Table F11}

Falling Weight Deflectometer Results

\begin{tabular}{|c|c|c|c|c|}
\hline Measure & Mean & $\begin{array}{l}\text { Standard } \\
\text { Deviation }\end{array}$ & $\begin{array}{l}\text { Coefficient of } \\
\text { Variation, Percent }\end{array}$ & Reference \\
\hline \multirow{4}{*}{$\begin{array}{l}\text { Deflections under load, } \\
\mu \mathrm{m}\end{array}$} & 81 & 8.9 & 11 & \multirow{9}{*}{$\begin{array}{l}\text { Grogan } \\
\text { (1991) }\end{array}$} \\
\hline & 102 & 2.9 & 2.8 & \\
\hline & 396 & 45 & 11 & \\
\hline & 4,53 & 121 & 27 & \\
\hline \multirow{2}{*}{$\begin{array}{l}\text { Backcalculated moduli } \\
\text { for portland cement } \\
\text { concrete, MPa }\end{array}$} & 25,690 & 2,830 & 11 & \\
\hline & 29,150 & 15,740 & 54 & \\
\hline \multirow{3}{*}{$\begin{array}{l}\text { Backcalculated moduli } \\
\text { for subgrade, } \mathrm{MPa}\end{array}$} & 80 & 14 & 17 & \\
\hline & 109 & 17 & 16 & \\
\hline & 167 & 32 & 19 & \\
\hline
\end{tabular}

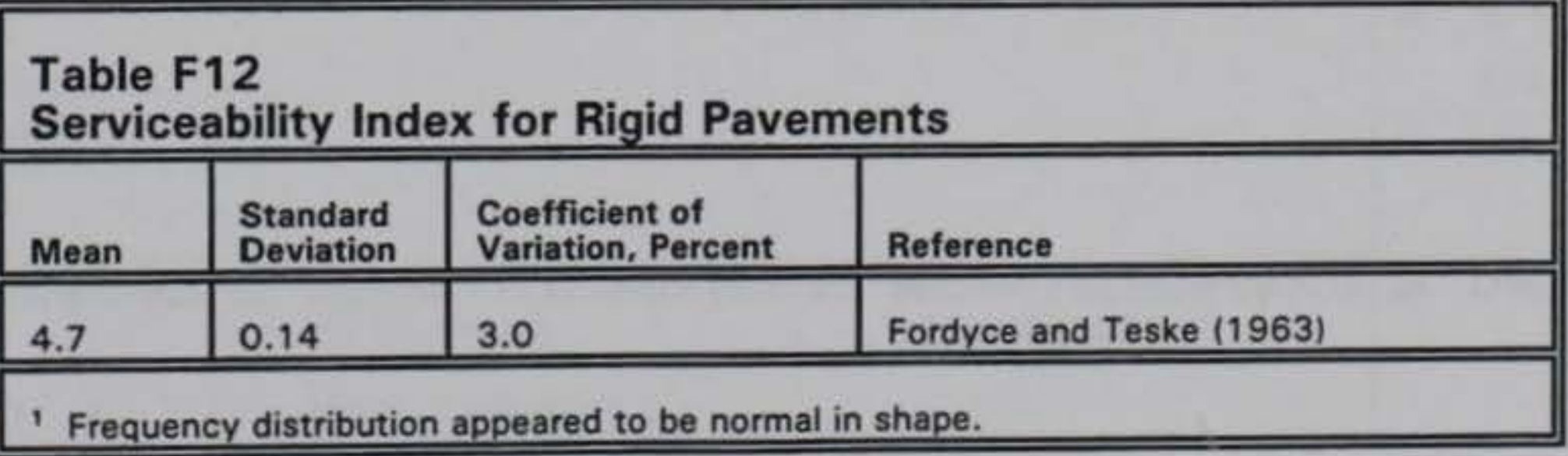




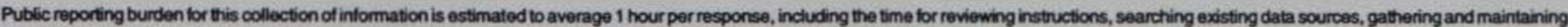

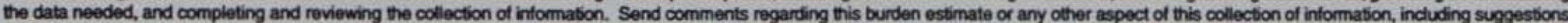

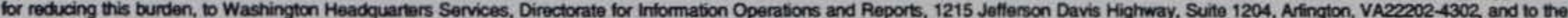
Olfice of Management and Budget, Paperwork Reduction Project (0704-0188). Washington, DC20503.
1. AGENCY USE ONLY (Leave blank)
2. REPORT DATE
August 1997
3. REPORT TYPE AND DATES COVERED
Final report

4. TITLE AND SUBTITLE

5. FUNDING NUMBERS

Statistical Analysis and Variability of Pavement Materials

6. AUTHOR(S)

Reed B. Freeman, William P. Grogan

7. PERFORMING ORGANIZATION NAME(S) AND ADDRESS(ES)

U.S. Army Engineer Waterways Experiment Station

3909 Halls Ferry Road, Vicksburg, MS 39180-6199

8. PERFORMING ORGANIZATION REPORT NUMBER

Technical Report GL-97-12

9. SPONSORING/MONITORING AGENCY NAME(S) AND ADDRESS(ES)

U.S. Army Corps of Engineers

10. SPONSORING/MONITORING AGENCY REPORT NUMBER

Washington, DC 20314-1000

\section{SUPPLEMENTARY NOTES}

Available from National Technical Information Service, 5285 Port Royal Road, Springfield, VA 22161.

12a. DISTRIBUTIONAVAILABILITY STATEMENT

Approved for public release; distribution is unlimited.

12b. DISTRIBUTION CODE

\section{ABSTRACT (Maximum 200 words)}

This report provides a summary of published data concerning the variability of pavement materials and structures. In addition, related statistical concepts and data analysis techniques are reviewed. This study was initiated as the first step toward the development of statistical specifications for pavement construction.

14. SUBJECT TERMS

Pavement materials

Statistical analysis

Variability
15. NUMBER OF PAGES

170

16. PRICE CODE
17. SECURITY CLASSIFICATION OF REPORT

UNCLASSIFIED
18. SECURITY CLASSIFICATION OF THIS PAGE

UNCLASSIFIED
19. SECURITY CLASSIFICATION OF ABSTRACT
Standard Form 298 (Rev. 2-89)

Prescribed by ANSI Sto. Z39-18 298-10e 